Prepared in cooperation with the U.S. Department of Energy, National Nuclear Security Administration Nevada Site Office, Office of Environmental Management under Interagency Agreement DE-A152-07NA28100

\title{
Transient Effects on Groundwater Chemical Compositions from Pumping of Supply Wells at the Nevada National Security Site, Nye County, Nevada, 1951-2008
}

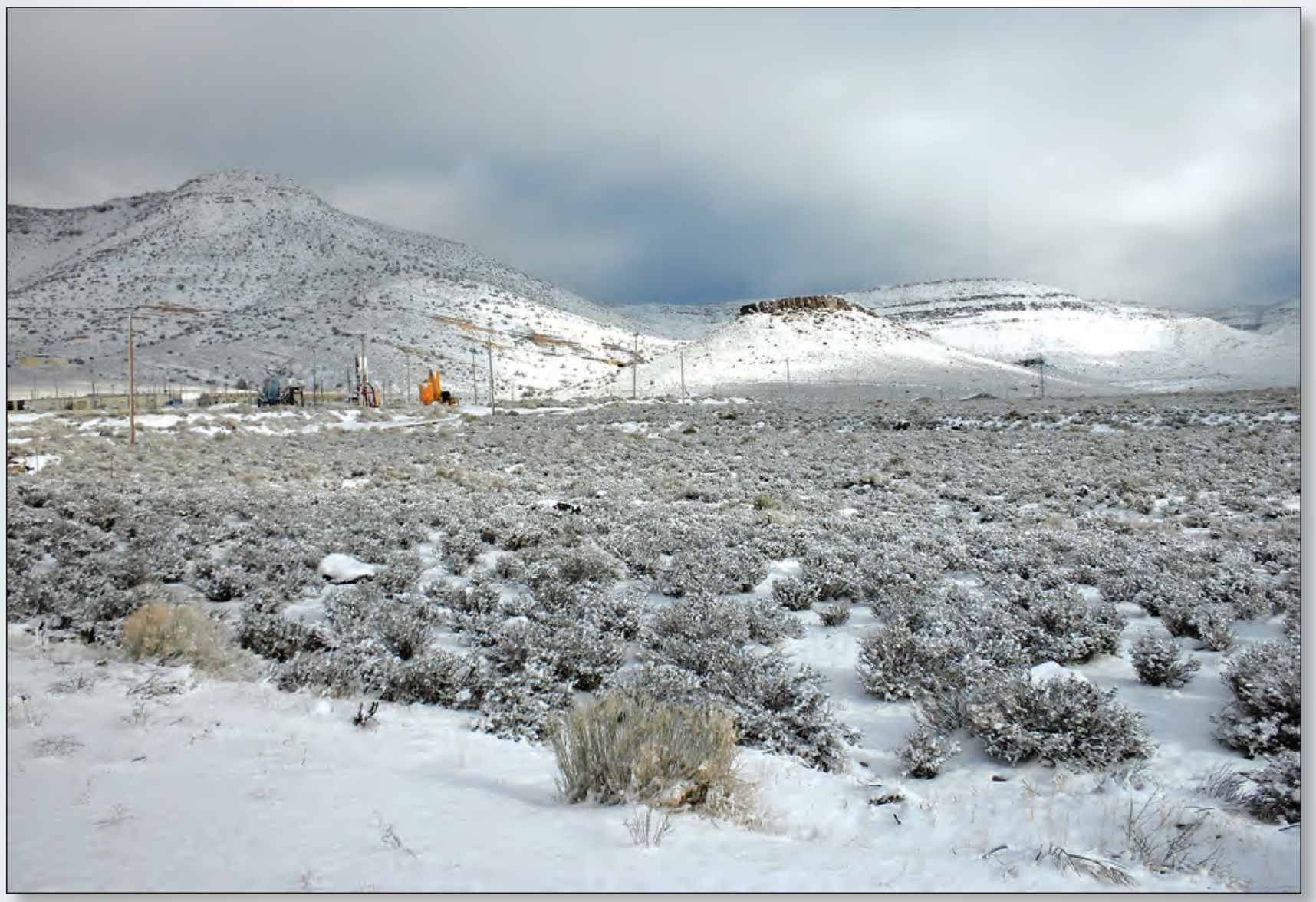

Scientific Investigations Report 2012-5023 
Cover: Photograph looking northwest toward Survey Butte and Rainier Mesa in administrative area 12 of the Nevada National Security Site after a March snow storm. (Photograph taken by Rodney L. Munson, U.S. Geological Survey, 2011.) 


\section{Transient Effects on Groundwater Chemical Compositions from Pumping of Supply Wells at the Nevada National Security Site, Nye County, Nevada, 1951-2008}

By James B. Paces, Peggy E. Elliott, Joseph M. Fenelon, Randell J. Laczniak, and Michael T. Moreo

Prepared in cooperation with the U.S. Department of Energy, National

Nuclear Security Administration Nevada Site Office, Office of Environmental

Management under Interagency Agreement DE-A152-07NA28100

Scientific Investigations Report 2012-5023 


\title{
U.S. Department of the Interior \\ KEN SALAZAR, Secretary \\ U.S. Geological Survey \\ Marcia K. McNutt, Director
}

\author{
U.S. Geological Survey, Reston, Virginia: 2012
}

For more information on the USGS - the Federal source for science about the Earth, its natural and living resources, natural hazards, and the environment, visit http://www.usgs.gov or call 1-888-ASK-USGS.

For an overview of USGS information products, including maps, imagery, and publications, visit http://www.usgs.gov/pubprod

To order this and other USGS information products, visit http://store.usgs.gov

Any use of trade, product, or firm names is for descriptive purposes only and does not imply endorsement by the U.S. Government.

Although this report is in the public domain, permission must be secured from the individual copyright owners to reproduce any copyrighted materials contained within this report.

Suggested citation:

Paces, J.B., Elliott, P.E., Fenelon, J.M., Laczniak, R.J., and Moreo, M.T., 2012, Transient effects on groundwater chemical compositions from pumping of supply wells at the Nevada National Security Site, 1951-2008: U.S.

Geological Survey Scientific Investigations Report 2012-5023, 108 p. 


\section{Contents}

Abstract

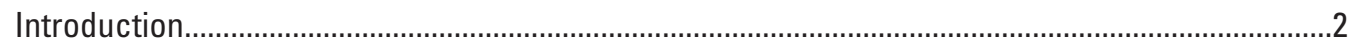

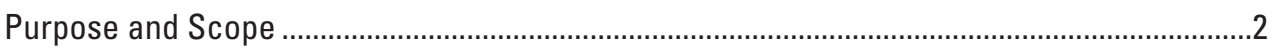

Description of Study Area ..............................................................................................

Supply Wells on the Nevada National Security Site............................................................

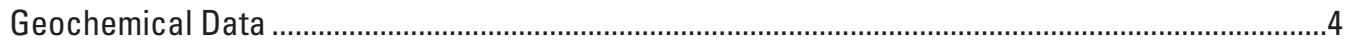

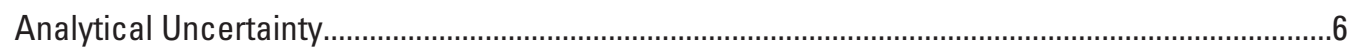

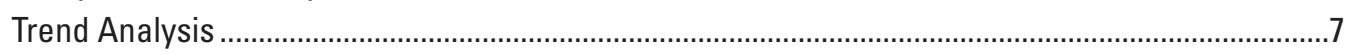

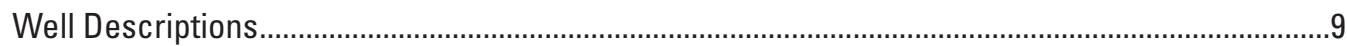

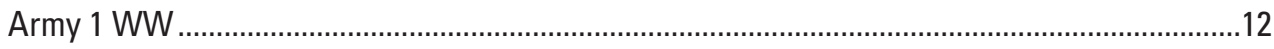

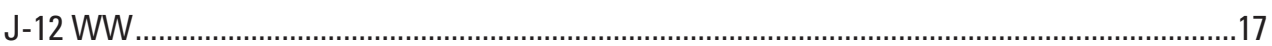

J-13 WW

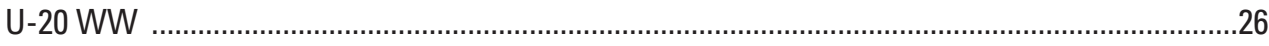

UE-5c WW

UE-15d WW

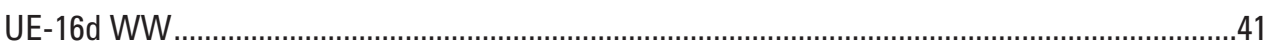

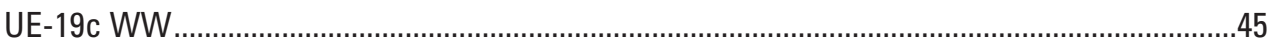

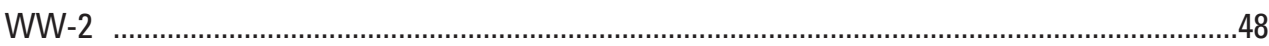

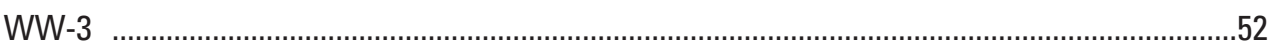

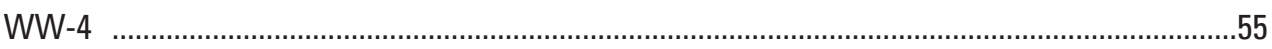

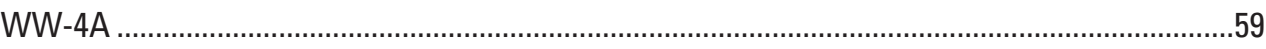

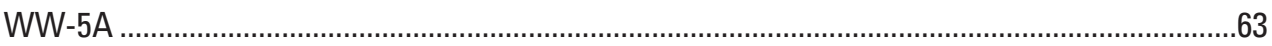

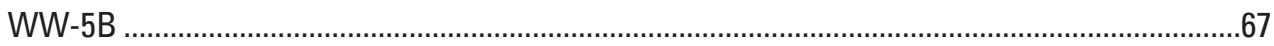

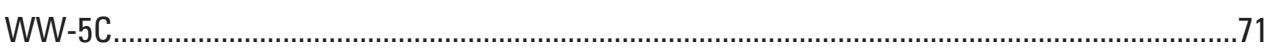

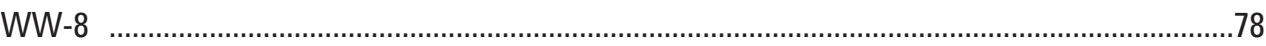

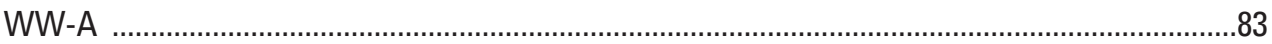

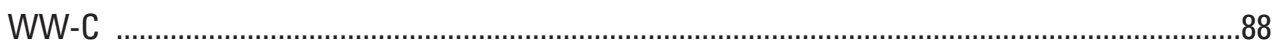

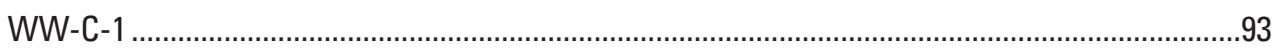

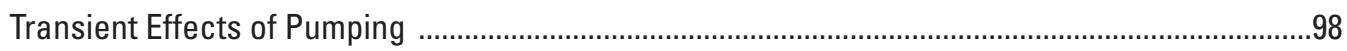

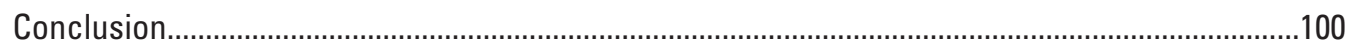

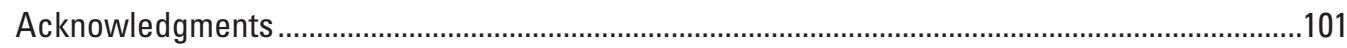

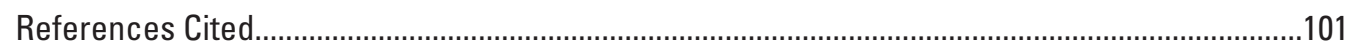

Appendix A. pH and Specific Conductance Data for Water from Supply Wells at the Nevada National Security Site, Nye County, Nevada, 1951-2008......................................105

Appendix B. Major Ion Concentration Data for Water from Supply Wells at the Nevada National Security Site, Nye County, Nevada, 1951-2008 ……...........................................105

Appendix C. Trace Element Concentration and Environmental Isotope Data for Water From Supply Wells at the Nevada National Security Site, Nye County, Nevada, 1951-2008 ....106

Appendix D. Results of Normality Tests and Trend Analyses...................................................107

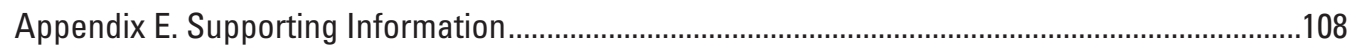

Appendix F. Median and Mean Concentrations for Major lons in Water from Supply

Wells at the Nevada National Security Site, Nye County, Nevada. 


\section{Figures}

Figure 1. Shaded relief map showing locations of boreholes used for water supply on the Nevada National Security Site, Nye County, Nevada

Figure 2. Trilinear plots of major ion concentrations grouped by wells and hydrostratigraphic units in samples from water-supply wells on the Nevada National Security Site, Nye County, Nevada

Figure 3. Graphs showing temporal variations in specific conductance for water samples collected from Army 1 WW, Nevada National Security Site, Nye County, Nevada ....

Figure 4. Graphs showing temporal variations in major-ion concentrations for water samples collected from Army 1 WW, Nevada National Security Site, Nye County, Nevada ....

Figure 5. Graph showing isotopic compositions of hydrogen and oxygen for water sampled from Army $1 \mathrm{WW}$ and data from other water-supply wells at the Nevada National Security Site, Nye County, Nevada

Figure 6. Graphs showing temporal variations in specific conductance for water samples collected from J-12 WW, Nevada National Security Site, Nye County, Nevada

Figure 7. Graphs showing temporal variations in major-ion concentrations for water samples collected from J-12 WW, Nevada National Security Site, Nye County, Nevada

Figure 8. Graph showing isotopic compositions of hydrogen and oxygen for water samples collected from J-12 WW and J-13 WW and data from other water-supply wells at the Nevada National Security Site, Nye County, Nevada ... 20

Figure 9. Graphs showing temporal variations in specific conductance for water samples collected from J-13 WW, Nevada National Security Site, Nye County, Nevada

Figure 10. Graphs showing temporal variations in major-ion concentrations for water samples collected from J-13 WW, Nevada National Security Site, Nye County, Nevada

Figure 11. Graphs showing temporal variations in concentration and isotopic compositions of strontium (Sr) and uranium (U), and correlations between $\mathrm{Sr}$ and $\mathrm{U}$ isotope ratios in water samples collected from J-13 WW, Nevada National Security Site, Nye County, Nevada

Figure 12. Graphs showing temporal variations in specific conductance for water samples collected from U-20 WW, Nevada National Security Site, Nye County, Nevada

Figure 13. Graphs showing temporal variations in major-ion concentrations for water samples collected from U-20 WW, Nevada National Security Site, Nye County, Nevada

Figure 14. Graph showing isotopic compositions of hydrogen and oxygen for water samples collected from U-20 WW, UE-19c WW, and WW-8 and data from other water-supply wells at the Nevada National Security Site, Nye County, Nevada ... 29

Figure 15. Graph showing temporal variations in strontium isotopic compositions of water samples collected from U-20 WW (cased), Nevada National Security Site, Nye County, Nevada

Figure 16. Graphs showing temporal variations in specific conductance for water samples collected from UE-5c WW, Nevada National Security Site, Nye County, Nevada 


\section{Figures-Continued}

Figure 17. Graphs showing temporal variations in major-ion concentrations for water samples collected from UE-5c WW, Nevada National Security Site, Nye County, Nevada

Figure 18. Graph showing temporal variations in arsenic concentration for water samples collected from UE-5c WW, Nevada National Security Site, Nye County, Nevada

Figure 19. Graph showing isotopic compositions of hydrogen and oxygen for water samples collected from UE-5c WW and data from other water-supply wells at the Nevada National Security Site, Nye County, Nevada

Figure 20. Graphs showing temporal variations in specific conductance for water samples collected from UE-15d WW, Nevada National Security Site, Nye County, Nevada

Figure 21. Graphs showing temporal variations in major-ion concentrations for water samples collected from UE-15d WW, Nevada National Security Site, Nye County, Nevada

Figure 22. Graph showing isotopic compositions of hydrogen and oxygen for water samples from UE-15d WW, UE-16d WW, and WW-2 in Yucca Flat, and data from other water-supply wells at the Nevada National Security Site, Nye County, Nevada

Figure 23. Graphs showing temporal variations in specific conductance for water samples collected from UE-16d WW, Nevada National Security Site, Nye County, Nevada

Figure 24. Graphs showing temporal variations in major-ion concentrations for water samples collected from UE-16d WW, Nevada National Security Site, Nye County, Nevada

Figure 25. Graphs showing temporal variations in specific conductance for water samples collected from UE-19c WW, Nevada National Security Site, Nye County, Nevada

Figure 26. Graphs showing temporal variations in major-ion concentrations for water samples collected from UE-19c WW, Nevada National Security Site, Nye County, Nevada

Figure 27. Graphs showing temporal variations in specific conductance for water samples collected from WW-2, Nevada National Security Site, Nye County, Nevada

Figure 28. Graphs showing temporal variations in major-ion concentrations for water samples collected from WW-2, Nevada National Security Site, Nye County, Nevada

Figure 29. Graph showing temporal variations in specific conductance for water samples collected from WW-3, Nevada National Security Site, Nye County, Nevada

Figure 30. Graphs showing temporal variations in major-ion concentrations for water samples collected from WW-3, Nevada National Security Site, Nye County, Nevada

Figure 31. Graphs showing temporal variations in specific conductance for water samples collected from WW-4, Nevada National Security Site, Nye County, Nevada

Figure 32. Graphs showing temporal variations in major-ion concentrations for water samples collected from WW-4, Nevada National Security Site, Nye County, Nevada 


\section{Figures-Continued}

Figure 33. Graph showing isotopic compositions of hydrogen and oxygen for water samples from WW-4 and WW-4A in northern Frenchman Flat, and data from other water-supply wells at the Nevada National Security Site, Nye County, Nevada

Figure 34. Graph showing temporal variations in specific conductance for water samples collected from WW-4A, Nevada National Security Site, Nye County, Nevada ..... 59

Figure 35. Graphs showing temporal variations in major-ion concentrations for water samples collected from WW-4A, Nevada National Security Site, Nye County, Nevada

Figure 36. Graph showing concentration ratios for water samples collected on the same day from both WW-4 and WW-4A, Nevada National Security Site, Nye County, Nevada

Figure 37. Graph showing temporal variations in specific conductance for water samples collected from WW-5A, Nevada National Security Site, Nye County, Nevada 64

Figure 38. Graphs showing temporal variations in major-ion concentrations for water samples collected from WW-5A, Nevada National Security Site, Nye County, Nevada

Figure 39. Graph showing isotopic compositions of hydrogen and oxygen for water samples from WW-5A, WW-5B, and WW-5C in central Frenchman Flat, and data from other water-supply wells at the Nevada National Security Site, Nye County, Nevada

Figure 40. Graphs showing temporal variations in specific conductance for water samples collected from WW-5B, Nevada National Security Site, Nye County, Nevada

Figure 41. Graphs showing temporal variations in major-ion concentrations for water samples collected from WW-5B, Nevada National Security Site, Nye County, Nevada

Figure 42. Graph showing temporal variations in uranium concentration for water samples collected from WW-5B, Nevada National Security Site, Nye County, Nevada

Figure 43. Graphs showing temporal variations in specific conductance for water samples collected from WW-5C, Nevada National Security Site, Nye County, Nevada

Figure 44. Graphs showing temporal variations in major-ion concentrations for water samples collected from WW-5C, Nevada National Security Site, Nye County, Nevada

Figure 45. Graphs showing relations between total annual water withdrawn from WW-5C and bicarbonate $\left(\mathrm{HCO}_{3}\right)$ concentrations for samples collected within a given water year, and chloride and total alkalinity as $\mathrm{HCO}_{3}$ for water samples collected from WW-5C, Nevada National Security Site, Nye County, Nevada

Figure 46. Graphs showing temporal variations in uranium and arsenic concentrations for water samples collected from WW-5C, Nevada National Security Site, Nye County, Nevada .....

Figure 47. Graphs showing temporal variations in specific conductance for water samples collected from WW-8, Nevada National Security Site, Nye County, Nevada 


\section{Figures-Continued}

Figure 48. Graphs showing temporal variations in major-ion concentrations for water samples collected from WW-8, Nevada National Security Site, Nye County, Nevada

Figure 49. Graphs showing temporal variations in lithium and uranium concentrations for water samples collected from WW-8, Nevada National Security Site, Nye County, Nevada

Figure 50. Graphs showing temporal variations in specific conductance for water samples collected from WW-A, Nevada National Security Site, Nye County, Nevada

Figure 51. Graphs showing temporal variations in major-ion concentrations for water samples collected from WW-A, Nevada National Security Site, Nye County, Nevada

Figure 52. Graph showing isotopic compositions of hydrogen and oxygen for water samples from WW-A, WW-C, and WW-C-1 in southern Yucca Flat, and data from other water-supply wells from the Nevada National Security Site, Nye County, Nevada

Figure 53. Graphs showing temporal variations in specific conductance for water samples collected from WW-C, Nevada National Security Site, Nye County, Nevada

Figure 54. Graphs showing temporal variations in major-ion concentrations for water samples collected from WW-C, Nevada National Security Site, Nye County, Nevada

Figure 55. Graph showing deviation of selected trace element concentrations from mean values for water samples collected from WW-C, Nevada National Security Site, Nye County, Nevada

Figure 56. Graph showing median values for major ion concentrations, most reliably determined trace element concentrations, and environmental isotopes reported for water samples collected from WW-C-1 normalized to median values for the same constituents from WW-C, Nevada National Security Site, Nye County, Nevada

Figure 57. Graphs showing temporal variations in specific conductance for water samples collected from WW-C-1, Nevada National Security Site, Nye County, Nevada

Figure 58. Graphs showing temporal variations in major-ion concentrations for water samples collected from WW-C-1, Nevada National Security Site, Nye County, Nevada

Figure 59. Graph showing deviation of selected trace element concentrations from mean values for water samples collected from WW-C-1, Nevada National Security Site, Nye County, Nevada 


\section{Tables}

Table 1. Locations, depths, and total groundwater withdrawals for supply wells on the Nevada National Security Site, Nye County, Nevada, 1951-2008

Table 2. Results of trend analyses for major constituents in water pumped from Army 1 WW, Nevada National Security Site, Nye County, Nevada, between July 10, 1962, and July 13, 2005

Table 3. Results of trend analyses for major constituents in water pumped from J-12 WW, Nevada National Security Site, Nye County, Nevada, between April 25, 1958, and July 25, 2006

Table 4. Results of trend analyses for major constituents in water pumped from J-13 WW, Nevada National Security Site, Nye County, Nevada, between January 1963 and October 2005

Table 5. Results of trend analyses for major constituents in water pumped from U-20 WW, Nevada National Security Site, Nye County, Nevada, between May 23, 1987, and November 5, 1997

Table 6. Results of trend analyses for major constituents in water pumped from UE-5c WW, Nevada National Security Site, Nye County, Nevada, between March 23, 1971, and January 28, 2003

Table 7. Results of trend analyses for major constituents in water pumped from UE-15d WW, Nevada National Security Site, Nye County, Nevada, between November 2, 1966, and August 1, 1990

Table 8. Results of trend analyses for major constituents in water pumped from UE-16d WW, Nevada National Security Site, Nye County, Nevada, between January 1, 1981, and July 12, 2005

Table 9. Results of trend analyses for major constituents in water pumped from WW-2, Nevada National Security Site, Nye County, Nevada, between April 25, 1962, and January 30, 1991

Table 10. Results of trend analyses for major constituents in water pumped from WW-3, Nevada National Security Site, Nye County, Nevada, between April 4, 1957, and April 16, 1969

Table 11. Results of trend analyses for major constituents in water pumped from WW-4, Nevada National Security Site, Nye County, Nevada, between December 1, 1981, and July 25, 2006

Table 12. Results of trend analyses for major constituents in water pumped from WW-4A, Nevada National Security Site, Nye County, Nevada, between August 8,2000 , and July 25, 2006

Table 13. Results of trend analyses for major constituents in water pumped from WW-5A, Nevada National Security Site, Nye County, Nevada, between April 4, 1957, and June 4, 1964

Table 14. Results of trend analyses for major constituents in water pumped from WW-5B, Nevada National Security Site, Nye County, Nevada, between April 4, 1957, and July 25, 2006 


\section{Tables-Continued}

Table 15. Results of trend analyses for major constituents in groundwater pumped from WW-5C, Nevada National Security Site, Nye County, Nevada, between April 1, 1957, and July 25, 2006

Table 16. Comparison of chemical and isotopic data from water samples collected in August 2000 from WW-5A, WW-5C, and WW-5B, Nevada National Security Site, Nye County, Nevada

Table 17. Results of trend analyses for major constituents in water pumped from WW-8, Nevada National Security Site, Nye County, Nevada, between January 11, 1963, and July 25, 2006

Table 18. Results of trend analyses for major constituents in water pumped from WW-A, Nevada National Security Site, Nye County, Nevada, between September 21, 1960, and February 16, 1988

Table 19. Results of trend analyses for major constituents in water pumped from WW-C, Nevada National Security Site, Nye County, Nevada, between April 25, 1962, and May 19, 1993

Table 20. Results of trend analyses for major constituents in groundwater pumped from WW-C-1, Nevada National Security Site, Nye County, Nevada, between June 14, 1964, and July 12, 2005 


\title{
Conversion Factors, Datums, Isotope Notation Conventions, Units of Concentration, and Abbreviations and Acronyms
}

\author{
Conversion Factors
}

\begin{tabular}{|c|c|c|}
\hline Multiply & By & To obtain \\
\hline \multicolumn{3}{|c|}{ Length } \\
\hline foot $(\mathrm{ft})$ & 0.3048 & meter (m) \\
\hline mile (mi) & 1.609 & kilometer $(\mathrm{km})$ \\
\hline \multicolumn{3}{|c|}{ Area } \\
\hline square mile $\left(\mathrm{mi}^{2}\right)$ & 2.590 & square kilometer $\left(\mathrm{km}^{2}\right)$ \\
\hline \multicolumn{3}{|c|}{ Volume } \\
\hline gallon (gal) & 0.003785 & cubic meter $\left(\mathrm{m}^{3}\right)$ \\
\hline million gallons (Mgal) & 3,785 & cubic meter $\left(\mathrm{m}^{3}\right)$ \\
\hline
\end{tabular}

Datums

Vertical coordinate information is referenced to the National Geodetic Vertical Datum of 1929 (NGVD29).

Horizontal coordinate information is referenced to the North American Datum of 1927 (NAD27), unless otherwise stated.

Altitude, as used in this report, refers to distance above the vertical datum.

Isotope Notation Conventions

Hydrogen, oxygen, and carbon isotopic compositions are given in delta hydrogen-2 $\left(\delta^{2} \mathrm{H}\right)$, delta oxygen-18 $\left(\delta^{18} 0\right)$, and delta carbon-13 $\left(\delta^{13} \mathrm{C}\right)$ units calculated using the formulas:

$\delta^{2} \mathrm{H}=\left(\left({ }^{2} \mathrm{H} /{ }^{1} \mathrm{H}_{\text {sample }} /{ }^{2} \mathrm{H} /{ }^{1} \mathrm{H}_{\text {vSMOw }}\right)-1\right) \times 1,000$.

$\delta^{18} 0=\left(\left({ }^{18} 0 /{ }^{16} 0_{\text {sample }} /{ }^{18} 0 /{ }^{16} 0_{\text {vSMow }}\right)-1\right) \times 1,000$.

$\left.\delta^{13} \mathrm{C}=\left({ }^{13} \mathrm{C} /{ }^{12} \mathrm{C}_{\text {sample }} /{ }^{13} \mathrm{C} /{ }^{12} \mathrm{C}_{\mathrm{VPDB}}\right)-1\right) \times 1,000$.

Where ${ }^{2} \mathrm{H} /{ }^{1} \mathrm{H}_{\text {VSMOW }}$ and ${ }^{18} \mathrm{O} /{ }^{16} \mathrm{O}_{\text {VSMOW }}$ are the hydrogen and oxygen isotope ratios in the international isotope standard, Vienna Standard Mean Ocean Water (VSMOW), of 0.00015576 and 0.00200520 , respectively, and ${ }^{13} \mathrm{C} /{ }^{12} \mathrm{C}_{\mathrm{VPDB}}$ is the carbon isotope ratio in the Vienna Pee Dee Belemnite carbonate standard (VPDB) of 0.0112372 . The resulting $\delta^{2} \mathrm{H}, \delta^{18} 0$, and $\delta^{13} \mathrm{C}$ values are in parts per thousand or per mil $(\%)$.

\section{Units of Concentration}

Concentrations of chemical constituents measured in water samples are given either in milligrams of solute per liter of water $(\mathrm{mg} / \mathrm{L}$, equivalent to parts per million in dilute waters such as those reported herein), or in micrograms of solute per liter of water $(\mu \mathrm{g} / \mathrm{L}$, equivalent to parts per billion).

Specific conductance is given in microsiemens per centimeter at 25 degrees Celsius and is abbreviated as $\mu \mathrm{S} / \mathrm{cm}$. 
Conversion Factors, Datums, Isotope Notation Conventions, Units of Concentration, and Abbreviations and AcronymsContinued

Abbreviations and Acronyms

Chemical Symbols

\begin{tabular}{cl}
\hline Abbreviation & Chemical species \\
\hline $\mathrm{As}$ & Arsenic \\
$\mathrm{B}$ & Boron \\
$\mathrm{Ba}$ & Barium \\
$\mathrm{Be}$ & Beryllium \\
$\mathrm{Br}$ & Bromine \\
$\mathrm{Ca}$ & Calcium \\
$\mathrm{Cd}$ & Cadmium \\
$\mathrm{Cl}$ & Chloride \\
$\mathrm{Co}$ & Cobalt \\
$\mathrm{CO}$ & Carbonate \\
$\mathrm{Cr}$ & Chromium \\
$\mathrm{F}$ & Fluoride \\
$\mathrm{Fe}$ & Iron \\
$\mathrm{HCO}$ & Bicarbonate \\
$\mathrm{Hg}$ & Mercury \\
$\mathrm{K}$ & Potassium \\
$\mathrm{Li}$ & Lithium \\
$\mathrm{Mg}$ & Magnesium \\
$\mathrm{Mn}$ & Manganese \\
$\mathrm{Mo}$ & Molybdenum \\
$\mathrm{Na}$ & Sodium \\
$\mathrm{Ni}$ & Nickel \\
$\mathrm{NO}{ }_{3}$ & Nitrate \\
$\mathrm{Pb}$ & Lead \\
$\mathrm{PO}$ & Phosphate \\
$\mathrm{Rb}$ & Rubidium \\
$\mathrm{Sb}_{\mathrm{Se}}$ & Antimony \\
$\mathrm{Se}$ & Selenium \\
$\mathrm{SiO}{ }_{2}$ & Silicon dioxide, or silica \\
$\mathrm{SO}_{4}$ & Sulfate \\
$\mathrm{Sr}$ & Strontium \\
$\mathrm{U}$ & Uranium \\
$\mathrm{V}$ & Vanadium \\
$\mathrm{Zn}$ & Zinc \\
& \\
\hline &
\end{tabular}


This page intentionally left blank. 


\title{
Transient Effects on Groundwater Chemical Compositions from Pumping of Supply Wells at the Nevada National Security Site, Nye County, Nevada, 1951-2008
}

\author{
By James B. Paces, Peggy E. Elliott, Joseph M. Fenelon, Randell J. Laczniak, and Michael T. Moreo
}

\section{Abstract}

Nuclear testing and support activities at the Nevada National Security Site have required large amounts of water for construction, public consumption, drilling, fire protection, hydraulic and nuclear testing, and dust control. To supply this demand, approximately 20,000 million gallons of water have been pumped from 23 wells completed in 19 boreholes located across the Nevada National Security Site starting as early as the 1950s. As a consequence of more or less continuous pumping from many of these wells for periods as long as 58 years, transient groundwater flow conditions have been created in the aquifers that supplied the water. To evaluate whether long-term pumping caused changes in water compositions over time, available chemical analyses of water samples from these 19 boreholes were compiled, screened, and evaluated for variability including statistically significant temporal trends that can be compared to records of groundwater pumping.

Data used in this report have been extracted from a large database (Geochem08, revision 3.0, released in September 2008) containing geochemical and isotopic information created and maintained by primary contractors to the U.S. Department of Energy, National Nuclear Security Administration, Nevada Site Office. Data extracted from this source were compiled for the entire period of record, converted to uniform reporting units, and screened to eliminate analyses of poor or unknown quality, as well as clearly spurious values. The resulting data are included in accompanying spreadsheets that give values for (1) $\mathrm{pH}$ and specific conductance, (2) major ion concentrations, (3) trace element concentrations and environmental isotope ratios, and (4) mean, median, and variance estimates for major ion concentrations.

The resulting data vary widely in quality and time-series density. An effort has been made to establish reasonable ranges of analytical uncertainty expected for each analyte and eliminate analyses that are obvious outliers. Analysis of chemical trends in this report primarily rely on specific conductance measurements and major ion concentrations, data considered to be the most accurate and reliable over the entire time span of investigation. The analysis uses parametric and nonparametric evaluations to provide a statistical basis for trend identification. Trace element and isotope data are examined for consistency, but typically are too inaccurate or infrequent to provide a reliable long term basis for trend evaluation. Groundwater withdrawal records compiled in a companion report are included graphically in this report to allow qualitative comparisons between water quality and pumping history.

Data for each supply well include (1) a borehole description and summary of pumping history, (2) a description of water-quality parameters, (3) an evaluation of temporal variations of specific conductance and major ion concentrations, and (4) an examination of supporting information from trace element and isotope data. A range of responses are observed for individual supply wells that likely include the effects of both aquifer dynamics and changing borehole conditions. Data from most wells show little or no evidence for temporal variation in water-quality parameters indicating that aquifers at the Nevada National Security Site are capable of producing large volumes of compositionally uniform water over many years of pumping. A smaller number of wells show evidence of transient changes. Wells that have ceased pumping commonly show compositions that shift toward lower concentrations in subsequent bailed samples, which indicates that more dilute water entered the well over time due to either leakage of meteoric water into the well casing or more wide-spread recharge into the shallow phreatic zone. Wells that show systematic changes in water compositions during episodes of pumping commonly have multiple open intervals whose contributions to water in the well may change over time due to hydraulic conditions or well dynamics. 


\section{Introduction}

The Nevada National Security Site (NNSS) consists of about 1,350 $\mathrm{mi}^{2}$ in southern Nevada. The NNSS has been used as the primary site for underground testing of nuclear devices by the United States since the late 1950s, initially by the Atomic Energy Commission, and after 1977, by the U.S. Department of Energy (DOE). Development of groundwater resources on the NNSS began in 1951 in response to construction, consumption, and nuclear and hydrologic testing. Since then, more than 25,000 million gallons (Mgal) of water have been pumped from 42 wells having known total withdrawals of more than $5 \mathrm{Mgal}$ and penetrating various aquifers (Elliott and Moreo, 2011). Approximately 78 percent of this water has been pumped from 23 completed water-supply wells in 19 boreholes scattered across the site (fig. 1).

Urban and agricultural development in southern Nevada continues to put pressures on available water resources. Ultimately, an understanding of the transient effects of long term groundwater pumping will contribute to evaluations of the potential for radionuclide transport away from underground test areas on the NNSS under pumping induced conditions. An understanding of these types of aquifer responses is especially relevant if groundwater resources in areas adjacent to the NNSS are more extensively developed in the future.

\section{Purpose and Scope}

Evaluations of water-quality data in this report focused primarily on specific conductance and major ion concentrations from 23 wells completed in 19 boreholes on the NNSS. These wells were pumped extensively over time spans ranging from 18 to 58 years. Analyses of these constituents were available from most supply wells throughout the entire period of pumping. Available trace metal concentrations and environmental isotope compositions are included; however, erratic coverage, high detection limits, and large analytical uncertainties for older data reduce their usefulness for evaluating long-term compositional trends. Analyses of samples collected since the mid-1990s commonly include a larger suite of more-accurately determined constituents.

The chemical data included in this report were not originally collected for the purpose of evaluating long term trends, and the quality of data obtained from numerous laboratories spanning many decades is of concern. Therefore, trends identified in this report are based on substantial shifts in multiple constituents rather than subtle changes in one or two components, especially those at low concentration where analytical accuracy is more questionable. In addition to evaluating temporal trends in existing water-quality samples, data compiled in this report provide a coherent, well-screened baseline for future studies of compositional variation in many of the same wells that continue to be pumped for water supply.

\section{Description of Study Area}

Supply wells evaluated in this study are in or adjacent to five main geographic areas: Pahute Mesa, Yucca Flat, Frenchman Flat, Fortymile Wash, and Mercury Valley (fig. 1). Depths to water in the supply wells are substantial, ranging from about $670 \mathrm{ft}$ to more than 2,300 ft. Supply wells penetrate numerous aquifers. Carbonate-rock aquifers dominate in the eastern part of the study area beneath Yucca Flat, Frenchman Flat, and Mercury Valley, whereas volcanic-rock aquifers dominate in the west beneath Pahute Mesa and Fortymile Wash (Sweetkind and others, 2004). Structural basins filled with Holocene to Pliocene sediments can also form important alluvial aquifers.

At a regional scale, groundwater flows through bedrock aquifers from recharge areas at high elevations within and north of the NNSS, toward discharge areas at low elevations in the south (Winograd and Thordarson, 1975; Fenelon and others, 2010). Three separate groundwater subbasins, named after their downgradient discharge areas (Ash Meadows, Oasis Valley, Alkali Flat-Furnace Creek Ranch), have been identified within the NNSS (Waddell and others, 1984; Laczniak and others, 1996; D’Agnese and others, 2002). Boundaries between these subbasins are poorly constrained, and likely are controlled by complex structural features that juxtapose lithologies constituting the different aquifers and confining units in three dimensions (Sweetkind and others, 2004; Fenelon and others, 2010).

Groundwater tapped by supply wells is derived from various alluvial, volcanic, and carbonate aquifers and composite units. Lithologic units with primary or secondary permeability, including sandy or gravelly alluvium, welded tuffs and lava flows, and carbonate rocks, tend to form aquifers; whereas clay-rich alluvium and playa deposits, altered non-welded tuffs, and siliciclastic rocks commonly form confining units (Winograd and Thordarson, 1975; Laczniak and others, 1996). Hydrostratigraphic units (HSUs) consist of single or multiple contiguous lithologies with similar hydrogeologic characteristics that collectively behave as an identifiable aquifer or confining unit. Designations of HSUs are based on overall hydrologic properties regardless of whether that unit is partially or fully saturated at any given site. A composite geologic framework model for the NNSS forms the basis for classification of different HSUs, which is described in detail by Fenelon and others (2010). 
UNIVERSAL TRANSVERSE MERCATOR-EASTING, ZONE 11, IN METERS

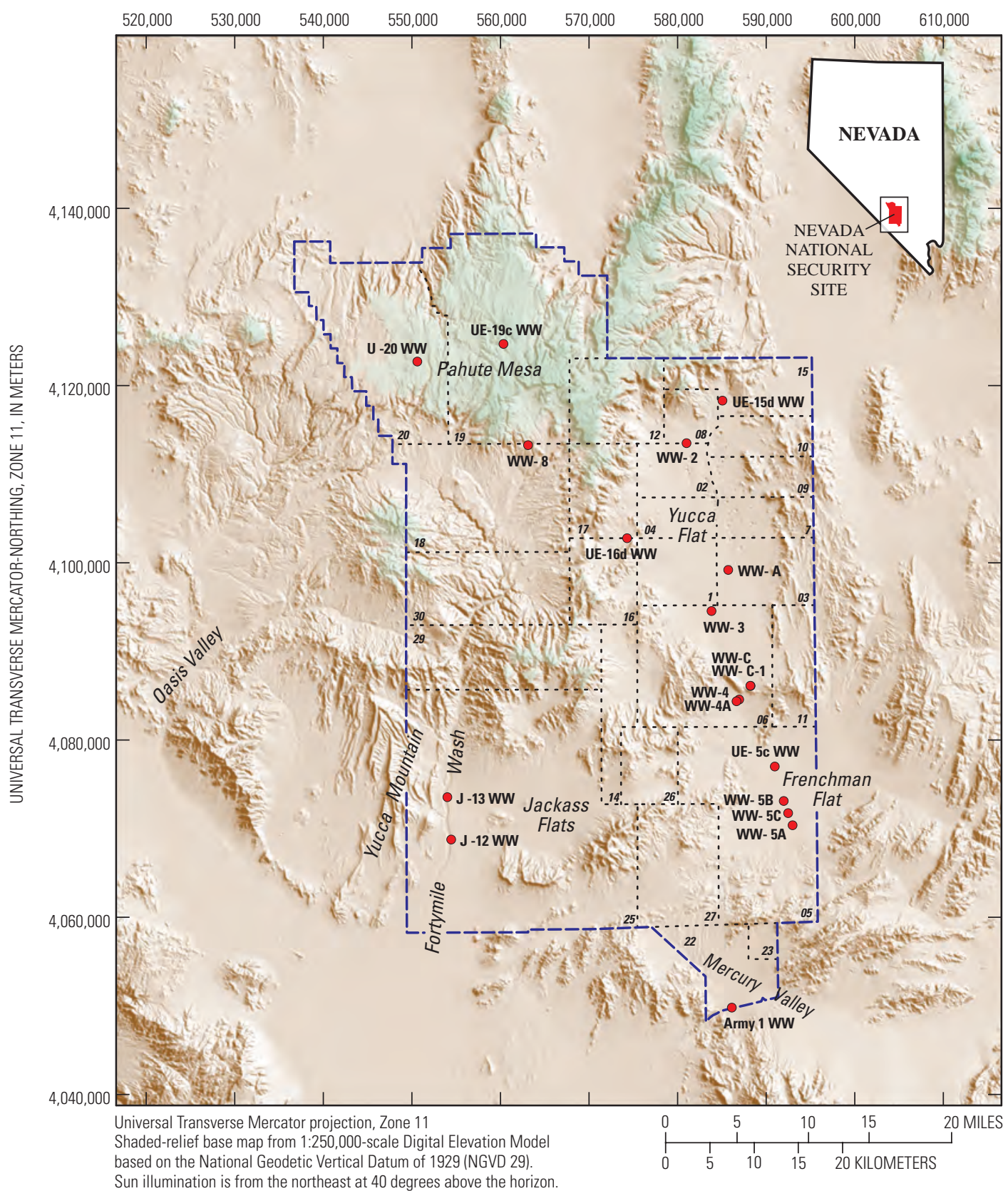

Sun illumination is from the northeast at 40 degrees above the horizon.

Intensity of green shading reflects increasing elevation between 1,500 and 2,900 meters.

\section{EXPLANATION}

\section{- Borehole location}

\section{- - - Nevada National Security Site (NNSS) boundary}

27. . . NNSS administrative area boundary and number

Figure 1. Locations of boreholes used for water supply on the Nevada National Security Site, Nye County, Nevada. 


\section{Supply Wells on the Nevada National Security Site}

Nuclear testing and support operations at the NNSS have required large amounts of water for construction, consumption, drilling, fire protection, hydraulic and nuclear testing, and dust control (U. S. Department of Energy, 2008, p. 2-1, 2-6). Development of the groundwater resource to supply this demand began in 1951 and by 2008, a total of more than 25,000 Mgal of water had been produced from wells on or directly adjacent to the NNSS (Elliott and Moreo, 2011).

Nearly 20,000 Mgal of water were pumped from 19 boreholes (23 unique well completions) (table 1). Total groundwater withdrawals from individual boreholes ranged from 153 to 2,440 Mgal. Of the 23 wells listed in table 1, 8 (as of 2011) are actively pumped to supply water for NNSS activities. These eight supply wells are: $J-12 W W, U E-16 d$ $W W, W W-4, W W-4 A, W W-5 B, W W-5 C, W W-8$ (30-2031 ft), and $W W-C-1$. Well construction, borehole lithology, water withdrawals, and water levels presented in this report are described in a companion report by Elliott and Moreo (2011).

The term "well" as used in this report refers to a single, temporary, or permanent completion within a borehole that defines a discrete open interval. Each well completion interval is assigned a unique USGS site identification number and site (well) name, which is italicized in this report; borehole names are not italicized (table 1).

\section{Geochemical Data}

Geochemical data compiled in this report were determined by numerous institutions, laboratories, and individuals during the 50-plus year history of water-quality monitoring at the NNSS. Water-quality constituents reported in the database include $\mathrm{pH}$, specific conductance, major ion concentrations, trace element concentrations, environmental isotopes, radionuclides, and organic compounds. Historically, these data have been scattered in numerous published and unpublished reports that typically were produced by the different agencies or laboratories contracted to DOE. A major effort during the 2000s has been to compile these data into a single, comprehensive geochemical database that supports DOE's ongoing efforts to characterize potential radionuclide migration at the NNSS. This effort has been supported primarily by the DOE Underground Test Area (UGTA) Project, which is focused on understanding movement of groundwater into, through, and out of the NNSS (U.S. Department of Energy, 2009).

The geochemical database for the UGTA Project is a comprehensive compilation of data for wells, springs, and surface water in the NNSS region (Stoller-Navarro Joint Venture, 2008). Agencies participating in the UGTA Project that supplied water-quality data to the database include Desert Research Institute, Lawrence Livermore National Laboratory,
Los Alamos National Laboratory, U.S. Geological Survey (USGS), and various other local government and private contractors to DOE. The database is maintained by DOE's prime contractor and is updated annually to include newly acquired data. The database, referred to as GeochemXX.mdb (XX refers to the last two digits of the year of release), is distributed to UGTA Project participants and is available to the public upon request to DOE. Documentation of the database is provided in Stoller-Navarro Joint Venture (2008).

Data in this report are extracted from Geochem08, revision 3.0 released in September 2008 (Stoller-Navarro Joint Venture, 2008). Geochem08 is a relational database maintained in Microsoft ${ }^{\circledR}$ Access that contains compositional information for discrete samples collected from more than 1,800 uniquely identified sites. The database tracks the source of each piece of information to either the original publication, or the individual or institution that submitted the analysis. Although this database is a valuable resource, only limited efforts have been made to evaluate the quality of the data that are contained therein. Many of the older, unpublished analyses have not been individually scrutinized to evaluate whether they represent reasonable results, or whether they are anomalous relative to other analyses from the same site. Furthermore, the data for individual constituents may exist in multiple forms or units that have not been integrated. For instance, measurements of dissolved inorganic carbon contents may reside in any of more than 20 different database parameters that reflect the form in which the original data were submitted. Most constituents are reported as one of at least three designations including total, dissolved, or unspecified. Isotope data also can be given in different notations depending on the format obtained from the original data source.

A large number of $\mathrm{pH}$ and specific conductance measurements were collected from supply wells as part of routine monitoring efforts throughout the years (appendix A). Many of the measurements collected from about 1973 to 1986 are associated with a DOE Environmental Monitoring Program (DOE-EMP), and include widely scattered values compared to those reported before and after this period that were determined by different data sources. These data suggest that either large, erratic shifts in dissolved ion chemistry were present, or that problems exist with the data reported in the database. It is unlikely that all of the different aquifers penetrated by wells scattered widely across the NNSS behaved erratically at the same time. Therefore, $\mathrm{pH}$ and specific conductance measurements during this period are considered suspect, although the reasons for the poor reproducibility are not known. Plots demonstrating this variability are included in the individual well narratives that discriminate data sources by different laboratories. Other water-quality parameters for samples collected during this same period and reported by the same sources, also tend to show greater variability than other samples. Consequently, results from these sources (red text in appendix A) are still preserved in the Geochem.mdb database, but are considered unreliable and are not used in this report. 
Table 1. Locations, depths, and total groundwater withdrawals for supply wells on the Nevada National Security Site, Nye County, Nevada, 1951-2008.

[NNSS administrative area locations are shown in figure 1. L and-surface altitude: Values are in feet above National Geodetic Vertical Datum of 1929. Top and Bottom of open interval: Values are in feet below land surface. A bbreviations: MV, Mercury Valley; NNSS, Nevada National Security Site; USGS, U.S Geological Survey; ft, foot; m, meter; Mgal, million gallons]

\begin{tabular}{|c|c|c|c|c|c|c|c|c|}
\hline $\begin{array}{l}\text { Borehole } \\
\text { name }\end{array}$ & Well name & $\begin{array}{c}\text { USGS site } \\
\text { identification } \\
\text { No. }\end{array}$ & $\begin{array}{c}\text { NNSS } \\
\text { administrative } \\
\text { area }\end{array}$ & $\begin{array}{l}\text { Land-surface } \\
\text { altitude } \\
\text { (ft) }\end{array}$ & $\begin{array}{l}\text { Top of open } \\
\text { interval } \\
\text { (ft) }\end{array}$ & $\begin{array}{l}\text { Bottom of } \\
\text { open } \\
\text { interval } \\
\text { (ft) }\end{array}$ & $\begin{array}{c}\text { Period of } \\
\text { water } \\
\text { withdrawal }\end{array}$ & $\begin{array}{c}\text { Total } \\
\text { withdrawal } \\
\text { (Mgal) }\end{array}$ \\
\hline \multirow[t]{2}{*}{$\mathrm{J}-12 \mathrm{WW}^{1}$} & $J-12 W W(885 f t)$ & 364554116232400 & 25 & $3,128.4$ & 16 & 885 & Oct. 1957-July 1968 & 117 \\
\hline & $J-12 W W$ & 364554116232401 & 25 & $3,128.4$ & 16 & 1,139 & Aug. 1968-Dec. 2008 & 617 \\
\hline UE-5c WW & $U E-5 c W W$ & 365011115584702 & 05 & $3,216.3$ & 77 & 2,682 & Feb. 1967-Mar. 2006 & 153 \\
\hline \multirow[t]{2}{*}{ UE-15d WW ${ }^{1}$} & UE-15d WW (1735-6001 ft) & 371230116021500 & 15 & $4,586.2$ & 1,735 & 6,001 & Mar. 1962 & .17 \\
\hline & $U E-15 d W W$ (cased) & 371230116021501 & 15 & $4,586.2$ & 1,735 & 6,001 & Apr. 1962-Nov. 1981 & 351 \\
\hline UE-16d WW & $U E-16 d W W$ & 370412116095101 & 16 & $4,684.2$ & 81 & 1,944 & Mar. 1981-Dec. 2008 & 787 \\
\hline UE-19c WW & $U E-19 c W W$ & 371608116191002 & 19 & $7,033.1$ & 2,422 & 8,489 & July 1975-Sept. 1994 & 1,050 \\
\hline WW-4A & $W W-4 A$ & 365412116013901 & 06 & $3,605.7$ & 536 & 1,517 & Feb. 1990-Dec. 2008 & 790 \\
\hline WW-5A & $W W-5 A$ & 364635115572901 & 05 & 3,092.6 & 642 & 910 & Mar. 1951-Dec. 1970 & 262 \\
\hline WW-5B & $W W-5 B$ & 364805115580801 & 05 & $3,092.1$ & 700 & 900 & May 1951-Dec. 2008 & 1,720 \\
\hline WW-5C & $W W-5 C$ & 364708115574401 & 05 & $3,081.5$ & 20 & 1,200 & Apr. 1954-Dec. 2008 & 2,010 \\
\hline \multirow[t]{2}{*}{ WW- $8^{1}$} & $W W-8(2031-5490 \mathrm{ft})$ & 370956116172133 & 18 & $5,694.6$ & 2,031 & 5,490 & Jan. 1963 & .15 \\
\hline & $W W-8(30-2031 \mathrm{ft})$ & 370956116172101 & 18 & $5,694.6$ & 30 & 2,031 & Jan. 1963-Dec. 2008 & 1,800 \\
\hline WW-A & $W W-A(1870 f t)$ & 370142116021101 & 03 & $4,006.4$ & 1,555 & 1,870 & Sept. 1960-Oct. 1988 & 882 \\
\hline \multirow[t]{2}{*}{$W W-C^{1}$} & $W W-C(1373-1701 \mathrm{ft})$ & 365508116003501 & 06 & $3,924.2$ & 1,373 & 1,701 & Sept. 1961-Sept. 1966 & 210 \\
\hline & $W W-C$ (recompleted) & 365508116003502 & 06 & $3,924.2$ & 1,373 & 1,624 & May 1967-July 1995 & 1,070 \\
\hline WW-C-1 & $W W-C-1$ & 365500116003901 & 06 & 3,923.7 & 914 & 1,650 & June 1962-Dec. 2008 & 1,140 \\
\hline
\end{tabular}

\footnotetext{
${ }^{1}$ Borehole has multiple well-completion intervals discussed in this report. See Well name column for unique intervals.
} 
Major ion concentrations (appendix B), trace element concentrations, and environmental isotopes (appendix $\mathrm{C}$ ) for the remaining samples have been integrated into an internally consistent suite of analytes that represent as wide a time span as possible for each water-supply well. All dissolved inorganic carbon concentrations have been converted to total alkalinity as $\mathrm{HCO}_{3}{ }^{-}$(including $\mathrm{CO}_{3}{ }^{2-}$ if reported in the original analysis). Analyses also have been screened to identify spurious results. Charge balances for major ions that were greater than 10 percent were scrutinized closely to identify the cause. In many cases, one or more of the major ions were not reported for that entry. Despite these omissions, concentrations for the other major ions commonly remained consistent with those of earlier and later samples. In these cases, the incomplete analysis was retained, but identified by yellow shading of the row in appendix B.

Evaluations of compositional variations with time primarily rely on measurements of specific conductance and major ion concentrations. These parameters were selected because:

1. They were included in routine analyses from the earliest days of water-quality sampling at the NNSS;

2. They are easier and more reliable to analyze than other constituents; and

3. They are commonly distinct in different aquifers that may contribute water to a single well.

In contrast, determination of trace element concentrations and environmental isotopes in water samples has been less routine, especially during the early years of water-quality monitoring. The quality of trace element analysis also has evolved substantially during the past 50 years. Many of the early determinations were determined by wet chemistry or flame emission methods and are semiquantitative in nature (Claassen, 1973). Recent trace element analyses were done using inductively coupled plasma mass spectrometry, which yields greater precision and accuracy with far less analytical effort. Although some of these elements may be even more diagnostic of changing water sources or well conditions than the major ions, the data generally are not reliable enough, or of sufficient frequency, to allow meaningful comparisons. In particular, iron $(\mathrm{Fe})$ and manganese $(\mathrm{Mn})$ are two of a small number of trace constituents that were routinely reported for samples collected in the 1950s through the 1970s. Concentrations reported for these elements typically are imprecise (often reported to only one significant figure); are commonly reported at discrete levels rather than continuously variable values; are likely to vary by orders of magnitude and commonly are reported as much higher than values determined in more recent samples. Therefore, the large number of historical values reported for these two elements do not provide information useful for analyzing transient effects.

\section{Analytical Uncertainty}

Evaluation of long term temporal trends in water chemistry is complicated by the need to consider the effects of combined uncertainties on individual measurements. Although concentration data are reported in the Geochem.mdb database, analytical uncertainties associated with the determinations generally are not. Therefore, the random error or systematic analytical bias associated with each measurement generally is not known. Analytical errors are not always trivial with respect to the value reported, and relative errors for all concentrations increase as the absolute values decrease. Variations in sampling protocols between different participants over the years also may contribute to the total uncertainty associated with these data sets. Consequently, the total uncertainty includes some unknown combination of sampling artifacts, random and systematic intra-laboratory error, changes in analytical methodology, and inter-laboratory biases.

To better evaluate the veracity of potential trends, estimates of total uncertainty were included on all plots of concentration compared with time, as error bars associated with individual analyses. Additionally, estimates of measurement errors are plotted about median concentration values to help assess random scatter compared with systematic shifts. Error estimates were assigned values of 5 percent of the reported value for specific conductance measurements and major ions present at concentrations greater than few tens of milligrams per liter. As concentrations decrease, the ability to differentiate signal from noise becomes more difficult and analytical errors become larger. Decreases in accuracy and precision as concentrations approach minimum reporting limits typically are manifested as greater scatter of individual points about median values. Consequently, estimates of total uncertainty for major ions at low concentrations were increased to 10, and even 20 percent of the reported values. Estimates for total uncertainty assumed for individual major ions typically are consistent with values of two standard deviations (approximately 95-percent confidence levels) about the mean, for normally distributed data showing no time trends, and for variations in samples with replicate analyses. Errors for trace elements were assumed to be 20 percent of the measured value for older determinations, although this estimate of error may significantly underestimate true analytical error. A value of 10 percent was assumed for more recent trace element analyses. Analytical uncertainty at the 95-percent confidence level (that is, $2 \sigma$ ) for determinations of stable isotopes of hydrogen and oxygen was assumed to be $\pm 2 \%$ for $\delta^{2} \mathrm{H}$ and $\pm 0.2 \%$ for $\delta^{18} \mathrm{O}$. These assumed errors may underestimate the true analytical uncertainty of older determinations.

Historical water-quality data for a given supply well commonly have been determined by as many as five or more laboratories over the course of the withdrawal history 
of a well. Therefore, inter-laboratory analytical biases are a potential cause of variation, especially for older samples. Recent samples have been analyzed in duplicate, typically by multiple independent laboratories. This robust form of quality assurance is not available for older samples. Nevertheless, laboratories commonly use internal forms of quality control. Because samples (from a number of wells) have compositions with remarkably little change over a 40-year period of analysis, inter-laboratory biases are not an overwhelming problem. A few notable exceptions include many of the analytes associated with samples reported with unspecified dates in 1981 (shown in the appendixes as 01/01/1981 to facilitate plotting), as well as individual analyses having spurious concentrations clearly inconsistent with values determined from samples collected during similar periods.

The values used to estimate total uncertainty for individual analyses are specified on each plot. Despite this graphical depiction of total uncertainty estimated for individual determinations, statistical analyses of temporal trends did not include estimates of individual error, except for linear regression using York-fit methods. The purpose of showing these errors is to provide an additional means of judging whether to place confidence in a statistical outcome. For example, some trends identified as statistically significant at a probability level of 95 percent may show a total range of variation remaining within estimates of total uncertainty about a median value. In these cases, assumed uncertainties may be overestimated, or the reliability of the trend may be further questioned. Increasing the significance levels from 95 to 99 percent in these cases would likely result in a conclusion of "no trend." These considerations are addressed on a case-by-case basis for each constituent in the well descriptions.

\section{Trend Analysis}

The primary objective of this report is to evaluate whether systematic variations in chemical composition are present over the history of groundwater withdrawal at a given supply well, and if so, whether the trend can be attributed to changes in water withdrawals in the well. To identify systematic temporal variations in composition at a reasonably high level of confidence (95 percent confidence level is used throughout this report), a number of statistical methods have been developed for trend analysis (Gilbert, 1987; Helsel and Hirsch, 2002). All of these methods can quantify the presence of shifts in chemistry with time; however, they differ in terms of appropriateness and robustness, based on whether the sample populations follow reasonably close approximations to normal distributions. For data known to be normally distributed, parametric statistical approaches, such as least-squares linear regression of constituent concentration compared with time, are appropriate and robust methods of trend analysis. However, groundwater-quality data commonly do not follow normal distributions, but are skewed toward lower concentrations with tails extending to high values. Trends for these data sets are more appropriately evaluated using nonparametric methods that do not require knowledge of the true statistical distribution of the data set. Parametric and nonparametric tests lose statistical power (the probability of identifying that a trend does exist) when applied to small sample sets, especially if the number of analyses is less than 10. Results from trend analyses calculated in these cases should be considered less reliable than those with larger sample sizes.

Methods of trend analysis in this report use graphical as well as parametric and nonparametric statistical approaches. Data for specific conductance and major ions are plotted against time. Visual observation is adequate to identify large shifts in composition present in a number of wells and allows for identification of obvious outliers. After removal of outliers, the distribution of each constituent was evaluated for normality using several tests including Studentized Range, Anderson-Darling, Ryan-Joiner, and KolmogorovSmirnov tests. Results indicating that the data either passed or failed these separate tests at the 95 percent confidence limit are given in appendix D. Trend analyses using two nonparametric methods (Mann-Kendall and Sen's Estimator of Slope) and two parametric methods (least-squares linear regression and 2-error regression or York-fit) also are given in appendix D. Multiple analyses reported for samples with the same collection date were averaged prior to applying any trend analysis.

The Mann-Kendall test (MK) provides a means of quantifying whether a dataset displays an overall increase or decrease with time. The test does not require that the data conform to any particular distribution, and it is not sensitive to missing data or measurements that are spaced irregularly in time. The test produces a Mann-Kendall statistic (S) that tallies the number of instances a value in a time-ranked sequence is higher or lower than earlier or later values (Gilbert, 1987; Gibbons, 1994). A high positive value of S indicates an overall increasing trend whereas a low negative value indicates an overall decreasing trend. To calculate the probability associated with $\mathrm{S}$, a second normalized test statistic, Z, is calculated based on the variance of $\mathrm{S}$. The probability associated with $\mathrm{Z}$ is then computed and given as a percentage in appendix D. Groundwater constituents that have a positive $\mathrm{S}$ and $\mathrm{Z}$ test statistic, and a probability less than 5 percent, are considered to reflect an increasing trend with time at a confidence level of greater than 95 percent. If $\mathrm{S}$ and $\mathrm{Z}$ have negative values and the probability is less than 5 percent, the trend is considered to be decreasing with time at a confidence level of greater than 95 percent. Constituents with $S=0$, or with probabilities greater than 5 percent are considered to have no trend with time. Mann-Kendall analyses were performed using the commercially available software package AquaChem ${ }^{\circledR} 2010.1$ (Schlumberger Water Services, 2010). 
The second nonparametric method for trend analysis uses Sen's nonparametric estimator of slope (Sen's slope test). This test was developed to estimate the true slope of measured values with time and is relatively insensitive to the presence of outliers and missing data (Sen, 1968). The approach computes concentration/time slopes for all pairs of data and uses the median value as an estimate of the true slope (values given in appendix D). The variance for these multiple slopes is calculated and used to establish upper and lower confidence limits (Gilbert, 1987), considering the specified probability level ( 95 percent). If the confidence interval includes zero (spans a range of positive and negative values), the median slope is considered indistinguishable from zero, and no trend is reported. If both limits are positive or negative numbers, that is, the limits do not straddle zero, an increasing or decreasing trend, respectively, is reported. Sen's slope tests were performed using the software package AquaChem ${ }^{\circledR} 2010.1$.

In addition to nonparametric methods, least-squares linear regressions were calculated for each water-quality constituent to assess the degree of covariation between concentration and time. Regression analysis was calculated using the commercially available software (Minitab ${ }^{\circledR} 15.1$; Minitab Inc., 2007) which tests the null hypothesis that the slope of the resulting linear relation is indistinguishable from zero by calculating a p-value between 0 and 1 (values given in appendix D). If this value is less than 0.05 (corresponding to the 95 percent confidence limit), the null hypothesis can be rejected in favor of the alternative hypothesis that the slope is distinct and a systematic change in composition with time is likely. Additionally, the $\mathrm{R}^{2}$ value (coefficient of determination) also is reported and gives the fraction of the variance that is explained by the regression, ranging between a value of 1 for a perfect correlation and 0 if there is no correlation. However, in order for conclusions based on linear regressions to be valid, several assumptions about the distribution must be met (Helsel and Hirsch, 2002, p. 225). The most important of these is that the residuals (difference between measured and predicted values) conform to a normal distribution. If not, hypothesis tests can yield inaccurate results (Helsel and Hirsch, 2002, p. 235). Simple linear regression results reported in appendix D include a column indicating whether residuals fail or pass an Anderson-Darling normality test. As with the calculation of statistical means, linear regressions are sensitive to the presence of outliers in a data set, especially if they are present in either the early or late parts of the period of record. Data points not included in regression analyses are shown as open symbols in concentration compared to time plots shown in the Well Descriptions section of the report.

Another limitation of simple least-squares linear regression is that values given for the explanatory variable ( $\mathrm{X}$ value, or time) and the response variable ( $\mathrm{Y}$ value, or concentration) are assumed to be accurately determined. Although this assumption is reasonable for most (but not all) sampling dates, the reliability of concentrations varies considerably (see section Analytical Uncertainty). More sophisticated methods of XY regression that consider errors in both variables (York-fit regressions; York, 1969) provide a more realistic means of slope fitting, as well as propagating errors associated with slopes (maximum likelihood estimation algorithm of Titterington and Halliday, 1979). Because analytical uncertainties for individual major ion constituents are rarely reported, blanket uncertainties for each chemical constituent (given for each constituent on plots of concentration compared with time in the Well Descriptions section) were used to produce 2-error regression models (calculated using the software package IsoPlot/ Ex 3.00; Ludwig, 2003). Blanket errors also were assigned to all dates (0.01 percent of given value or about 4 days). Calculated slopes in milligrams per liter per year and associated 95-percent-confidence level uncertainties are given in appendix D.

Trend analysis results presented in appendix D and summarized in tables for most wells in the Well Descriptions section are used to support conclusions regarding the statistical significance of increasing or decreasing concentrations with time. The exception is UE-19c WW, which does not have sufficient data to warrant trend analysis (only sampled four times between 1990 and 1992). Although all results of parametric tests are preserved in appendix D, those that do not pass normality criteria (passing three out of four normally distributed population tests as well as passing normality tests on regression residuals) are not considered valid and are listed as a dash (-) in the summary tables for each well in the Well Descriptions section. Conclusions in these cases are solely based on the results of nonparametric tests. Parametric tests provide more reliable conclusions when sample populations and regression residuals meet normality criteria. Constituents that show statistically significant trends with time are highlighted with yellow shading in appendix D and bold text in summary tables, and are shown as thick sloping lines on time-series plots in the Well Descriptions section. All statistical tests indicated as significant have passed the statistical criteria at the 95 percent level of confidence unless otherwise indicated.

Results of multiple trend tests are remarkably consistent-of the 10 constituents evaluated for each of the 19 sets of data analyzed for trend, results of Mann-Kendall and Sen's slope tests agree in 181 of 189 cases. Parametric test results agree with nonparametric test results in 111 of 189 cases with 68 cases failing the normality test. Only 6 linear regression test-results out of all 189 possibilities clearly conflict with nonparametric test results. Results in the few cases that give contradictory results are considered inconclusive. Therefore, the small amount of uncertainty introduced by using the multi-test approach in this report is more than countered by the confidence gained through the overwhelming agreement of multiple, independent statistical tests. 
Statistical methods applied here can detect only monotonic shifts in composition over the entire period analyzed. Shorter-term or cyclic variations in composition may be present over the history of water withdrawals for a given well. However, available chemical measurements are commonly not sufficient in terms of frequency or quality to evaluate any shorter-term trends. In a few cases (for instance, Army $1 \mathrm{WW}$ ) monotonic shifts shorter than the entire period of record are obvious on time-series plots. These periods were evaluated for trend analyses separately from the entire set of time-series data. The possibility of correlating shorter-term variations in composition (systematic or random scatter) with variations in pumping is facilitated by the inclusion of histograms showing annual water withdrawals on all timeseries plots of conductance and major ion concentrations.

In addition to continuous monotonic shifts, time-series plots for several wells show evidence of apparent step trends (for example, WW-5B, WW-5C, WW-A). Commonly, early and late groupings of samples can be made based on changes in withdrawal history within a given well or cluster of nearby wells. To test whether the differences between groupings is significant, several statistical methods have been applied. If both groups of data satisfy requirements for the assumption of normal distributions with equal variances, standard twosample t-tests are most appropriate for evaluating whether the two means are statistically distinguishable at the 95 percent (or higher) level of confidence (Helsel and Hirsch, 2002, p. 124). Because these assumptions may not be met by one or both of the data groups, nonparametric methods have been developed that do not require sample populations to have known distributions. In this report, a rank-sum test (Mann-Whitney) was used to evaluate whether differences in median values between the two groups are significant based only on the order (ranking) of the observations from the two groups of samples (Wild and Seber, 1999). In practice, both tests were applied when comparing central locations of two separate groups of data. Typically, parametric and nonparametric test results indicate whether differences between central locations (means or medians) were significant.

Qualitative conclusions regarding correlations between chemical variations and withdrawal history are made by visual comparison in this report. Patterns of annual water withdrawals are superimposed on time-series chemistry plots to facilitate this comparison. Withdrawal data used in these plots were compiled by Elliott and Moreo (2011), and are summarized in appendix E as histograms showing numerical values for annual withdrawals for each well.

\section{Well Descriptions}

Descriptions for each of the supply wells listed in table 1 are developed in the following sections. The descriptions provide information on the physical characteristics of each well along with relevant hydrostratigraphic and water withdrawal information. A companion report by Elliott and Moreo (2011) contains more detailed information on well construction, water withdrawals, and water levels. Overall chemical relations are presented on trilinear diagrams showing major ions (Piper, 1944). Variations in the groundwater compositions for multiple samples from an individual well typically are limited; however, differences in compositions between wells are large and generally reflect the composition of the aquifer producing the water (fig. 2). Groundwater produced from supply wells varies from compositions highly enriched in sodium (Na) plus potassium (K) typical of volcanic aquifers (U-20 WW) or alluvium dominated by zeolitized volcanic rock (WW-5A, WW-5C), to compositions dominated by calcium (Ca) plus magnesium (Mg) typical of carbonate aquifers (UE-16d WW, Army $1 \mathrm{WW}$ ).

Water-quality data are included in appendix $\mathrm{A}$ (pH and specific conductance), appendix B (major ion concentrations), and appendix C (trace element concentrations and environmental isotopes). These appendixes are included as interactive spreadsheets that allow sorting data by well name. Evaluation of temporal trends for each well is primarily based on specific conductance and major ion concentration data plotted against time. Statistical outcomes for the various statistical tests are tabulated in appendix D and summarized in the following descriptions for individual supply wells. Available trace element concentrations and environmental isotope data also are discussed, where relevant. Additional supporting information is included in appendix E and consists of schematic logs showing hydrostratigraphic units, lithologic units, and well construction features, as well as plots of annual groundwater withdrawal and trilinear diagrams for individual wells. Basic statistical information (median, mean, and variances) for major ion data are given in appendix $F$.

The presentation of water-quality data in this report is largely confined to compositional variations with time with little or no discussion devoted to the origins of the groundwater present at a given well. These issues have been addressed in recent studies of the origins, flow paths, and travel times of groundwater in Frenchman Flat (Hershey and others, 2005), Yucca Flat (Farnham and others, 2005), Pahute Mesa (Rose and others, 2006), and Rainier Mesa (Hershey and others, 2008). 
A.

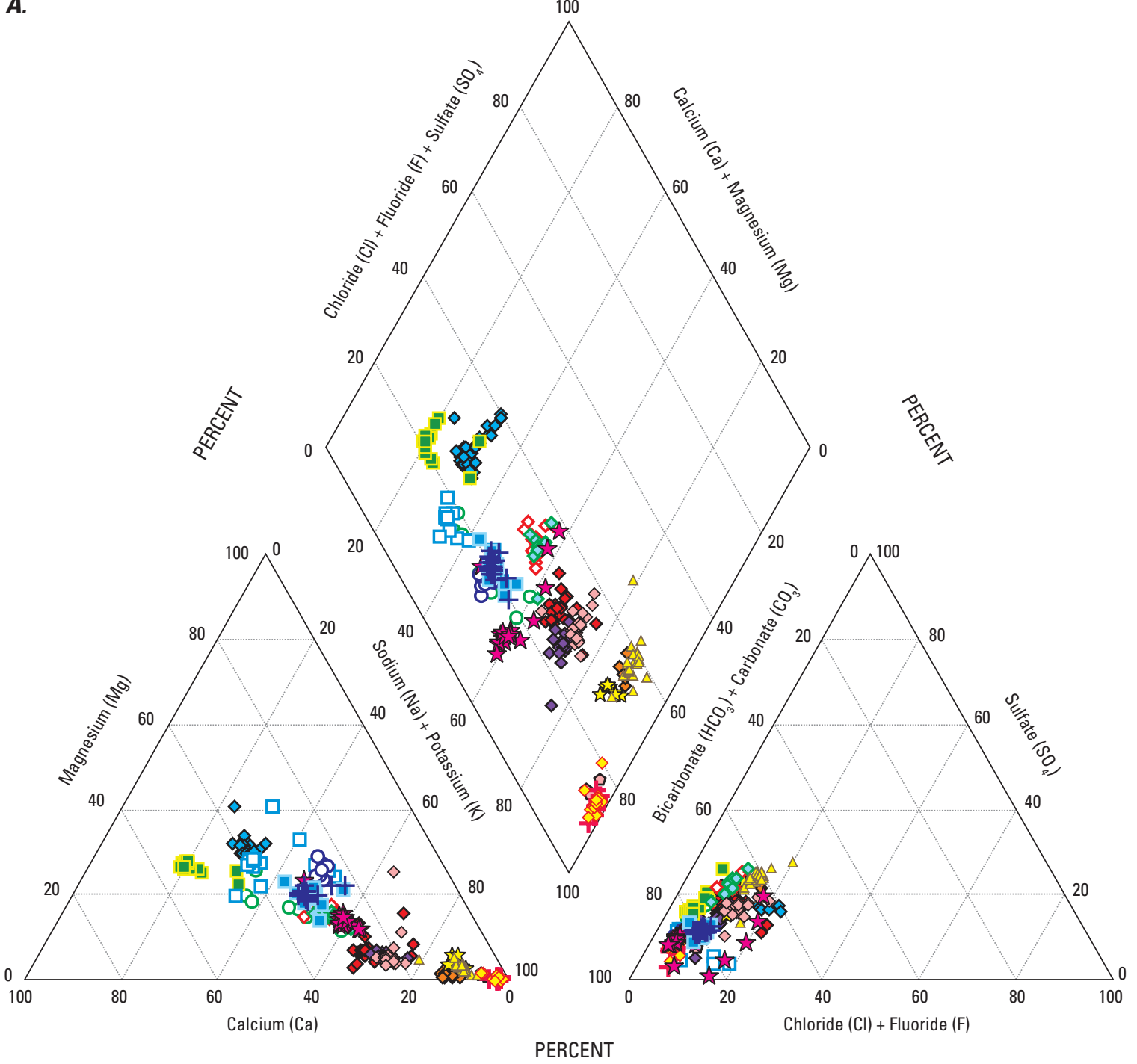

EXPLANATION

\begin{tabular}{|c|c|c|c|}
\hline ARMY $1 \mathrm{WW}$ & O UE-15d WW & $\diamond W W-4$ & $\diamond W W-8(30-2,031 \mathrm{ft})$ \\
\hline$J-12 W W$ & - UE-16 d WW & $\diamond W W-4 A$ & $\hbar \mathrm{WW}-\mathrm{A}(1,870 \mathrm{ft})$ \\
\hline$J-13 W W$ & D UE-19c WW & $+W W-5 A$ & I WW-C (recompleted) \\
\hline U-20 WW (cased) & $\square$ WW-2 $(3,422 \mathrm{ft})$ & $\Delta W W-5 B$ & $+W W-c 1$ \\
\hline UE-5c WW & O WW-3 (1,800ft) & $\diamond W W-5 C$ & \\
\hline
\end{tabular}

Figure 2. Major ion concentrations grouped by $(A)$ wells and $(B)$ hydrostratigraphic units in samples from water-supply wells on the Nevada National Security Site, Nye County, Nevada. 
B.

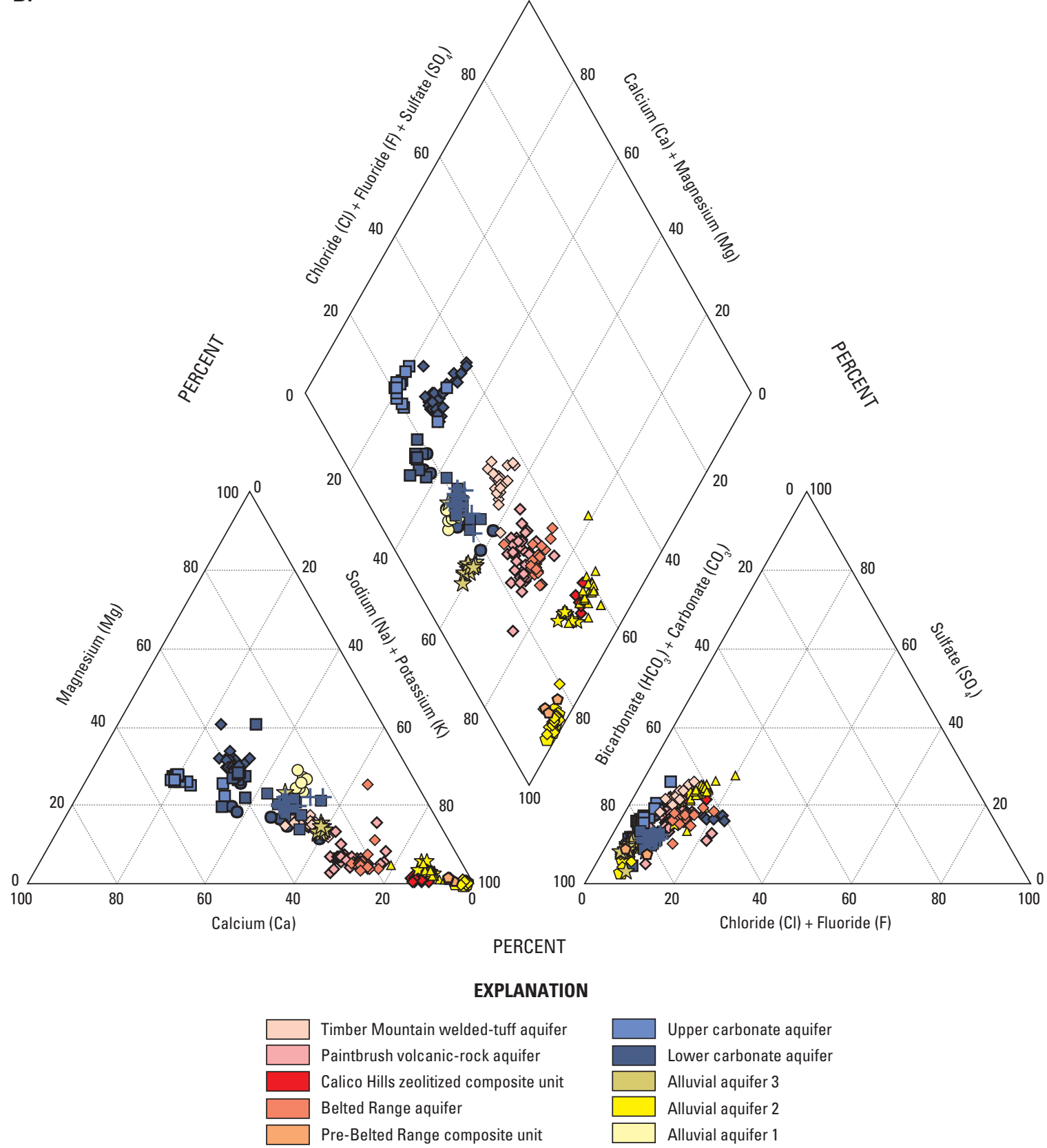

Figure 2.-Continued 


\section{Army 1 WW}

Borehole Description and Water Withdrawals: Army $1 \mathrm{WW}$ is in Area 22 of the NNSS (fig. 1; table 1), about $5 \mathrm{mi}$ southwest of Mercury, Nevada. The borehole originally was drilled to a depth of $620 \mathrm{ft}$ below land surface in July 1958, and deepened in July 1962 to a total depth of 1,946 ft. The single completion in the borehole, well Army 1 WW (MV-1), has casing cemented to 1,360 ft and a perforated zone from 800 to $1,050 \mathrm{ft}$. The annular space between the casing and borehole is open from about 610 to $1,120 \mathrm{ft}$. The well is open (uncased) below a depth of about $1,360 \mathrm{ft}$ (appendix E, fig. E-1), and the mean water level in the well is at a depth of $786 \mathrm{ft}$ below land surface.

Borehole lithology consists of alluvium and nonwelded tuff from 0 to $610 \mathrm{ft}$, and carbonate rocks and shale from 610 to 1,946 ft (appendix E, fig. E-1) (Wood, 2007). The two open zones in the well produce water from the lower carbonate aquifer (LCA) hydrostratigraphic unit (HSU). The upper zone between the water table and 1,120 ft below land surface penetrates dolomite constituting the Smoky Member and limestone constituting the Halfpint Member of the Late Cambrian Nopah Formation. This zone includes a $25 \mathrm{ft}$ thick interval of vuggy fault breccia at about $850 \mathrm{ft}$ below land surface. The lower zone extends from 1,360 to 1,946 ft below land surface and penetrates carbonate rocks of the Middle to Late Cambrian Bonanza King Formation. Carbonate rocks constituting the two open zones are separated by approximately $170 \mathrm{ft}$ of argillite or shale that may form at least a partial barrier to vertical flow within the LCA at this site.

Army 1 WW supplied water primarily to support NNSS operational activities in and around Mercury from July 1962 to September 2005. About 2,440 Mgal of water have been pumped from the well since 1962 (table 1). Annual withdrawals varied over the years (appendix E, fig. E-2), with the greatest amounts of pumping (106-139 million gallons per year [Mgal/yr]) between 1989 and 1993 (Elliott and Moreo, 2011). Annual withdrawals decreased dramatically throughout the mid- to late-1990s to less than $1 \mathrm{Mgal}$ in 2000. Subsequent annual pumping increased progressively from about $38 \mathrm{Mgal}$ in 2001 to $80 \mathrm{Mgal}$ in 2005. Use of Army $1 \mathrm{WW}$ for water supply ceased in September 2005 to comply with new, lower limits for arsenic concentrations allowable in drinking water (Wills, 2006, p. 4-24 and 4-27).

Water Quality: Water from Army $1 \mathrm{WW}$ has compositions dominated by $\mathrm{Ca}, \mathrm{Mg}$, and $\mathrm{HCO}_{3}$ (appendix B) and generally reflect rock composition of the LCA. Most data plot in a small cluster on a trilinear diagram (appendix E, fig. E-3). However, a small number of analyses have higher $\mathrm{Cl}+\mathrm{F}$ concentrations and form a linear array extending away from the main cluster. Total dissolved solids content (as indicated by specific conductance) remained essentially constant from July 1962 to April 2001 (fig. 3). Most specific conductance measurements made during this period were within analytical uncertainty of the median value of $537 \mu \mathrm{S} / \mathrm{cm}$, including samples collected during periods of above average withdrawal from about 1989 to 1993 and below average withdrawal from 1994 to 2000 (average annual withdrawal rate from 1962 to 2008 was $51.8 \mathrm{Mgal})$. Both nonparametric trend tests (MK and Sen's) indicated that there was no significant change in specific conductance from July 1962 to April 2001 (table 2; appendix D-1). However, specific conductance increased monotonically from about $541 \mu \mathrm{S} / \mathrm{cm}$ in April 2001 to $663 \mu \mathrm{S} / \mathrm{cm}$ in July 2005 (fig. 3B). All statistical tests indicate that the increasing trend in conductance during this period is significant at high degrees of certainty (table 2; appendix D-1). This compositional trend occurred during the same period that annual pumping increased from less than $1 \mathrm{Mgal}$ in 2000 to more than $80 \mathrm{Mgal}$ in 2005. However, annual rates of pumping between 2001 and 2005 ranged from 37.55 to $80.37 \mathrm{Mgal}$ (mean value $=59.3 \mathrm{Mgal}$ ), which are similar to annual pump rates from 1964 to 1988 (25.63 to 96.10 Mgal with a mean value = 55.9 Mgal; Elliott and Moreo, 2011, appendix A). Therefore, the observed trend of increasing specific conductance in Army $1 \mathrm{WW}$ groundwater cannot be attributed to changing pump rates alone. Following cessation of pumping for water-supply purposes in late September 2005, specific conductance measured on October 19, 2005, returned to a value of $543 \mu \mathrm{S} / \mathrm{cm}$, which is nearly identical to the long-term average.

Temporal changes in specific conductance are reflected in major ion concentrations (fig. 4). Groundwater samples from July 1962 to July 2000 show no evidence of systematic shifts in concentration except for $\mathrm{Na}$, which showed a significant increasing trend from about 37 to $40 \mathrm{mg} / \mathrm{L}$. However, starting in the early 2000s, several major ions show statistically significant trends in concentration (table 2; appendix D-1). The largest shift is in $\mathrm{Cl}$ concentrations, which increased from $16.6 \mathrm{mg} / \mathrm{L}$ in July 2000 to $52.7 \mathrm{mg} / \mathrm{L}$ in July 2005. Concentrations of $\mathrm{Na}, \mathrm{Ca}, \mathrm{Mg}$, and $\mathrm{SiO}_{2}$ also show significant increasing trends during this period. Both two-sample t-tests and Mann-Whitney rank tests indicate that these differences are significant at the 95-percent confidence level. Statistically significant trends are not apparent for $\mathrm{HCO}_{3}$ and $\mathrm{F}$; however, concentrations for both of these constituents were lower during the more recent period of pumping relative to values obtained before 2000 . Concentrations of $\mathrm{SO}_{4}$ have remained constant during the history of groundwater withdrawal at Army $1 \mathrm{WW}$.

Only a small number of trace elements were analyzed in Army 1 WW samples between 1962 and 1976, including $\mathrm{B}, \mathrm{Li}, \mathrm{Se}, \mathrm{Sr}$, and U (appendix C). Given the large analytical uncertainties and small number of individual analyses obtained from samples collected prior to 1979, assessment of any long term temporal trends is considered unreliable. A larger suite of more reliably determined elements and environmental isotopes has been obtained from samples collected starting in 1979; however, the only data available for water sampled between 2001 and 2005 is a single sample collected in May 2003. 


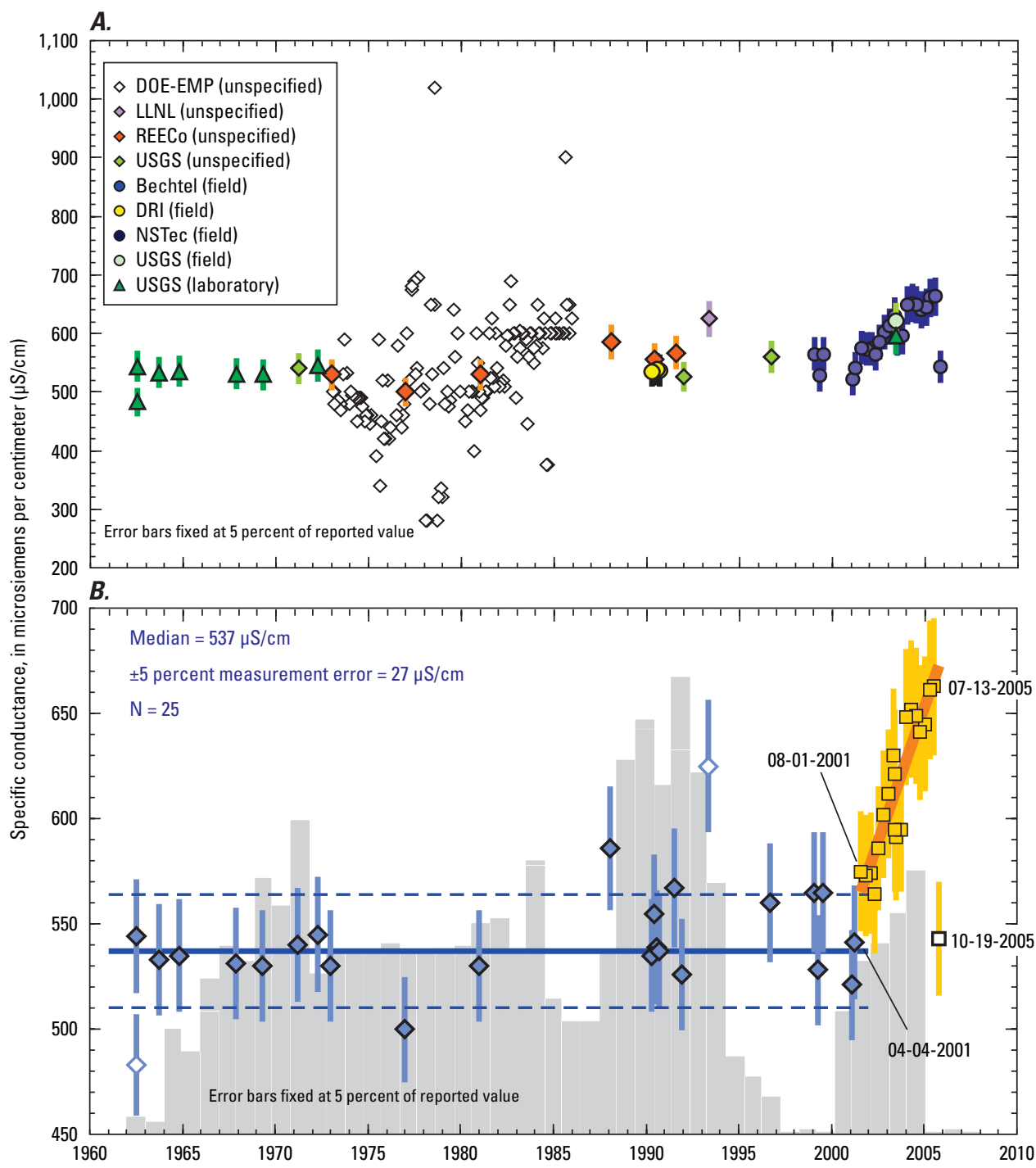

Figure 3. Temporal variations in specific conductance for water samples collected from Army 1 WW, Nevada National Security Site, Nye County, Nevada. (A) All available specific conductance data from appendix $A$ identified by source including Bechtel, Bechtel Nevada; DOE-EMP, Department of Energy Environmental Monitoring Program; DRI, Desert Research Institute; LLNL, Lawrence Livermore National Laboratory; NSTec, National Security Technologies, LLC; REECo, Reynolds Electrical \& Engineering Co., Inc.; and USGS, U.S. Geological Survey. Reported measurements were either made in the field, the laboratory, or were unspecified in the database. $(B)$ Specific conductance data used to calculate the median value and trend analysis are shown as filled symbols. Open symbols are outliers and were not included in numerical evaluations. Thick, horizontal blue line represents the median value shown along with estimates for 5 percent measurement error (dashed blue lines) for groundwater sampled between July 1962 and April 2001. Data for samples collected between August 2001 and July 2005 (orange squares) yield a statistically significant trend (orange sloping line; see results in appendix D). Shaded histogram represents the record of annual groundwater withdrawals from Army 1 WW (see appendix $E$, fig. E-2 for withdrawal values). 
Table 2. Results of trend analyses for major constituents in water pumped from Army 1 WW, Nevada National Security Site, Nye County, Nevada, between July 10, 1962, and July 13, 2005.

[A bbreviations: MK, Mann-Kendall test; SES, Sen's estimator of slope test; LR, linear regression; -, not applicable]

\begin{tabular}{|c|c|c|c|c|c|c|}
\hline Constituent & $\begin{array}{c}\text { Total } \\
\text { samples }\end{array}$ & $\begin{array}{l}\text { Normality } \\
\text { tests }\end{array}$ & $\begin{array}{c}\text { MK } \\
\text { result }\end{array}$ & $\begin{array}{c}\text { SES } \\
\text { result }\end{array}$ & $\begin{array}{c}\text { Residual } \\
\text { normality } \\
\text { test }\end{array}$ & $\begin{array}{l}\text { LR } \\
\text { result }\end{array}$ \\
\hline \multicolumn{7}{|c|}{ July 10, 1962 to April 4, 2001} \\
\hline Conductivity & 23 & failed & no trend & no trend & - & - \\
\hline Calcium (Ca) & 23 & failed & no trend & no trend & - & - \\
\hline Magnesium (Mg) & 23 & failed & no trend & no trend & - & - \\
\hline Sodium (Na) & 22 & passed & increasing & increasing & failed & - \\
\hline Potassium (K) & 23 & passed & no trend & no trend & passed & no trend \\
\hline Chloride (Cl) & 25 & failed & no trend & no trend & - & - \\
\hline Bicarbonate $\left(\mathrm{HCO}_{3}\right)$ & 24 & failed & no trend & no trend & - & - \\
\hline Sulfate $\left(\mathrm{SO}_{4}\right)$ & 23 & inconclusive & no trend & no trend & inconclusive & no trend \\
\hline Silicon dioxide $\left(\mathrm{SiO}_{2}\right)$ & 18 & passed & no trend & no trend & passed & no trend \\
\hline Fluoride (F) & 20 & failed & no trend & no trend & - & - \\
\hline \multicolumn{7}{|c|}{ August 1, 2001 to July 13, 2005} \\
\hline Conductivity & 17 & passed & increasing & increasing & passed & increasing \\
\hline Calcium (Ca) & 9 & passed & increasing & increasing & failed & - \\
\hline Magnesium (Mg) & 9 & passed & increasing & increasing & passed & increasing \\
\hline Sodium (Na) & 9 & passed & increasing & increasing & passed & increasing \\
\hline Potassium (K) & 9 & passed & no trend & no trend & passed & no trend \\
\hline Chloride (Cl) & 9 & passed & increasing & increasing & passed & increasing \\
\hline Bicarbonate $\left(\mathrm{HCO}_{3}\right)$ & 9 & passed & no trend & no trend & passed & no trend \\
\hline Sulfate $\left(\mathrm{SO}_{4}\right)$ & 9 & passed & no trend & no trend & passed & no trend \\
\hline Silicon dioxide $\left(\mathrm{SiO}_{2}\right)$ & 9 & passed & no trend & no trend & passed & increasing \\
\hline Fluoride $(\mathrm{F})$ & 9 & passed & no trend & no trend & passed & no trend \\
\hline
\end{tabular}



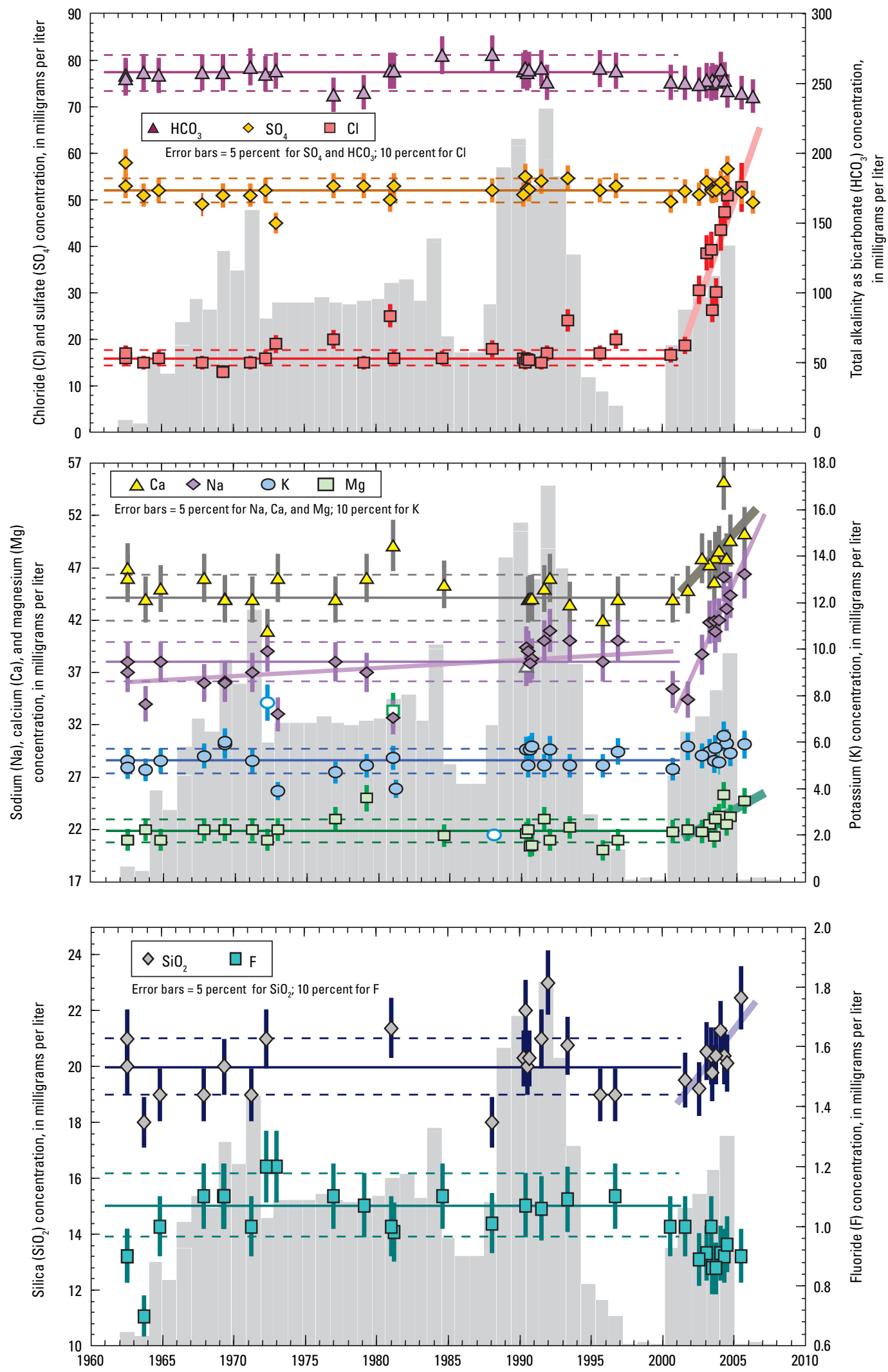

Figure 4. Temporal variations in major-ion concentrations for water samples collected from Army 1 WW, Nevada National Security Site, Nye County, Nevada. Filled symbols represent data from appendix B used to calculate trend analyses and quantitative statistics (see results in appendix D and appendix F, respectively). Open symbols represent outliers and were not included in numerical evaluations. Solid horizontal lines represent median concentration values for water sampled from July 1962 to July 2000 shown along with estimated measurement error (dashed horizontal lines) using the same values given for error bars on individual analyses. Thick sloping lines represent statistically significant trends. Shaded histogram represents annual groundwater withdrawals from Army $1 \mathrm{WW}$ (see appendix E, fig. E-2 for withdrawal values). 
The concentration of Sr in the 2003 sample $(831 \mu \mathrm{g} / \mathrm{L})$ is substantially higher than values from 1993 and 1996 samples (744 and $770 \mu \mathrm{g} / \mathrm{L}$, respectively, appendix C), and likely correlates with the small increase in Ca (fig. 4). Similar concentration increases may be present for $\mathrm{B}, \mathrm{Ba}, \mathrm{Li}$, and $\mathrm{U}$ in the 2003 sample compared to mean concentrations for these elements analyzed in samples from the 1990s; however, these potential differences are not compelling.

Five paired analyses of $\delta^{2} \mathrm{H}$ and $\delta^{18} \mathrm{O}$ for water collected from Army 1 WW between 1982 and 2003 are intermediate within the range for NNSS waters $\left(-99\right.$ to $-102 \%$ for $\delta^{2} \mathrm{H}$ and 13.1 to $-13.5 \%$ for $\delta^{18} \mathrm{O}$; fig. 5 and appendix C). The only data reported for samples collected from 2001 to 2005 have a composition that is analytically indistinguishable from values reported for samples collected in the early to mid-1990s. The similarity of these data indicate that the progressive changes for specific conductance and major ion concentrations during 2001 to 2005 was not accompanied by a shift in contributions from aquifers with substantially different source water, either in time or space.

Compositional shifts in specific conductance and major ion concentrations in water pumped between 2001 and 2005 from Army $1 \mathrm{WW}$ appear to coincide with an increase in water withdrawal during this same period. This chemical response is unique in the history of this well—a similar increase in pumping from 1988 to 1994 (fig. 4) did not result in a comparable effect on groundwater composition.
Also, pumping rates in the early 2000s were similar to those experienced from 1964 to 1988 during which compositions remained uniform and distinct from the trend of the 2000s. Although two producing zones were penetrated in this borehole, they were never isolated and sampled separately. Therefore, it is not known if the changes in specific conductance and major-ion chemistry were caused by greater contributions from one zone or the other at different times, or if groundwater with a distinct composition containing higher $\mathrm{Cl}, \mathrm{Na}, \mathrm{Ca}, \mathrm{Mg}, \mathrm{SiO}_{2}$, and $\mathrm{K}$ entered the borehole during the latest period of increased pumping. The fundamental change in chemical behavior also could be related to the period of reduced pumping between 1998 and 2000, which had never occurred before. The results of limited pumping on what was previously a more-or-less steady-state flow condition within the aquifer are not known. Limited dissolved oxygen data and concentrations of redox-dependent trace elements (As and U) collected both before and after 2000 remained more-orless uniform. This implies that changes in redox conditions caused by degradation of well components was not a major contributor to the observed compositional shifts. Water-quality samples from the most recent period of decreased production (post-September 2005) were not available at the time the data in this report were compiled, although they would be important in assessing whether chemical compositions have returned to pre-2000 values.

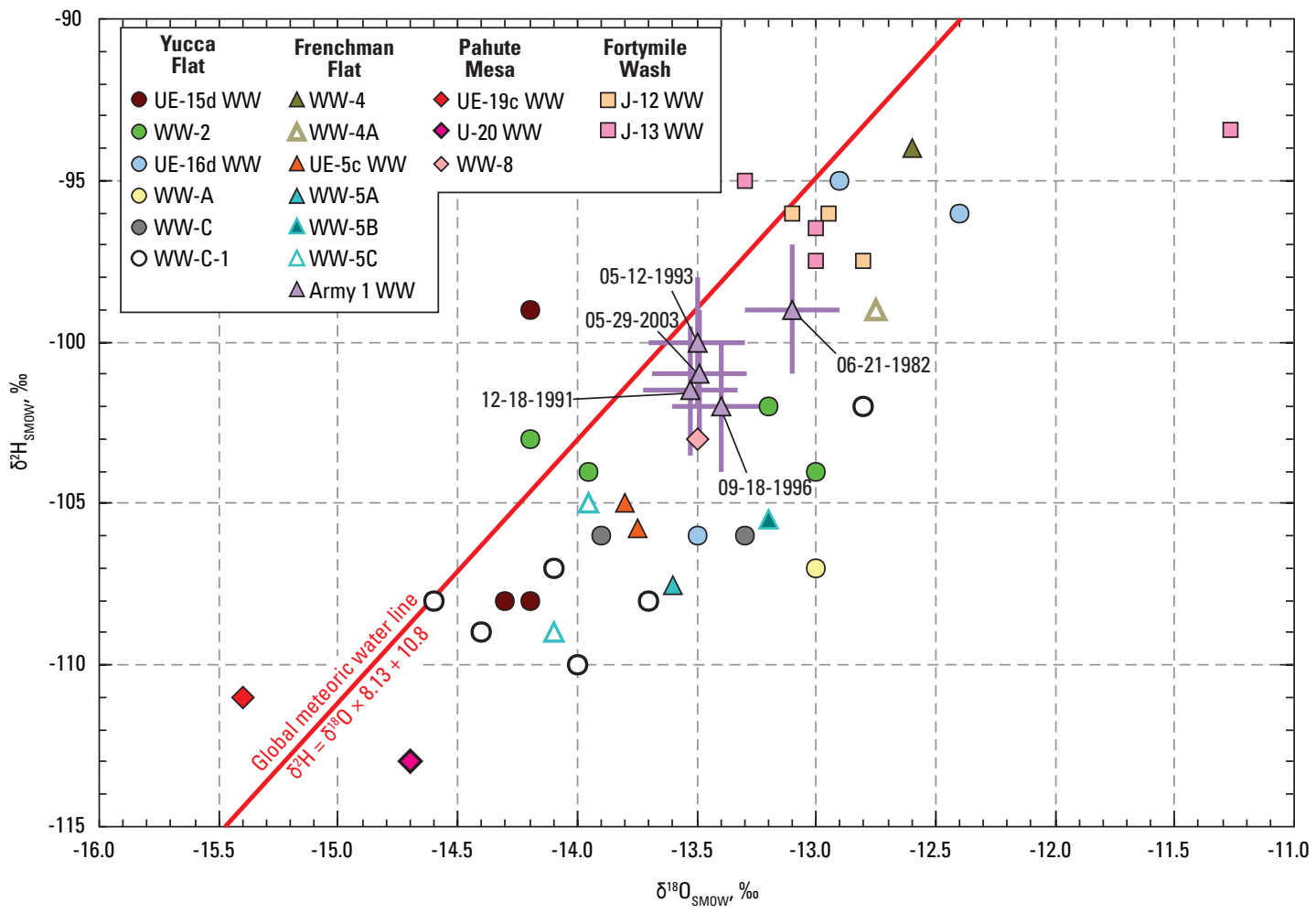

Figure 5. Isotopic compositions of hydrogen and oxygen for water sampled from Army $1 \mathrm{WW}$ and data from other water-supply wells at the Nevada National Security Site, Nye County, Nevada. 


\section{J-12 WW}

Borehole Description and Water Withdrawals: J-12 WW is on the southwest edge of Jackass Flats in Area 25 of the NNSS (fig. 1; table 1). The borehole originally was drilled to a depth of $885 \mathrm{ft}$ in October 1957. This first well completion, $J-12 W W(885 \mathrm{ft}$ ), was cased to the total depth of the borehole with a perforated zone from 791 to $865 \mathrm{ft}$. The annular space between the casing and borehole was open from 16 to $885 \mathrm{ft}$ (Elliott and Moreo, 2011). The borehole was deepened in August 1968 to a depth of 1,139 ft and the subsequent well completion, J-12 WW (appendix E, fig. E-4), was left uncased and open from 885 to $1,139 \mathrm{ft}$ within the welded tuff unit (Thordarson, 1983, p. 50). The mean water level in the most recent completion, well $J-12 \mathrm{WW}$, is at a depth of $740 \mathrm{ft}$ below land surface.

Borehole lithology consists of alluvium from 0 to $515 \mathrm{ft}$, and welded and nonwelded tuffs from 515 to $1,139 \mathrm{ft}$ (appendix E, fig. E-4; Moore, 1962, p. 28-29; Claassen, 1973, p. 24). The water level is within densely welded units of the Topopah Spring Tuff, and water from this well is produced from secondary fracture permeability in the Paintbrush volcanic-rock aquifer HSU (Faunt and others, 2004; Fenelon and others, 2010, appendix 3).

J-12 WW originally supplied water for U.S. Atomic Energy Commission activities in Jackass Flats (Moore, 1962, p. 27). Since the 1980s, J-12 WW was used, along with J-13 WW, to supply water for site characterization and construction activities associated with the Yucca Mountain Project nuclear waste isolation program. More than $733 \mathrm{Mgal}$ of water have been pumped from J-12 WW since October 1957 (Elliott and Moreo, 2011). Of this total, about 117 Mgal of water were pumped from the original completion, well J-12 WW (885 ft), from October 1957 to July 1968 (appendix E, fig. E-5). About $617 \mathrm{Mgal}$ of water were pumped from the subsequent completion (well $J-12$ WW) (Elliott and Moreo, 2011). Only minor pumping occurred from well $J-12 \mathrm{WW}$ between 1968 and 1980; however, annual pumping increased between

1980 and 1996 to support Yucca Mountain site characterization. Withdrawals of 13-48 Mgal/yr were pumped during this 16-year period. After completion of the underground exploratory facilities at Yucca Mountain in 1997, pumping decreased to about $5 \mathrm{Mgal}$ in 1998, but gradually increased to $23 \mathrm{Mgal}$ in 2007.

Water Quality: Water from J-12 WW has compositions dominated by $\mathrm{Na}, \mathrm{K}$, and $\mathrm{HCO}_{3}$ (appendix B), reflecting flow through the volcanic aquifer. However, $\mathrm{Ca}$ and $\mathrm{Mg}$ are present in sufficient amounts to indicate that water has not interacted extensively with zeolitized tuffs. Extensive interaction would result in exchange of divalent alkali-earth cations from solution with monovalent alkali elements present in these altered tuffs. Concentrations of Ca in water from the J-12 WW welded-tuff aquifer typically range from 10 to $15 \mathrm{mg} / \mathrm{L}$, compared to less than $3 \mathrm{mg} / \mathrm{L}$ for water from WW-5C in Frenchman Flat that interacted with zeolitized tuffaceous alluvium (appendix B). Most sample data define a small cluster on a trilinear diagram, although several analyses show lower $\mathrm{Ca}$ contents and higher $\mathrm{Cl}$ than most other samples (appendix E, fig. E-6).

Specific conductance values measured during the 47-year period of record (April 1958 to October 2005) have remained constant (fig. 6). Most measurements are within analytical uncertainty ( \pm 5 percent) of the median value of $285 \mu \mathrm{S} / \mathrm{cm}$ (fig. 6B), regardless of the large differences in groundwater withdrawals during this period. Measured values range more widely in samples collected prior to increased withdrawals beginning in the early 1980s; however, MK and Sen's slope tests indicate no statistically significant trends with time (table 3; appendix D-2). Results of linear regression for specific conductance do not satisfy tests for normality.

Major ion concentrations in groundwater sampled from April 1958 to July 2006 vary beyond the range expected from analytical uncertainty alone; however, systematic trends with time generally are not apparent (fig. 7). Concentrations in the initial two water samples collected shortly after well completion in 1957 are commonly much different than subsequent samples and likely reflect contamination by drilling fluids that were not purged sufficiently until 1958. Trend analysis results confirm the absence of significant monotonic shifts in compositions with time except for $\mathrm{SiO}_{2}$ and $\mathrm{F}$, which show a small increase and decrease, respectively (table 3; appendix D-2). However, most of this variation is within the range expected for analytical uncertainty (fig. 7) and therefore does not constitute strong evidence for a systematic change in composition with time. Furthermore, large differences in pumping during different periods do not result in systematic changes in any of the major ion concentrations (ig. 7). Therefore, short term variations that may be present are not likely attributable to groundwater withdrawal.

Analyses of B, Li, Sr, and U were reported for J-12 WW water samples beginning in the late 1950s (appendix C). Large analytical uncertainties for early analyses are evident from the excessive scatter of resulting concentrations. For example, B concentrations ranged from 90 to 1,300 $\mu \mathrm{g} / \mathrm{L}$ in samples collected from 1957 to 1988 . However, the median B concentration of $135 \mu \mathrm{g} / \mathrm{L}$ for 12 samples reported for this period is within 4 percent of the median value of $130 \mu \mathrm{g} / \mathrm{L}$ for all 16 analyses reported through 2003, and within 1 percent of the mean value of $136 \mu \mathrm{g} / \mathrm{L}$ reported for the last two samples reported in 1997 and 2003. Concentrations of $U$ also remained uniform through time with median values of $0.60 \mu \mathrm{g} / \mathrm{L}$ for groundwater sampled between 1959 and 1971, and $0.61 \mu \mathrm{g} / \mathrm{L}$ for groundwater sampled between 1991 and 2003. 


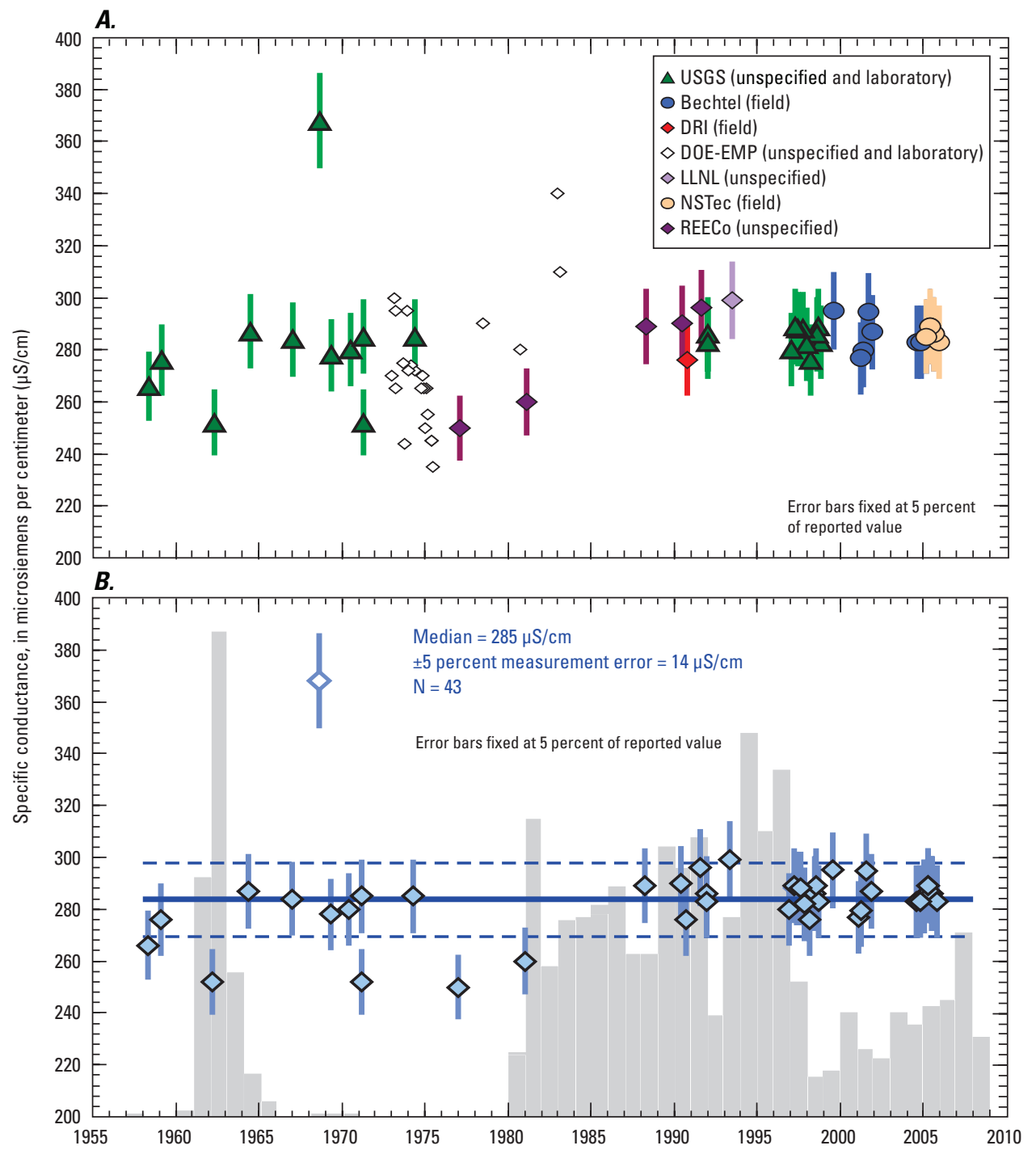

Figure 6. Temporal variations in specific conductance for water samples collected from J-12 WW, Nevada National Security Site, Nye County, Nevada. (A) All available specific conductance data from appendix A, identified by source including Bechtel, Bechtel Nevada; DOE-EMP, Department of Energy Environmental Monitoring Program; DRI, Desert Research Institute; LLNL, Lawrence Livermore National Laboratory; NSTec, National Security Technologies, LLC; REECo, Reynolds Electrical \& Engineering Co., Inc.; and USGS, U.S. Geological Survey. Reported measurements were either made in the field, the laboratory, or were unspecified in the database. $(B)$ Specific conductance data used to calculate the median value and trend analysis are shown as filled diamonds. Open symbols are outliers and were not included in numerical evaluations. Thick, horizontal blue line represents the median value shown along with estimates for 5 percent measurement error (dashed blue lines). Shaded histogram represents annual groundwater withdrawals from J-12 WW (see appendix E, fig. E-5 for withdrawal values). 

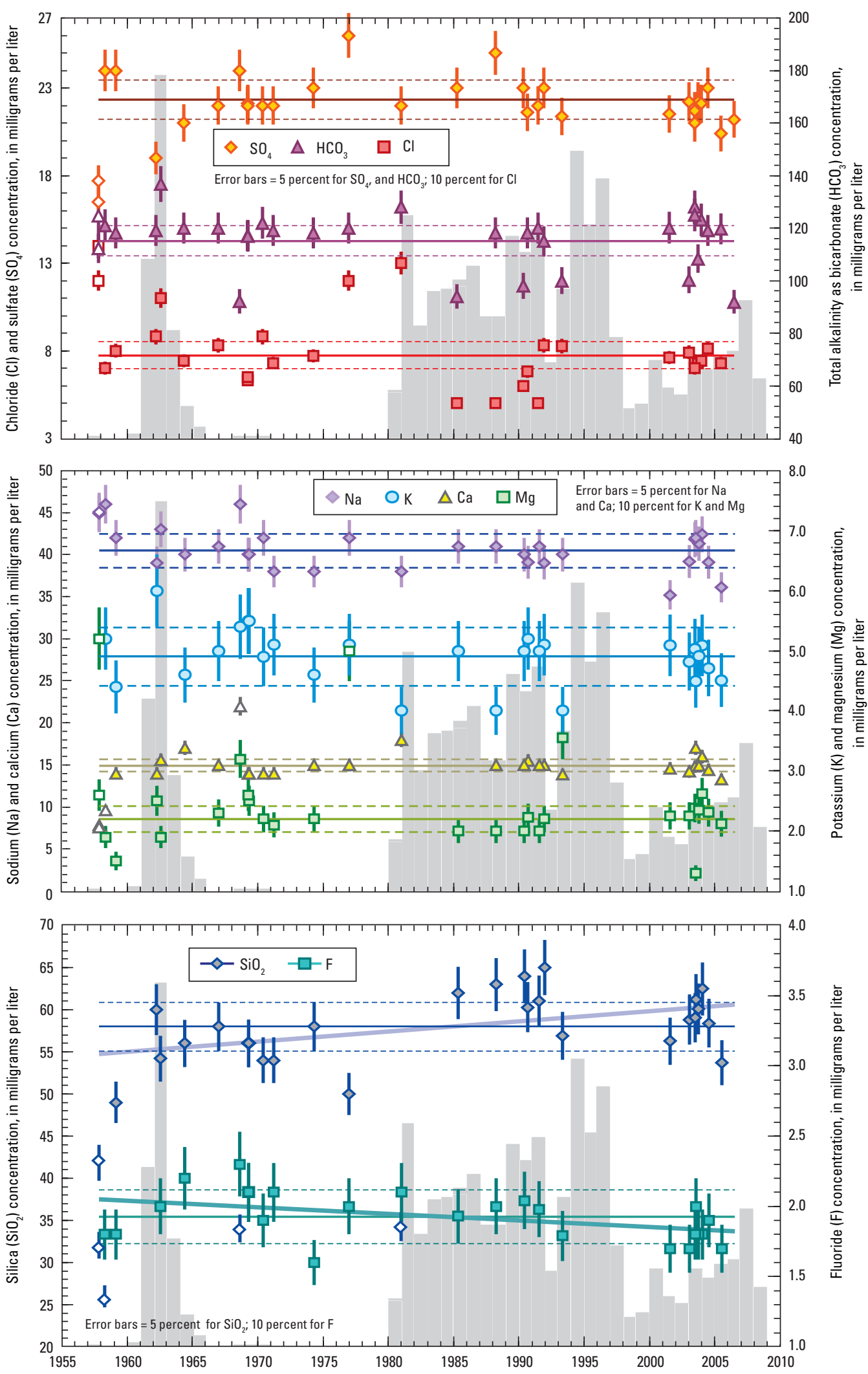

Figure 7. Temporal variations in major-ion concentrations for water samples collected from J-12 WW, Nevada National Security Site, Nye County, Nevada. Filled symbols represent data from appendix B used to calculate trend analyses and quantitative statistics (see results in appendix $\mathrm{D}$ and appendix $\mathrm{F}$, respectively). Open symbols represent outliers and were not included in numerical evaluations. Solid horizontal lines represent median concentration values shown along with estimated measurement error (dashed horizontal lines) using the same values given for error bars on individual analyses. Thick sloping lines represent statistically significant trends. Shaded histogram represents annual groundwater withdrawals from J-12 WW (see appendix E, fig. E-5 for withdrawal values). 
Analyses of $\delta^{2} \mathrm{H}$ and $\delta^{18} \mathrm{O}$ are available for groundwater sampled in 1971, 1991, and 1993 (appendix C). Values are near the high end of the range observed for NNSS waters ( -96 to $-97.5 \%$ for $\delta^{2} \mathrm{H}$ and -12.8 to $-13.1 \%$ for $\delta^{18} \mathrm{O}$; fig. 8). All three results are within analytical uncertainty. The relatively "heavy" (less negative) $\delta^{2} \mathrm{H}$ and $\delta^{18} \mathrm{O}$ values in these samples, along with elevated radiocarbon $\left({ }^{14} \mathrm{C}\right)$ concentrations (appendix C), are consistent with a larger component of local recharge in J-12 WW water relative to samples from many other wells on the NNSS. Ephemeral streamflow in Fortymile Wash (fig. 1) has been observed to infiltrate into streambed gravels, resulting in small rises in water levels in boreholes upgradient from J-12 WW in areas where depth to water is about $98 \mathrm{ft}$ (Osterkamp and others, 1994; Savard, 1998).

Table 3. Results of trend analyses for major constituents in water pumped from J-12 WW, Nevada National Security Site, Nye County, Nevada, between April 25, 1958, and July 25, 2006.

[A bbreviations: MK, Mann-Kendall test; SES, Sen's estimator of slope test; LR, linear regression; -, not applicable]

\begin{tabular}{lcccccc}
\hline \multicolumn{1}{c}{ Constituent } & $\begin{array}{c}\text { Total } \\
\text { samples }\end{array}$ & $\begin{array}{c}\text { Normality } \\
\text { tests }\end{array}$ & $\begin{array}{c}\text { MK } \\
\text { result }\end{array}$ & $\begin{array}{c}\text { SES } \\
\text { result }\end{array}$ & $\begin{array}{c}\text { Residual } \\
\text { normality } \\
\text { test }\end{array}$ & $\begin{array}{c}\text { LR } \\
\text { result }\end{array}$ \\
\hline Conductivity & 38 & failed & no trend & no trend & - & - \\
Calcium (Ca) & 26 & failed & no trend & no trend & - & - \\
Magnesium (Mg) & 27 & failed & no trend & no trend & - & - \\
Sodium (Na) & 29 & passed & no trend & no trend & passed & no trend \\
Potassium (K) & 28 & passed & decreasing & no trend & failed & - \\
Chloride (Cl) & 28 & failed & no trend & no trend & - & - \\
Bicarbonate $\left(\mathrm{HCO}_{3}\right)$ & 30 & failed & no trend & no trend & - & - \\
Sulfate (SO $)$ & 29 & failed & no trend & no trend & - & - \\
Silicon dioxide $\left(\mathrm{SiO}_{2}\right)$ & 26 & passed & increasing & increasing & passed & increasing \\
Fluoride $(\mathrm{F})$ & 25 & passed & decreasing & decreasing & passed & decreasing \\
\hline
\end{tabular}

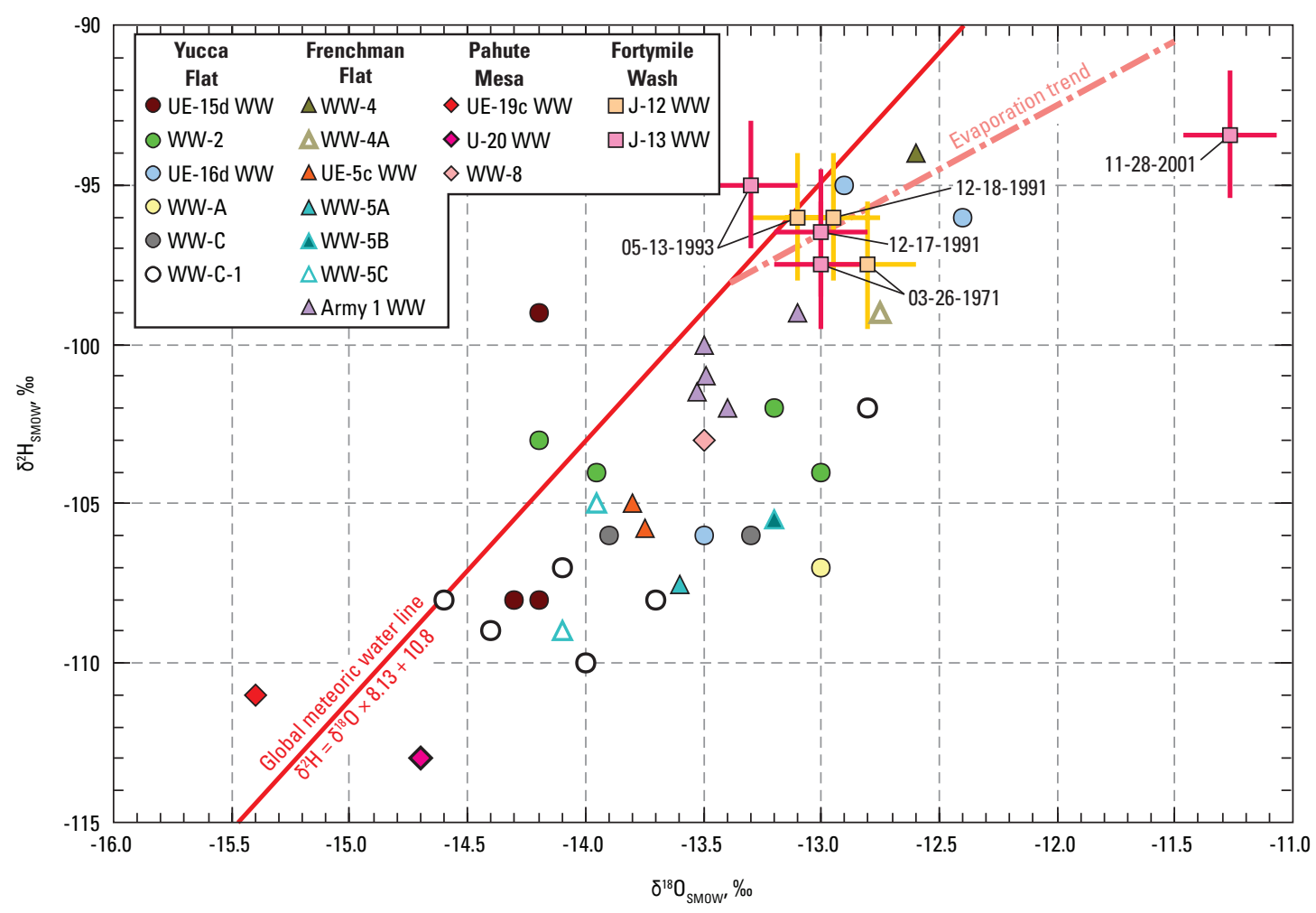

Figure 8. Isotopic compositions of hydrogen and oxygen for water samples collected from J-12 WW and $\mathrm{J}-13 \mathrm{WW}$ and data from other water-supply wells at the Nevada National Security Site, Nye County, Nevada. 


\section{J-13 WW}

Borehole Description and Water Withdrawals: J-13 WW is on the west edge of Jackass Flats in Area 25 of the NNSS, 2.9 mi north of J-12 WW (fig. 1; table 1). The borehole was drilled and completed to a depth of 3,488 ft in December 1962. The single completion in the borehole, well $J-13 W W$, is cased from land surface to a depth of 3,385 ft, with two perforated zones at 996-1,386 ft, and 2,690-3,312 ft (appendix E, fig. E-7). The annular space between the casing and borehole is open from 435 to about 1,390 ft and from $1,546 \mathrm{ft}$ to the bottom of the casing. The mean water level in the well is at a depth of $928 \mathrm{ft}$ below land surface.

The borehole penetrates alluvium from 0 to $425 \mathrm{ft}$, followed by alternating layers of welded and nonwelded tuffs from 425 to 3,488 ft. The upper perforated zone is open to densely welded and fractured Topopah Spring Tuff of the Paintbrush Group. The lower perforated zone is open mostly to the partly welded and commonly zeolitized Tram unit of the Crater Flat Tuff (Thordarson, 1983, table 4). Water produced from the well is mostly from secondary fracture permeability within the Topopah Spring Tuff, which has high transmissivity and hydraulic conductance (Thordarson, 1983, p. 20). This tuff unit is included within the Paintbrush volcanic-rock aquifer HSU. Tuffs intersected by the lower perforated zone have much lower transmissivities and are considered to be confining beds within the older volcanic-rock unit HSU.

$\mathrm{J}-13 \mathrm{WW}$, originally drilled to investigate groundwater flow through carbonate rocks underlying Jackass Flats (Thordarson, 1983, p. 2), never reached the base of the
Tertiary volcanic-rock section. The well subsequently was used to supply water for the Nuclear Rocket Development Station in Jackass Flats from 1964 to 1967 (Young, 1972; Thordarson, 1983), and later to supply water for site characterization and construction activities associated with the Yucca Mountain nuclear waste isolation project from 1982 to 2006. More than 1,320 Mgal of water have been withdrawn from the well since 1962 (appendix E, fig. E-8). An estimated 710 Mgal of water were withdrawn from 1964 to 1967 followed by a 14-year period of inactivity (Elliott and Moreo, 2011). After reinitiation of Area 25 work activities in 1982, about $611 \mathrm{Mgal}$ of water were withdrawn through 2006. The pump was shut off in 2006 and the well was deactivated in October 2008.

Water Quality: Water from J-13 WW has compositions dominated by $\mathrm{Na}$ and $\mathrm{HCO}_{3}$ (appendix B), which reflects flow through welded tuffs of the Paintbrush volcanic-rock aquifer. Compositions are similar to those present in water from J-12 WW and plot in a small cluster on a trilinear diagram (appendix E, fig. E-9). Specific conductance values measured over a 43-year period (1963-2005) have a median value of $285 \mu \mathrm{S} / \mathrm{cm}$ (fig. 9). Most measurements are within the expected error limits ( \pm 5 percent) of the median value. However, some scatter is observed both below (earlier samples) and above (later samples) the median value. Nonparametric tests indicate that no statistically significant trends are present for specific conductance measurements (table 4; appendix D-3). However, differences between pre- and post-1985 periods are significant at the 95-percent confidence level determined using both parametric

Table 4. Results of trend analyses for major constituents in water pumped from J-13 WW, Nevada National Security Site, Nye County, Nevada, between January 1963 and October 2005.

[A bbreviations: MK, Mann-Kendall test; SES, Sen's estimator of slope test; LR, linear regression; -, not applicable]

\begin{tabular}{lcllccc}
\hline \multicolumn{1}{c}{ Constituent } & $\begin{array}{c}\text { Total } \\
\text { samples }\end{array}$ & $\begin{array}{c}\text { Normality } \\
\text { tests }\end{array}$ & $\begin{array}{c}\text { MK } \\
\text { result }\end{array}$ & $\begin{array}{c}\text { SES } \\
\text { result }\end{array}$ & $\begin{array}{c}\text { Residual } \\
\text { normality } \\
\text { test }\end{array}$ & $\begin{array}{c}\text { LR } \\
\text { result }\end{array}$ \\
\hline Conductivity & 28 & failed & no trend & no trend & - & - \\
Calcium $(\mathrm{Ca})$ & 16 & passed & decreasing & decreasing & passed & decreasing \\
Magnesium $(\mathrm{Mg})$ & 16 & failed & decreasing & decreasing & - & - \\
Sodium $(\mathrm{Na})$ & 15 & inconclusive & no trend & no trend & failed & - \\
Potassium $(\mathrm{K})$ & 16 & passed & decreasing & decreasing & passed & decreasing \\
Chloride $(\mathrm{Cl})$ & 15 & inconclusive & no trend & no trend & passed & no trend \\
Bicarbonate $\left(\mathrm{HCO}_{3}\right)$ & 16 & failed & decreasing & decreasing & - & - \\
Sulfate $\left(\mathrm{SO}_{4}\right)$ & 13 & passed & no trend & no trend & passed & no trend \\
Silicon dioxide $\left(\mathrm{SiO}_{2}\right)$ & 16 & passed & no trend & no trend & failed & - \\
Fluoride $(\mathrm{F})$ & 15 & passed & no trend & no trend & passed & no trend \\
\hline
\end{tabular}




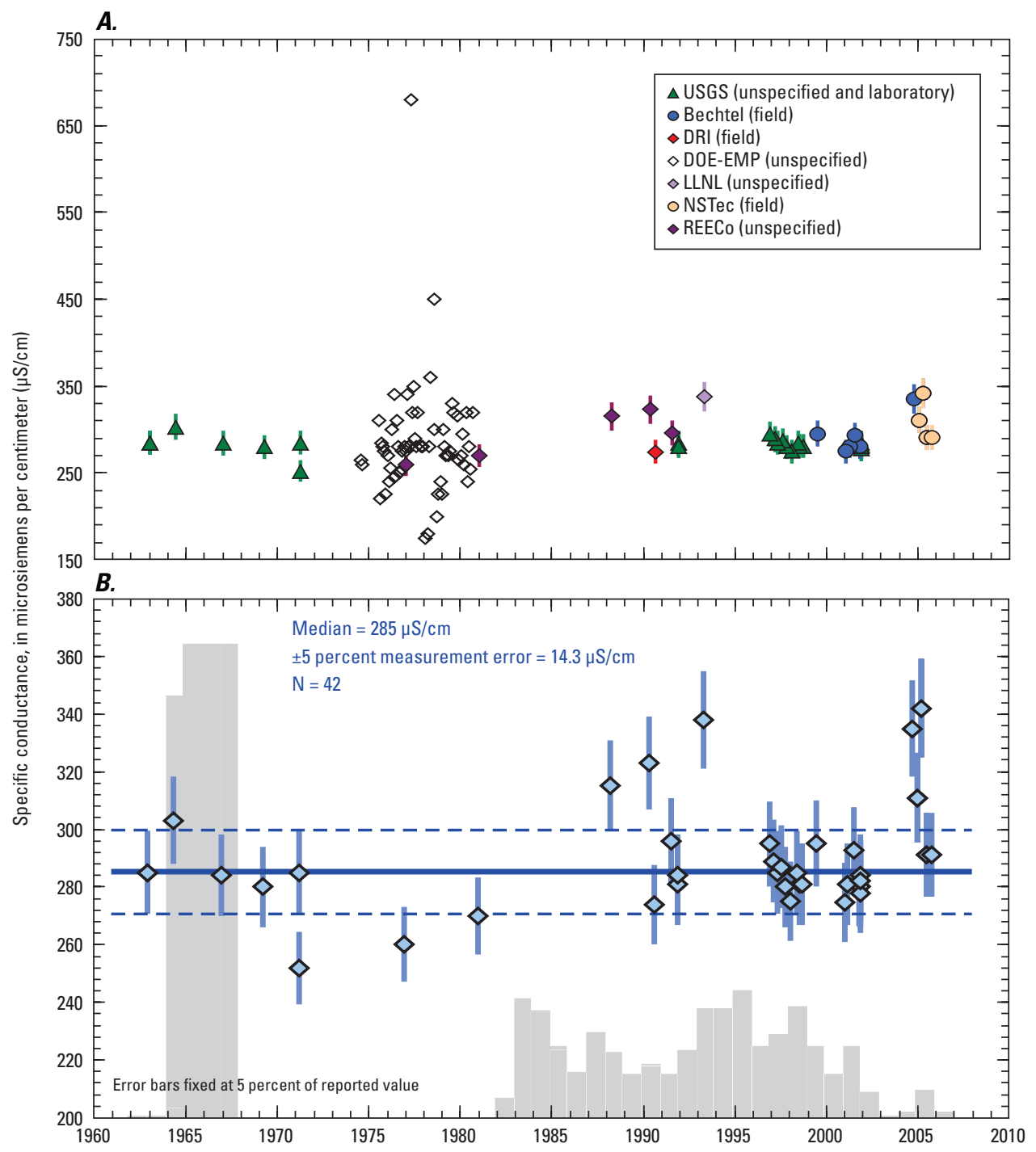

Figure 9. Temporal variations in specific conductance for water samples collected from J-13 WW, Nevada National Security Site, Nye County, Nevada. (A) All available specific conductance data from appendix A, identified by source including Bechtel, Bechtel Nevada; DOE-EMP, Department of Energy Environmental Monitoring Program; DRI, Desert Research Institute; LLNL, Lawrence Livermore National Laboratory; NSTec, National Security Technologies, LLC; REECo, Reynolds Electrical \& Engineering Co., Inc.; and USGS, U.S. Geological Survey. Reported measurements were either made in the field, laboratory, or were unspecified in the database. $(B)$ Specific conductance data used to calculate the median value and trend analysis. Thick, horizontal blue line represents median value shown along with estimates for 5 percent measurement error (dashed blue lines). Shaded histogram represents annual groundwater withdrawals from J-13 WW (see appendix E, fig. E-8 for withdrawal values). 
(2-sample t) and nonparametric (Mann-Whitney) tests. This outcome is largely dependent on three measurements with values of 335-342 $\mu \mathrm{S} / \mathrm{cm}$ made in 1993, 2004, and 2005 that are interspersed among a larger number of lower values determined during the same period. If these values represent analytical outliers, no statistically significant differences are present between earlier and later samples. Furthermore, the median value for all J-13 WW data $(285 \mu \mathrm{S} / \mathrm{cm})$ is identical to the median value determined for nearby J-12 WW data (fig. 6). Systematic differences in specific conductance measured during periods of high pumping rates (middle 1960s) compared to low pumping rates (1982-2005) are not apparent (fig. 9). Cumulatively, these results are interpreted as evidence that specific conductance in J-13 WW has not varied systematically throughout the withdrawal history of the well.

Major ion concentrations in J-13 WW groundwater sampled from 1963 to 2005 commonly are within the range expected from analytical uncertainty about the overall median values (fig. 10). However, differences in concentration for several constituents between the early period of high volume pumping (1960s) and samples analyzed after 1990, indicate that small shifts with time may be significant. In particular, trend analysis of $\mathrm{Ca}, \mathrm{Mg}$, and $\mathrm{HCO}_{3}$ data indicate that all three constituents may have decreased with time (table 4; appendix D-3), although much of this variation is within the range anticipated from analytical uncertainty. These results are consistent with a gradual decrease in a calcium carbonaterich component within J-13 WW groundwater over time. Nonparametric and linear regressions also indicate a decrease in $\mathrm{K}$ over time; however, these results are strongly influenced by two samples from 1993 and 2005. If these two analyses represent outliers, no overall trend is obtained. Concentrations of other major ions characteristic of the volcanic aquifer ( $\mathrm{Na}, \mathrm{Cl}, \mathrm{SiO}_{2}$, and $\mathrm{F}$ ), as well as $\mathrm{SO}_{4}$, show no overall trends with time.

Analyses of As, B, Li, Mn, Se, Sr, U, and Zn were reported for groundwater sampled from the early 1960s (appendix C), although Mn, Se, and Zn data were measured imprecisely. However, As, B, Li, and U reported for samples pumped in the 1960s and 1970s are similar to values reported in the 1990s and 2000s. More reliable measurements of $\mathrm{Ba}, \mathrm{Mn}, \mathrm{Mo}, \mathrm{Sr}$, and U since the 1990s are typically more consistent, with concentrations close to or within analytical error of mean values (fig. 11A)
Four sets of $\delta^{2} \mathrm{H}$ and $\delta^{18} \mathrm{O}$ analyses are available for J-13 WW groundwater sampled in 1971, 1991, 1993, and 2001 (appendix C). Values are near the high end of the range for NNSS waters ( -93.4 to $-97.5 \%$ for $\delta^{2} \mathrm{H}$ and -11.3 to $-13.3 \%$ for $\delta^{18} \mathrm{O}$; fig. 8). The three earlier samples are statistically identical to each other and to values measured in J-12 WW. Although the $\delta^{2} \mathrm{H}$ value of the 2001 analysis is also statistically identical to the other samples, its $\delta^{18} \mathrm{O}$ is much less negative ("heavier"). As a consequence, the 2001 sample plots far to the right of the global meteoric water line (fig. 8). Evaporation of the 2001 sample under low relative humidity, either before or after the sample was collected, might help explain the much heavier $\delta^{18} \mathrm{O}$ value in this sample; however, it does not fall along an evaporation trend line expected to have a slope between 4 and 8 (compositions within the area between dash-dot line and global meteoric line in fig. 8). Interpretation of this analysis is further complicated because its ${ }^{14} \mathrm{C}$ concentration (33.5 percent modern carbon; appendix C) is slightly higher than earlier samples (29.2 and 29.8 percent modern carbon). These data are consistent with a larger component of modern local recharge in the 2001 sample. However, similarly high ${ }^{14} \mathrm{C}$ concentrations were determined in J-12 WW samples collected in 1971 and 1991. Therefore, it is likely that the anomalous oxygen-hydrogen isotope data reported for the 2001 sample represents an analytical artifact rather than a real shift in composition.

Isotopic compositions of $\mathrm{Sr}\left({ }^{87} \mathrm{Sr} /{ }^{86} \mathrm{Sr}\right.$ atomic ratio) and $U\left({ }^{234} U /{ }^{238} U\right.$ activity ratio) have been reported for J-13 WW samples since late 1988 (fig. 11B). These heavy radiogenic isotopes are not affected by mineral precipitation or evaporation and can be used as natural isotopic tracers of different water sources (Peterman and others, 1992; Bullen and Kendall, 1998; Johnson and others, 2000; Paces and others, 2002). Available ${ }^{87} \mathrm{Sr} /{ }^{86} \mathrm{Sr}$ and ${ }^{234} \mathrm{U} /{ }^{238} \mathrm{U}$ data show a narrow range in compositions from 1988 to 2001 that is beyond the range expected for analytical error. Strontium isotopic compositions were lowest in samples from 1988 and 1989, and then remained constant (within analytical uncertainty) between 1991 and 2001. In contrast, U isotopic compositions were highest in 1988 and 1991 followed by a shift to slightly lower values from 1996 to 2001. Large differences in water usage were not observed during the 1990s. Little compositional variation in $\mathrm{Sr}$ and $\mathrm{U}$ isotope ratios and the absence of correlations between the two isotope ratios (fig. 11C), or with withdrawal history, are interpreted as evidence that sources constituting water pumped from J-13 WW largely remained uniform during this period. 

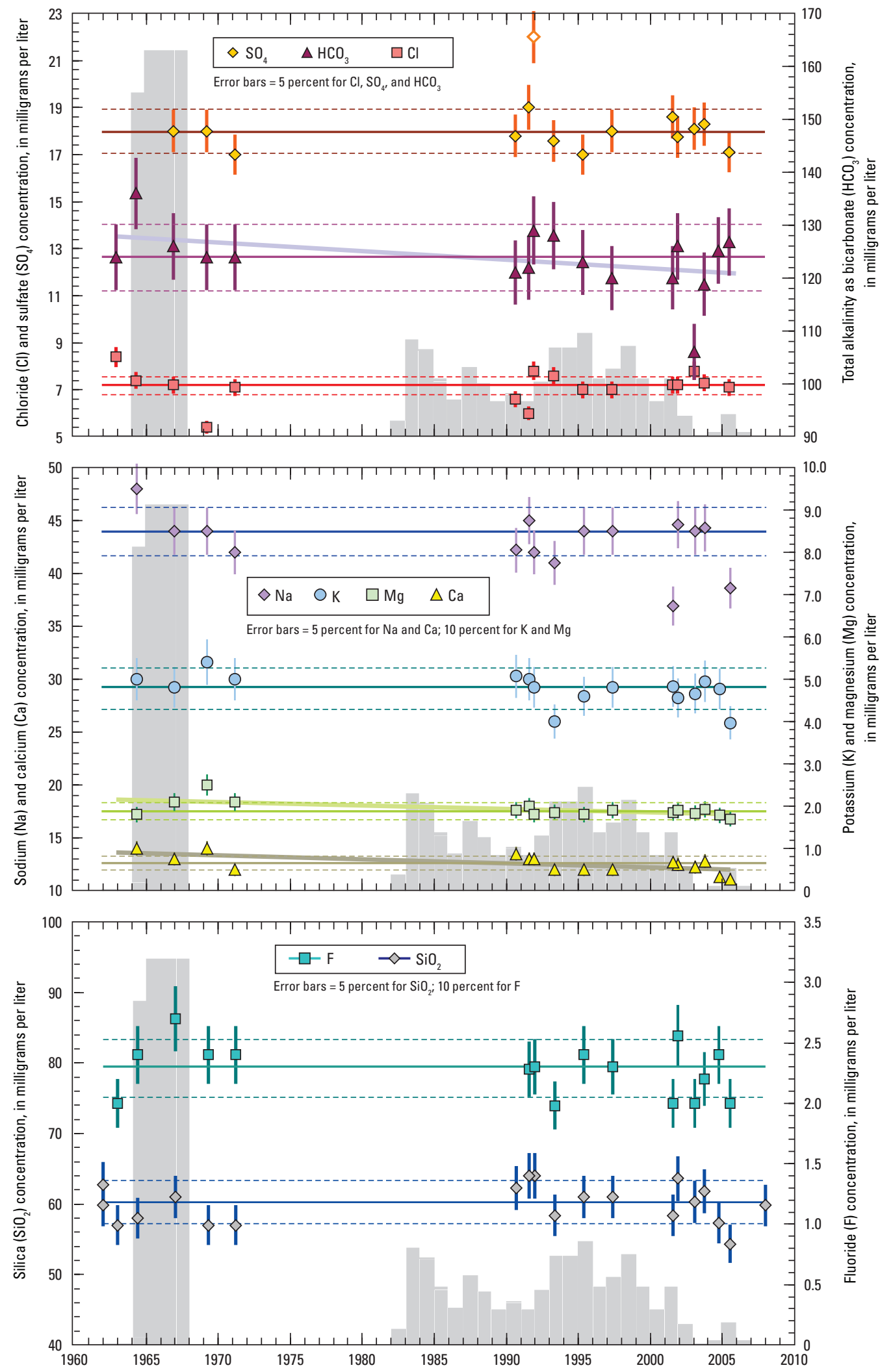

Figure 10. Temporal variations in major-ion concentrations for water samples collected from J-13 WW, Nevada National Security Site, Nye County, Nevada. Filled symbols represent data from appendix B used to calculate trend analyses and quantitative statistics (see results in appendix $\mathrm{D}$ and appendix $\mathrm{F}$, respectively). Open symbols represent outliers and were not included in numerical evaluations. Solid horizontal lines represent median concentration values shown along with estimated measurement error (dashed horizontal lines) using the same values given for error bars on individual analyses. Thick sloping lines represent statistically significant trends. Shaded histogram represents annual groundwater withdrawals from J-13 WW (see appendix E, fig. E-8 for withdrawal values). 


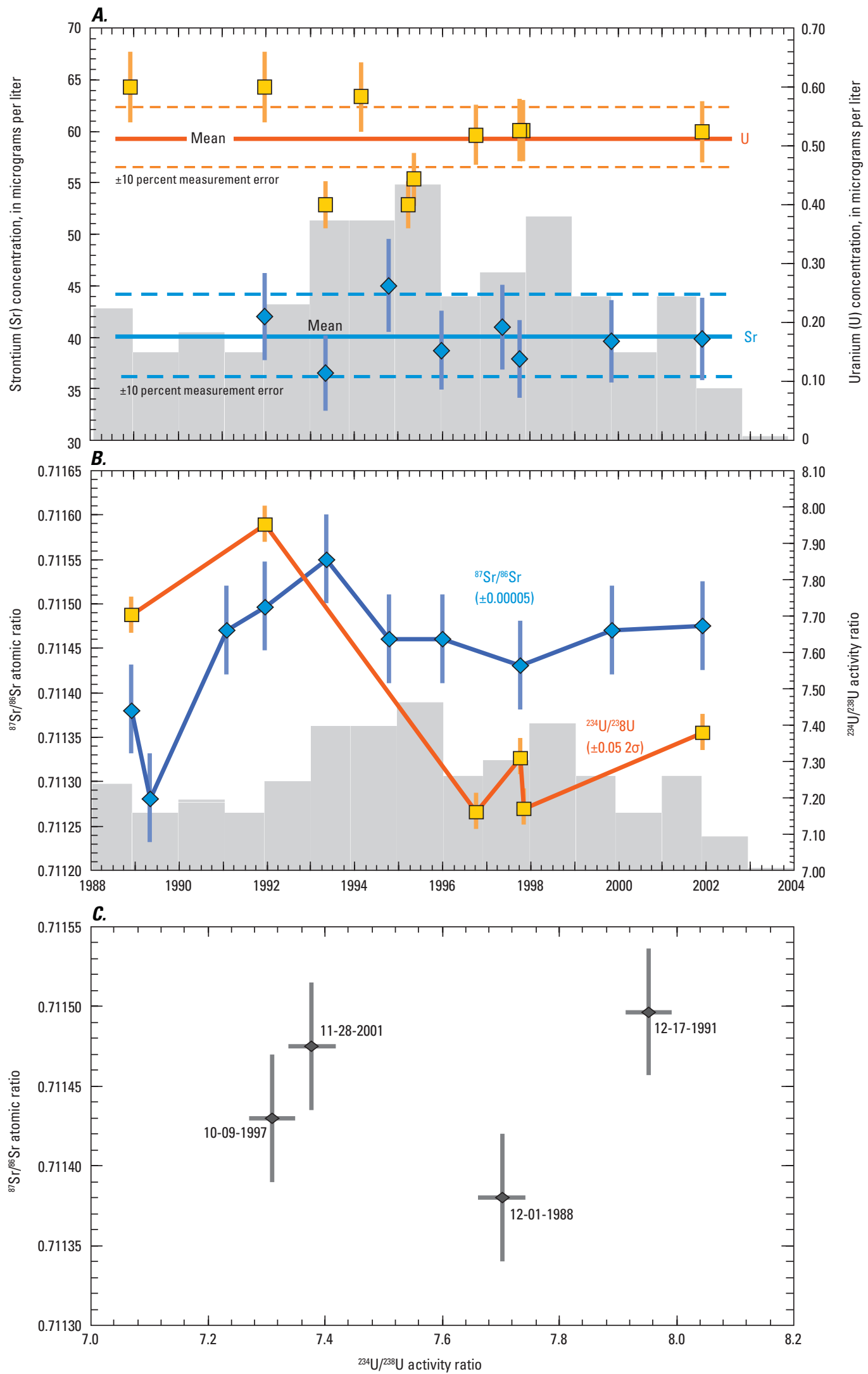

Figure 11. Temporal variations in $(A)$ concentration and $(B)$ isotopic compositions of strontium $(\mathrm{Sr})$ and uranium $(U)$, and (C) correlations between $\mathrm{Sr}$ and U isotope ratios in water samples collected from J-13 WW, Nevada National Security Site, Nye County, Nevada. Solid and dashed lines in $(A)$ represent mean values and estimated analytical uncertainties, respectively. 


\section{U-20 WW}

Borehole Description and Water Withdrawals: U-20 WW is on Pahute Mesa in Area 20 of the NNSS (fig. 1; table 1). The borehole was drilled and completed to a depth of 3,268 ft in July 1982. The single completion in the borehole, well $U-20 W W$ (cased), is cased to a depth of 3,199 ft and has a slotted interval from 2,271 to 3,035 ft (appendix E, fig. E-10). The annular space between the casing and borehole is open below a depth of $65 \mathrm{ft}$. The mean water level in the well is at a depth of about 2,053 ft below land surface.

The borehole penetrates a thick sequence of alternating layers of welded and nonwelded tuffs from 0 to $1,444 \mathrm{ft}$ that are underlain by a series of lava, flow breccia, and nonwelded tuffs from 1,444 to 3,260 ft (appendix E, fig. E-10; Warren and others, 2003; Wood, 2007). Most water from the well is produced from fractured rhyolite lava flows (Gillespie and others, 1996, p. 55), present in the lower part of the perforated zone from about 2,830 to 3,000 ft below land surface (Warren and others, 2003; Wood, 2007). These units are included in the Calico Hills zeolitic composite unit HSU.

U-20 WW has been used primarily as a water supply for construction (Wood and Reiner, 1996, p. 8). Pumping began in July 1985 and continued through May 1996 (appendix E, fig. E-11). After that, pumping was sporadic. Almost $775 \mathrm{Mgal}$ of water have been withdrawn from the well since 1985, of which 94 percent was withdrawn from 1985 to 1996.

Water Quality: Water from well U-20 WW has a composition dominated by $\mathrm{Na}$ and $\mathrm{HCO}_{3}$ ions (appendix B), typical of groundwater flowing through volcanic aquifers. Analyses form a tight cluster on a trilinear plot of major ions (appendix E, fig. E-12). Alkali-earth elements (Ca and $\mathrm{Mg}$ ) are very low and indicate extensive cation exchange of groundwater with zeolitized nonwelded tuff that is interbedded with rhyolite lavas. Although $\mathrm{HCO}_{3}$ is the dominant anion, $\mathrm{SO}_{4}$ and lesser $\mathrm{Cl}$ are significant (approximately $30-40$ percent of the total anions). Specific conductance measured over a 10-year period spanning most of the production period (May 1987 to November 1997) remained uniform, with a median value of $298.5 \mu \mathrm{S} / \mathrm{cm}$ (fig. 12). Most measurements are within expected error limits ( \pm 5 percent) of the median value despite the variations in annual withdrawals.

Major ion concentrations in water from U-20 WW commonly are within the range expected for analytical uncertainty of their median values (fig. 13). Only six samples of water from the well were analyzed over a 10 -year period, which compromises the reliability of statistical tests of trend. Nevertheless, resulting analyses (table 5; appendix D-4) indicate that major ion compositions remained uniform with time with the possible exception of $\mathrm{Cl}$, which may show a small decrease based on nonparametric trend tests. Nonparametric test results for $\mathrm{HCO}_{3}$ are mixed; however, the decreasing trend indicated by Sen's estimator of slope is largely a consequence of low concentrations in samples collected on May 31, 1995. $\mathrm{HCO}_{3}$ concentrations for the next available sample (November 1997) were similar to values obtained in the late 1980s and early 1990s. Therefore, the limited amount of data from U-20-WW that exhibit little compositional variability are interpreted as evidence that major ion concentrations remained uniform throughout the period of pumping from 1987 to 1997.

Only a small number of trace element concentrations are available for samples from U-20 WW (appendix C), making it difficult to evaluate temporal variation. $U$ data provides the only reliable comparison of analyses for three samples collected in $1991(2.33 \mu \mathrm{g} / \mathrm{L}), 1995(2.0 \mu \mathrm{g} / \mathrm{L})$, and 1997 (average value of $2.19 \mu \mathrm{g} / \mathrm{L}$ ). These differences in U concentration represent a total deviation of about 15 percent, which is likely within error overlap of interlaboratory analytical uncertainty (the average for the November 5, 1997, sample alone is based on reported values of 2.11, 2.15, and $2.30 \mu \mathrm{g} / \mathrm{L}$ ). These few data do not indicate any systematic shifts in $\mathrm{U}$ concentration.

Analyses of $\delta^{2} \mathrm{H}$ and $\delta^{18} \mathrm{O}$ are available only for one sample collected in 1997 (appendix C). Values of -113 for $\delta^{2} \mathrm{H}$ and -14.7 for $\delta^{18} \mathrm{O}$ are some of the "lightest" (most negative) isotopic compositions obtained from NNSS groundwater (fig. 14). These "light" values are consistent with (1) recharge derived at higher latitudes north of the NNSS (implying long flow paths); (2) old (Pleistocene) recharge under colder temperature conditions (compared to "heavier" values for nearby WW-8 in figure 14, which contains a larger component of modern recharge); or (3) a combination of old recharge from higher latitudes.

Low ${ }^{14} \mathrm{C}$ concentrations of 9.1 and 8.6 percent modern carbon (appendix C) are consistent with both of these scenarios. Strontium isotopic compositions $\left({ }^{87} \mathrm{Sr} /{ }^{86} \mathrm{Sr}\right)$ were determined for samples collected in 1991, 1995, and 1997 (appendix C). The three individual determinations are nearly within measurement error of the mean value of 0.71126 (fig. 15). Cumulatively, these major ion, trace element, and isotope data strongly support the conclusion that water pumped from U-20 WW remained compositionally uniform throughout the main period of groundwater withdrawal and into the more recent period of low volume pumping. 


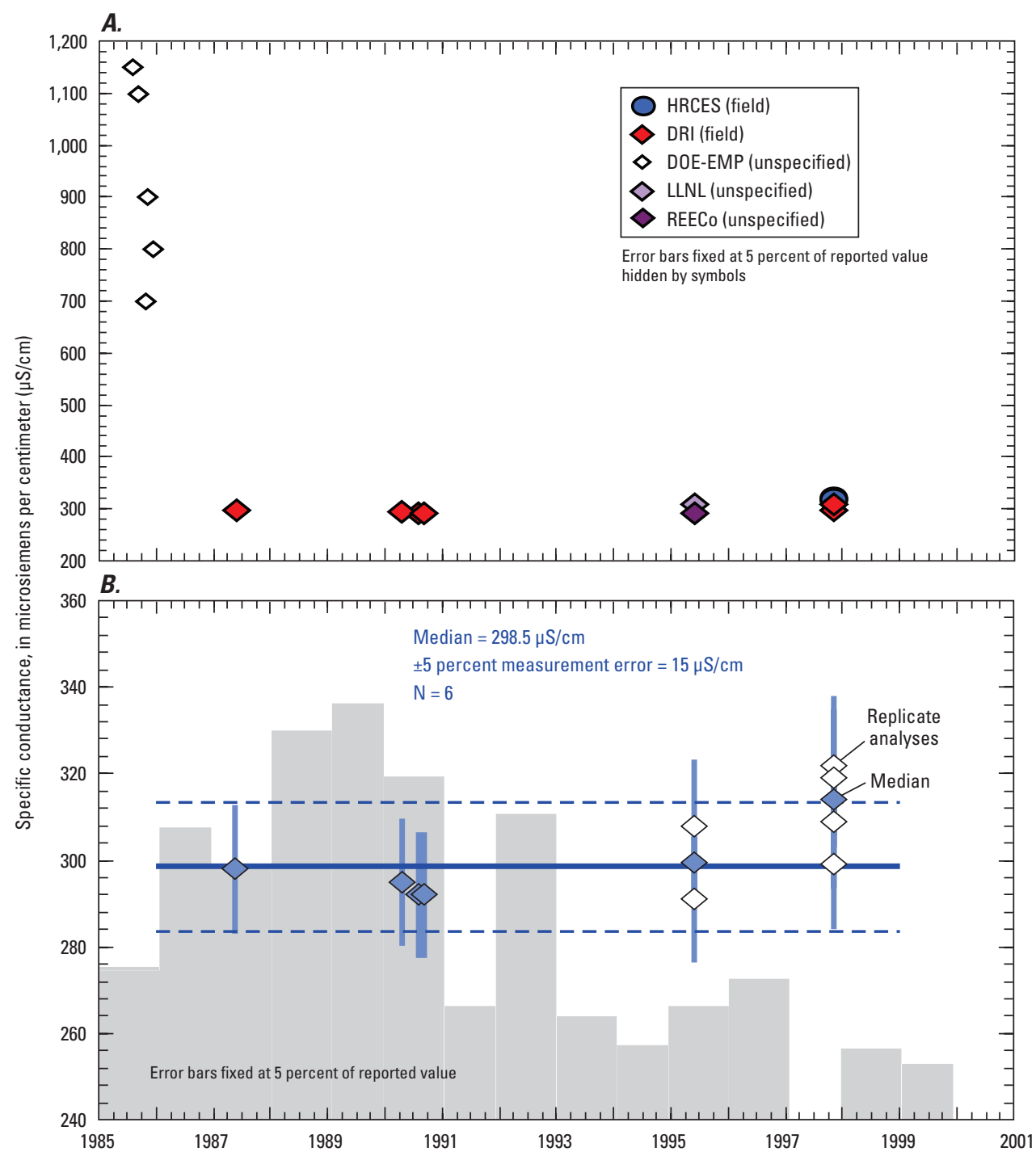

Figure 12. Temporal variations in specific conductance for water samples collected from U-20 WW, Nevada National Security Site, Nye County, Nevada. (A) All available specific conductance data from appendix $A$, identified by source including DOE-EMP, Department of Energy Environmental Monitoring Program; DRI, Desert Research Institute; HRCES, Harry Reid Center for Environmental Studies; LLNL, Lawrence Livermore National Laboratory; and REECo, Reynolds Electrical \& Engineering Co., Inc. Reported measurements were either made in the field, the laboratory, or were unspecified in the database. $(B)$ Specific conductance data used to calculate the median value and trend analysis are shown as filled diamonds. Open symbols represent multiple analyses for a single sampling event that were used to calculate the mean value for that event (shown as a filled diamond for the same date). Thick, horizontal blue line represents median value shown along with estimates for 5 percent measurement error (dashed blue lines). Shaded histogram represents annual groundwater withdrawals from U-20 WW (see appendix E, fig. E-11 for withdrawal values). 

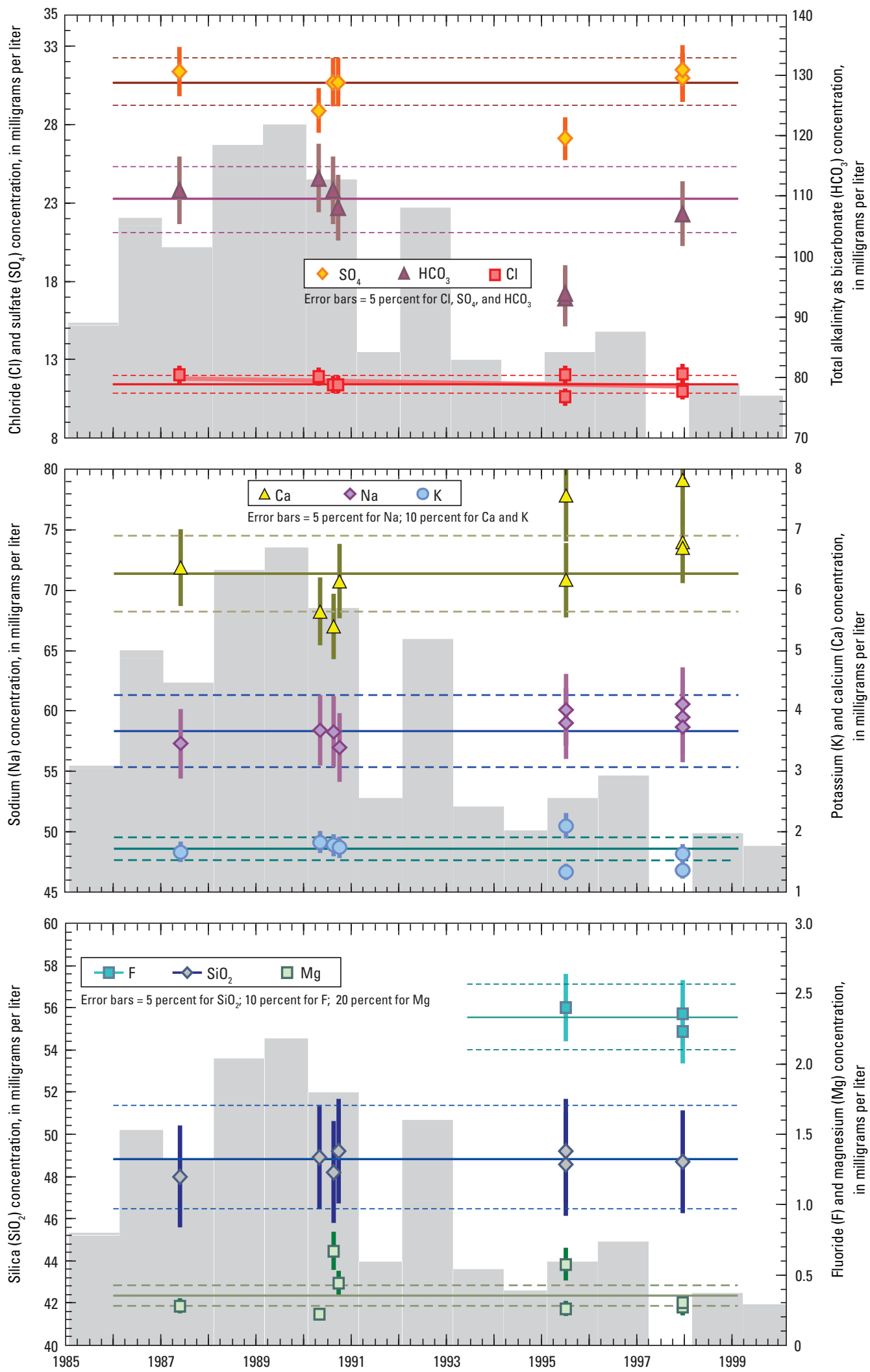

Figure 13. Temporal variations in major-ion concentrations for water samples collected from U-20 WW, Nevada National Security Site, Nye County, Nevada. Filled symbols represent data from appendix B used to calculate trend analyses and quantitative statistics (see results in appendix D and appendix F, respectively). Solid horizontal lines represent median concentration values shown along with estimated measurement error (dashed horizontal lines) using the same values given for error bars on individual analyses. Thick sloping line for $\mathrm{Cl}$ represents a statistically significant trend. Shaded histogram represents annual groundwater withdrawals from $\mathrm{U}-20 \mathrm{WW}$ (see appendix E, fig. E-11 for withdrawal values). 
Table 5. Results of trend analyses for major constituents in water pumped from U-20 WW, Nevada National Security Site, Nye County, Nevada, between May 23, 1987, and November 5, 1997.

[A bbreviations: MK, Mann-Kendall test; SES, Sen's estimator of slope test; LR, linear regression; -, not applicable]

\begin{tabular}{lclllll}
\hline \multicolumn{1}{c}{ Constituent } & $\begin{array}{c}\text { Total } \\
\text { samples }\end{array}$ & \multicolumn{1}{c}{$\begin{array}{c}\text { Normality } \\
\text { tests }\end{array}$} & $\begin{array}{c}\text { MK } \\
\text { result }\end{array}$ & $\begin{array}{c}\text { SES } \\
\text { result }\end{array}$ & $\begin{array}{c}\text { Residual } \\
\text { normality } \\
\text { test }\end{array}$ & $\begin{array}{c}\text { LR } \\
\text { result }\end{array}$ \\
\hline Conductivity & 6 & passed & no trend & no trend & passed & no trend \\
Calcium $(\mathrm{Ca})$ & 6 & passed & no trend & no trend & passed & no trend \\
Magnesium $(\mathrm{Mg})$ & 6 & passed & no trend & no trend & passed & no trend \\
Sodium $(\mathrm{Na})$ & 6 & passed & no trend & no trend & passed & no trend \\
Potassium $(\mathrm{K})$ & 6 & passed & no trend & no trend & passed & no trend \\
Chloride $(\mathrm{Cl})$ & 6 & inconclusive & decreasing & decreasing & passed & no trend \\
Bicarbonate $\left(\mathrm{HCO}_{3}\right)$ & 6 & failed & no trend & decreasing & - & - \\
Sulfate $\left(\mathrm{SO}_{4}\right)$ & 6 & passed & no trend & no trend & passed & no trend \\
Silicon dioxide $\left(\mathrm{SiO}_{2}\right)$ & 6 & passed & no trend & no trend & passed & no trend \\
Fluoride $(\mathrm{F})$ & 2 & insufficient data & insufficient data & insufficient data & insufficient data insufficient data \\
\hline
\end{tabular}

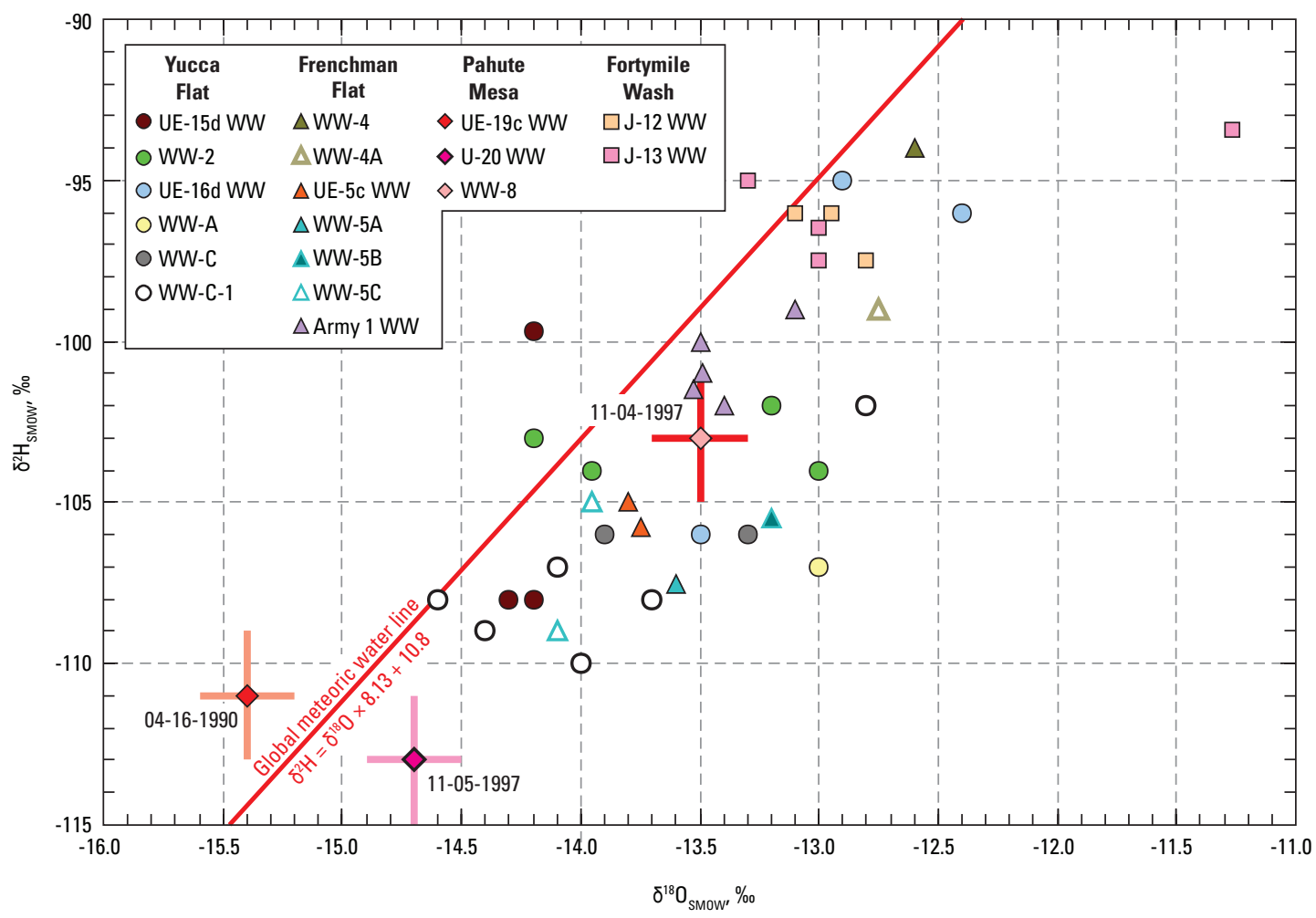

Figure 14. Isotopic compositions of hydrogen and oxygen for water samples collected from U-20 WW, UE-19c WW, and WW-8 and data from other water-supply wells at the Nevada National Security Site, Nye County, Nevada. 


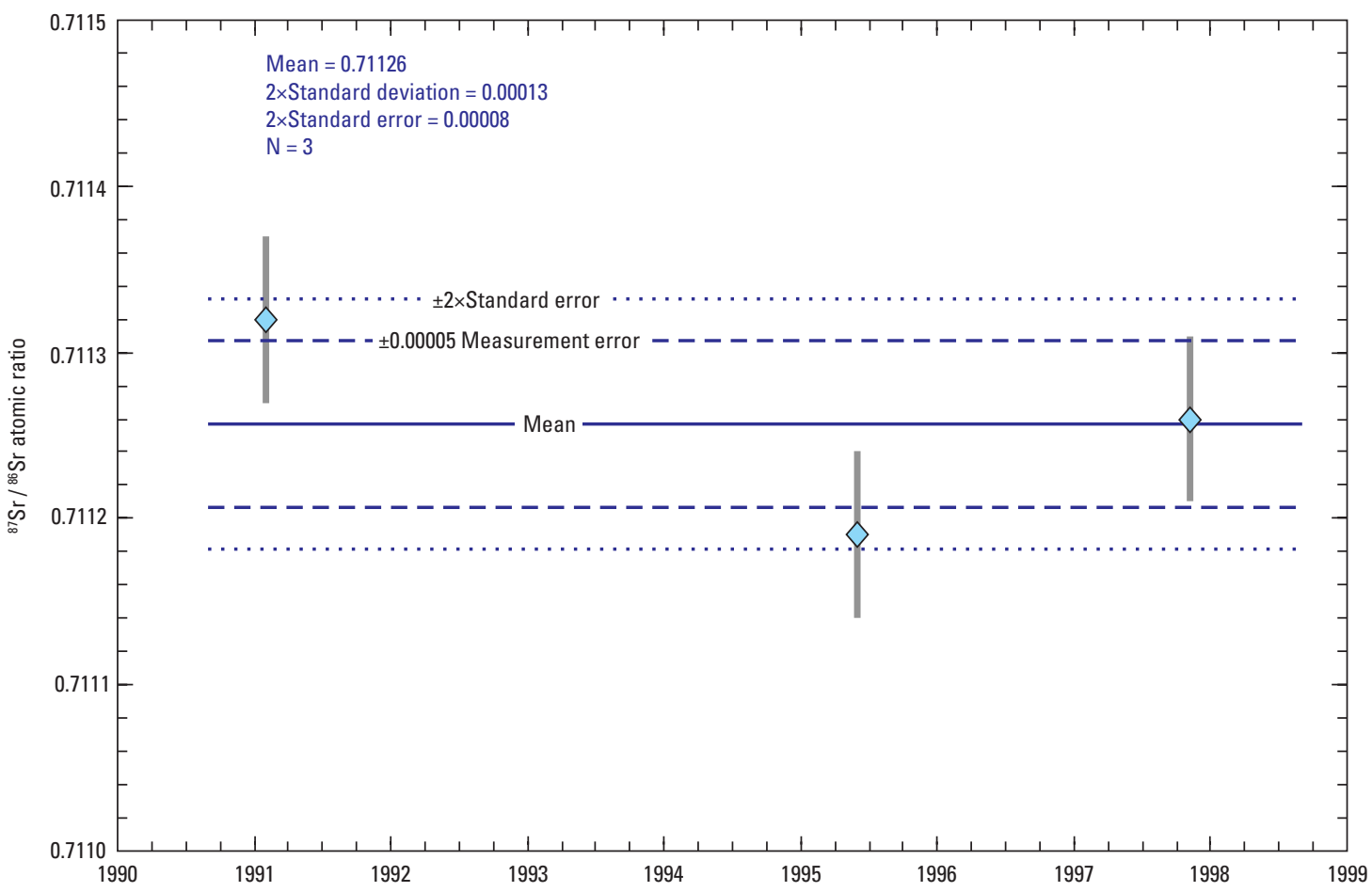

Figure 15. Temporal variations in strontium isotopic compositions of water samples collected from U-20 WW (cased), Nevada National Security Site, Nye County, Nevada. 


\section{UE-5c WW}

Borehole Description and Water Withdrawals: UE-5c WW is in Frenchman Flat in Area 5 of the NNSS (fig. 1; table 1). The borehole was drilled to a depth of 2,682 ft in November 1964, and was completed as a supply well in April 1966. The single completion in the borehole, well $U E-5 c W W$, is cased to a depth of $1,682 \mathrm{ft}$, with perforations from 1,100 to $1,300 \mathrm{ft}$. The annular space between the casing and borehole is open from 77 to 1,300 ft (appendix E, fig. E-13). The well is uncased from 1,682 to 2,682 ft. The mean water level in the well is at a depth of $807 \mathrm{ft}$ below land surface.

The borehole penetrates alluvium from 0 to $1,300 \mathrm{ft}$, and tuff breccia, flow breccia, and welded tuff below the alluvium (fig. E-13). Most of the water produced from the well likely originates from the alluvium from either the younger or older alluvial aquifer HSU (AA3 and AA2, respectively). Only minor amounts of water likely are derived from the underlying tuff units (Gillespie and others, 1996, p. 20), which are included in the lower tuff confining unit HSU.

UE-5c WW was drilled as an exploratory hole and later was used as a supply well for activities in Frenchman Flat. It is estimated that more than $153 \mathrm{Mgal}$ of water have been withdrawn from the well since 1967 (fig. E-14); 99 percent of the water was withdrawn prior to 1999 (Elliott and Moreo, 2011).

Water Quality: Water from UE-5c WW has compositions dominated by $\mathrm{Na}$ and $\mathrm{HCO}_{3}$ ions (appendix B), consistent with the dominance of volcanic lithologies that constitute the local alluvial aquifer. Sample concentrations form a tight cluster on a trilinear plot of major ions (appendix E, fig. E-15). The low concentrations of alkali-earth elements ( $\mathrm{Ca}$ and $\mathrm{Mg}$ ) indicate that tuffaceous sediments include substantial amounts of zeolitic alteration, which results in extensive cation exchange. Although $\mathrm{HCO}_{3}$ is the dominant anion, $\mathrm{SO}_{4}$ and lesser $\mathrm{Cl}$ are significant (approximately 30 percent of the anion total).

Specific conductance measured over a 32-year period spanning most of the water production (March 1971 to January 2003) ranges from 400 to $465 \mu \mathrm{S} / \mathrm{cm}$, with a median value of $450 \mu \mathrm{S} / \mathrm{cm}$ (fig. 16). Most measurements are within expected error limits ( \pm 5 percent) of the median value; however, values increase systematically over the period of record. Parametric and nonparametric tests indicate that the trend of increasing values is statistically significant at the 95-percent confidence limit (table 6; appendix D-5). These results are based on a relatively small number of unevenly distributed analyses (three analyses between 1971 and 1977, three analyses between 1988 and 1993, and six analyses between 1999 and 2003). Samples with the highest conductance values are from water sampled after most pumping ceased (post-1998); however, samples collected from intermediate timeframes (late 1980s to early 1990s) have intermediate conductance values despite being sampled during periods of high and low pumping. Although the observed trend is not compelling, these data allow for the possibility that water pumped from UE-5c WW became progressively more enriched in dissolved ions with time. If so, a similar increase in major-ion concentration might be expected.

Table 6. Results of trend analyses for major constituents in water pumped from UE-5c WW, Nevada National Security Site, Nye County, Nevada, between March 23, 1971, and January 28, 2003.

\begin{tabular}{|c|c|c|c|c|c|c|}
\hline Constituent & $\begin{array}{c}\text { Total } \\
\text { samples }\end{array}$ & $\begin{array}{l}\text { Normality } \\
\text { tests }\end{array}$ & $\begin{array}{c}\text { MK } \\
\text { result }\end{array}$ & $\begin{array}{c}\text { SES } \\
\text { result }\end{array}$ & $\begin{array}{c}\text { Residual } \\
\text { normality } \\
\text { test }\end{array}$ & $\begin{array}{l}\text { LR } \\
\text { result }\end{array}$ \\
\hline Conductivity & 12 & passed & increasing & increasing & passed & increasing \\
\hline Calcium (Ca) & 9 & passed & no trend & no trend & passed & no trend \\
\hline Magnesium (Mg) & 9 & failed & decreasing & decreasing & - & - \\
\hline Sodium (Na) & 8 & passed & no trend & no trend & failed & - \\
\hline Potassium (K) & 8 & passed & no trend & no trend & passed & no trend \\
\hline Chloride (Cl) & 9 & passed & no trend & no trend & passed & no trend \\
\hline Bicarbonate $\left(\mathrm{HCO}_{3}\right)$ & 9 & passed & no trend & no trend & passed & no trend \\
\hline Sulfate $\left(\mathrm{SO}_{4}\right)$ & 7 & passed & increasing & increasing & passed & increasing \\
\hline Silicon dioxide $\left(\mathrm{SiO}_{2}\right)$ & 7 & passed & no trend & no trend & passed & increasing \\
\hline Fluoride (F) & 8 & passed & no trend & no trend & passed & no trend \\
\hline
\end{tabular}


A.

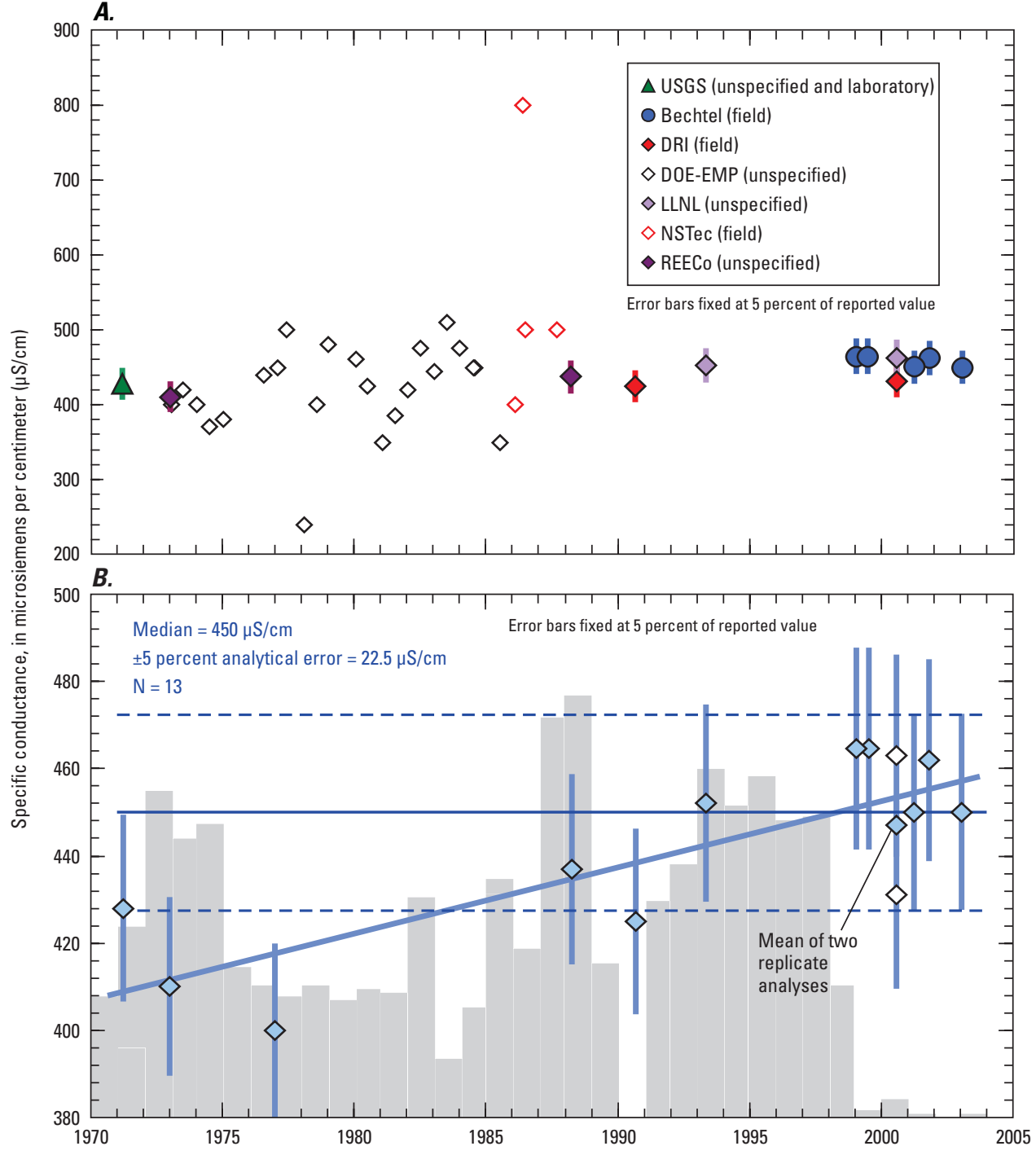

Figure 16. Temporal variations in specific conductance for water samples collected from UE-5c WW, Nevada National Security Site, Nye County, Nevada. (A) All available specific conductance data from appendix $A$, identified by source including Bechtel, Bechtel Nevada; DOE-EMP, Department of Energy Environmental Monitoring Program; DRI, Desert Research Institute; LLNL, Lawrence Livermore National Laboratory; NSTec, National Security Technologies, LLC; REECo, Reynolds Electrical \& Engineering Co., Inc.; and USGS, U.S. Geological Survey. Reported measurements were either made in the field, the laboratory, or were unspecified in the database. $(B)$ Specific conductance data used to calculate the median value and trend analysis are shown as filled diamonds. Open symbols represent multiple analyses for a single sampling event that were used to calculate the mean value for that event (shown as a filled diamond for the same date). Thick, horizontal blue line represents median value shown along with estimates for 5 percent measurement error (dashed blue lines). Thick sloping line represents a statistically significant trend (see results in appendix D). Shaded histogram represents annual groundwater withdrawals from UE-5c WW (see appendix E, fig. E-14 for withdrawal values). 
Major ion concentrations in water from UE-5c WW commonly show scatter beyond the expected analytical uncertainties associated with calculated median values (fig. 17). However, only $\mathrm{SO}_{4}, \mathrm{Mg}$, and $\mathrm{SiO}_{2}$ show statistically significant shifts with time (appendix D-5). Like conductance, $\mathrm{SO}_{4}$ and $\mathrm{SiO}_{2}$ concentrations show progressive increases. Concentrations of $\mathrm{Mg}$ gradually decrease with time; however, a commensurate decrease in Ca concentration is not observed. None of the major ion concentrations show an obvious shift associated with the large decrease in pumping from a relatively steady withdrawal rate of about 2 to $8 \mathrm{Mgal} / \mathrm{yr}$ between 1970 and 1997 to less than several hundred thousand gallons per year after 1998 (fig. 17). Therefore, the small chemical changes observed for only several constituents in UE-5c WW are difficult to attribute to pumping related processes. The quality and quantity of data available from UE-5c WW do not provide convincing evidence for shifts in composition with time. However, construction of the well provides two open intervals (appendix E, fig. E-13) that may have contributed different amounts of groundwater at different times. Although most water was likely derived from the perforated zone in the alluvial aquifer, small contributions from the lower tuff confining unit may have influenced the overall chemistry of water and caused small changes in some of the constituents.

Trace element concentrations reported for UE-5c WW groundwater are limited (appendix C). Older, semiquantitative results for $\mathrm{Fe}, \mathrm{Li}$, and $\mathrm{Mn}$, reported for samples from the early 1970s through the 1980s, are not accurate enough to allow good comparisons with more reliably determined data from the 1990s and 2000s. A single Sr concentration of $60 \mu \mathrm{g} / \mathrm{L}$ obtained in 1971 is the only Sr value reported for pre-1990s samples. This value is considered analytically unresolvable from values of 51 and $62 \mu \mathrm{g} / \mathrm{L}$ obtained from samples analyzed in 1993 and 2000, respectively. Arsenic (As) analyses have been reported since 1984. Unlike other available trace element concentrations, As concentrations progressively increased from 5 to $19.6 \mu \mathrm{g} / \mathrm{L}$ from 1984 to 2003 (fig. 18). This represents an approximate 300 percent increase during the 18-year period implying a rate of change in concentration of approximately $0.66 \pm 0.22 \mu \mathrm{g} / \mathrm{L} / \mathrm{yr}$. Major ions and other trace elements do not show similar large temporal trends. Therefore, conditions affecting As solubility, such as changes in redox potentials or adsorption-desorption capacities, may have occurred in the alluvial aquifer producing water in UE-5c WW, or in the immediate vicinity of the completed well (for instance, degradation of the casing, pump, or other introduced materials). Two analyses of dissolved oxygen reported from 1993 and 2000 are similar (5.5 and 5.1, respectively; Geochem08, revision 3.0; Stoller-Navarro Joint Venture, 2008), and do not indicate large changes in oxidation potential over the period when As increased from 12.4 to $19.6 \mu \mathrm{g} / \mathrm{L}$.

Analyses of $\delta^{2} \mathrm{H}$ and $\delta^{18} \mathrm{O}$ are available only for two samples collected in 1993 and 2000 (appendix C). Values of -105 to -106.5 for $\delta^{2} \mathrm{H}$ and -13.7 to -13.8 for $\delta^{18} \mathrm{O}$ are analytically identical and represent compositions that are intermediate within the range obtained from NNSS groundwater (fig. 19). Identical values for $\delta^{2} \mathrm{H}$ and $\delta^{18} \mathrm{O}$ during this 7-year period, which spans the period of activeto-sporadic pumping, implies that sources of water remained constant. However, strontium isotopic compositions $\left({ }^{87} \mathrm{Sr} /{ }^{86} \mathrm{Sr}\right.$ ) of 0.70975 and 0.70947 determined for these same two samples (appendix C) are similar but beyond analytical uncertainties ( \pm 0.00005$)$, indicating the possibility of small changes in the $\mathrm{Sr}$ isotopic composition during this period. Changes in aquifer or well conditions that caused the shift in As concentrations also could have affected ${ }^{87} \mathrm{Sr} /{ }^{86} \mathrm{Sr}$ compositions by selective dissolution of individual minerals or desorption of heterogeneous constituents within the aquifer rock, or by progressive degradation of materials introduced into the well. 

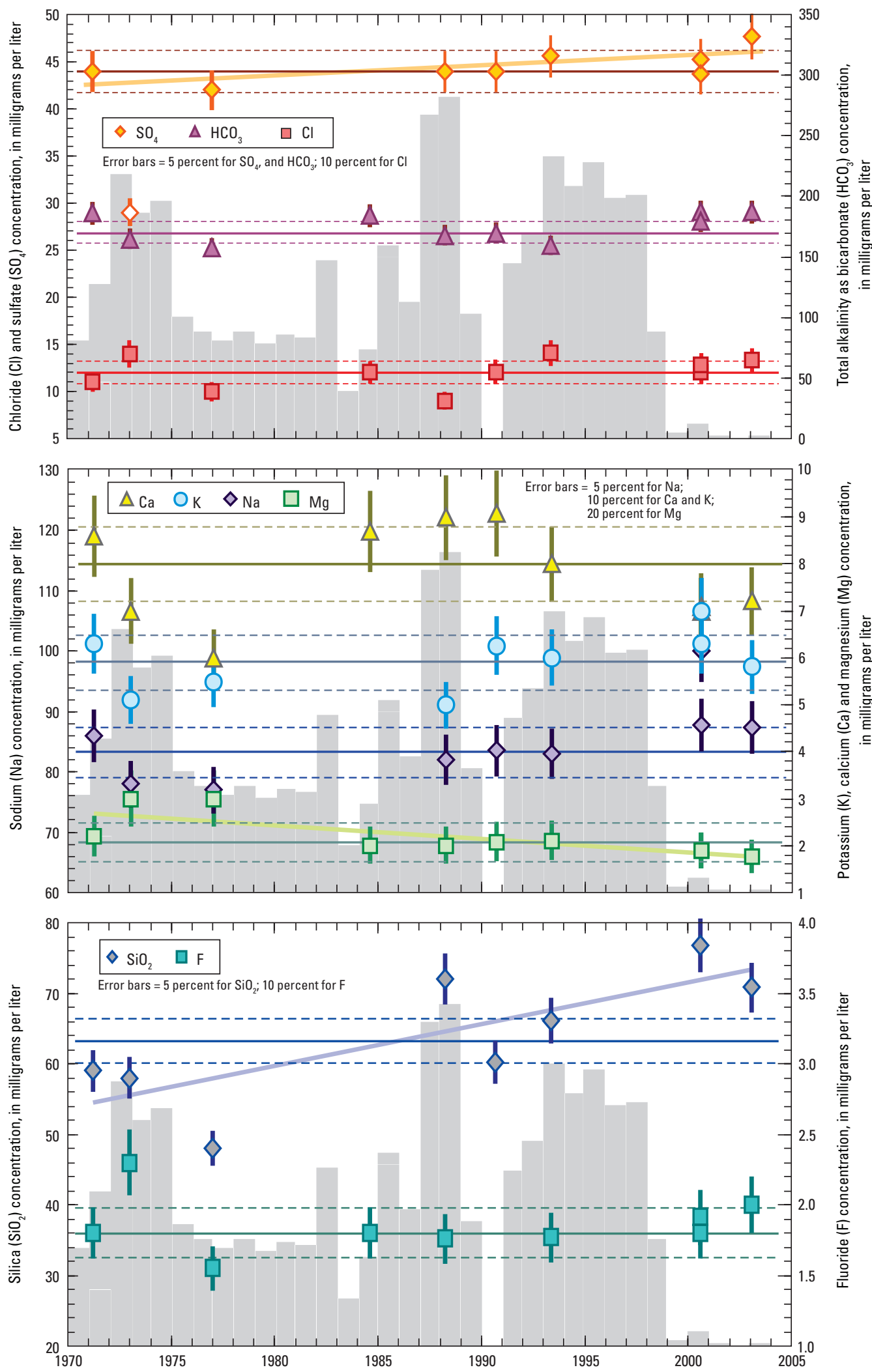

Figure 17. Temporal variations in major-ion concentrations for water samples collected from UE-5c WW, Nevada National Security Site, Nye County, Nevada. Filled symbols represent data from appendix B used to calculate trend analyses and quantitative statistics (see results in appendix D and appendix $\mathrm{F}$, respectively). Open symbols represent outliers and were not included in numerical evaluations. Solid horizontal lines represent median concentration values shown along with estimated measurement error (dashed horizontal lines) using the same values given for error bars on individual analyses. Thick sloping lines represent statistically significant trends. Shaded histogram represents annual groundwater withdrawals from UE-5c WW (see appendix E, fig. E-14 for withdrawal values). 


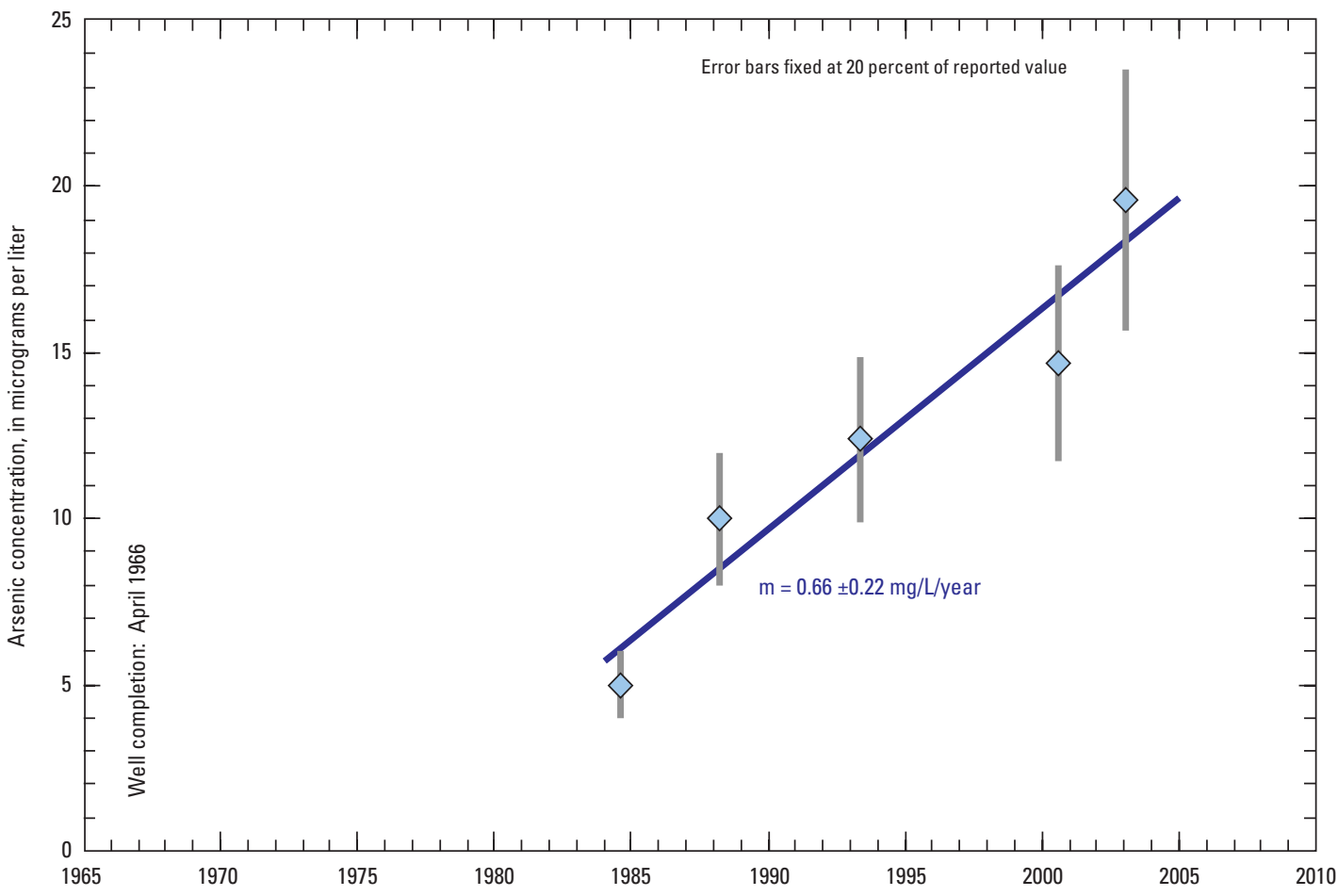

Figure 18. Temporal variations in arsenic concentration for water samples collected from UE-5c WW, Nevada National Security Site, Nye County, Nevada. Sloping line represents results of linear regression with a slope value $(\mathrm{m})$ of 0.66 milligrams per liter per year.

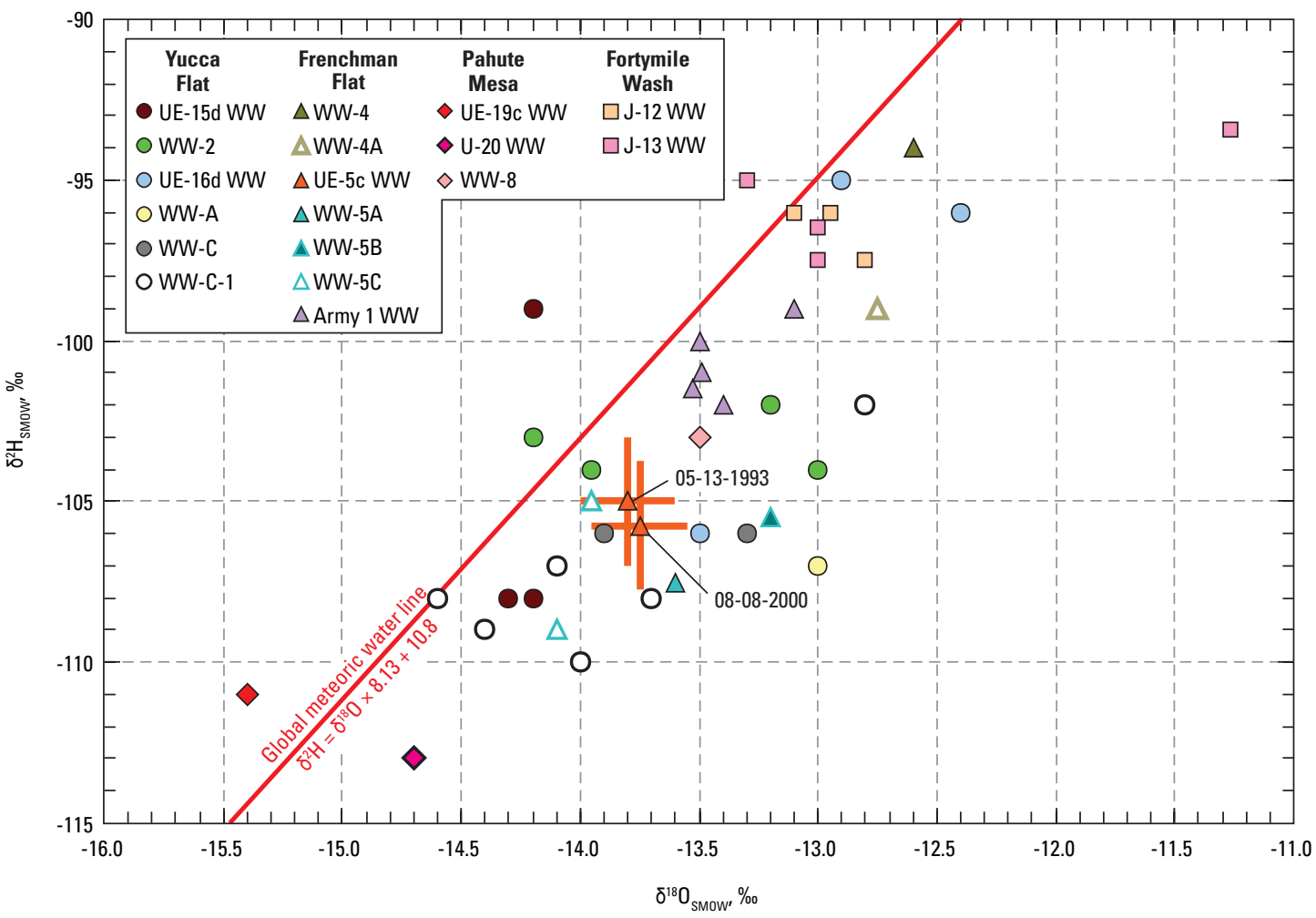

Figure 19. Isotopic compositions of hydrogen and oxygen for water samples collected from UE-5c WW and data from other water-supply wells at the Nevada National Security Site, Nye County, Nevada. 


\section{UE-15d WW}

Borehole Description and Water Withdrawals: UE-15d WW is at the north end of Yucca Flat in Area 15 of the NNSS (fig. 1; table 1). The borehole was drilled to a depth of 6,001 ft in March 1962 and completed as a supply well in April 1962. Borehole UE-15d WW had an initial completion, well $U E-15 d W W(1735-6001 \mathrm{ft}$ ), that consisted of casing to a depth of 1,735 ft with an open borehole from 1,735 to $6,001 \mathrm{ft}$. A second completion, finished in April 1962, well UE-15d WW (cased) involved hanging a liner in the open borehole from 1,667 to 5,400 ft, which is slotted from 2,800 to $5,400 \mathrm{ft}$. The annular space between the liner and borehole is open from $1,735 \mathrm{ft}$ to the bottom of the casing (appendix E, fig. E-16). The mean water level in the final completion, well $U E-15 d W W$ (cased), is at a depth of $680 \mathrm{ft}$ below land surface.

UE-15d WW penetrated alluvium from 0 to $290 \mathrm{ft}$, followed by alternating layers of welded and nonwelded tuffs from 290 to 1,773 ft, clastic sediments (mostly quartzite with lesser argillite and siltstone associated with the Precambrianaged Stirling Quartzite and Johnnie Formation) from 1,773 to $5,320 \mathrm{ft}$, and dolomite (likely Precambrian Noonday Dolomite) from 5,290 to 6,001 ft (appendix E, fig. E-16; Wood, 2007). Most of the water from the well is produced from the dolomite, which has been included in the lower carbonate aquifer, but probably represents a deeper aquifer that is isolated from the shallower Paleozoic carbonate units. Above the dolomite, the well intersects four permeable zones from 1,940 to $5,330 \mathrm{ft}$, with the highest permeability from 4,441 to 5,330 ft (R.F. Norvitch, U.S. Geological Survey, written commun., 1962, p. 9). This zone is dominated by quartzite and argillite and has been included in the lower clastic confining unit HSU.
UE-15d WW was originally drilled to obtain geologic and hydrologic data in northern Yucca Flat and was later used to supply water to an experimental farm in Area 15, maintained by the EPA from 1965 to 1981 (U.S. Department of Energy, 2004, 2005, p. 60). About $352 \mathrm{Mgal}$ of water were withdrawn from UE-15d WW (appendix E, fig. E-17). Pumping ceased in November 1981 when the farm closed and no known withdrawals have occurred since then.

Water Quality: Water from UE-15d WW has a range of compositions that include $\mathrm{HCO}_{3}$ water types that are Na-rich and Ca-rich. Anion compositions cluster tightly on a trilinear plot of major ions (appendix E, fig. E-18), with $\mathrm{HCO}_{3}$ constituting approximately 80 percent of the dissolved anion load. In contrast, cation compositions show a wide spread from 35 to 60 percent $\mathrm{Na}+\mathrm{K}$ and 25 to 55 percent $\mathrm{Ca}$. As a result, compositions from UE-15d WW plot over a range intermediate between those typical of volcanic and carbonate aquifers.

Specific conductance, measured over a 29 -year period from November 1961 to August 1990, ranges from 586 to $750 \mu \mathrm{S} / \mathrm{cm}$ with a median value of $698 \mu \mathrm{S} / \mathrm{cm}$ (fig. 20). Most individual values are within expected error limits ( \pm 5 percent) of the median value; however, values decreased systematically over the period of record. The Mann-Whitney and two-sample t-tests of data for pre-1975 samples (mean value $=718 \pm 14$ [ $\pm 2 \times$ standard error, or $2 \mathrm{SE}] \mu \mathrm{S} / \mathrm{cm} ; \mathrm{N}=7$ ) indicate a statistically significant difference from post-1975 samples, regardless of whether all values are included (mean $=645 \pm 36$ $[ \pm 2 \mathrm{SE}] \mu \mathrm{S} / \mathrm{cm}$ for $\mathrm{N}=6$ ) or if the last two values sampled in 1990 are excluded (mean $=670 \pm 12[ \pm 2 \mathrm{SE}] \mu \mathrm{S} / \mathrm{cm}$ for $\mathrm{N}=4$ ). Parametric and nonparametric tests of trend indicate a decrease in specific conductance values with time (table 7; appendix D-6). These data imply that water pumped from UE-15d WW may have become progressively more dilute as pumped volumes decreased in the late 1970s and ceased by 1981 . 


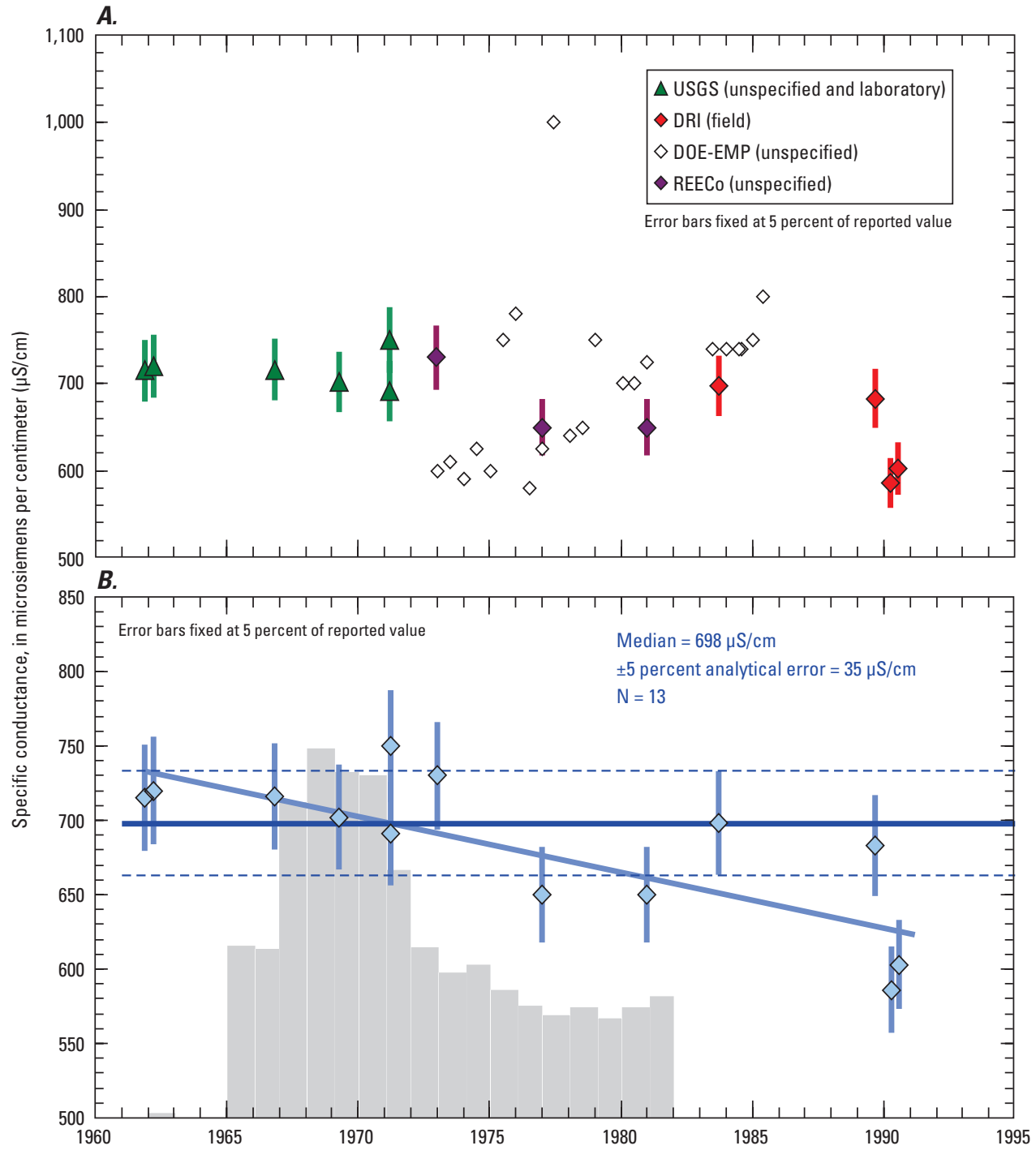

Figure 20. Temporal variations in specific conductance for water samples collected from UE-15d WW, Nevada National Security Site, Nye County, Nevada. (A) All available specific conductance data from appendix $A$, identified by source including DOE-EMP, Department of Energy Environmental Monitoring Program; DRI, Desert Research Institute; REECo, Reynolds Electrical \& Engineering Co., Inc.; and USGS, U.S. Geological Survey. Reported measurements were either made in the field, the laboratory, or were unspecified in the database. $(B)$ Specific conductance data used to calculate the median value and trend analysis. Thick, horizontal blue line represents median value shown along with estimates for 5 percent measurement error (dashed blue lines). Thick sloping line represents a statistically significant trend (see results in appendix D). Shaded histogram represents annual groundwater withdrawals from UE-15d WW (see appendix E, fig. E-17 for withdrawal values). 
Table 7. Results of trend analyses for major constituents in water pumped from UE-15d WW, Nevada National Security Site, Nye County, Nevada, between November 2, 1966, and August 1, 1990.

[A bbreviations: MK, Mann-Kendall test; SES, Sen's estimator of slope test; LR, linear regression; -, not applicable]

\begin{tabular}{lclcccc}
\hline \multicolumn{1}{c}{ Constituent } & $\begin{array}{c}\text { Total } \\
\text { samples }\end{array}$ & $\begin{array}{c}\text { Normality } \\
\text { tests }\end{array}$ & $\begin{array}{c}\text { MK } \\
\text { result }\end{array}$ & $\begin{array}{c}\text { SES } \\
\text { result }\end{array}$ & $\begin{array}{c}\text { Residual } \\
\text { normality } \\
\text { test }\end{array}$ & $\begin{array}{c}\text { LR } \\
\text { result }\end{array}$ \\
\hline Conductivity & 9 & passed & decreasing & decreasing & passed & decreasing \\
Calcium $(\mathrm{Ca})$ & 10 & passed & no trend & no trend & passed & no trend \\
Magnesium $(\mathrm{Mg})$ & 10 & failed & no trend & no trend & - & - \\
Sodium $(\mathrm{Na})$ & 9 & failed & decreasing & decreasing & - & - \\
Potassium $(\mathrm{K})$ & 9 & passed & no trend & no trend & passed & no trend \\
Chloride $(\mathrm{Cl})$ & 10 & failed & no trend & no trend & - & - \\
Bicarbonate $\left(\mathrm{HCO}_{3}\right)$ & 10 & inconclusive & decreasing & decreasing & passed & decreasing \\
Sulfate $\left(\mathrm{SO}_{4}\right)$ & 9 & passed & no trend & no trend & passed & no trend \\
Silicon dioxide $\left(\mathrm{SiO}_{2}\right)$ & 9 & passed & increasing & increasing & passed & increasing \\
Fluoride $(\mathrm{F})$ & 7 & passed & decreasing & decreasing & passed & no trend \\
\hline
\end{tabular}

Major ion concentrations of water sampled from UE-15d WW between November 1961 and August 1990 commonly show scatter beyond the expected analytical uncertainties for calculated median values (fig. 21). Several analytes $\left(\mathrm{SO}_{4}, \mathrm{Na}\right.$, $\mathrm{Ca}$, and to a lesser degree, $\mathrm{HCO}_{3}$ and $\mathrm{Mg}$ ) show anomalous values for two samples collected in 1961, prior to well completion, and in 1962. Concentrations commonly show erratic behavior, even if these two samples are excluded. This indicates that the well may not have been adequately purged of drilling fluids prior to the start of significant pumping in 1965. Concentrations of $\mathrm{HCO}_{3}$ and Na decreased monotonically with time, whereas $\mathrm{SiO}_{2}$ had an overall increase in concentration (table 7; appendix D-6). However, these trends are strongly influenced by anomalous values for two samples collected in 1990 nearly a decade after pumping ceased. If these two samples are excluded from the trend analysis, neither $\mathrm{HCO}_{3}$ nor $\mathrm{Na}$ data define significant temporal changes throughout or shortly after the main period of pumping. Concentrations of $\mathrm{Cl}$ appear to vary systematically with time, nearly doubling in samples collected in 1977 and 1981 (fig. 21); however, these two data points may be spurious as concentrations for samples collected from other wells during this same time commonly give anomalous results. This likelihood is supported by $\mathrm{Cl}$ concentrations reported from 1983 to 1990 that were similar to low values obtained from samples collected in the late 1960s. Collectively, these results do not show compelling evidence that water compositions from UE-15d WW varied systematically during and after the main period of water withdrawal. Nevertheless, concentrations of most major ions in UE-15d WW samples show greater scatter about median values compared to other supply wells indicating that aquifer or well conditions may have been somewhat unstable.

Trace element concentrations for samples from UE-15d WW are sparse (appendix C). Much of the reported data are considered unreliable ( $\mathrm{Fe}$ and $\mathrm{Mn}$ ) or were only determined semiquantitatively. Boron (B) and lithium (Li) concentrations were higher in samples reported from 1966 to 1971 (mean values of 160 and $170 \mu \mathrm{g} / \mathrm{L}$ for $\mathrm{B}$ and $\mathrm{Li}$, respectively) compared to samples reported from 1973 to 1981 (120 and $90 \mu \mathrm{g} / \mathrm{L}$, respectively); however, the reliability of these semiquantitative analyses are unknown. In contrast, the two analyses reported for $\mathrm{U}$ from samples collected in 1971 and 1989 remained identical at $2.7 \mu \mathrm{g} / \mathrm{L}$ (appendix C). Analyses of $\delta^{2} \mathrm{H}$ and $\delta^{18} \mathrm{O}$ were reported for three water samples collected in 1983, 1989, and 1990 (appendix C). All three samples have analytically identical values for $\delta^{18} \mathrm{O}$ of -14.2 to $14.3 \%$ o (fig. 22) and two of the three have identical $\delta^{2} \mathrm{H}$ values of $-108 \%$ o (the $\delta^{2} \mathrm{H}$ value of $-99 \%$ o for the 1983 sample plots well above the global meteoric water line in figure 22 and is interpreted as an analytical aberration). The isotopically "light" values for $\delta^{18} \mathrm{O}$ are near the lower end of the range obtained from NNSS groundwater, which are consistent with a deep aquifer recharged under cooler climate conditions or at higher latitudes. The uniform values of $\delta^{18} \mathrm{O}$ data indicate that water sampled from UE-15d WW in 1983 had the same source as water sampled in 1989 and 1990. 

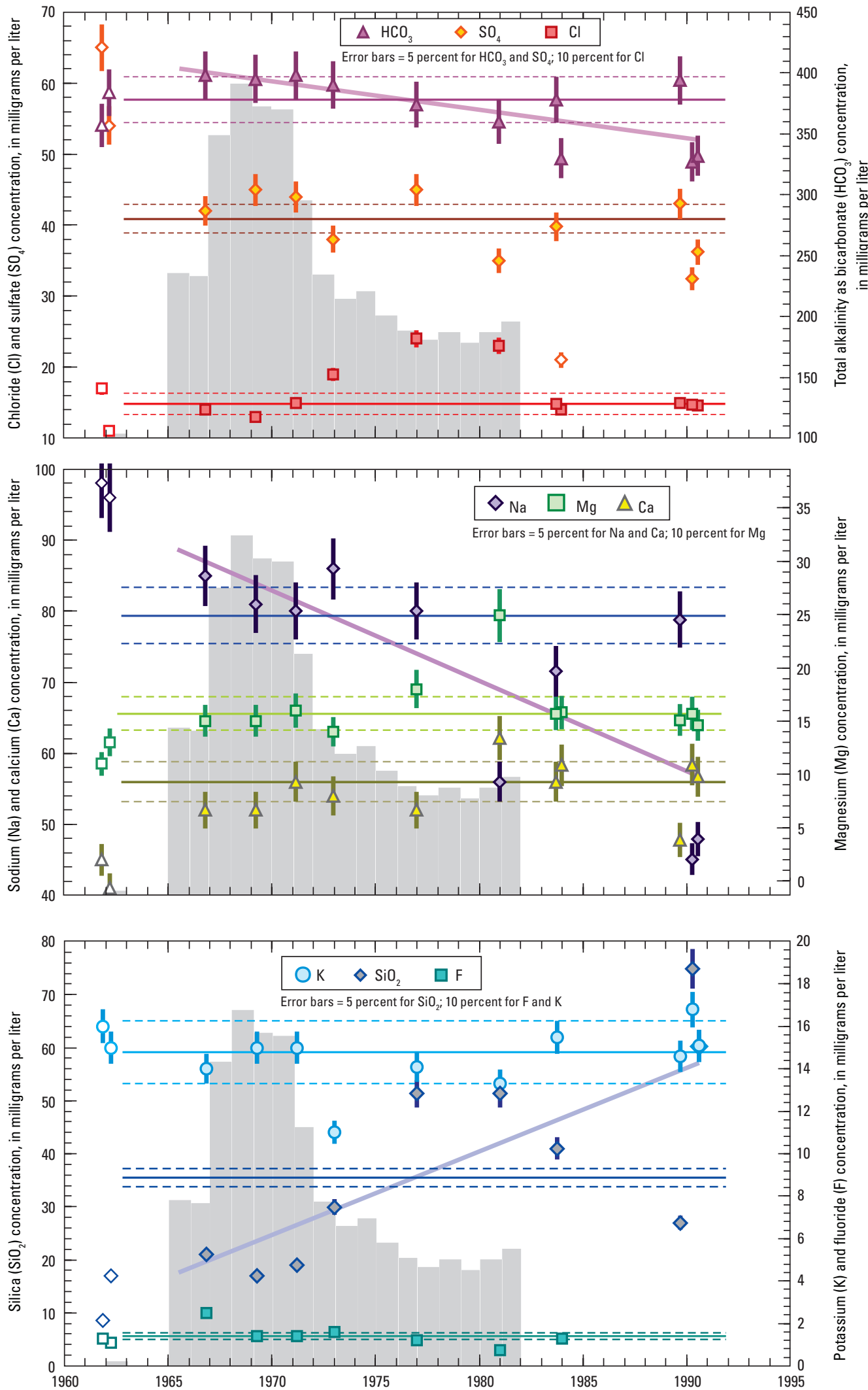

Figure 21. Temporal variations in major-ion concentrations for water samples collected from UE-15d WW, Nevada National Security Site, Nye County, Nevada. Filled symbols represent data from appendix B used to calculate trend analyses and quantitative statistics (see results in appendix $\mathrm{D}$ and appendix $\mathrm{F}$, respectively). Open symbols represent outliers and were not included in numerical evaluations. Solid horizontal lines represent median concentration values shown along with estimated measurement error (dashed horizontal lines) using the same values given for error bars on individual analyses. Thick sloping lines represent statistically significant trends. Shaded histogram represents annual groundwater withdrawals from UE-15d WW (see appendix E, fig. E-17 for withdrawal values). 


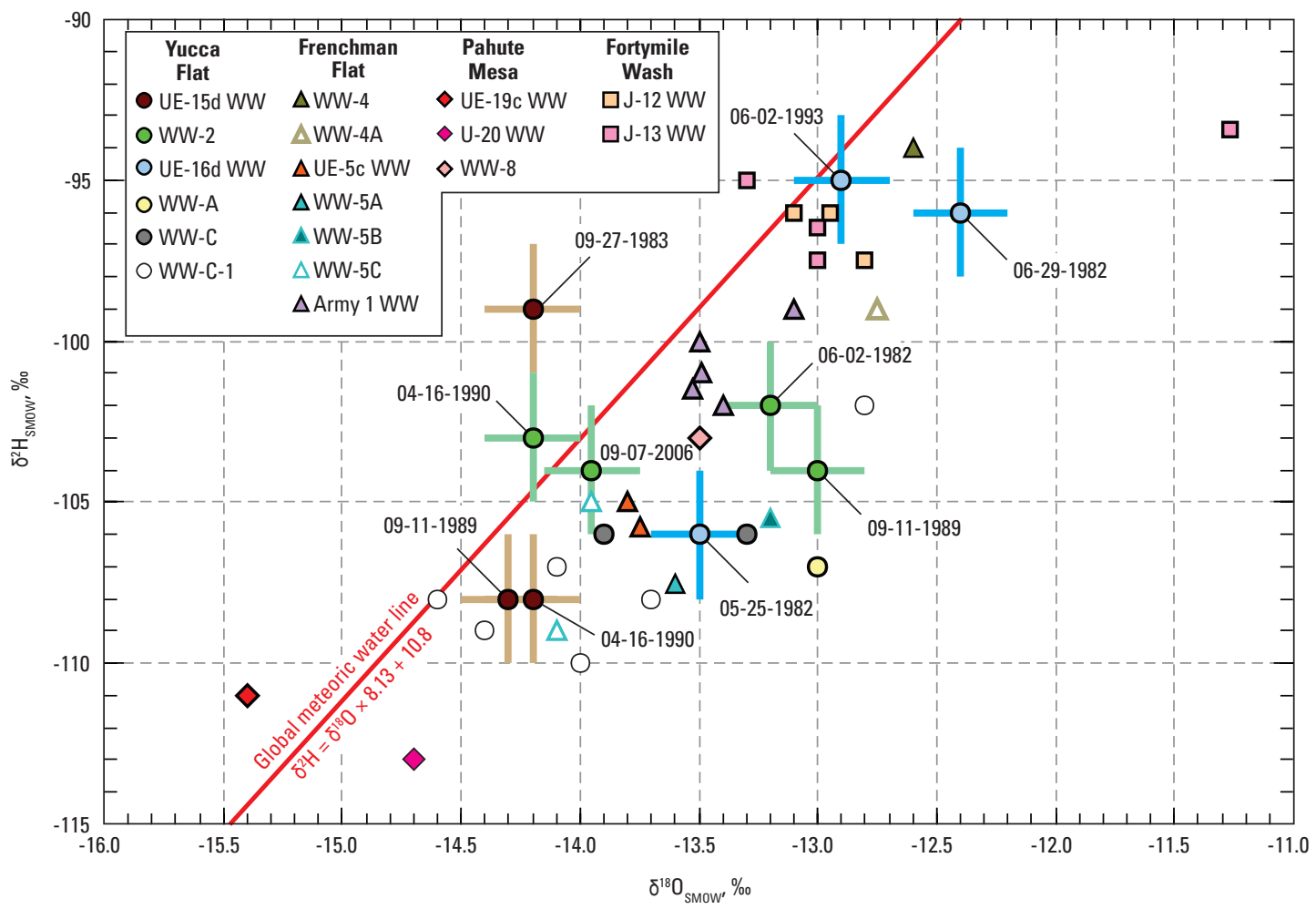

Figure 22. Isotopic compositions of hydrogen and oxygen for water samples from UE-15d WW, UE-16d WW, and WW-2 in Yucca Flat, and data from other water-supply wells at the Nevada National Security Site, Nye County, Nevada. 


\section{UE-16d WW}

Borehole Description and Water Withdrawals: UE-16d WW is west of Yucca Flat in Area 16 of the NNSS (fig. 1; table 1). The borehole was drilled to a depth of 3,000 ft in August 1977 and recompleted as a supply well in March 1981. The single completion in the borehole, well $U E-16 d W W$, is cased to a depth of 2,117 ft with perforations from 1,145 to $1,310 \mathrm{ft}$. The annular space between the casing and borehole is open from 81 to 1,944 ft (appendix E, fig. E-19). The uncased lower part of the borehole is sealed from the cased, upper part by a bridge plug. The mean water level in the well is at a depth of $753 \mathrm{ft}$ below land surface.

The borehole penetrates alluvium from 0 to $80 \mathrm{ft}$, followed by a structurally complex sequence of Pennsylvanian through early Permian limestone with interbedded siltstone, quartzite, and argillite (Tippipah Limestone) from 80 to 1,487 ft (appendix E, fig. E-19; Dinwiddie and Weir, 1979, p. 5; Wood, 2007). Argillite with interbedded quartzite, siltstone, and minor limestone (Eleana Formation) is present from 1,487 to 3,000 ft. Most water is produced from the carbonate rocks in the upper part of the borehole that constitute the upper carbonate aquifer (Gillespie and others, 1996, p. 27).

UE-16d WW was originally drilled to obtain geologic and hydrologic data in the area immediately west of Yucca Flat (Dinwiddie and Weir, 1979, p. 1), and later was used as a supply well. Since 1981, $787 \mathrm{Mgal}$ of water have been withdrawn from the well, with 96 percent of the production withdrawn from 1985 to 2007 (appendix E, fig. E-20).
Water Quality: Water from UE-16d WW is characterized as a Ca-Mg- $-\mathrm{HCO}_{3}$ water that is typical of carbonate aquifers. Cation compositions for most samples form a tight cluster on a trilinear plot of major ions, and are dominated by $\mathrm{Ca}$ with lesser and subequal amounts of $\mathrm{Na}$ and $\mathrm{Mg}$ (appendix $\mathrm{E}$, fig. E-21). Anions show a larger range of compositions that are dominated by $\mathrm{HCO}_{3}$ with lesser $\mathrm{SO}_{4}$ and only small amounts of Cl.

Specific conductance has been measured for a 28 -year period, spanning most of the period of groundwater withdrawals. Conductance ranges from 633 to $724 \mu \mathrm{S} / \mathrm{cm}$ with a median value of $665 \mu \mathrm{S} / \mathrm{cm}$ (fig. 23). Most measurements are within expected error limits ( \pm 5 percent) of the median value. Parametric and nonparametric trend tests indicate that no systematic changes in conductance occurred during the main period of pumping (table 8; appendix D-7), despite the appearance that more recent measurements (2000s) yielded lower values than those reported for earlier (1980s and 1990s) samples. A two-sample t-test indicates that mean values calculated for early (1981-1993) and late (1999-2005) groupings are statistically distinguishable at the 95-percent confidence level $(687.5 \pm 14.4$ [2SE], versus $661.8 \pm 12.0$ [2SE], respectively). A nonparametric Mann-Whitney test also indicates that this difference is significant. These results imply that the water pumped from UE-16d WW has become progressively more dilute with time; however, the difference in composition is not large or compelling.

Table 8. Results of trend analyses for major constituents in water pumped from UE-16d WW, Nevada National Security Site, Nye County, Nevada, between January 1, 1981, and July 12, 2005.

[A bbreviations: MK, Mann-Kendall test; SES, Sen's estimator of slope test; LR, linear regression; -, not applicable]

\begin{tabular}{lclllcc}
\hline \multicolumn{1}{c}{ Constituent } & $\begin{array}{c}\text { Total } \\
\text { samples }\end{array}$ & $\begin{array}{c}\text { Normality } \\
\text { tests }\end{array}$ & $\begin{array}{c}\text { MK } \\
\text { result }\end{array}$ & $\begin{array}{c}\text { SES } \\
\text { result }\end{array}$ & $\begin{array}{c}\text { Residual } \\
\text { normality } \\
\text { test }\end{array}$ & $\begin{array}{c}\text { LR } \\
\text { result }\end{array}$ \\
\hline Conductivity & 20 & passed & no trend & no trend & passed & no trend \\
Calcium $(\mathrm{Ca})$ & 15 & passed & no trend & no trend & passed & no trend \\
Magnesium $(\mathrm{Mg})$ & 15 & passed & no trend & no trend & passed & no trend \\
Sodium $(\mathrm{Na})$ & 14 & failed & decreasing & decreasing & - & - \\
Potassium $(\mathrm{K})$ & 13 & inconclusive & no trend & no trend & failed & - \\
Chloride $(\mathrm{Cl})$ & 15 & passed & increasing & increasing & passed & increasing \\
Bicarbonate $\left(\mathrm{HCO}_{3}\right)$ & 12 & passed & decreasing & decreasing & failed & - \\
Sulfate $\left(\mathrm{SO}_{4}\right)$ & 14 & passed & no trend & no trend & passed & no trend \\
Silicon dioxide $\left(\mathrm{SiO}_{2}\right)$ & 14 & failed & decreasing & decreasing & - & - \\
Fluoride $(\mathrm{F})$ & 12 & passed & decreasing & decreasing & passed & decreasing \\
\hline
\end{tabular}




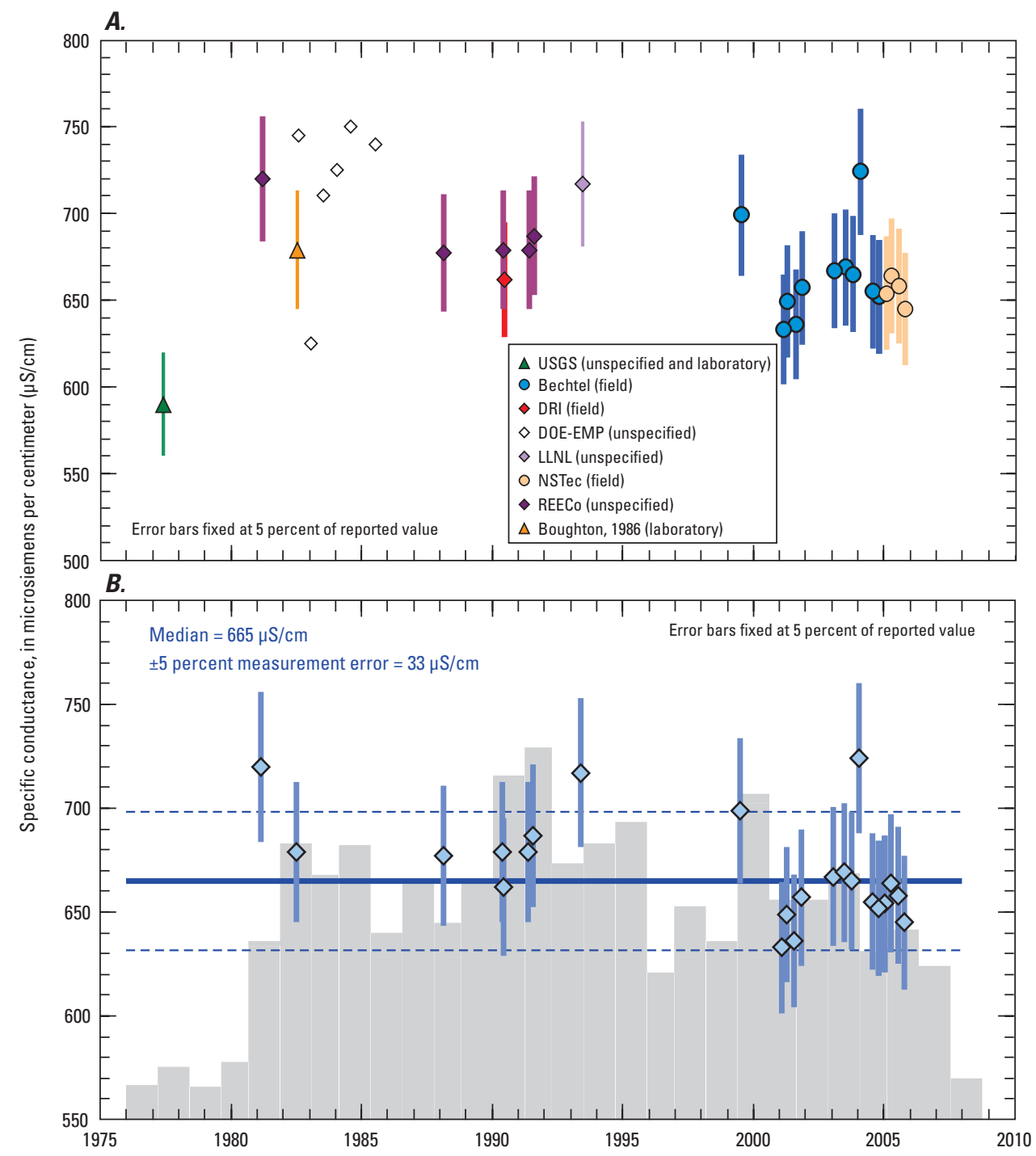

Figure 23. Temporal variations in specific conductance for water samples collected from UE-16d WW, Nevada National Security Site, Nye County, Nevada. (A) All available specific conductance data from appendix $A$, identified by source including Bechtel, Bechtel Nevada; Boughton, 1986; DOE-EMP, Department of Energy Environmental Monitoring Program; DRI, Desert Research Institute; LLNL, Lawrence Livermore National Laboratory; NSTec, National Security Technologies, LLC; REECo, Reynolds Electrical \& Engineering Co., Inc.; and USGS, U.S. Geological Survey. Reported measurements were either made in the field, the laboratory, or were unspecified in the database. $(B)$ Specific conductance data used to calculate the median value and trend analysis. Thick, horizontal blue line represents median value shown along with estimates for 5 percent measurement error (dashed blue lines). Shaded histogram represents annual groundwater withdrawals from UE-16d WW (see appendix E, fig. E-20 for withdrawal values). 
Major ion concentrations for water sampled from UE-16d WW from 1981 to July 2005 are commonly within the expected analytical uncertainties associated with their calculated median values (fig. 24). Samples collected in 1977 (appendix B), prior to recompletion of the well in 1981, show large deviations in concentration and are not considered representative of water in the same aquifer. For samples collected after 1977, results of parametric and nonparametric trend tests indicate that $\mathrm{HCO}_{3}, \mathrm{Na}, \mathrm{SiO}_{2}$, and $\mathrm{F}$ show small, but statistically significant decreases with time, whereas $\mathrm{Cl}$ shows an increase (table 8; appendix D-7). The small decreases in major ions with time are consistent with the small decreases in specific conductance noted previously. Other constituents, including $\mathrm{Ca}$ and $\mathrm{Mg}$, the dominant cations in UE-16d WW water, as well as $\mathrm{K}$ and $\mathrm{SO}_{4}$, remained constant during this same period.

Trace element concentration data for water sampled from UE-16d WW generally are unreliable (Fe and $\mathrm{Mn}$ ) or were only determined semiquantitatively (As, $\mathrm{Cd}, \mathrm{Cr}, \mathrm{Li}, \mathrm{Pb}$, Se, Zn; appendix C). Concentrations of B and Ba in samples from 1984 to 1988 generally are similar to values reported for samples from 1991 to 1993 . Analyses of $\delta^{2} \mathrm{H}$ and $\delta^{18} \mathrm{O}$ are available for two samples collected in May and June 1982, and one sample collected in June 1993 (appendix C). The June 1982 and June 1993 samples have analytically identical $\delta^{2} \mathrm{H}$ values of -95 and $-96 \%$ and similar $\delta^{18} \mathrm{O}$ values of -12.4 and $-12.9 \%$, which represent some of the isotopically "heaviest" values reported from NNSS supply wells (fig. 22).
In contrast, the May 1982 sample collected 1 month before the June 1982 sample, had substantially "lighter” (more negative) $\mathrm{H}$ and $\mathrm{O}$ isotopic compositions (106\% for $\delta^{2} \mathrm{H}$ and 13.5\%o for $\delta^{18} \mathrm{O}$ ). Isotope analyses reported for water sampled in 1977 lack $\delta^{2} \mathrm{H}$ determinations, but have $\delta^{18} \mathrm{O}$ values of $-12.6 \%$, which are intermediate between the isotopically "heavier" values reported in 1982 and 1993. Even though samples collected between 1977 and 1993 may reflect different well conditions, similar $\delta^{18} \mathrm{O}$ values between $12.4 \%$ and $12.9 \%$ for most samples is viewed as evidence that the single $\delta^{2} \mathrm{H}-\delta^{18} \mathrm{O}$ analysis from May 25, 1982, likely represents an aberration and does not indicate a major shift in water pumped from UE-16d WW.

Strontium isotopic compositions are reported from two samples collected in December 1989 and June 1993. The resulting ${ }^{87} \mathrm{Sr} /{ }^{86} \mathrm{Sr}$ values are analytically distinct (0.70994 and 0.71011), given the assumed individual analytical uncertainties $( \pm 0.00005)$, implying that they represent groundwater from separate sources. However, the net difference is small (0.00017) and still may be attributable to interlaboratory biases (USGS compared with Lawrence Livermore National Laboratory) that are beyond the range of internal analytical uncertainties. Unfortunately, the two sample dates are not sufficiently separated in time to evaluate whether the small shift in ${ }^{87} \mathrm{Sr} /{ }^{86} \mathrm{Sr}$ compositions between 1989 and 1993 is commensurate with the compositional shifts present for specific conductance and major ion data for UE-16d WW. 

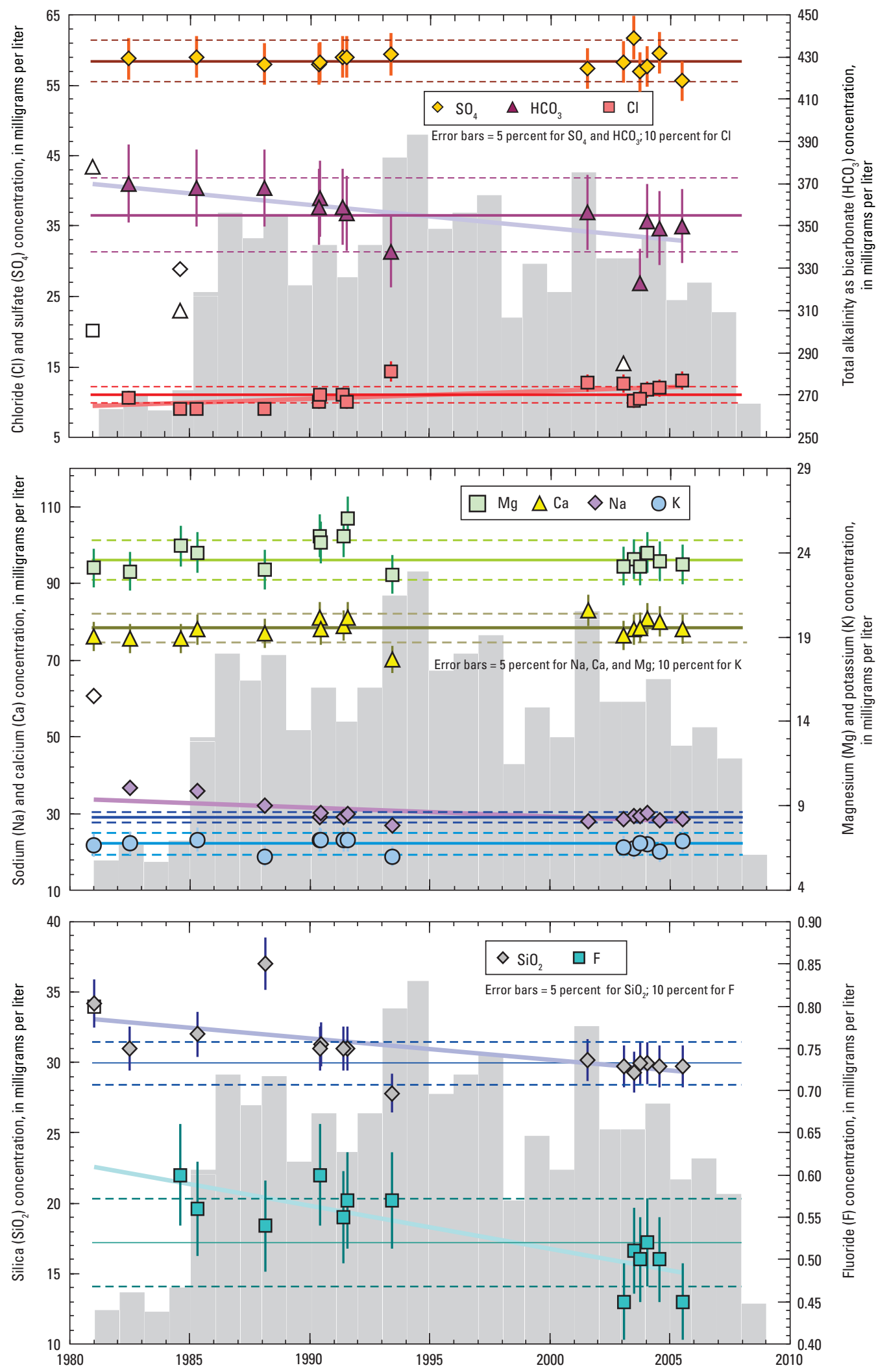

Figure 24. Temporal variations in major-ion concentrations for water samples collected from UE-16d WW, Nevada National Security Site, Nye County, Nevada. Filled symbols represent data from appendix B used to calculate trend analyses and quantitative statistics (see results in appendix D and appendix $\mathrm{F}$, respectively). Open symbols represent outliers and were not included in numerical evaluations. Solid horizontal lines represent median concentration values shown along with estimated measurement error (dashed horizontal lines) using the same values given for error bars on individual analyses. Thick sloping lines represent statistically significant trends. Shaded histogram represents annual groundwater withdrawals from UE-16d WW (see appendix E, fig. E-20 for withdrawal values). 


\section{UE-19c WW}

Borehole Description and Water Withdrawals: UE-19c WW is on Pahute Mesa in Area 19 of the NNSS (fig. 1; table 1). The borehole was drilled to a depth of 8,489 ft in June 1964. The single completion in the borehole, well $U E-19 c W W$, is cased to a depth of 2,421 ft and open from 2,422 to 8,489 ft (appendix E, fig. E-22). A 5.5-in. pump column was installed at a depth of 2,569 ft, and has a screened intake at 2,528 ft (Elliott and Moreo, 2011). The mean water level in the well is at a depth of 2,340 ft below land surface.

The borehole penetrates a thick sequence of interbedded welded and nonwelded tuffs, basalt and felsic lava flows, and flow breccias (appendix E, fig. E-22; Warren and others, 2003). Lithologies above about $2,400 \mathrm{ft}$ are dominated by welded and nonwelded tuffs associated with the Timber Mountain Tuff, Paintbrush Tuff, Calico Hills Formation, and Crater Flat Group. Lithologies below about 2,400 ft are dominated by lava flows associated with older volcanic eruptions in the area. Water pumped from the well likely originates from two zones based on changes in temperature gradients determined from geophysical logs (Blankennagel, 1968, p. 27). The upper zone, responsible for most of the water production, extends from 3,070 to 3,090 ft below land surface within a felsic lava flow. The lower zone, responsible for only a minor amount of the total water production, extends from 3,090 to 3,160 ft within a nonwelded tuff. Both zones are included within the pre-Belted Range composite unit HSU.

UE-19c WW was drilled to obtain geologic and hydrologic data in central Pahute Mesa and later was used as a supply well for Area 19. The well pumped continuously from July 1975 to October 1992, and sporadically through September 1994 (Elliott and Moreo, 2011). Based on available data, it is estimated that about 1,050 Mgal of water were withdrawn from the well from 1975 to 1994 (appendix E, fig. E-23), with peak withdrawals occurring from 1989 to 1991. No known withdrawals occurred after 1994.

Water Quality: Water from UE-19c WW is characterized as a $\mathrm{Na}_{-} \mathrm{HCO}_{3}$ water reflecting a source from zeolite-rich volcanic aquifers at Pahute Mesa. Sample cation concentrations form a tight cluster on a trilinear plot of major ions (appendix E, fig. E-24) and are dominated by $\mathrm{Na}$ with very low contributions from $\mathrm{Ca}$ and $\mathrm{Mg}$. Bicarbonate constitutes 80 to 90 percent of the anion content with small, subequal amounts of $\mathrm{SO}_{4}$ and $\mathrm{Cl}$.
Specific conductance measured in 1964 and 1966, before and shortly after well completion, respectively, shows a rapid decline from 1,235 to $644 \mu \mathrm{S} / \mathrm{cm}$. Both of these initial values are much larger than those measured after the borehole was recompleted in June 1975 (fig. 25A) and likely reflect the presence of drilling fluids that were not adequately purged until large amounts of pumping occurred. Numerous specific conductance measurements made from 1975 to 1985 for the Environmental Monitoring Program are considered unreliable because of the large amount of scatter in the data. Only four specific conductance measurements made in 1990 and 1992 are considered reliable. The median value for these four measurements is $154.5 \mu \mathrm{S} / \mathrm{cm}$ (fig. 25B).

Like specific conductance, analyses of major ion concentrations for UE-19c WW are only available for samples collected in 1964 and 1966, during and shortly after borehole construction, respectively, and in 1990 and 1992, late in the history of pumping (appendix B). The three reported analyses of water samples collected prior to well recompletion in 1975, have major element compositions that deviate substantially from concentrations analyzed in the 1990s, especially those collected in 1966 (fig. 26). Samples collected from 1990 to 1992 have major ion concentrations that are much more dilute than water samples from other NNSS supply wells. Concentrations of most analytes are within expected analytical uncertainties of median values calculated for the four separate samples (recognizing that larger uncertainties are assumed for low concentrations). The limited number and time span of samples collected for geochemical analysis is not sufficient to allow evaluation of trends.

Trace element concentrations reported for UE-19c WW are very limited (appendix C). Semiquantitative analyses of $\mathrm{Fe}, \mathrm{Li}$, and $\mathrm{Mn}$ have been reported for a few samples collected since 1964; however, concentrations are extremely variable, and characterization of compositional trends with time is not possible. Stable $\mathrm{H}$ and $\mathrm{O}$ isotope analyses are available for a single sample collected in April 1990 (appendix C). Results are similar to the isotopic compositions measured in U-20 WW with very "light" values of $-111 \%$ o for $\delta^{2} \mathrm{H}$ and $-15.4 \%$ for $\delta^{18} \mathrm{O}$ (fig. 14). Like the U-20 WW result, the isotopically "light" composition of water from UE-19c WW is consistent with recharge derived from sources at high latitudes and (or) under cold recharge conditions. 


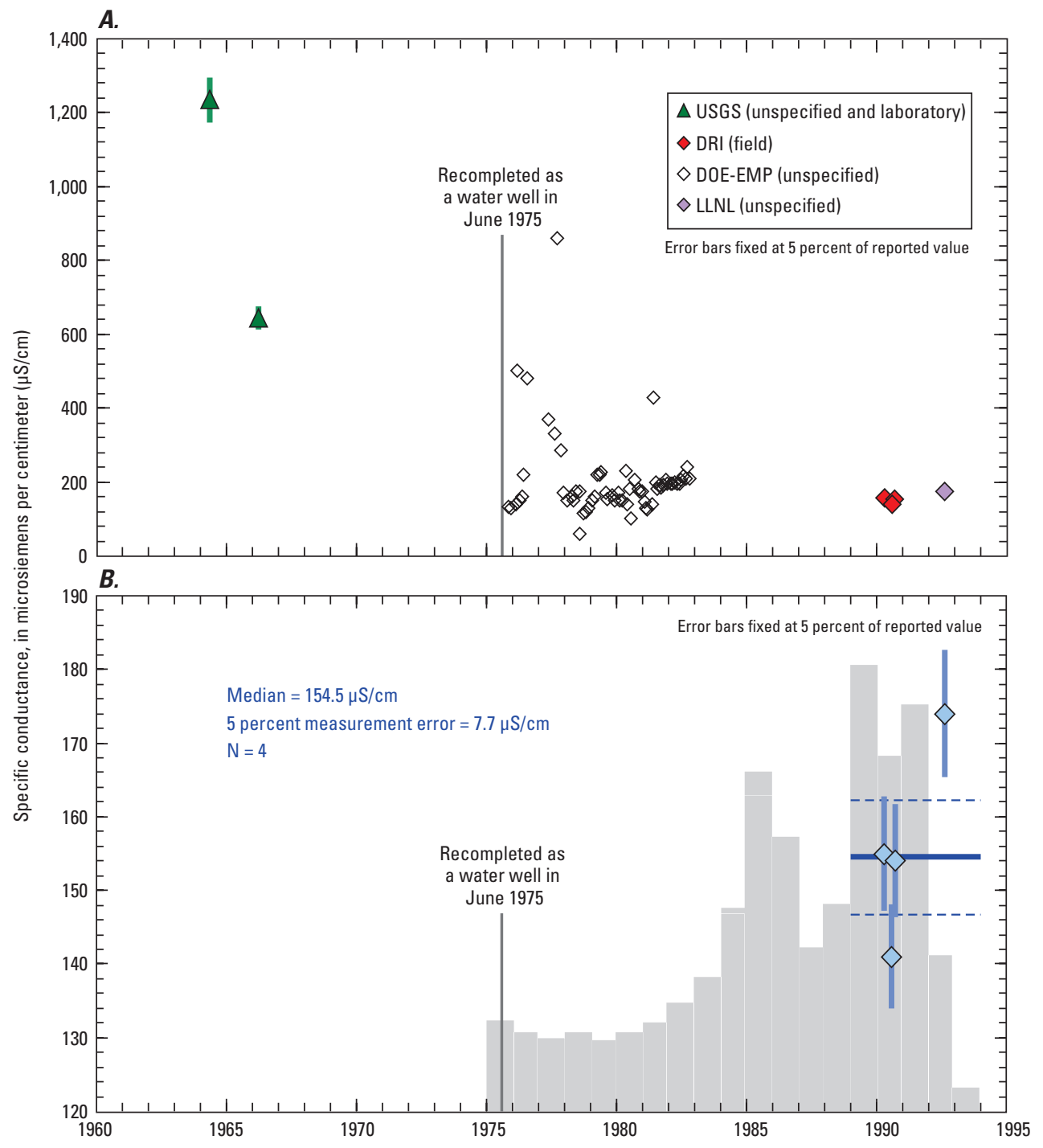

Figure 25. Temporal variations in specific conductance for water samples collected from UE-19c WW, Nevada National Security Site, Nye County, Nevada. (A) All available specific conductance data from appendix $A$, identified by source including DOE-EMP, Department of Energy Environmental Monitoring Program; DRI, Desert Research Institute; LLNL, Lawrence Livermore National Laboratory; and USGS, U.S. Geological Survey. Reported measurements were either made in the field, the laboratory, or were unspecified in the database. (B) Specific conductance data used to calculate the median value and trend analysis. Thick, horizontal blue line represents median value for samples collected from April 1990 to August 1992 shown along with estimates for 5 percent measurement error (dashed blue lines). Shaded histogram represents annual groundwater withdrawals from UE-19c WW (see appendix E, fig. E-23 for withdrawal values). 

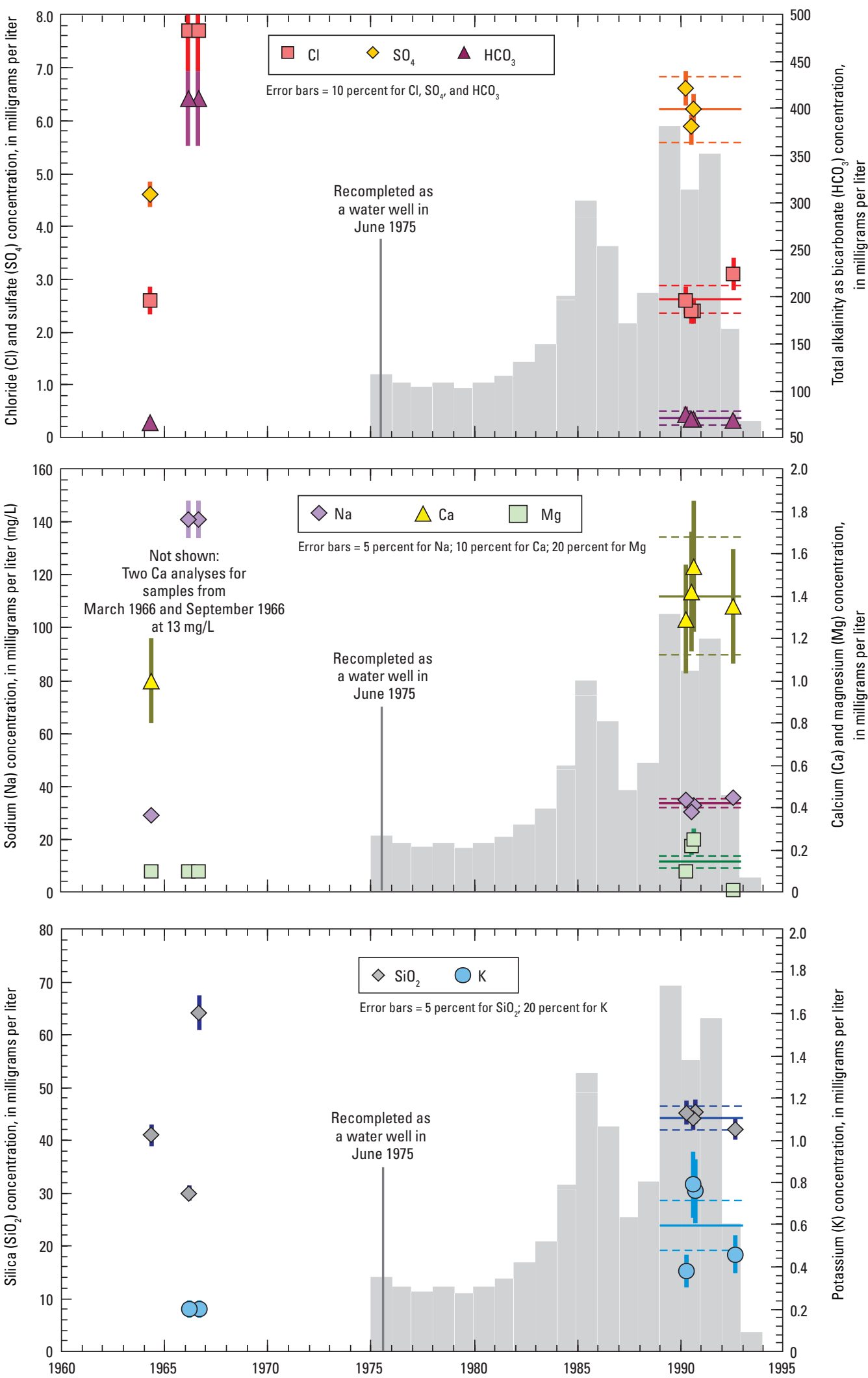

Figure 26. Temporal variations in major-ion concentrations for water samples collected from UE-19c WW, Nevada National Security Site, Nye County, Nevada. Filled symbols represent data from appendix B used to calculate trend analyses and quantitative statistics (see results in appendix D and appendix F, respectively). Solid horizontal lines represent median concentration values for samples collected from April 1990 to August 1992 shown along with estimated measurement error (dashed horizontal lines) using the same values given for error bars on individual analyses. Shaded histogram represents annual groundwater withdrawals from UE-19c WW (see appendix E, fig. E-23 for withdrawal values). 


\section{WW-2}

Borehole Description and Water Withdrawals: WW-2 is in northern Yucca Flat in Area 2 of the NNSS (fig. 1; table 1). The borehole was drilled to a total depth of 3,422 ft in March 1962. The single completion in the borehole, well $W W$-2 (3422 ft), is cased to its total depth, with two perforated zones from 2,700 to 2,950 ft and 3,164 to 3,412 ft (appendix E, fig. E-25). The annular space between the casing and borehole is open to the formations from 2,940 to 3,034 ft and 3,176 to 3,422 ft. The mean water level in the well is at a depth of 2,053 ft below land surface.

The borehole penetrated alluvium from 0 to $1,250 \mathrm{ft}$ (appendix E, fig. E-25); nonwelded tuff from 1,250 to 2,560 ft; and Ordovician-aged dolomite (Pogonip Group) below 2,560 ft, which includes interbedded limestone, shale, and argillite from 2,974 to 3,157 ft (Wood, 2007). The well produces most water from fractured carbonate rocks present in the lower of the two perforated zones from about 3,095 to 3,422 ft (Moore and others, 1963, p, 29). These units are part of the lower carbonate aquifer HSU. However, possible leakage of water from nonwelded tuffs constituting the overlying tuff confining unit was noted (U.S. Department of Energy, 1996a, p. 2-13).

WW-2 was originally constructed to acquire hydrologic data for evaluating groundwater movement beneath Yucca Flat (Moore and others, 1963, p. 3). Later, the well was used as a source of water for activities in Area 2 (U.S. Department of Energy, 1996a, p. 11). More than 1,030 Mgal of water were pumped from the well between 1962 and 1990 (appendix E, fig. E-26). Water-quality samples collected from 2001 to 2005 were obtained by bailer from discrete (but unknown) depths. In 2006, the pump was replaced, and approximately $0.035 \mathrm{Mgal}$ of water were pumped to purge the well and provide water-quality samples.

Water Quality: Water from WW-2 has a range of major ion compositions that appear to be derived from a mixture of carbonate and volcanic rocks. On a trilinear plot of major ions (appendix E, fig. E-27), cations occupy a broad area with roughly subequal proportions of $\mathrm{Na}, \mathrm{Ca}$, and $\mathrm{Mg}$ components. Anions are dominated by $\mathrm{HCO}_{3}$ with only small amounts of $\mathrm{SO}_{4}$ and $\mathrm{Cl}$. Compositions differ by sample collection dates. Samples collected during the main period of pumping (1962-1991) cluster together, with higher proportions of $\mathrm{Ca}+\mathrm{Mg}$ and $\mathrm{SO}_{4}$. Samples collected from 2001 to 2005 have distinctly higher proportions of $\mathrm{Na}+\mathrm{K}$ and $\mathrm{Cl}$. Finally, the single sample collected in 2006 has a major ion composition that is within the range defined by 1962-1991 samples.

Specific conductance for water sampled over the 29-year period of pumping (April 1962 to December 1990) ranges from 340 to $413 \mu \mathrm{S} / \mathrm{cm}$, with a median value of $389 \mu \mathrm{S} / \mathrm{cm}$ (fig. 27). Although most of these measurements overlap the limits expected for analytical error about the median value, individual values show a well-defined increase through 1991. Parametric and nonparametric tests confirm a statistically significant increasing trend from 1962 to 1991 (table 9; appendix D-8). These data indicate that dissolved ion concentrations in water pumped from WW-2 became progressively more concentrated as more water was withdrawn.

Table 9. Results of trend analyses for major constituents in water pumped from WW-2, Nevada National Security Site, Nye County, Nevada, between April 25, 1962, and January 30, 1991.

[A bbreviations: MK, Mann-Kendall test; SES, Sen's estimator of slope test; LR, linear regression; -, not applicable]

\begin{tabular}{lcccccc}
\hline \multicolumn{1}{c}{ Constituent } & $\begin{array}{c}\text { Total } \\
\text { samples }\end{array}$ & $\begin{array}{c}\text { Normality } \\
\text { tests }\end{array}$ & $\begin{array}{c}\text { MK } \\
\text { result }\end{array}$ & $\begin{array}{c}\text { SES } \\
\text { result }\end{array}$ & $\begin{array}{c}\text { Residual } \\
\text { normality } \\
\text { test }\end{array}$ & $\begin{array}{c}\text { LR } \\
\text { result }\end{array}$ \\
\hline Conductivity & 9 & passed & increasing & increasing & failed & - \\
Calcium $(\mathrm{Ca})$ & 11 & passed & increasing & increasing & failed & - \\
Magnesium $(\mathrm{Mg})$ & 11 & passed & increasing & increasing & passed & increasing \\
Sodium $(\mathrm{Na})$ & 10 & passed & increasing & increasing & passed & increasing \\
Potassium $(\mathrm{K})$ & 10 & passed & increasing & increasing & passed & no trend \\
Chloride $(\mathrm{Cl})$ & 11 & passed & no trend & no trend & passed & no trend \\
Bicarbonate $\left(\mathrm{HCO}_{3}\right)$ & 11 & passed & increasing & increasing & passed & increasing \\
Sulfate $\left(\mathrm{SO}_{4}\right)$ & 11 & passed & increasing & increasing & passed & increasing \\
Silicon dioxide $\left(\mathrm{SiO}_{2}\right)$ & 10 & failed & no trend & no trend & - & - \\
Fluoride $(\mathrm{F})$ & 5 & failed & no trend & no trend & - & - \\
\hline
\end{tabular}


A.

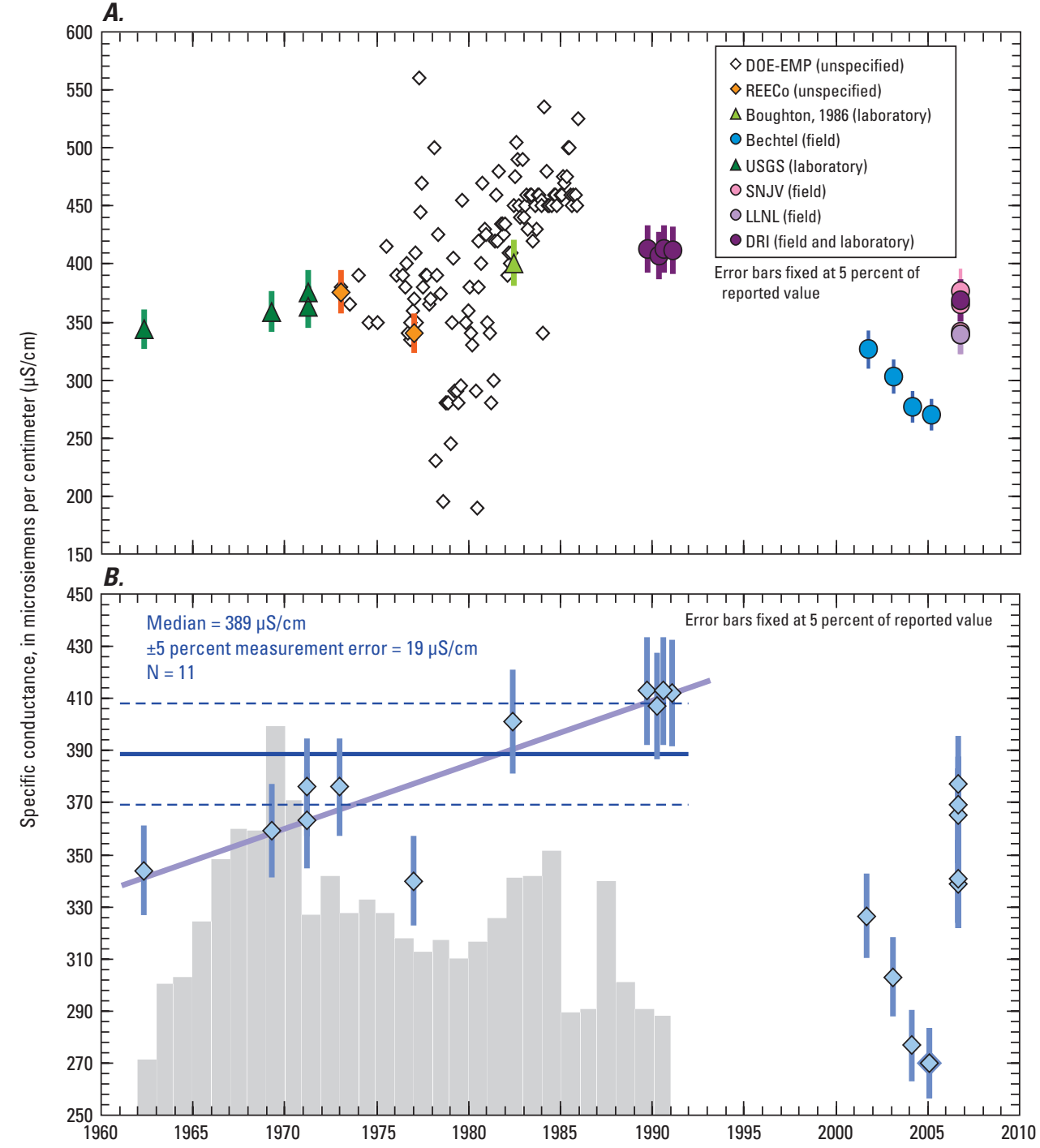

Figure 27. Temporal variations in specific conductance for water samples collected from WW-2, Nevada National Security Site, Nye County, Nevada. (A) All available specific conductance data from appendix A, identified by source including Bechtel, Bechtel Nevada; Boughton, 1986; DOE-EMP, Department of Energy Environmental Monitoring Program; DRI, Desert Research Institute; LLNL, Lawrence Livermore National Laboratory; REECo, Reynolds Electrical \& Engineering Co., Inc.; SNJV, Stoller-Navarro Joint Venture; and USGS, U.S. Geological Survey. Reported measurements were either made in the field, the laboratory, or were unspecified in the database. $(B)$ Specific conductance data used to calculate the median value and trend analysis for samples collected from April 1962 to January 1991. Thick, horizontal blue line represents median value shown along with estimates for 5 percent measurement error (dashed blue lines). Thick sloping line represents a statistically significant trend (see results in appendix D). Shaded histogram represents annual groundwater withdrawals from WW-2 (see appendix E, fig. E-26 for withdrawal values). 
No specific conductance measurements were made for nearly a 10-year period after pumping ceased in 1990. When the well was resampled by bailing in September 2001, specific conductance of water in the casing had decreased to a value of $326 \mu \mathrm{S} / \mathrm{cm}$ and continued to decrease progressively in subsequent bailed samples to $270 \mu \mathrm{S} / \mathrm{cm}$ in the 2005 sample (fig. 27). However, after purging the well in 2006, specific conductance returned to values between 339 and $377 \mu \mathrm{S} / \mathrm{cm}$, which are similar to those obtained during pumping in the 1960s and 1970s.

Concentrations of major ions mimic the temporal patterns for specific conductance (fig. 28). Concentrations of $\mathrm{HCO}_{3}$, $\mathrm{SO}_{4}, \mathrm{Na}, \mathrm{Ca}$, and $\mathrm{Mg}$ increase in samples collected from 1962 to 1991. Parametric and nonparametric tests confirm that these monotonically increasing trends are statistically significant (table 9; appendix D-8). Concentrations of Cl vary outside of the limits expected for analytical uncertainties, but do not define a monotonic trend like the other constituents. In contrast to trends observed during pumping, concentrations of all constituents except for $\mathrm{Cl}$ are substantially lower in bailed samples collected from 2001 to 2005 compared to concentrations from pumped samples obtained in 1991. Concentrations of $\mathrm{Cl}$ for three of the four bailed samples are substantially higher than earlier pumped samples. With the exception of $\mathrm{Na}$, concentrations in the final pumped sample collected in September 2006 approached, but did not necessarily match values obtained in 1991.

Reliable trace element concentration data (appendix C) for samples from WW-2 are limited and do not allow evaluation of trends for major ions. Semiquantitative data for $\mathrm{Fe}, \mathrm{Li}$, and $\mathrm{Mn}$ from the 1960s and later are too imprecise or infrequent to characterize trends for pumped samples. None of the bailed samples reported trace element or isotope analyses. Data for a single sample of water pumped on September 7, 2006, reported concentrations of Mn, Sr, and U that are comparable to values obtained from earlier pumped samples. Analyses of $\delta^{2} \mathrm{H}$ and $\delta^{18} \mathrm{O}$ are only available for four pumped samples collected in 1982, 1989, 1990, and 2006 (appendix C). Values of $\delta^{2} \mathrm{H}$ for all four samples range from -102 to $104 \%$ and are analytically identical, assuming an analytical error of $2 \%$ o (fig. 22). Values for $\delta^{18} \mathrm{O}$ vary more widely, but do not show patterns of variation related to the pump history and chemical changes described previously.

Temporal trends for specific conductance and major ion concentrations are consistent with mixing between carbonate and volcanic aquifers in WW-2. Water produced during the active withdrawal period from 1962 to 1990 had compositions that were enriched in $\mathrm{Ca}$ and $\mathrm{SO}_{4}$, and progressively tapped water containing higher total dissolved solids with time. After a 10 -year period of inactivity, water bailed from the casing became more dilute and contained more constituents typically associated with the volcanic aquifer (that is, $\mathrm{Cl}$ ). The proportion of water contributed from the volcanic aquifer remained abundant in bailed samples through 2005. However, purging of $0.035 \mathrm{Mgal}$ in September 2006 was sufficient to remove much of the volcanic water that had accumulated in the well. As a result, water sampled after pumping was mostly derived from the carbonate aquifer. It is not clear whether these results represent the local effects of contamination due to a leaky casing, or whether they represent a general shift in composition of the shallow aquifer when not stressed by pumping. 

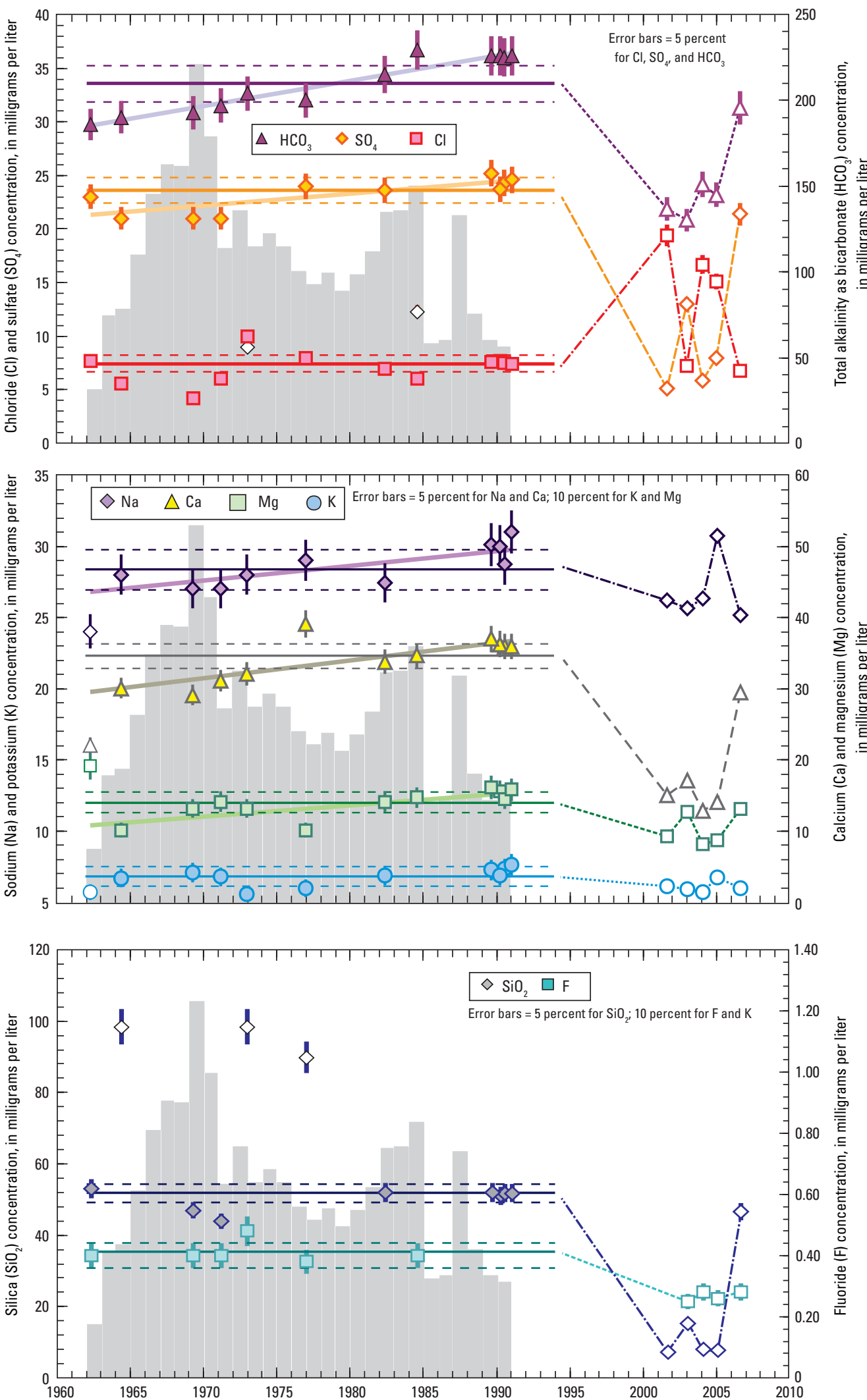

Figure 28. Temporal variations in major-ion concentrations for water samples collected from WW-2, Nevada National Security Site, Nye County, Nevada. Filled symbols represent data from appendix B used to calculate trend analyses and quantitative statistics for samples collected from April 1962 to January 1991 (see results in appendix D and appendix F, respectively). Open symbols represent outliers and were not included in numerical evaluations. Solid horizontal lines represent median concentration values shown along with estimated measurement error (dashed horizontal lines) using the same values given for error bars on individual analyses. Thick sloping lines represent statistically significant trends. Shaded histogram represents annual groundwater withdrawals from WW-2 (see appendix E, fig. E-26 for withdrawal values). 


\section{WW-3}

Borehole Description and Water Withdrawals: WW-3 is in southern Yucca Flat in Area 6 of the NNSS (fig. 1; table 1). The borehole was drilled to a depth of 1,800 ft and completed as a supply well in March 1952. The single completion in the borehole, well $W W-3$ (1800 ft), is cased to a depth of 1,765 ft with a slotted zone from 1,535 to 1,765 ft. The annular space between the casing and borehole is open from at least $1,209 \mathrm{ft}$ to the bottom of the hole (appendix E, fig. E-28). The mean water level in the well is at a depth of 1,539 ft below land surface.

The borehole penetrates alluvium from 0 to $1,530 \mathrm{ft}$, nonwelded tuff from 1,530 to 1,685 ft, sandstone from 1,685 to $1,765 \mathrm{ft}$, and conglomerate from 1,765 to $1,800 \mathrm{ft}$ (appendix E, fig. E-28; Wood, 2007). Water produced from WW-3 is mostly from the sandstone underlying the welded tuff (S.R. McKinney and Son, written commun., 1952), which is part of the older alluvial aquifer HSU (Bechtel Nevada, 2006; Fenelon and others, 2010, appendix 3).

WW-3 was drilled to help guide the location of other supply wells in Yucca Flat and later was used as a supply well (Moore, 1961, p. 8; U.S. Department of Energy, 1996b, p. 1-1). Approximately $203 \mathrm{Mgal}$ of water were withdrawn from the well between 1952 and 1970, with about 87 percent of the production occurring during a 9 year period from 1958 to 1968 (fig. 29). Pumping ceased in 1970 because of high iron contents that likely were caused by corrosion of the well casing (U.S. Department of Energy, 1996b, p. 11). The well was recompleted in 1992 for water-level monitoring; however, no water-quality samples have been collected from the recompleted well.

Water Quality: Water from WW-3 is intermediate in composition between water typical of volcanic and carbonate aquifers. Analyses plot in a tight cluster on a trilinear plot of major ions (appendix E, fig. E-30), with $\mathrm{Na}$ and $\mathrm{HCO}_{3}$ being the dominant ions. However, unlike water from many volcanic aquifers at the NNSS, water from WW-3 contains substantial amounts of Ca and Mg.

Specific conductance was measured during the 12-year period from April 1957 to April 1969, which spanned most of the period of pumping at WW-3. Specific conductance ranged from 345 to $386 \mu \mathrm{S} / \mathrm{cm}$, with a median value of $373 \mu \mathrm{S} / \mathrm{cm}$ (excluding the initial sample from April 1957, which had an anomalous value of $421 \mu \mathrm{S} / \mathrm{cm}$; fig. 29). All sample values from September 1957 to April 1969 are within the limits expected for analytical error about the median value and show no obvious systematic trend with time. Parametric and nonparametric tests confirm the absence of systematic trends in conductance with time (table 10; appendix D-9). These data indicate that total dissolved ion concentrations in water pumped from WW-3 remained constant throughout the period of groundwater withdrawals.

Major ions analyzed in water samples from the same 12-year period also have concentrations that typically are within the range expected for analytical uncertainties associated with calculated median values (fig. 30). Results reported for the sample collected in November 1959 are anomalous for most elements, and considered the likely consequence of sample contamination or mix up. As a result, chemical data for this sample are not included in the calculation of medians or regressions. Systematic shifts in concentration are not apparent, and parametric and nonparametric tests confirm the absence of systematic trends with time (table 10; appendix D-9). Concentrations of $\mathrm{SO}_{4}$ and $\mathrm{SiO}_{2}$ are slightly lower for the samples collected in 1964 and 1969 than for earlier samples; however, the data do not have a statistically significant trend at the 95-percent confidence level. Although visual examination suggests that concentrations of $\mathrm{K}, \mathrm{SO}_{4}$, and $\mathrm{SiO}_{2}$ may have a step-change in concentration after 1963, the data are considered too sparse to allow more rigorous evaluation of this difference. Given the absence of shifts for the other constituents and the lack of an overall change in pre- and post-1963 pumping, the small differences in $\mathrm{K}, \mathrm{SO}_{4}$, and $\mathrm{SiO}_{2}$ are considered to be unlikely indicators of substantive shifts in WW-3 chemistry. As a result, major ion chemistry, similar to specific conductance, is interpreted to have remained constant for the period of groundwater withdrawals.

Trace element concentration data for samples from WW-3 consist largely of $\mathrm{Fe}, \mathrm{Sr}$, and $\mathrm{U}$. These determinations are only semiquantitative and show large variations that do not allow evaluation of possible trends. No isotope data are available for samples from WW-3. 


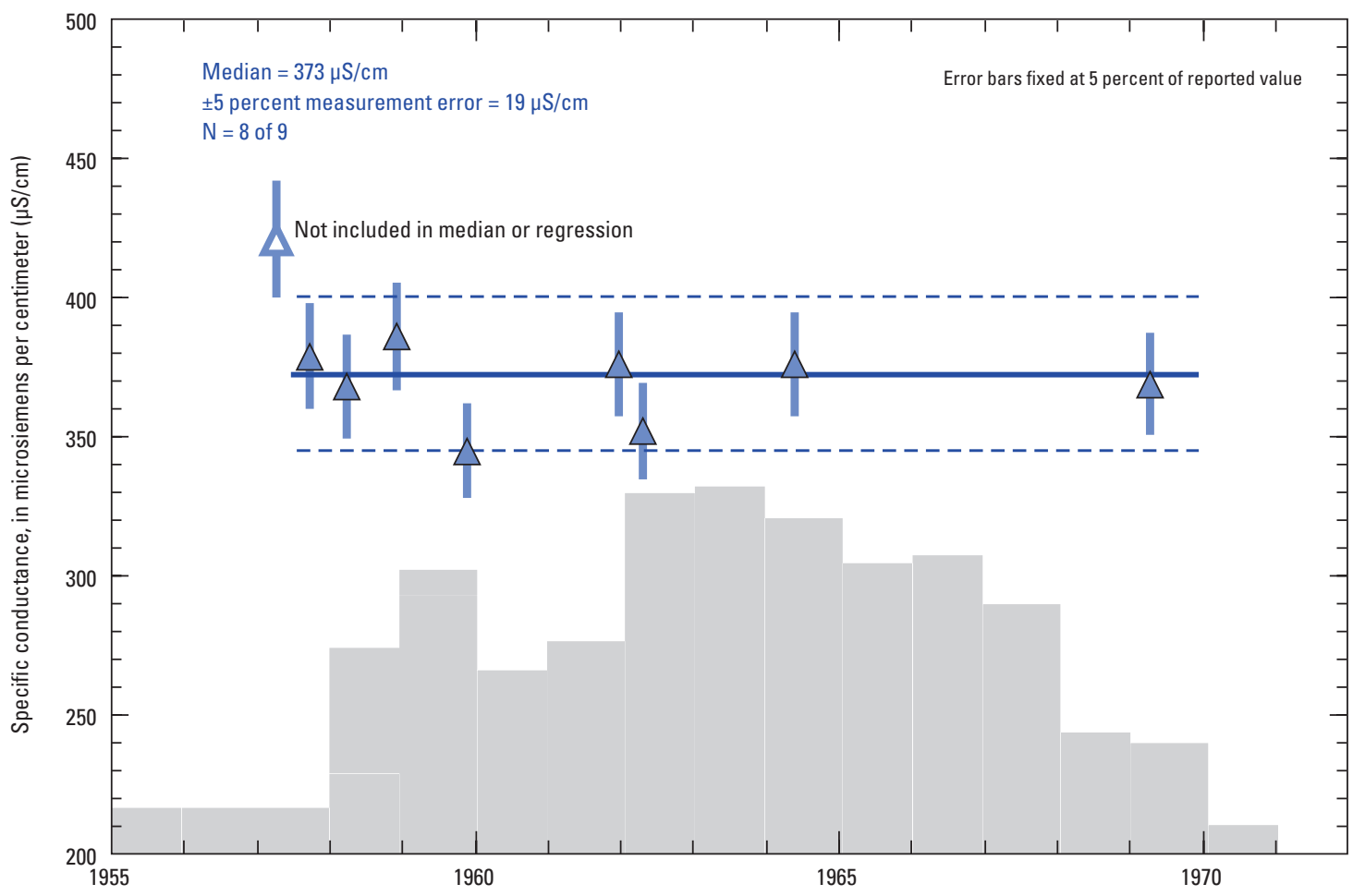

Figure 29. Temporal variations in specific conductance for water samples collected from WW-3, Nevada National Security Site, Nye County, Nevada. Specific conductance data from appendix A used to calculate the median value and trend analysis are shown as filled symbols. Open symbols represent outliers and were not included in numerical evaluations. Thick, horizontal blue line represents the median value shown along with estimates for 5 percent measurement error (dashed blue lines). Shaded histogram represents annual groundwater withdrawals from WW-3 (see appendix E, fig. E-29 for withdrawal values).

Table 10. Results of trend analyses for major constituents in water pumped from WW-3, Nevada National Security Site, Nye County, Nevada, between April 4, 1957, and April 16, 1969.

[A bbreviations: MK, Mann-Kendall test; SES, Sen's estimator of slope test; LR, linear regression;-, not applicable]

\begin{tabular}{lcccccc}
\hline \multicolumn{1}{c}{ Constituent } & $\begin{array}{c}\text { Total } \\
\text { samples }\end{array}$ & $\begin{array}{c}\text { Normality } \\
\text { tests }\end{array}$ & $\begin{array}{c}\text { MK } \\
\text { result }\end{array}$ & $\begin{array}{c}\text { SES } \\
\text { result }\end{array}$ & $\begin{array}{c}\text { Residual } \\
\text { normality } \\
\text { test }\end{array}$ & $\begin{array}{c}\text { LR } \\
\text { result }\end{array}$ \\
\hline Conductivity & 7 & passed & no trend & no trend & passed & no trend \\
Calcium $(\mathrm{Ca})$ & 7 & passed & no trend & no trend & passed & no trend \\
Magnesium $(\mathrm{Mg})$ & 7 & passed & no trend & no trend & passed & no trend \\
Sodium $(\mathrm{Na})$ & 7 & passed & no trend & no trend & passed & no trend \\
Potassium $(\mathrm{K})$ & 7 & passed & no trend & no trend & failed & - \\
Chloride $(\mathrm{Cl})$ & 7 & passed & no trend & no trend & passed & no trend \\
Bicarbonate $\left(\mathrm{HCO}_{3}\right)$ & 7 & passed & no trend & no trend & passed & no trend \\
Sulfate $\left(\mathrm{SO}_{4}\right)$ & 7 & passed & no trend & no trend & passed & no trend \\
Silicon dioxide $\left(\mathrm{SiO}_{2}\right)$ & 7 & passed & no trend & no trend & passed & no trend \\
Fluoride $(\mathrm{F})$ & 7 & failed & no trend & no trend & - & - \\
\hline
\end{tabular}



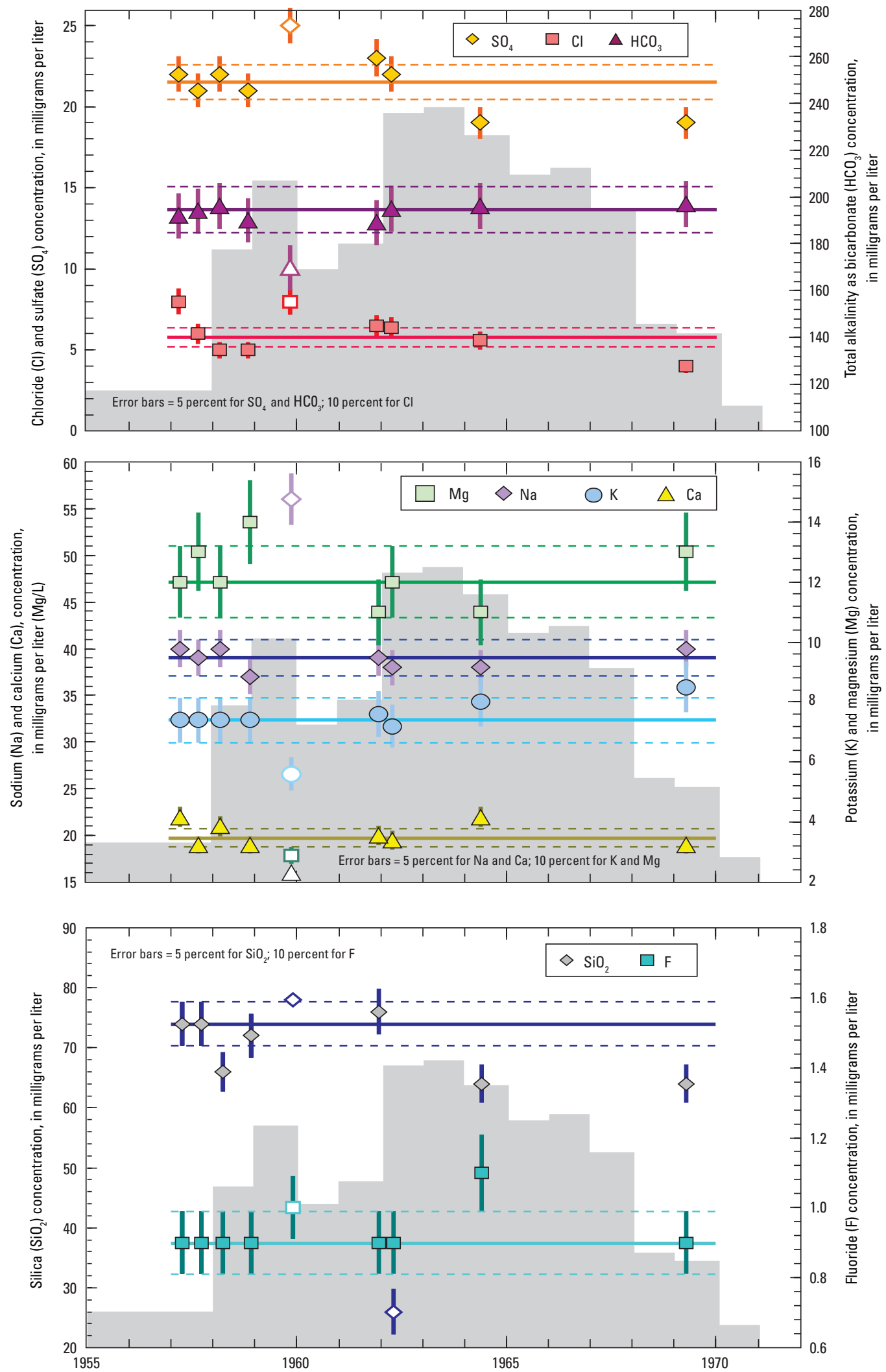

Figure 30. Temporal variations in major-ion concentrations for water samples collected from WW-3, Nevada National Security Site, Nye County, Nevada. Filled symbols represent data from appendix B used to calculate trend analyses and quantitative statistics (see results in appendix $\mathrm{D}$ and appendix $\mathrm{F}$, respectively). Open symbols represent outliers and were not included in numerical evaluations. Solid horizontal lines represent median concentration values shown along with estimated measurement error (dashed horizontal lines) using the same values given for error bars on individual analyses. Shaded histogram represents annual groundwater withdrawals from WW-3 (see appendix E, fig. E-29 for withdrawal values). 


\section{WW-4}

Borehole Description and Water Withdrawals: WW-4 is at the northern end of Frenchman Flat in Area 6 of the NNSS (fig. 1; table 1). The borehole was drilled to a depth of 1,479 ft and completed as a supply well in November 1981. The single completion in the borehole, well $W W-4$, is cased to a depth of 1,438 ft with a slotted interval from 942 to $1,436 \mathrm{ft}$. The annular space between the casing and borehole is open from 115 to $898 \mathrm{ft}$, and gravel packed from 898 to $1,438 \mathrm{ft}$ (appendix E, fig. E-31). The mean water level in the well is at a depth of $837 \mathrm{ft}$ below land surface.

The borehole penetrates alluvium from 0 to $520 \mathrm{ft}$, and alternating layers of welded and nonwelded tuffs from 520 to 1,466 ft (Wood, 2007) that are mostly associated with the Timber Mountain and Paintbrush lithostratigraphic units (appendix E, fig. E-31). Most water is produced from the fractured, welded tuffs, present from 940 to 1,340 ft (Laczniak and others, 1996, p. 25; Wood, 2007), that make up the Timber Mountain welded tuff aquifer and Topopah Spring aquifer HSUs (Bechtel Nevada, 2005; Fenelon and others, 2010, appendix 3).

WW-4 was constructed to supply water for activities in Yucca Flat. The well was pumped briefly in 1981 and moreor-less continuously beginning in April 1983. Since then about 1,100 Mgal of water have been withdrawn from the well (appendix E, fig. E-32A), with about 70 percent of the water withdrawn from 1983 to 1994. In July 1994, nearby WW-4A also began supplying water. As a result, pumping in WW4 decreased, but did not stop (appendix E, fig. E-32B).
Water Quality: Water from WW-4 has compositions that are dominated by $\mathrm{Na}$ and $\mathrm{HCO}_{3}$ ions (appendix B) ), which is consistent with a source from the volcanic aquifer. However, $\mathrm{Ca}$ and $\mathrm{SO}_{4}$ components are higher in WW-4 than in many other groundwater samples from volcanic aquifers at the NNSS. Compositions of individual analyses cluster on a trilinear plot of major ions in the cation and anion fields (appendix E, fig. E-33), reflecting the limited variability of samples. A higher concentration of alkali-earth elements (Ca and Mg) in WW-4 water could result from a larger component of local recharge or flow through welded tuff aquifers having low zeolite contents with limited capacities for cation exchange.

Specific conductance measured over the 25-year period from November 1981 to October 2005, which includes most of the pumping at WW-4, ranges from 400 to $430 \mu \mathrm{S} / \mathrm{cm}$ with a median value of $414 \mu \mathrm{S} / \mathrm{cm}$ (fig. 31). All measurements are within the limits expected for analytical error about the median value, and no systematic trend with time is apparent. Parametric and nonparametric tests confirm the absence of systematic shifts with time (table 11; appendix D-10), despite the large variations (nearly a factor of 10) in annual water withdrawals from WW-4 (fig. 31). These data indicate that dissolved ion concentrations in WW-4 water remained constant regardless of the groundwater withdrawal history of the well.

Major ion concentrations in water sampled from WW-4 between 1981 and 2006 commonly are within expected analytical uncertainties of the calculated median values (fig. 32).

Table 11. Results of trend analyses for major constituents in water pumped from WW-4, Nevada National Security Site, Nye County, Nevada, between December 1, 1981, and July 25, 2006.

[A bbreviations: MK, Mann-Kendall test; SES, Sen's estimator of slope test; LR, linear regression;-, not applicable]

\begin{tabular}{lcclccc}
\hline \multicolumn{1}{c}{ Constituent } & $\begin{array}{c}\text { Total } \\
\text { samples }\end{array}$ & $\begin{array}{c}\text { Normality } \\
\text { tests }\end{array}$ & $\begin{array}{c}\text { MK } \\
\text { result }\end{array}$ & $\begin{array}{c}\text { SES } \\
\text { result }\end{array}$ & $\begin{array}{c}\text { Residual } \\
\text { normality } \\
\text { test }\end{array}$ & $\begin{array}{c}\text { LR } \\
\text { result }\end{array}$ \\
\hline Conductivity & 17 & passed & no trend & no trend & passed & no trend \\
Calcium $(\mathrm{Ca})$ & 15 & passed & increasing & no trend & passed & no trend \\
Magnesium $(\mathrm{Mg})$ & 16 & passed & no trend & no trend & passed & no trend \\
Sodium $(\mathrm{Na})$ & 14 & passed & decreasing & decreasing & failed & - \\
Potassium $(\mathrm{K})$ & 14 & failed & no trend & no trend & - & - \\
Chloride $(\mathrm{Cl})$ & 16 & passed & increasing & no trend & passed & inconclusive \\
Bicarbonate $\left(\mathrm{HCO}_{3}\right)$ & 15 & failed & no trend & no trend & - & - \\
Sulfate $\left(\mathrm{SO}_{4}\right)$ & 16 & passed & no trend & no trend & passed & no trend \\
Silicon dioxide $\left(\mathrm{SiO}_{2}\right)$ & 14 & passed & no trend & decreasing & passed & no trend \\
Fluoride $(\mathrm{F})$ & 15 & passed & decreasing & decreasing & failed & - \\
\hline
\end{tabular}




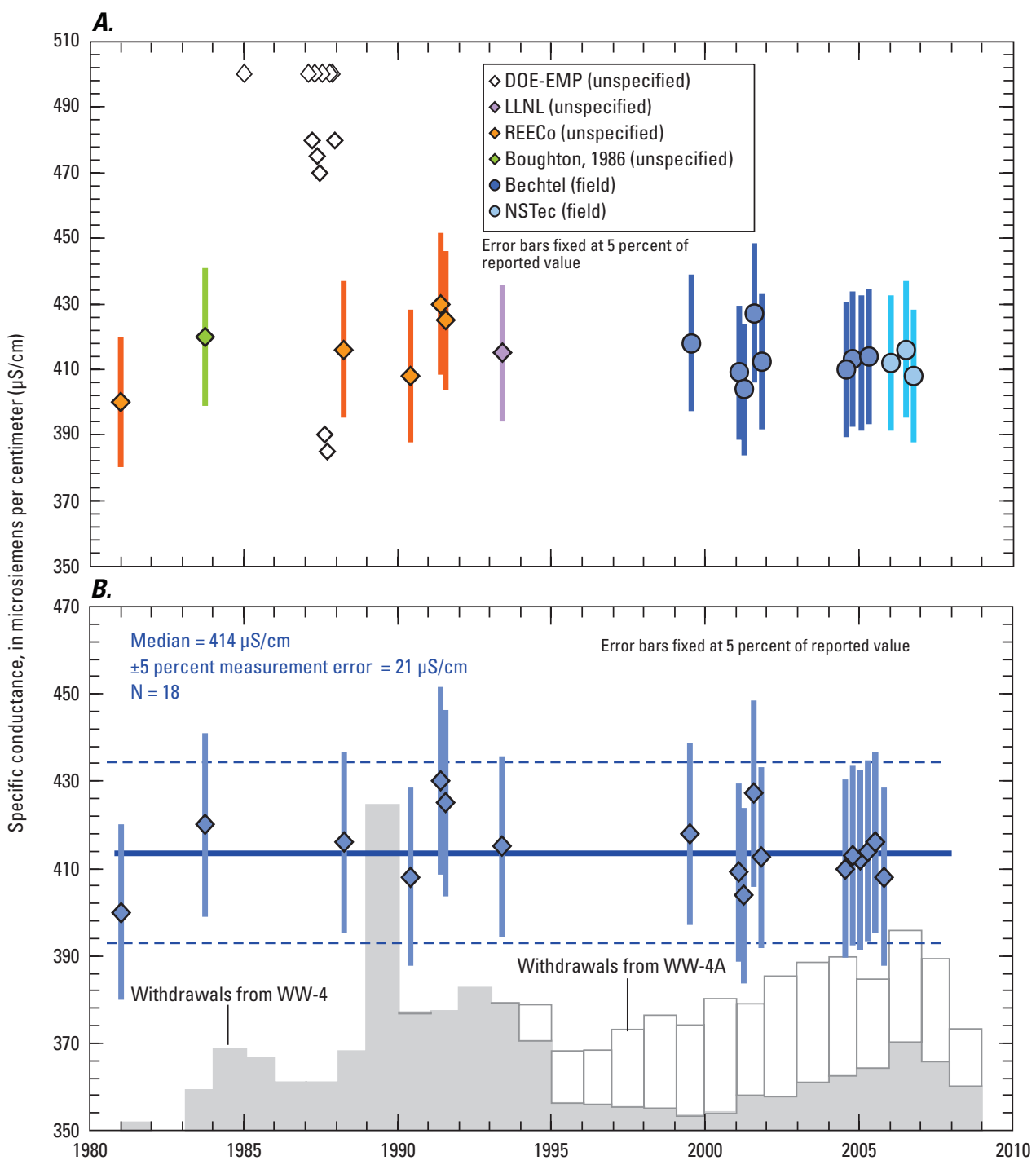

Figure 31. Temporal variations in specific conductance for water samples collected from WW-4, Nevada National Security Site, Nye County, Nevada. (A) All available specific conductance data from appendix A, identified by source including Bechtel, Bechtel Nevada; Boughton, 1986; DOE-EMP, Department of Energy Environmental Monitoring Program; LLNL, Lawrence Livermore National Laboratory; NSTec, National Security Technologies, LLC; and REECo, Reynolds Electrical \& Engineering Co., Inc. Reported measurements were either made in the field, the laboratory, or were unspecified in the database. (B) Specific conductance data used to calculate the median value and trend analysis. Thick, horizontal blue line represents median value shown along with estimates for 5 percent measurement error (dashed blue lines). Shaded histogram represents annual groundwater withdrawals from WW-4 and the unshaded histogram represents withdrawals from nearby WW-4A (see appendix $E$, fig. E-32 for withdrawal values). 

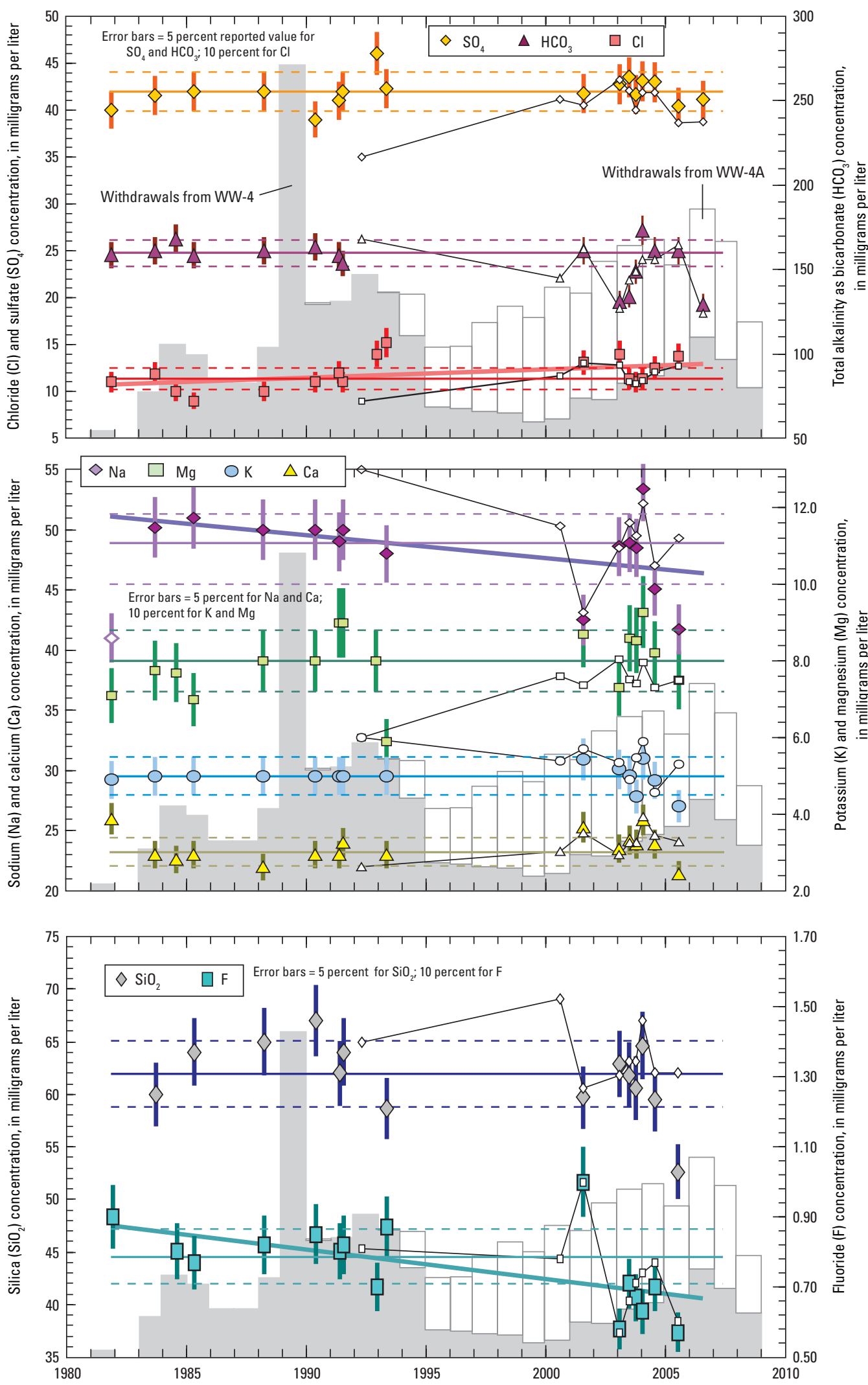

Figure 32. Temporal variations in major-ion concentrations for water samples collected from WW-4, Nevada National Security Site, Nye County, Nevada. Filled symbols represent data from appendix B used to calculate trend analyses and quantitative statistics (see results in appendix $D$ and appendix $F$, respectively). Solid horizontal lines represent median concentration values shown along with estimated measurement error (dashed horizontal lines) using the same values given for error bars on individual analyses. Thick sloping lines represent statistically significant trends. Concentrations of WW-4A samples (small open symbols connected by thin black lines) are shown for comparison, but treated separately in figure 35. Shaded histogram represents annual groundwater withdrawals from WW-4 and the unshaded histogram represents withdrawals from nearby WW-4A (see appendix E, fig. E-32 for withdrawal values). 
However, a number of elements $\left(\mathrm{HCO}_{3}, \mathrm{Na}, \mathrm{K}, \mathrm{Ca}\right.$, and F) show more scatter in samples collected from 2001 to 2006 (after completion and pumping of WW-4A) than earlier samples. Variability for a number of constituents satisfies the requirements for normal distributions (table 11; appendix D-10). Consequently, parametric test results are considered more robust in these cases. Results for most constituents confirm the absence of systematic trends, with the possible exceptions of $\mathrm{Na}, \mathrm{Cl}$, and $\mathrm{F}$. Both nonparametric tests indicate a systematic decreasing trend in $\mathrm{Na}$; however, this result is affected by large amounts of scatter in samples collected in the 2000s. Concentrations of $\mathrm{Cl}$ over this same period are not as noisy as $\mathrm{Na}$. The more recent samples tend to have higher $\mathrm{Cl}$ concentrations than samples collected in the 1980s, but results for parametric and nonparametric trend analysis are inconclusive (table 11). Fluoride shows an overall decreasing trend with time. Concentrations of $\mathrm{Ca}$, and $\mathrm{SiO}_{2}$ are considered to exhibit no trend on the basis of linear regression results, even though results of nonparametric tests are mixed.

Samples of water collected at similar times from WW-4 and WW-4A after 2000 have nearly identical concentrations and patterns of variation, with the exception of the first sample collected from WW-4A in 1992 (fig. 32). It is unclear if the similar patterns of variation obtained for paired samples are caused by real variations in groundwater chemistry or are the result of parallel analytical artifacts for samples analyzed by the same laboratory. Despite the cause of these variations, similar results for paired samples indicate that water pumped from WW-4 and WW-4A is well connected hydraulically. Visual examination indicates that major-ion concentrations are not correlated with changes in withdrawal history in an obvious way; however, samples were not collected from 1995 to 2000 when withdrawals from $\mathrm{WW}-4$ were minimal and WW-4A was pumping continuously (fig. 32). The increased amount of scatter in WW-4 water compositions sampled after 2000 possibly is caused by pumping from WW-4A.

Trace element concentrations reported for water samples from WW-4 since the well was first pumped in 1981 have remained below detection limits $(\mathrm{Cd}, \mathrm{Cr}, \mathrm{Hg}, \mathrm{Pb})$ or are too imprecisely determined (B, Ba, Fe, Mn, Se, Zn) for use in evaluating temporal trends (appendix C). Analyses of $\delta^{2} \mathrm{H}$ and $\delta^{18} \mathrm{O}$ reported for a single sample collected in 1983 are isotopically "heavier" than most other water samples from the NNSS (fig. 33). Values of $-94 \%$ for $\delta^{2} \mathrm{H}$ and $-12.6 \%$ for $\delta^{18} \mathrm{O}$ are indicative of a water source that includes greater amounts of relatively young, local recharge. A statistically identical $\delta^{18} \mathrm{O}$ value of $-12.5 \%$ was obtained from a sample collected 10 years later in 1993. The relatively high radiocarbon concentration (18.2 percent modern carbon) reported for the 1993 sample is consistent with the isotopically "heavy" $\mathrm{H}$ and $\mathrm{O}$ isotope data, and suggests that WW-4 water contains a larger component of young recharge relative to groundwater from other volcanic or alluvial aquifers sampled in Frenchman Flat boreholes (UE-5c WW, WW-5A, WW-5B, and WW-5C; appendix C).

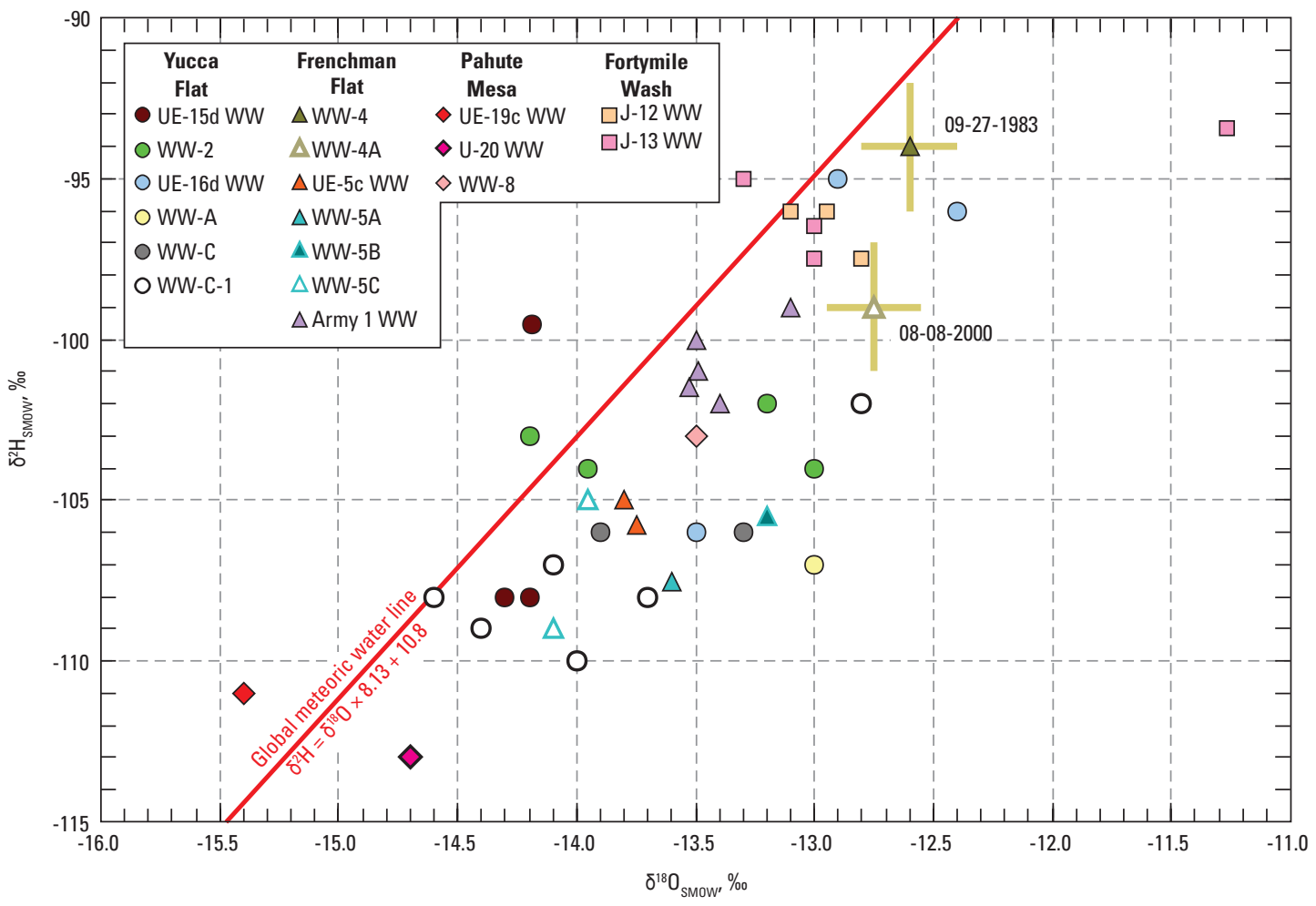

Figure 33. Isotopic compositions of hydrogen and oxygen for water samples from WW-4 and WW-4A in northern Frenchman Flat, and data from other water-supply wells at the Nevada National Security Site, Nye County, Nevada. 


\section{WW-4A}

Borehole Description and Water Withdrawals: WW-4A is at the northern end of Frenchman Flat in Area 6 of the NNSS, approximately 1,200 ft southwest of WW-4 (fig. 1; table 1). The borehole was drilled to a depth of $1,517 \mathrm{ft}$ and completed as a supply well in February 1990. The single completion in the borehole, well $W W-4 A$, is cased to a depth of $1,501 \mathrm{ft}$, with two slotted intervals from 1,066 to $1,281 \mathrm{ft}$ and 1,365 to 1,457 ft (appendix E, fig. E-34). The annular space between the casing and borehole is open from 536 to $944 \mathrm{ft}$ and gravel packed from 944 to 1,502 ft. The mean water level in the well is at a depth of $838 \mathrm{ft}$ below land surface.

The borehole penetrates alluvium from 0 to $750 \mathrm{ft}$ and alternating layers of nonwelded and welded tuffs from 750 to $1,517 \mathrm{ft}$ (Wood, 2007), similar to the stratigraphy penetrated by WW-4 (appendix E, fig. E-34). Most water is produced from the fractured, welded tuffs present between 1,050 and 1,450 ft (Gillespie and others, 1996, p. 40, 44; Wood, 2007) that make up the Timber Mountain welded tuff aquifer and Topopah Spring aquifer HSUs (Bechtel Nevada, 2005; Fenelon and others, 2010, appendix 3).

WW-4A was constructed as a supply well and pumped intermittently from December 1993 to June 1994, and continuously since then (appendix E, fig. E-35A). Almost $790 \mathrm{Mgal}$ of water have been withdrawn from the well since pumping began.
Water Quality: Water samples from WW-4A have compositions that are similar to those described for WW-4. Data for the two wells overlap within the same cluster on a trilinear plot of major ions (appendix E, fig. E-36) indicating a limited range of compositions and the same source water.

Specific conductance data are only available for groundwater sampled from WW-4A since August 2000, with the exception of a single measurement made in April 1992 (fig. 34). The median value for measurements of WW-4A samples $(407 \mu \mathrm{S} / \mathrm{cm})$ is slightly lower than the value obtained for WW-4 samples (414 $\mu \mathrm{S} / \mathrm{cm})$; however, two-sample and paired t-tests of data collected from both wells on the same day indicate that means for samples from WW-4 and WW-4A are indistinguishable at the 95-percent confidence level $(\mathrm{N}=9$; mean and $1 \sigma$ values of $413.1 \pm 6.3 \mu \mathrm{S} / \mathrm{cm}$ for $\mathrm{WW}-4$ and $407.3 \pm 7.0 \mu \mathrm{S} / \mathrm{cm}$ for $\mathrm{WW}-4 \mathrm{~A}$ with $\mathrm{p}$ values of 0.113 and 0.143 , respectively, indicating that the null hypothesis of equal means cannot be rejected). A nonparametric Mann-Whitney test of the two data sets yields the same result, but does distinguish the two data sets as significant at the 92.4 percent confidence level. Parametric and nonparametric tests confirm the absence of systematic trends with time (table 12; appendix D-11) indicating that the amount of total dissolved solids in WW-4A water has not shifted systematically during the period of record. Combined pumping from WW-4 and WW-4A also remained relatively uniform during the period of data collection (fig. 34).

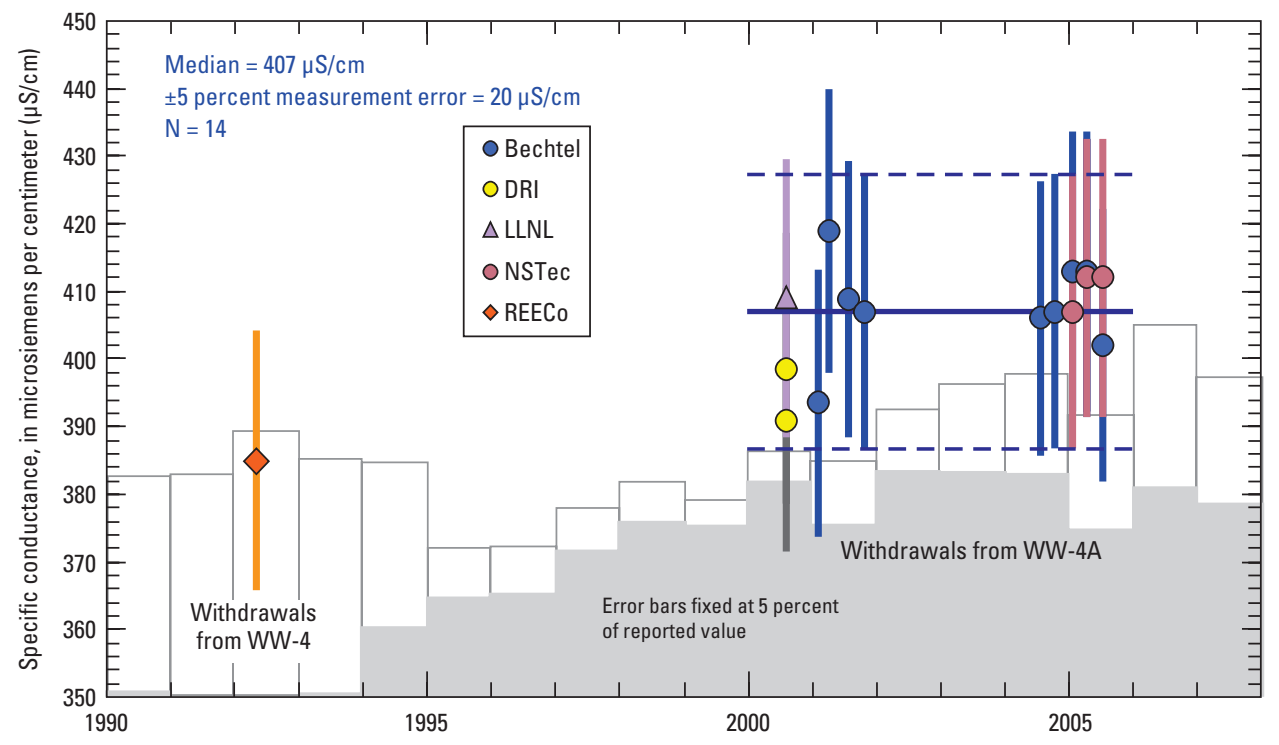

Figure 34. Temporal variations in specific conductance for water samples collected from WW-4A, Nevada National Security Site, Nye County, Nevada. All specific conductance data from appendix A are identified by source and include Bechtel, Bechtel Nevada; DRI, Desert Research Institute; LLNL, Lawrence Livermore National Laboratory; NSTec, National Security Technologies, LLC; and REECo, Reynolds Electrical \& Engineering Co., Inc. Thick, horizontal blue line represents the median value for samples collected from August 2000 to October 2005, shown along with estimates for 5 percent measurement error (dashed blue lines). Shaded histogram represents annual groundwater withdrawals from WW-4A and the unshaded histogram represents withdrawals from nearby WW-4 (see appendix E, fig. E-35 for withdrawal values). 
Table 12. Results of trend analyses for major constituents in water pumped from WW-4A, Nevada National Security Site, Nye County, Nevada, between August 8, 2000, and July 25, 2006.

[Abbreviations: MK, Mann-Kendall test; SES, Sen's estimator of slope test; LR, linear regression]

\begin{tabular}{lclcccc}
\hline \multicolumn{1}{c}{ Constituent } & $\begin{array}{c}\text { Total } \\
\text { samples }\end{array}$ & $\begin{array}{c}\text { Normality } \\
\text { tests }\end{array}$ & $\begin{array}{c}\text { MK } \\
\text { result }\end{array}$ & $\begin{array}{c}\text { SES } \\
\text { result }\end{array}$ & $\begin{array}{c}\text { Residual } \\
\text { normality } \\
\text { test }\end{array}$ & $\begin{array}{c}\text { LR } \\
\text { result }\end{array}$ \\
\hline Conductivity & 11 & passed & no trend & no trend & passed & no trend \\
Calcium $(\mathrm{Ca})$ & 8 & passed & no trend & no trend & passed & no trend \\
Magnesium $(\mathrm{Mg})$ & 8 & passed & no trend & no trend & passed & no trend \\
Sodium $(\mathrm{Na})$ & 8 & passed & no trend & no trend & passed & no trend \\
Potassium $(\mathrm{K})$ & 8 & passed & no trend & no trend & passed & no trend \\
Chloride $(\mathrm{Cl})$ & 10 & passed & no trend & no trend & passed & no trend \\
Bicarbonate $\left(\mathrm{HCO}_{3}\right)$ & 9 & inconclusive & no trend & no trend & inconclusive & no trend \\
Sulfate $\left(\mathrm{SO}_{4}\right)$ & 9 & passed & no trend & no trend & failed & - \\
Silicon dioxide $\left(\mathrm{SiO}_{2}\right)$ & 8 & passed & no trend & no trend & passed & no trend \\
Fluoride $(\mathrm{F})$ & 8 & passed & no trend & no trend & passed & no trend \\
\hline
\end{tabular}

Major ion analyses are available for water sampled from WW-4A since August 2000 and for one sample collected in April 1992 (fig. 35). Major-ion concentrations in samples from WW-4A typically mimic values in samples collected on the same day from WW-4 (fig. 36). In contrast, a number of elements for the April 1992 WW-4A sample, which has no direct WW-4 counterpart, deviate substantially from values in WW-4 water sampled from 1991 to 1993 (fig. 32). Therefore, the 1992 sample from WW-4A likely contains remnants of drilling fluids that were not sufficiently purged from the well. As a result, concentrations reported for this sample date likely do not represent native groundwater at the site.

Water sampled from WW-4A between 2000 and 2006 has major ion concentrations that commonly vary within the range expected for analytical error (fig. 35). No systematic trends are obvious, and parametric and nonparametric tests confirm the absence of systematic shifts in composition (table 12; appendix D-11). Groundwater withdrawals remained reasonably uniform over the 6-year period of geochemical data collection and correlations between major ion fluctuation and withdrawal volumes are not evident (fig. 35).

Trace element concentrations are available for only two samples from WW-4A since pumping began in 1990 (appendix C). One sample, collected in 1992, reports only a limited number of elements (As, B, Ba, Cr, Fe, $\mathrm{Hg}, \mathrm{Mn}$, $\mathrm{Pb}, \mathrm{Se}, \mathrm{Zn}$ ) compared to the more comprehensive suite of 19 elements reported for a sample collected in 2000. Values for $\mathrm{Ba}, \mathrm{Fe}, \mathrm{Mn}$ and $\mathrm{Zn}$ from the 1992 sample are from 4 to more than 100 times larger than values in the 2000 sample. These data are consistent with the major ion data, and suggest that the well had not been adequately purged in 1992. Concentrations of a number of more reliably analyzed elements (As, $\mathrm{Ba}, \mathrm{Li}, \mathrm{Mo} \mathrm{Pb}, \mathrm{Sr}, \mathrm{U}$ ) in the 2000 sample from WW-4A are similar to values reported for water sampled from WW-4 in the early 1990s (appendix C).

Analyses of $\delta^{2} \mathrm{H}$ and $\delta^{18} \mathrm{O}$ reported for a single sample of WW-4A water collected in August 2000 has a $\delta^{18} \mathrm{O}$ value that is analytically identical to the value reported for a 1983 sample from WW-4 (fig. 33). However, its $\delta^{2} \mathrm{H}$ composition is 5\% lighter than the WW-4 value. It is not clear from these two analyses whether this difference is caused by analytical artifacts, by small differences in aquifer sources between the two wells, or by temporal changes that occurred between 1983 and 2000. Concentrations of radiocarbon from both wells are analytically identical (18.3 percent modern carbon for an analysis of WW-4A water in 2000 compared to a value of 18.24 for a 1993 analysis of WW-4 water), and strontium isotopic values are just outside of analytical error $(0.71010 \pm 0.00005$ for the $2000 \mathrm{WW}-4 \mathrm{~A}$ sample compared to $0.71024 \pm 0.00005$ for the $1993 \mathrm{WW}-4$ sample). The isotope data available for WW-4A water samples, although limited, are interpreted to support the likelihood that water pumped from WW-4A and WW-4 has remained unchanged regardless of the volumes of water pumped throughout the 1990s and 2000s from both wells. 

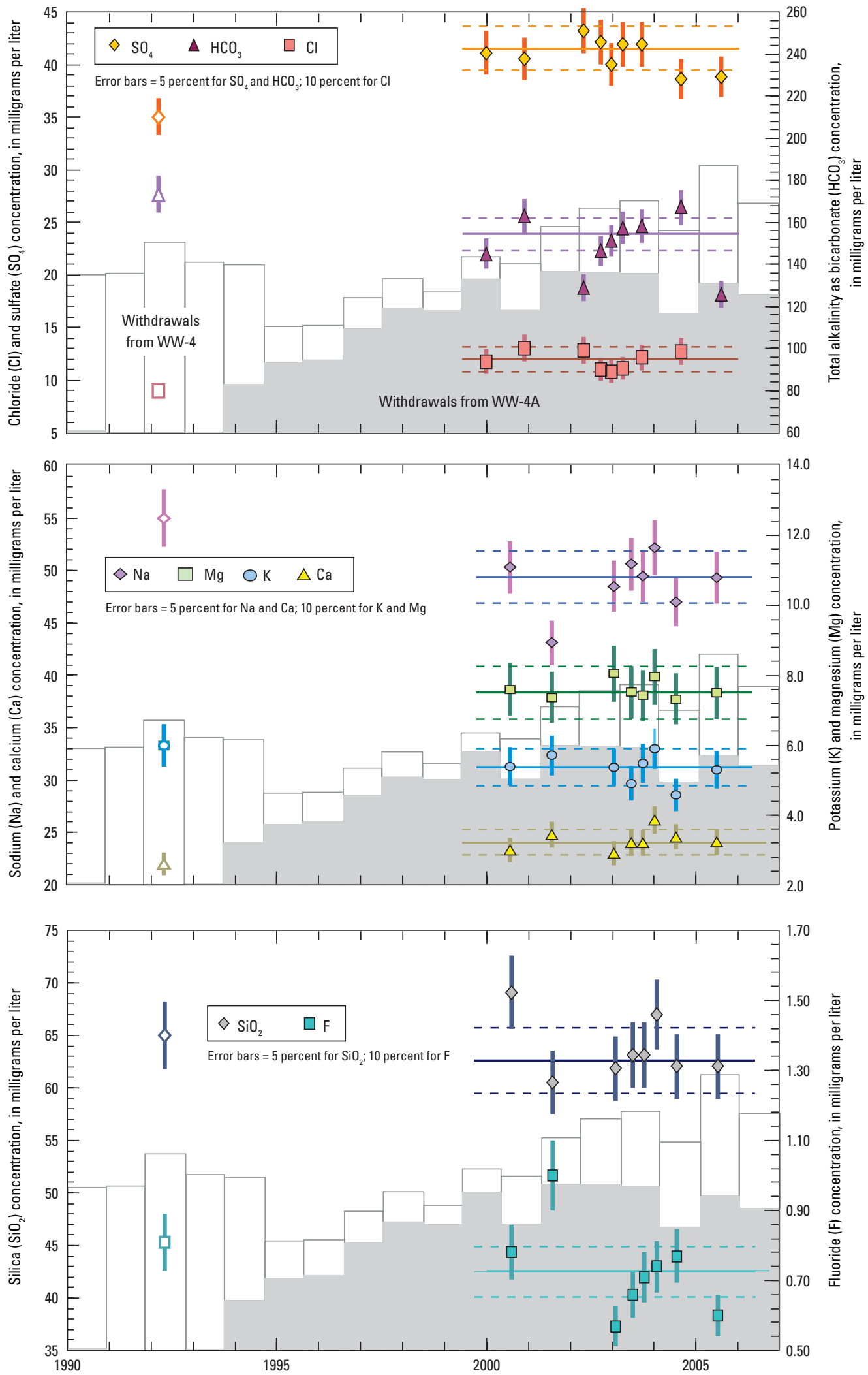

Figure 35. Temporal variations in major-ion concentrations for water samples collected from WW-4A, Nevada National Security Site, Nye County, Nevada. Filled symbols represent data from appendix B used to calculate trend analyses and quantitative statistics (see

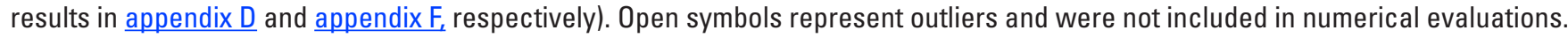
Solid horizontal lines represent median concentration values shown along with estimated measurement error (dashed horizontal lines) using the same values given for error bars on individual analyses. Shaded histogram represents annual groundwater withdrawals from WW-4A and the unshaded histogram represents withdrawals from nearby WW-4 (see appendix E, fig. E-35 for withdrawal values). 


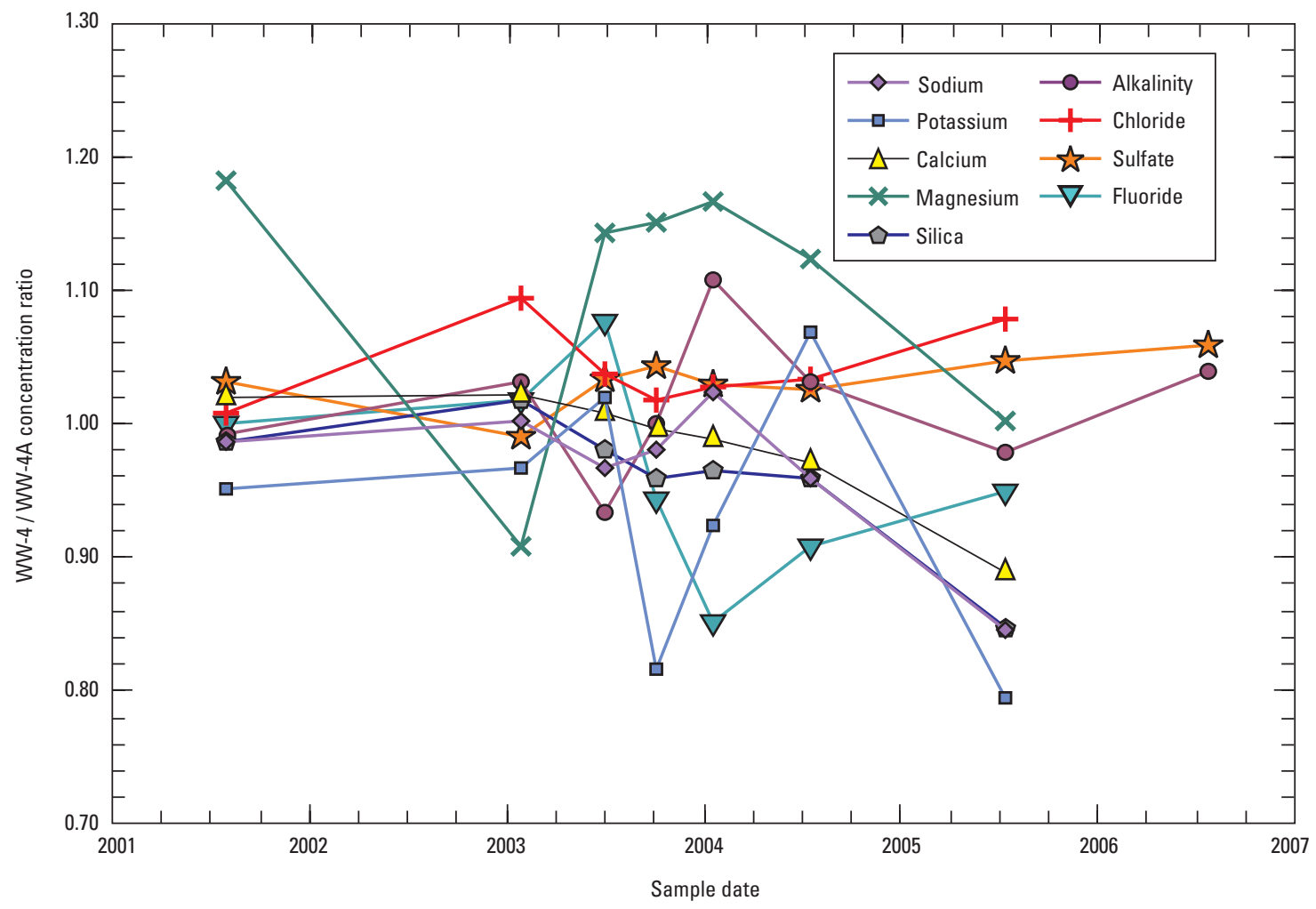

Figure 36. Concentration ratios for water samples collected on the same day from both WW-4 and WW-4A, Nevada National Security Site, Nye County, Nevada. 


\section{WW-5A}

Borehole Description and Water Withdrawals: WW-5A is at the southern end of Frenchman Flat in Area 5 of the NNSS (fig. 1; table 1). The borehole was drilled to a depth of $910 \mathrm{ft}$ and completed as a supply well in March 1951. The single completion in the borehole, well $W W-5 A$, is cased to a depth of $877 \mathrm{ft}$ with a slotted interval from 642 to $877 \mathrm{ft}$. The annular space between the casing and borehole is open from at least $642 \mathrm{ft}$ to the bottom of the hole (appendix E, fig. E-37). The mean water level in the well is at a depth of $710 \mathrm{ft}$ below land surface.

The borehole penetrates alluvium consisting of limestone and quartzite fragments with a silt-clay matrix from 0 to $585 \mathrm{ft}$ and tuffaceous conglomerate consisting of quartzite cobbles, pebbles, and granules embedded in a tuffaceous matrix from 585 to $890 \mathrm{ft}$ (appendix E, fig. E-37; Wood, 2007). Water is produced from the tuffaceous conglomerate (Hood, 1961), which is part of the alluvial aquifer (Bechtel Nevada, 2005; Fenelon and others, 2010, appendix 3).

WW-5A was constructed as a supply well and produced more than 262 Mgal of water from 1951 to 1970 (appendix E, fig. E-38A). Pumping ceased in December 1970, and the pump was removed from the well in July 1971. The well was reconditioned in 1991 for water-level monitoring.

Water Quality: Water from WW-5A has compositions that are extremely enriched in $\mathrm{Na}$ and $\mathrm{HCO}_{3}$, characteristic of highly evolved groundwater from volcanic aquifers. Cations plot in a tight cluster at the $\mathrm{Na}+\mathrm{K}$ apex of a trilinear diagram of major cations (appendix E, fig. E-39). Anions plot in a similarly tight cluster near the $\mathrm{HCO}_{3}$ apex for major anions with only small amounts of $\mathrm{SO}_{4}$ and $\mathrm{Cl}$. These compositions indicate that zeolitized tuffs, which have large capacities for cation exchange, constitute a major sedimentary component in the tuffaceous conglomerate from which the water is derived.

Specific conductance measurements during the period of pumping show a small range of values about a median of $677 \mu \mathrm{S} / \mathrm{cm}$. There is no obvious visual (fig. 37) or statistical (table 13; appendix D-12) evidence of a systematic shift in values determined from April 1957 to June 1964. However, specific conductance measured in two samples collected in August 2000, 29 years after pumping ceased and 9 years after the well was reconditioned, is significantly lower (mean value of $585 \mu \mathrm{S} / \mathrm{cm}$ ) than earlier values (mean value of $668 \mu \mathrm{S} / \mathrm{cm}$ ). More recent data are not available to determine whether the lower conductance value is representative of water in the aquifer, or if this trend has continued.
Major ion data are consistent with the pattern for conductance data. Concentrations in samples collected from 1957 to 1964 scatter about median values and show no visual (fig. 38) or statistical (table 13; appendix D-12) evidence of systematic shifts with time. However, $\mathrm{Na}$ and $\mathrm{HCO}_{3}$ concentrations are lower in the August 2000 sample than previous samples. The decrease in concentrations represent 87 and 85 percent, respectively, of the mean concentrations obtained from samples during the period of pumping. A similar shift in $\mathrm{SiO}_{2}$ is present. These decreases match the drop in specific conductance over this same period. Other constituents vary from this trend; however, they constitute only a small fraction of the total dissolved solids content of WW-5A water. The specific conductance and major ion data suggest a shift toward more dilute compositions of WW-5A water after pumping ceased in 1970. Pumping from nearby boreholes, WW-5B and WW-5C has continued to the present.

Trace element concentration data reported for WW-5A samples are limited because sampling for water quality ended in 1964, despite the well being pumped through 1970. Only a few elemental analyses have been reported for samples collected from 1957 to 1964 (appendix C). A comprehensive suite of trace element analyses were reported for a single sample collected in August 2000, but the lack of reliable data from earlier samples limits the use of these data for evaluating trends. The exception is U concentrations, which typically are reliable, even in older analyses. Uranium concentrations range from 13 to $21 \mu \mathrm{g} / \mathrm{L}$ in samples collected during the period of pumping in WW-5A (the value of $1.7 \mu \mathrm{g} / \mathrm{L}$ for the June 1964 sample is considered spurious), but drop to $7.1 \mu \mathrm{g} / \mathrm{L}$ in the 2000 sample. These data are consistent with a shift to more dilute water, as noted for major ions. However, the large decrease in $U$ concentration (more than one-half of the original concentrations) may indicate that small changes in redox conditions also may be a factor. Degradation of materials introduced into the well tend to reduce the oxidation potential of water present in the borehole and result in lower U solubility.

Water sampled from WW-5A in August 2000 has relatively "light" $\delta^{2} \mathrm{H}$ and $\delta^{18} \mathrm{O}$ values compared to many NNSS groundwater samples (fig. 39, and a low radiocarbon concentration [2.6 percent modern carbon appendix C]). These data, plus the highly evolved, $\mathrm{Na}-\mathrm{HCO}_{3}$ nature of the groundwater, suggest that the source of WW-5A water comes from an alluvial aquifer that was recharged during colder climates of the late Pleistocene. 


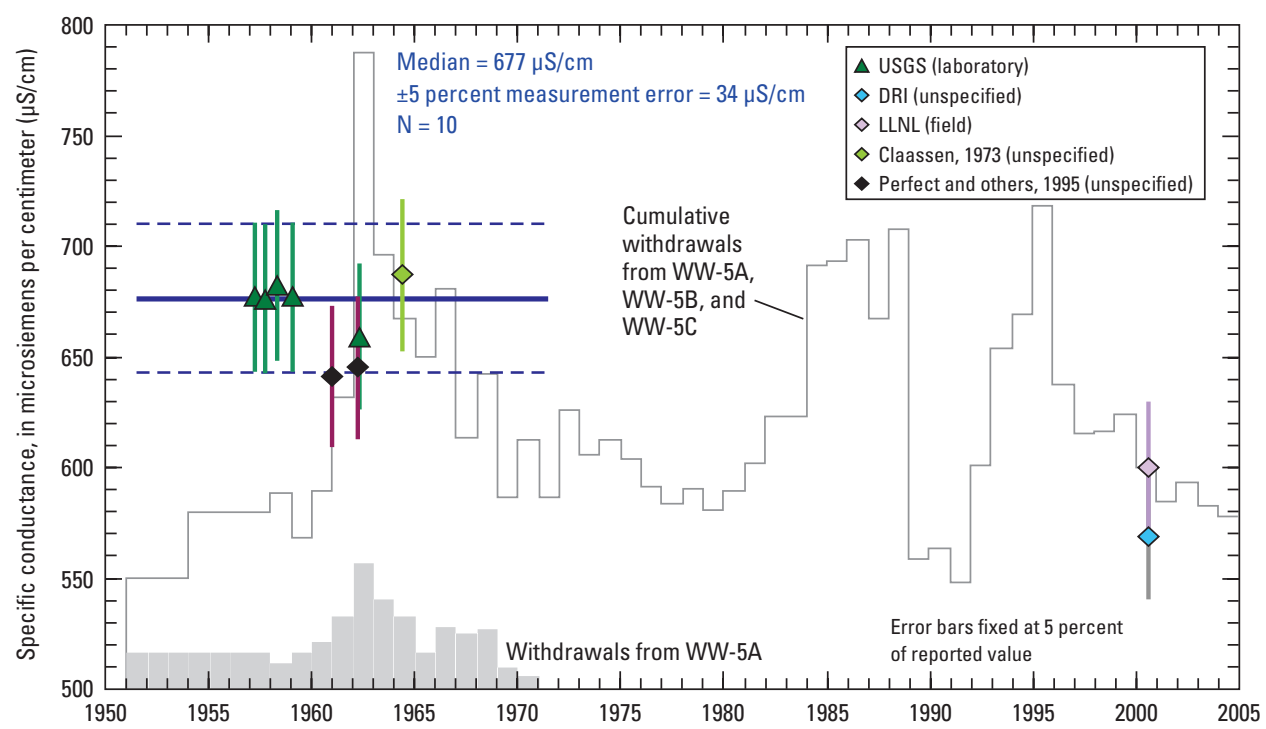

Figure 37. Temporal variations in specific conductance for water samples collected from WW-5A, Nevada National Security Site, Nye County, Nevada. All available specific conductance data from appendix $A$ are identified by source and include Claassen, 1973; DRI, Desert Research Institute; LLNL, Lawrence Livermore National Laboratory; Perfect and others, 1995; and USGS, U.S. Geological Survey. Reported measurements were either made in the field, the laboratory, or were unspecified in the database. Thick, horizontal blue line represents the median value for samples collected from April 1957 to June 1964, shown along with estimates for 5 percent measurement error (dashed blue lines). Shaded histogram represents annual groundwater withdrawals from WW- $5 \mathrm{~A}$, and the unshaded histogram represents cumulative withdrawals from WW- $5 A$, WW- $5 B$, and WW- $5 C$ (see appendix E, fig. E-38 for withdrawal values).

Table 13. Results of trend analyses for major constituents in water pumped from WW-5A, Nevada National Security Site, Nye County, Nevada, between April 4, 1957, and June 4, 1964.

[A bbreviations: MK, Mann-Kendall test; SES, Sen's estimator of slope test; LR, linear regression]

\begin{tabular}{lcccccc}
\hline \multicolumn{1}{c}{ Constituent } & $\begin{array}{c}\text { Total } \\
\text { samples }\end{array}$ & $\begin{array}{c}\text { Normality } \\
\text { tests }\end{array}$ & $\begin{array}{c}\text { MK } \\
\text { result }\end{array}$ & $\begin{array}{c}\text { SES } \\
\text { result }\end{array}$ & $\begin{array}{c}\text { Residual } \\
\text { normality } \\
\text { test }\end{array}$ & $\begin{array}{c}\text { LR } \\
\text { result }\end{array}$ \\
\hline Conductivity & 8 & passed & no trend & no trend & passed & no trend \\
Calcium $(\mathrm{Ca})$ & 7 & passed & no trend & no trend & passed & no trend \\
Magnesium $(\mathrm{Mg})$ & 8 & passed & no trend & no trend & passed & no trend \\
Sodium $(\mathrm{Na})$ & 8 & passed & no trend & no trend & passed & no trend \\
Potassium $(\mathrm{K})$ & 6 & passed & no trend & no trend & passed & no trend \\
Chloride $(\mathrm{Cl})$ & 8 & passed & no trend & no trend & passed & no trend \\
Bicarbonate $\left(\mathrm{HCO}_{3}\right)$ & 8 & passed & no trend & no trend & passed & no trend \\
Sulfate $\left(\mathrm{SO}_{4}\right)$ & 6 & passed & no trend & no trend & passed & no trend \\
Silicon dioxide $\left(\mathrm{SiO}_{2}\right)$ & 8 & passed & no trend & no trend & passed & no trend \\
Fluoride $(\mathrm{F})$ & 7 & passed & no trend & no trend & passed & no trend \\
\hline
\end{tabular}



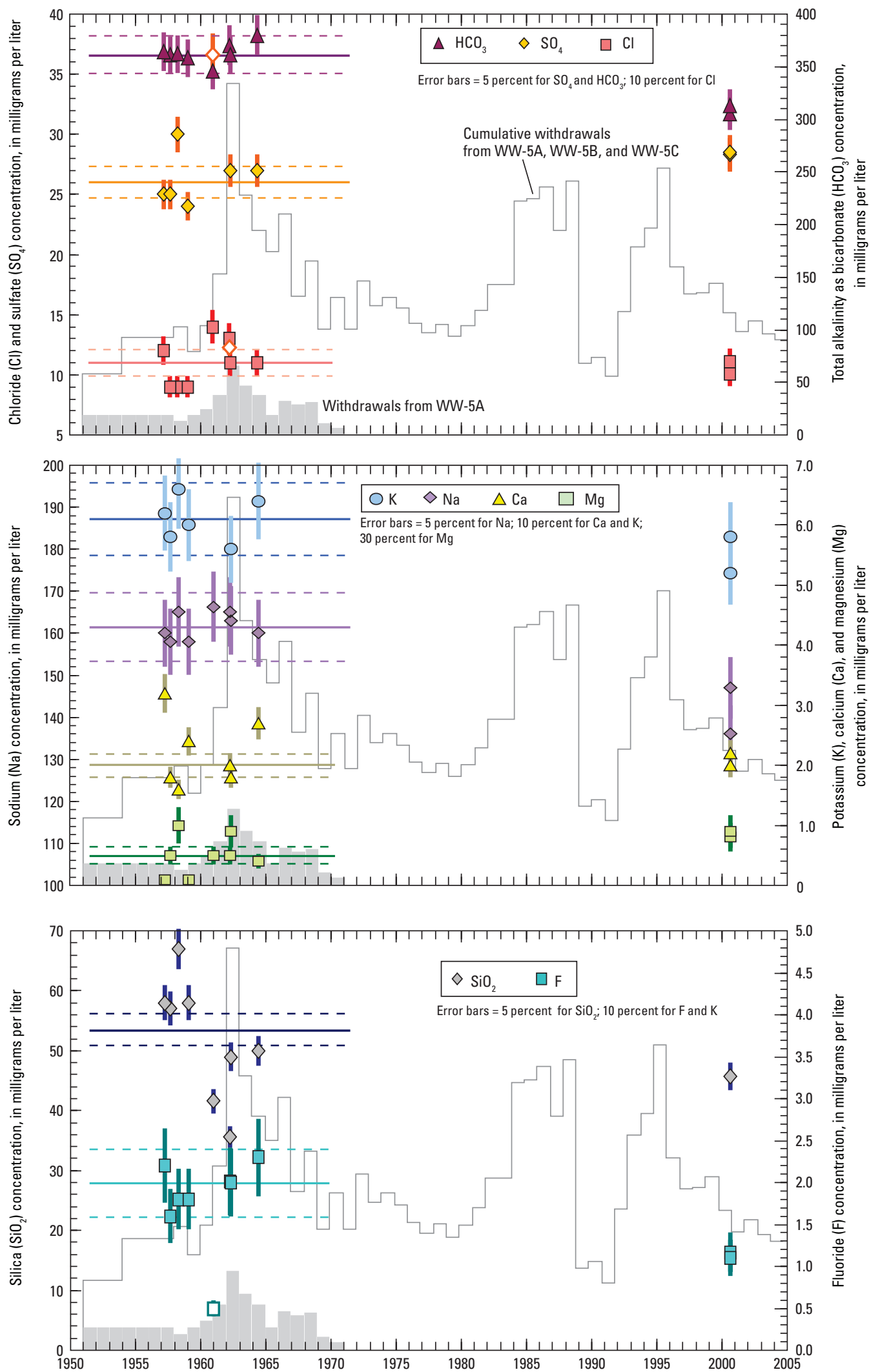

Figure 38. Temporal variations in major-ion concentrations for water samples collected from WW-5A, Nevada National Security Site, Nye County, Nevada. Filled symbols represent data from appendix B used to calculate trend analyses and quantitative statistics for samples collected from April 1957 to June 1964 (see results in appendix D and appendix F, respectively). Open symbols represent outliers and were not included in numerical evaluations. Solid horizontal lines represent median concentration values shown along with estimated measurement error (dashed horizontal lines) using the same values given for error bars on individual analyses. Shaded histogram represents annual groundwater withdrawals from WW-5A, and the unshaded histogram represents cumulative withdrawals from WW-5A, WW-5B, and WW-5C (see appendix E, fig. E-38 for withdrawal values). 


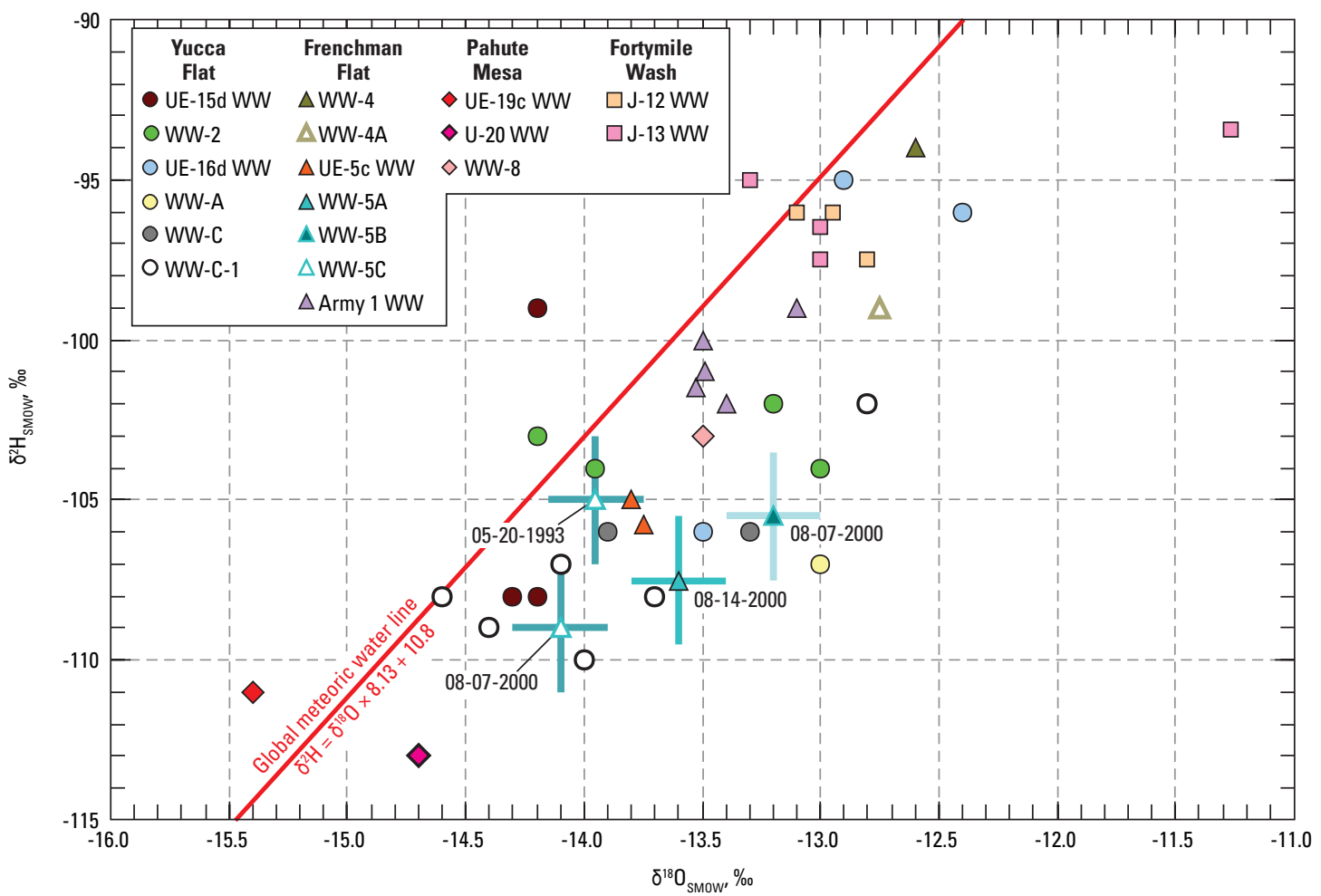

Figure 39. Isotopic compositions of hydrogen and oxygen for water samples from WW-5A, WW-5B, and WW-5C in central Frenchman Flat, and data from other water-supply wells at the Nevada National Security Site, Nye County, Nevada. 


\section{WW-5B}

Borehole Description and Water Withdrawals: WW-5B is in Frenchman Flat in Area 5 of the NNSS, approximately $1.8 \mathrm{mi}$ northwest of WW-5A (fig. 1; table 1). The borehole was drilled to a depth of $900 \mathrm{ft}$ and completed in May 1951. The single completion in the borehole, well $W W-5 B$, is cased to a depth of $900 \mathrm{ft}$ with a slotted interval from 700 to $900 \mathrm{ft}$ (appendix E, fig. E-40). The annular space between the casing and borehole is open from at least $700 \mathrm{ft}$ to the bottom of the casing. The mean water level in the well is at a depth of $686 \mathrm{ft}$ below land surface, which is higher than water levels in WW-5A or WW-5C.

The borehole penetrates alluvium and fine-grained playa sediments from land surface to the bottom of the hole (appendix E, fig. E-40; Wood, 2007). Water is produced from older alluvium classified as part of the alluvial aquifer (Bechtel Nevada, 2005; Fenelon and others, 2010, appendix 3).

WW-5B was constructed as a supply well to provide water for activities in Areas 5, 6, and 23 on the NNSS (fig. 1). Approximately 1,720 Mgal of water have been withdrawn from the well since 1951 (appendix E, fig. E-41A). Pumping ceased for about 4.5 years between October 1988 to May 1993. Pumping was restarted after this interval and has continued to the present (Elliott and Moreo, 2011).

Water Quality: Water from WW-5B has compositions that are distinct from WW-5A, although still characteristic of water from a volcanic aquifer. The water is highly enriched in $\mathrm{Na}$, but Ca constitutes a slightly higher proportion of cations on a trilinear diagram compared to WW-5A water (appendix E, fig. E-42). Bicarbonate is still the dominant anion; however, $\mathrm{SO}_{4}$ and $\mathrm{Cl}$ are more abundant in $\mathrm{WW}-5 \mathrm{~B}$ water relative to WW-5A. These data indicate that although both wells pump water from the alluvial aquifer with volcanic affinities there are distinct differences in composition despite their close proximity (1.8 $\mathrm{mi})$.

Measurements of specific conductance made during periods of pumping (appendix A) show a limited range of values about an overall median value of $501 \mu \mathrm{S} / \mathrm{cm}$ (fig. 40). Although nearly all individual data points are within the expected range of analytical error about the median value, enough measurements were made between 1957 and 2005 to evaluate statistical differences with time. Parametric and nonparametric tests of trend indicate that no statistically significant shifts are present with time (table 14; appendix D-13). However, specific conductance values for samples collected during the first several decades of pumping (1977 and earlier; $\mathrm{N}=15$ ) have a slightly lower mean value of $495.6 \pm 6.0$ (2SE) $\mu \mathrm{S} / \mathrm{cm}$ as compared to samples collected more recently (1988 and later, $\mathrm{N}=23$ ) that have a mean value of $504.7 \pm 5.4 \mu \mathrm{S} / \mathrm{cm}$. Only a few reliable measurements of specific conductance are available for samples collected from the late 1970s to the late 1990s. Although the uncertainties of these two means overlap using the 2SE statistic, a two-sample t-test of the two means indicates that they are distinct at the 95-percent confidence level. A nonparametric Mann-Whitney test of the two data sets yields the same results. In contrast to the shift in WW-5A compositions, these results suggest that water pumped from WW-5B may have become slightly more conductive (higher dissolved ion load) with time. Differences in conductance may be related to differences in overall withdrawal rates in WW-5B between earlier and later withdrawal histories (fig. 40). The mean annual withdrawal from WW-5B between 1951 and 1981 was $23.8 \mathrm{Mgal}$ (median = 22.8) compared to 42.6 Mgal (median = 38.4) for the periods from 1982 to 1988 and 1993 to 2008. Despite this nearly two-fold difference in long term average rates, the overall shift in conductance is subtle and cannot be directly correlated with higher and lower withdrawals during a given year. Data spanning the 4.5 year gap in pumping during the early 1990s are not sufficient to evaluate the effects of this change.

Major ion concentration data are available for samples spanning much of the history of water withdrawals from WW-5B (appendix B). Most elements, with the exception of $\mathrm{SiO}_{2}$, are scattered within or close to the range expected for analytical uncertainty associated with calculated median values and show no obvious evidence for systematic changes over the 49-year period of record (fig. 41). Parametric and nonparametric tests of trend confirm the absence of trends for most constituents (table 14; appendix D-13). The primary exception is $\mathrm{Na}$, which shows a statistically significant trend of decreasing values with time for all tests, even though the total range of variation is close to that expected for analytical error. Mann-Kendall tests indicate slight increases in $\mathrm{Mg}$ and decreases in F with time; however, other tests do not corroborate the statistical significance of shifts in these minor constituents. Concentration data for NA also were separated into similar early and late groupings described previously for specific conductance. Resulting mean Na concentrations from early (1957-1981 = 95.9 \pm 2.2 [2SE] mg/L) and late $(1988-2005=91.6 \pm 1.4$ [2SE] mg/L) samples are clearly distinguished at the 95-percent confidence limit using a two-sample t-test. Nonparametric Mann-Whitney tests of the same data sets yield the same results. No other elements showed similar differences. The small decreases for $\mathrm{Na}$, the dominant cation, do not explain the small increases in conductance. Furthermore, these shifts do not appear to be accompanied by systematic temporal changes in any of the other major anions. 


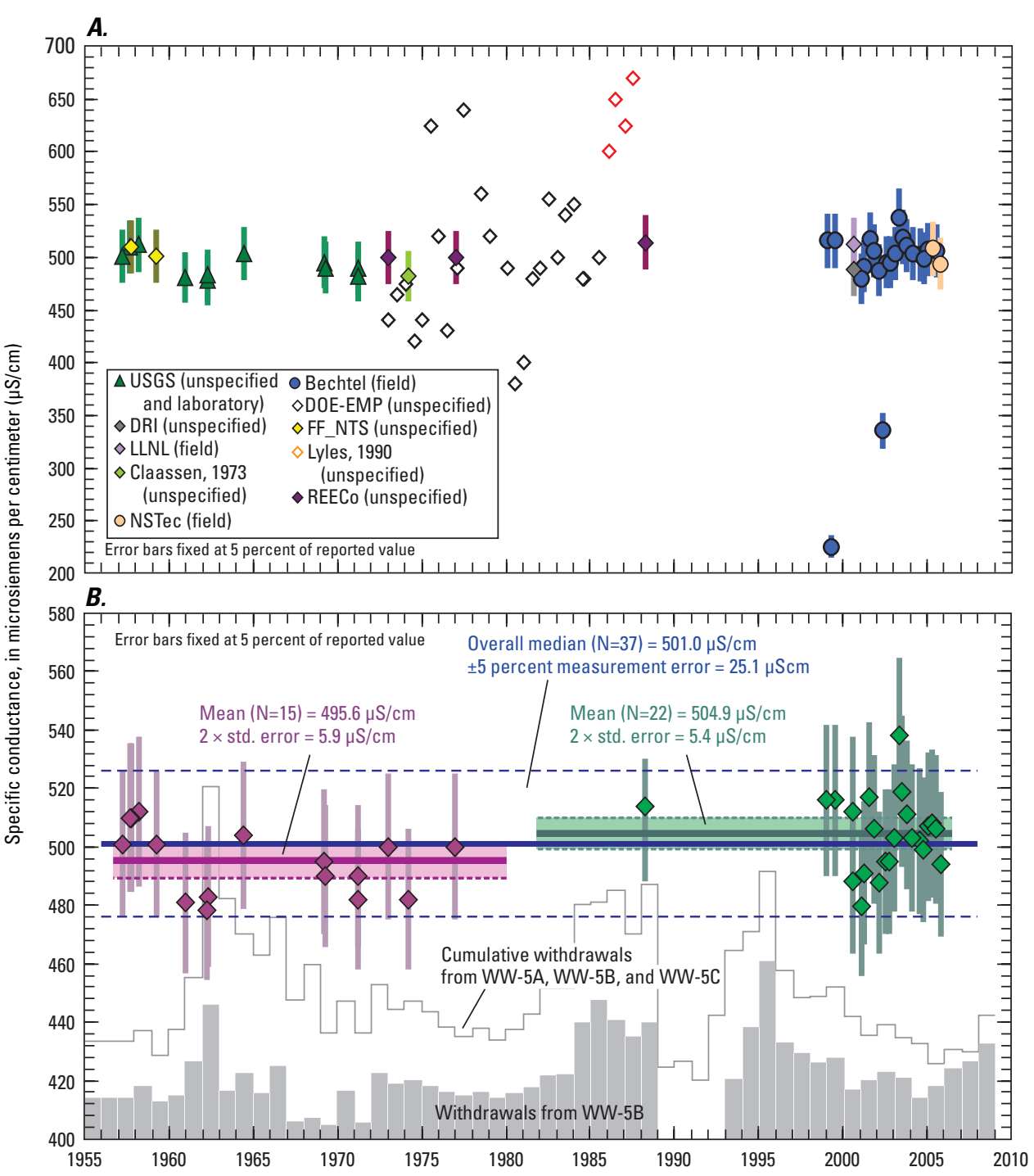

Figure 40. Temporal variations in specific conductance for water samples collected from WW-5B, Nevada National Security Site, Nye County, Nevada. (A) All available specific conductance data from appendix A, identified by source including Bechtel, Bechtel Nevada; Claassen, 1973; DOE-EMP, Department of Energy Environmental Monitoring Program; DRI, Desert Research Institute; FF-NTS database, Frenchman Flat-Nevada Test Site database, data from M. Martin, International Technology (IT) Corporation; LLNL, Lawrence Livermore National Laboratory; Lyles, 1990; NSTec, National Security Technologies, LLC; REECo, Reynolds Electrical \& Engineering Co., Inc.; and USGS, U.S. Geological Survey. Reported measurements were either made in the field, the laboratory, or were unspecified in the database. (B) Specific conductance data used to calculate the median value and trend analysis. Thick, horizontal blue line represents the overall median value, shown along with estimates for 5 percent measurement error (dashed blue lines). Data are further grouped by date (1957-1977 and 1988-2005), and are shown with separate mean and standard deviation values. Shaded histogram represents annual groundwater withdrawals from WW-5B, and the unshaded histogram represents cumulative withdrawals from WW-5A, WW-5B, and WW-5C (see appendix E, fig. E-41 for withdrawal values).

Table 14. Results of trend analyses for major constituents in water pumped from WW-5B, Nevada National Security Site, Nye County, Nevada, between April 4, 1957, and July 25, 2006.

[A bbreviations: MK, Mann-Kendall test; SES, Sen's estimator of slope test; LR, linear regression; -, not applicable]

\begin{tabular}{lcccccc}
\hline \multicolumn{1}{c}{ Constituent } & $\begin{array}{c}\text { Total } \\
\text { samples }\end{array}$ & $\begin{array}{c}\text { Normality } \\
\text { tests }\end{array}$ & $\begin{array}{c}\text { MK } \\
\text { result }\end{array}$ & $\begin{array}{c}\text { SES } \\
\text { result }\end{array}$ & $\begin{array}{c}\text { Residual } \\
\text { normality } \\
\text { test }\end{array}$ & $\begin{array}{c}\text { LR } \\
\text { result }\end{array}$ \\
\hline Conductivity & 37 & passed & no trend & no trend & passed & no trend \\
Calcium $(\mathrm{Ca})$ & 28 & passed & no trend & no trend & passed & no trend \\
Magnesium $(\mathrm{Mg})$ & 28 & failed & increasing & no trend & - & - \\
Sodium $(\mathrm{Na})$ & 27 & passed & decreasing & decreasing & passed & decreasing \\
Potassium $(\mathrm{K})$ & 25 & failed & no trend & no trend & - & - \\
Chloride $(\mathrm{Cl})$ & 28 & passed & no trend & no trend & passed & no trend \\
Bicarbonate $\left(\mathrm{HCO}_{3}\right)$ & 29 & passed & no trend & no trend & passed & no trend \\
Sulfate $\left(\mathrm{SO}_{4}\right)$ & 26 & passed & no trend & no trend & passed & no trend \\
Silicon dioxide $\left(\mathrm{SiO}_{2}\right)$ & 24 & failed & no trend & no trend & - & - \\
Fluoride $(\mathrm{F})$ & 28 & passed & decreasing & no trend & passed & no trend \\
\hline
\end{tabular}



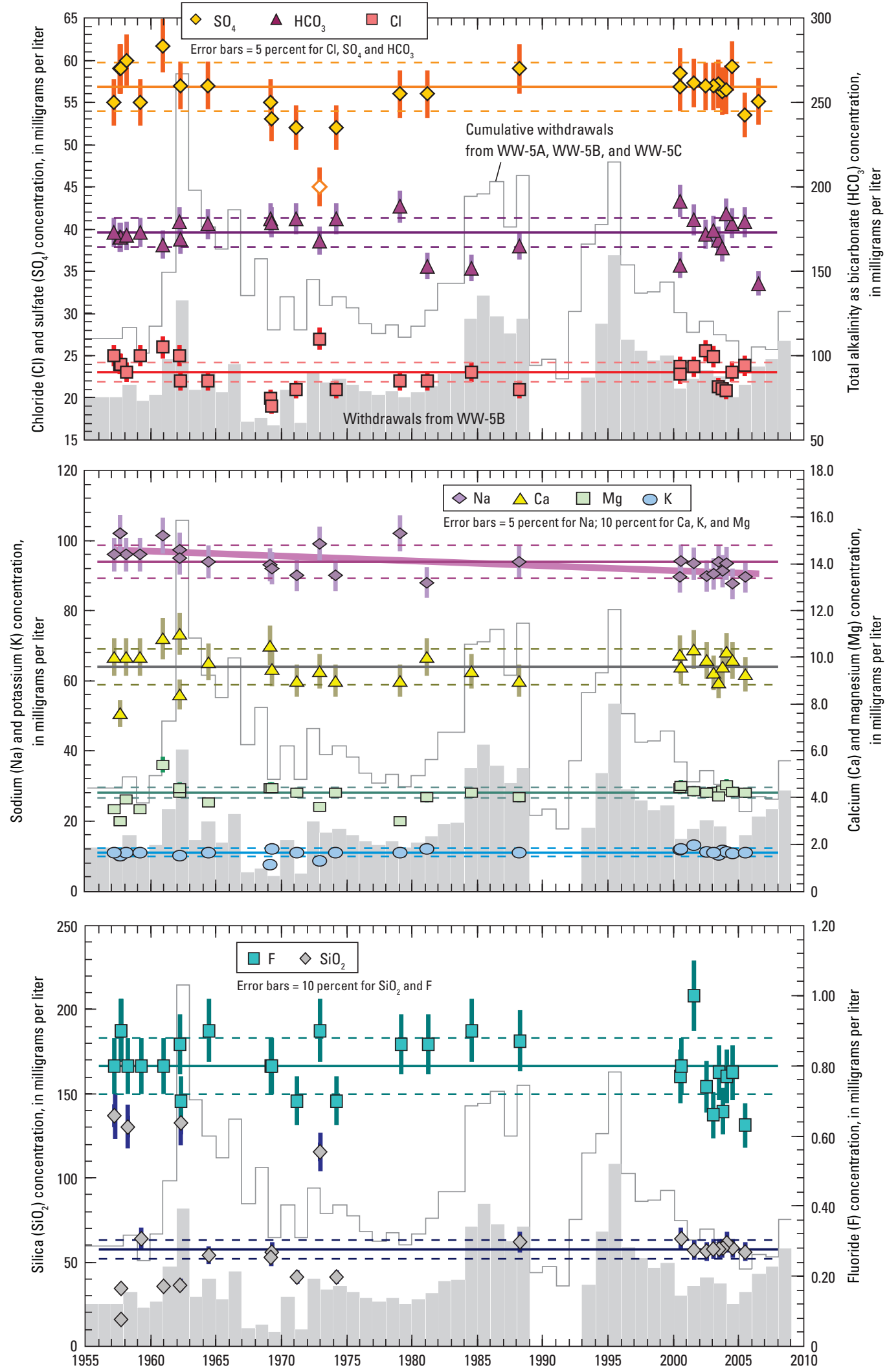

Figure 41. Temporal variations in major-ion concentrations for water samples collected from WW-5B, Nevada National Security Site, Nye County, Nevada. Filled symbols represent data from appendix B used to calculate trend analyses and quantitative statistics (see results in appendix $D$ and appendix $F$, respectively). Open symbols represent outliers and were not included in numerical evaluations. Solid horizontal lines represent median concentration values shown along with estimated measurement error (dashed horizontal lines) using the same values given for error bars on individual analyses. Thick sloping line represents a statistically significant trend in $\mathrm{Na}$. Shaded histogram represents annual groundwater withdrawals from WW-5B, and the unshaded histogram represents cumulative withdrawals from WW-5A, WW-5B, and WW-5C (see appendix E, fig. E-41 for withdrawal values). 
Concentrations of trace elements reported for WW-5B samples span a longer period of record than WW-5A (appendix C), but are no more diagnostic. Most pre-2000 analyses were semiquantitative in nature, or too imprecisely determined to allow evaluation of trends. However, $\mathrm{U}$ concentrations reported for samples collected in the late 1950s and early 1960s are considered reliable, but have larger analytical uncertainties than the post-2000 data. Uranium concentrations range from 4.2 to $6.7 \mu \mathrm{g} / \mathrm{L}$ for five samples collected from 1957 to 1964 . Weighted mean values for these data (5.21 \pm 1.3 [2SE] $\mu \mathrm{g} / \mathrm{L}$ including the 1957 values or $6.18 \pm 0.71$ [2SE] $\mu \mathrm{g} / \mathrm{L}$ excluding the 1957 data) are identical, within analytical uncertainty, of the value of $5.90 \mu \mathrm{g} / \mathrm{L}$ reported for the August 2000 sample (fig. 42). Concentrations of other trace elements, such as As, B, Li, Mo, Sr, V, and
$\mathrm{Zn}$, are available for earlier samples as well as the more quantitative analysis reported for the August 2000 sample; however, data are not sufficiently precise to allow reliable evaluation of temporal trends.

Only one sample from WW-5B collected in August 2000 has been analyzed for $\delta^{2} \mathrm{H}$ and $\delta^{18} \mathrm{O}$ isotopes. Like the sample from WW-5A, water from WW-5B has isotopically "lighter" values than many other NNSS groundwater samples (fig. 39; appendix C). However, $\delta^{2} \mathrm{H}$ and $\delta^{18} \mathrm{O}$ are isotopically "heavier" than WW-5A water, which suggests that WW-5B water has a greater component of young, local recharge. A higher radiocarbon concentration (13.1 percent modern carbon) and a less evolved chemical signature (smaller $\mathrm{Na}$ and $\mathrm{HCO}_{3}$ contents and lower conductance) in samples from WW-5B supports this concept.

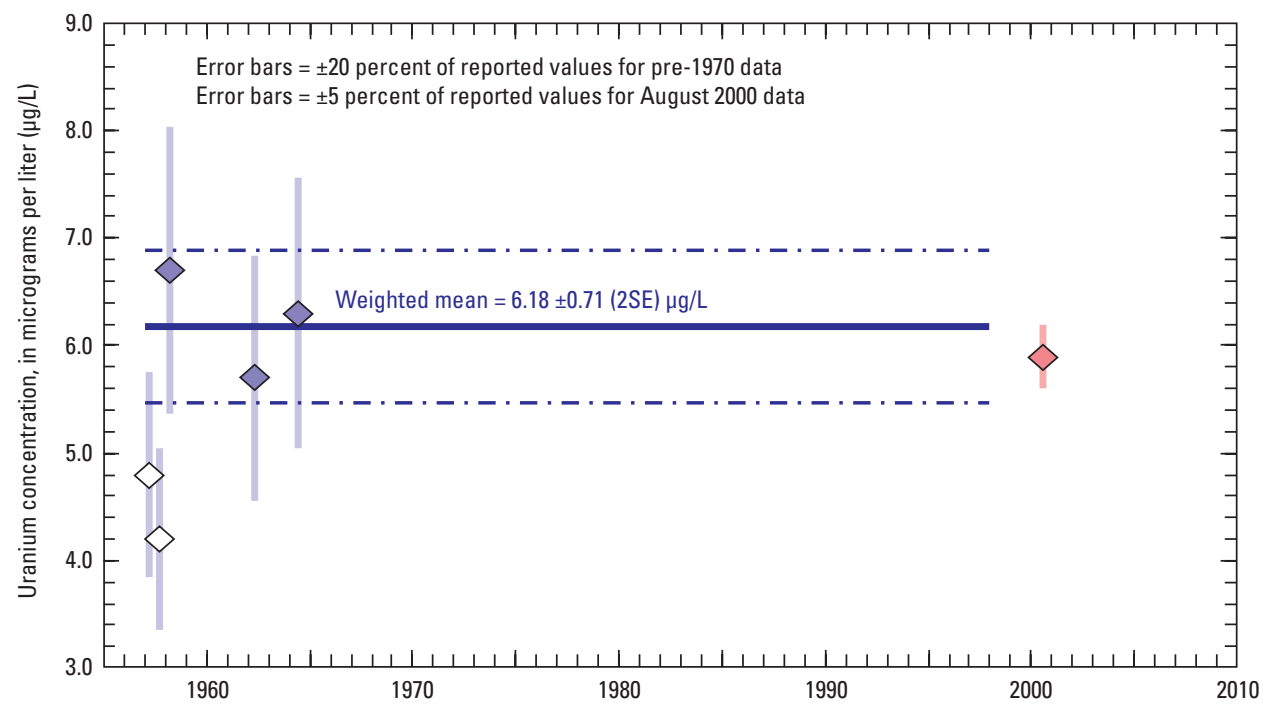

Figure 42. Temporal variations in uranium concentration for water samples collected from WW-5B, Nevada National Security Site, Nye County, Nevada. 


\section{WW-5C}

Borehole Description and Water Withdrawals: WW-5C is in Frenchman Flat in Area 5 of the NNSS, about halfway between WW-5A to the southeast and WW-5B to the northwest (fig. 1; table 1). The borehole was drilled to a depth of 1,200 ft and completed in March 1954. The single completion in the borehole, well $W W-5 C$, is cased to a depth of $1,187 \mathrm{ft}$ and has a slotted interval from 887 to $1,187 \mathrm{ft}$. The annular space between the casing and borehole is open from $20 \mathrm{ft}$ below land surface to the bottom of the hole (appendix E, fig. E-43). The mean water level in the well is at a depth of $702 \mathrm{ft}$ below land surface.

The borehole penetrates alluvium from land surface to the bottom of the hole (appendix E, fig. E-43). Coarse sediment below the water table consists of a mixture of quartzite, limestone, dolomite, and rhyolite in a matrix of sand and lesser clay (Wood, 2007). Water is produced from older alluvium which is considered part of the alluvial aquifer (Bechtel Nevada, 2005; Fenelon and others, 2010, appendix 3).

WW-5C was constructed as a supply well on the NNSS. About 2,010 Mgal of water have been withdrawn from the well since its completion in 1954 (appendix E, fig. E-44A). Although the well was deactivated as a general use supply well in 2005 due to elevated arsenic concentrations (Wills, 2006, p. 4-24), the well continues to provide water for construction activities in Area 5 (U.S. Department of Energy, 2008, table 2-1).
Water Quality: Water from WW-5C has compositions nearly identical to those for WW-5A, discussed previously. Compositions are extremely enriched in $\mathrm{Na}$ and $\mathrm{HCO}_{3}$ and overlap the tight cluster of analyses shown for WW-5A on a trilinear diagram of major ions (appendix E, fig. E-45). Like water from WW-5A, compositions from WW-5C indicate extensive cation-exchange between the groundwater and the zeolitized tuffaceous material present in the alluvial aquifer.

Specific conductance measurements made throughout the period of pumping show limited variations about a median value of $573 \mu \mathrm{S} / \mathrm{cm}$ (fig. 43), which is intermediate between values from WW-5A and WW-5B. However, samples collected prior to 1982 tend to have lower values than samples collected since 1982. Nonparametric tests of trend indicate the presence of a statistically significant shift in conductance with time (table 15; appendix D-14), but the transition between early and late data appears to be abrupt rather than gradual. Separation of the data into early (1957-1981 samples, $\mathrm{N}=14$ ) and late (1982-2005 samples, $\mathrm{N}=28)$ groups results in two means that are statistically resolvable at the 95-percent confidence level (534.8 \pm 10.2 [2SE] and $585.3 \pm 5.2$ [2SE] $\mu \mathrm{S} / \mathrm{cm}$, respectively) using either two-sample t-test or Mann-Whitney criteria. Although the withdrawal history was more uniform at WW-5C compared to WW-5A and WW-5B, the shift in conductance appears to coincide with an increase in cumulative annual pumping that began about 1980 (figs. 43B and appendix E, fig. E-44).

Table 15. Results of trend analyses for major constituents in groundwater pumped from WW-5C, Nevada National Security Site, Nye County, Nevada, between April 1, 1957, and July 25, 2006.

[A bbreviations: MK, Mann-Kendall test; SES, Sen's estimator of slope test; LR, linear regression; -, not applicable]

\begin{tabular}{lcccccc}
\hline \multicolumn{1}{c}{ Constituent } & $\begin{array}{c}\text { Total } \\
\text { samples }\end{array}$ & $\begin{array}{c}\text { Normality } \\
\text { tests }\end{array}$ & $\begin{array}{c}\text { MK } \\
\text { result }\end{array}$ & $\begin{array}{c}\text { SES } \\
\text { result }\end{array}$ & $\begin{array}{c}\text { Residual } \\
\text { normality } \\
\text { test }\end{array}$ & $\begin{array}{c}\text { LR } \\
\text { result }\end{array}$ \\
\hline Conductivity & 43 & failed & increasing & increasing & - & - \\
Calcium $(\mathrm{Ca})$ & 26 & failed & no trend & no trend & - & - \\
Magnesium $(\mathrm{Mg})$ & 27 & failed & no trend & no trend & - & - \\
Sodium $(\mathrm{Na})$ & 29 & passed & increasing & increasing & passed & increasing \\
Potassium $(\mathrm{K})$ & 28 & passed & no trend & no trend & failed & - \\
Chloride $(\mathrm{Cl})$ & 32 & failed & no trend & no trend & - & - \\
Bicarbonate $\left(\mathrm{HCO}_{3}\right)$ & 32 & passed & no trend & no trend & passed & no trend \\
Sulfate $\left(\mathrm{SO}_{4}\right)$ & 30 & passed & increasing & increasing & passed & increasing \\
Silicon dioxide $\left(\mathrm{SiO}_{2}\right)$ & 23 & passed & no trend & no trend & passed & no trend \\
Fluoride $(\mathrm{F})$ & 30 & passed & increasing & increasing & passed & increasing \\
\hline
\end{tabular}




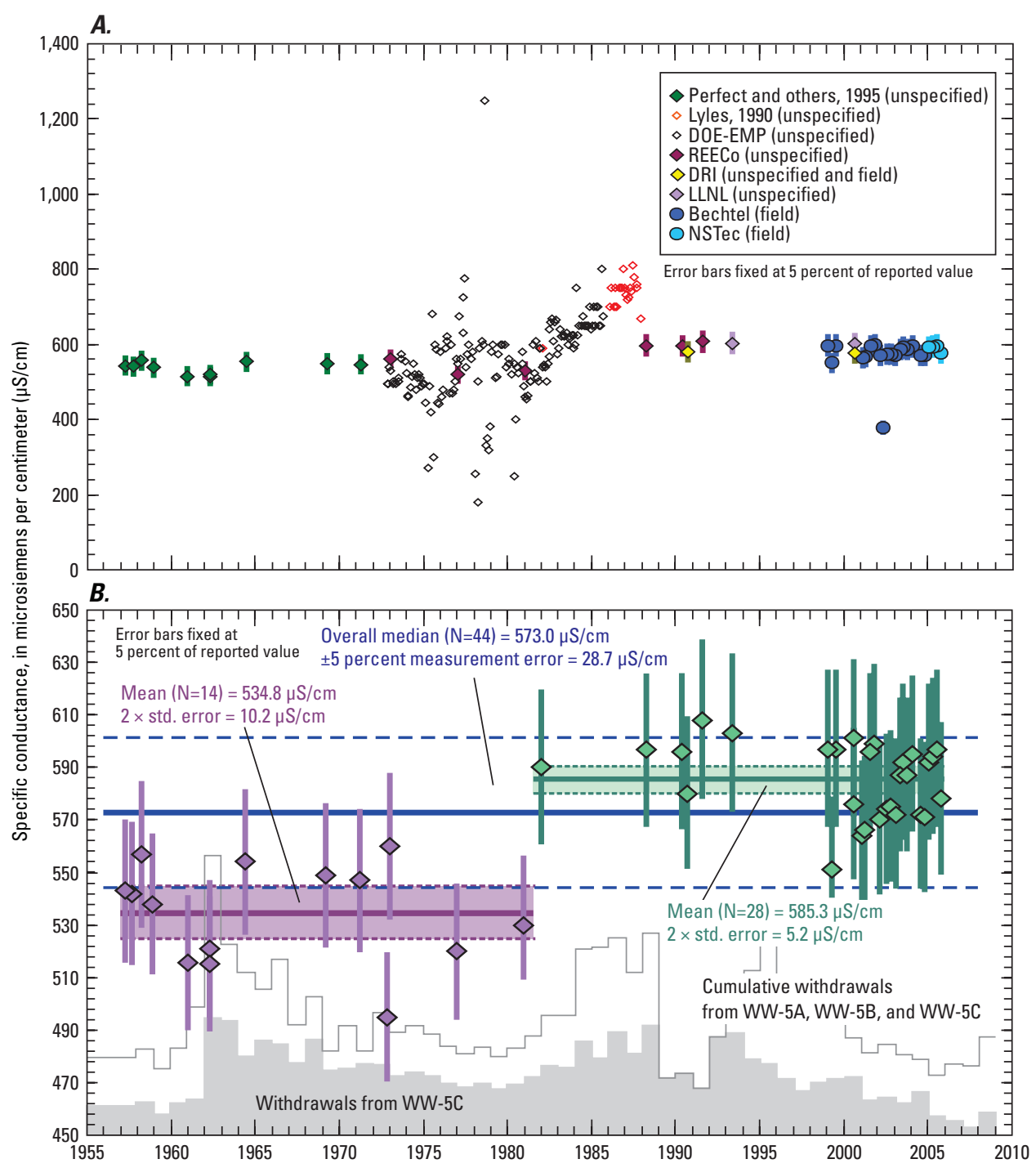

Figure 43. Temporal variations in specific conductance for water samples collected from WW-5C, Nevada National Security Site, Nye County, Nevada. (A) All available specific conductance data from appendix A, identified by source including Bechtel, Bechtel Nevada; DOE-EMP, Department of Energy Environmental Monitoring Program; DRI, Desert Research Institute; LLNL, Lawrence Livermore National Laboratory; Lyles, 1990; NSTec, National Security Technologies, LLC; Perfect and others, 1995; and REECo, Reynolds Electrical \& Engineering Co., Inc. Reported measurements were either made in the field, the laboratory, or were unspecified in the database. $(B)$ Specific conductance data used to calculate the median value and trend analysis. Thick, horizontal blue line represents the overall median value shown along with estimates for 5 percent measurement error (dashed blue lines). Data are further grouped by date (1957-1981 and 1988-2005), and are shown with separate mean and standard deviation values. Shaded histogram represents annual groundwater withdrawals from WW-5C, and the unshaded histogram represents cumulative withdrawals from WW-5A, WW-5B, and WW-5C (see appendix E, fig. E-44 for withdrawal values). 
Major ion concentrations in samples, which span most of the period of pumping, scatter beyond the range expected for analytical errors about their median values (fig. 44; appendix B). All parametric and nonparametric tests of trend indicate small, but significant increases in $\mathrm{Na}, \mathrm{SO}_{4}$, and $\mathrm{F}$ concentrations over the period of record (appendix D-14). These shifts in concentration seem more transitional than the apparent step-change in conductance. Early samples grouped similarly to conductance have mean $\mathrm{Na}, \mathrm{SO}_{4}$, and F values of $129.4 \pm 2.0( \pm 2 \mathrm{SE}) \mathrm{mg} / \mathrm{L}, 24.85 \pm 0.78 \mathrm{mg} / \mathrm{L}$, and $0.767 \pm 0.062 \mathrm{mg} / \mathrm{L}$, respectively, whereas late samples have mean values of $132.3 \pm 1.8 \mathrm{mg} / \mathrm{L}, 29.06 \pm 0.70$, and $0.973 \pm 0.042 \mathrm{mg} / \mathrm{L}$, respectively.

Other major ion constituents do not show monotonic changes in composition with time. However, $\mathrm{HCO}_{3}$ and, to a lesser extent, $\mathrm{Cl}$ concentrations show fluctuations that may be related to pumping history. Parametric and nonparametric tests indicate that the means for early and late groupings of $\mathrm{HCO}_{3}$ are distinct at high levels of significance (greater than 99 percent confidence levels). Interestingly, the pattern of $\mathrm{HCO}_{3}$ variations visually mimics the histogram of annual water withdrawals (fig. 44), with higher $\mathrm{HCO}_{3}$ concentrations corresponding to periods of higher withdrawals. Attempts to establish a numerical correlation between individual measurements of $\mathrm{HCO}_{3}$ concentration and annual water withdrawals have not been successful (fig. 45A). There is some visual indication that $\mathrm{Cl}$ concentrations are negatively correlated with pumping and $\mathrm{HCO}_{3}$ concentrations (fig. 45B). Relations between $\mathrm{Cl}$ and $\mathrm{HCO}_{3}$ indicate that this may be true for early samples (assuming there is a relation between $\mathrm{HCO}_{3}$ and pumping), but the same relation is not observed for later samples (fig. 45B). Other constituents do not show similar shorter-term cycles of variation in concentration.

The lack of reliable, quantitative, trace element analyses of water samples collected from WW-5C limits their use in evaluating temporal trends. Uranium concentrations reported for samples collected from 1958 to 1993 range from 5.6 to $6.7 \mu \mathrm{g} / \mathrm{L}$, with a weighted mean value (weighting based on errors, that is, inverse variances, assigned to data points; Ludwig, 2003) of $6.31 \pm 0.48$ (2SE) $\mu$ g/L (fig. 46A). The weighted mean value measured from the August 2000 sample of $7.59 \pm 0.19 \mu \mathrm{g} / \mathrm{L}$ is outside the $2 \mathrm{SE}$ uncertainty range for the mean of the earlier samples, and represents a 20 percent increase from the value for earlier samples. The higher As value reported for the August 2000 sample $(36.9 \mu \mathrm{g} / \mathrm{L})$ represents a similar increase in concentration (approximately 15 percent) relative to the mean value of $32 \mu \mathrm{g} / \mathrm{L}$ obtained for samples collected from 1988 to 1993, although similarly high As values were reported for samples collected from 1973 to 1981 (fig. 46B). Other trace elements were not determined precisely enough to allow for reliable comparisons.

Isotopic compositions of $\mathrm{H}$ and $\mathrm{O}$ were determined from WW-5C samples collected in 1993 and 2000 (fig. 39; appendix C). Both samples have analytically identical $\delta^{18} \mathrm{O}$ values of -14.0 and $-14.1 \%$, but $\delta^{2} \mathrm{H}$ values of -105 and $-109 \%$, which are at the limit of overlapping errors. It is not clear if these differences in $\delta^{2} \mathrm{H}$ represent a real compositional change from 1993 to 2000, or an analytical artifact. Regardless of the $\delta^{2} \mathrm{H}$ discrepancy, $\delta^{18} \mathrm{O}$ data are similar to, or slightly lighter than, the value reported for WW-5A. Low radiocarbon concentrations (3.13 and 3.4 percent modern carbon for 1993 and 2000 samples, respectively; appendix C) are analytically identical to the value of 2.6 percent modern carbon reported for WW-5A. Additionally, $\delta^{13} \mathrm{C}$ and ${ }^{87} \mathrm{Sr} /{ }^{86} \mathrm{Sr}$ isotopic results reported for the 1993 and 2000 samples collected from WW-5C also are analytically identical (appendix C). The similarities of $\mathrm{O}, \mathrm{Sr}$, and $\mathrm{C}$ isotopic compositions, as well as ${ }^{14} \mathrm{C}$ concentrations for the 1993 and 2000 samples from WW-5C strongly suggest that the difference between reported $\delta^{2} \mathrm{H}$ values is more likely the result of spurious analytical data rather than real differences in $\delta^{2} \mathrm{H}$ with time.

Close similarities in radiocarbon content, stable-isotope composition, major ion chemistry and most trace element concentrations in water samples from WW-5A and WW-5C indicate that water in these wells share a closely related source within the alluvial aquifer (table 16). Water from WW-5B has compositions that are more distinct than samples from WW-5A and WW-5C. These differences indicate that WW-5B water has a distinct source within the alluvial aquifer despite its close lateral proximity to the other two wells to the southeast. Furthermore, the small temporal shifts in composition in all three wells may be related to the pumping history and hydrologic properties of discrete units within the alluvium. Data compiled in table 16 for samples collected from all three wells in August 2000 indicate that values for a number of constituents in the spatially intermediate well, WW-5C, are numerically intermediate between values reported for the other two wells. However, this is not the case for all constituents. As a result, simple two-component mixing involving pumping-induced gradients with endmember compositions derived from WW-5A and WW-5B is not capable of explaining the composition present in WW-5C. A more detailed evaluation of this interaction is beyond the scope of this report. 

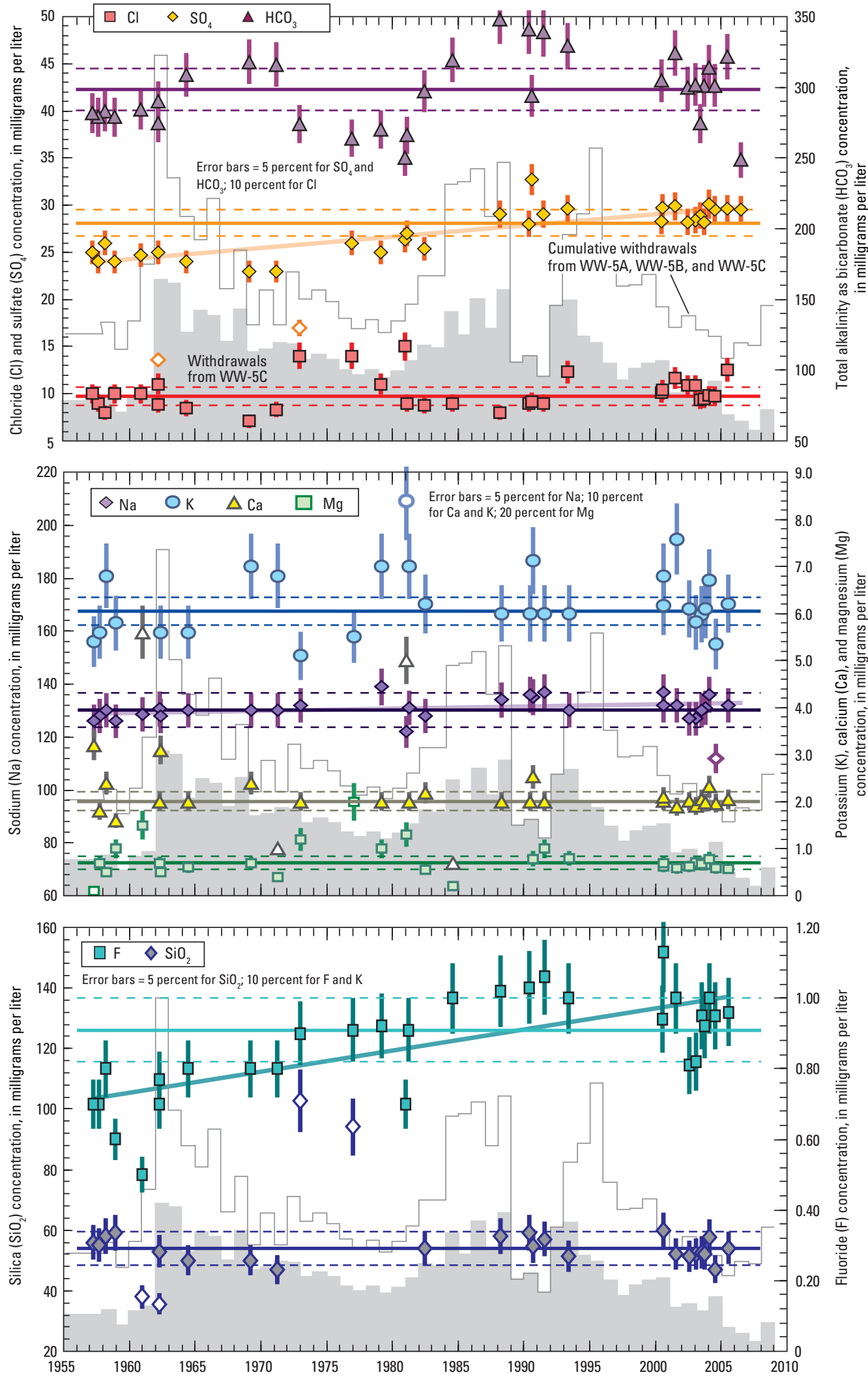

Figure 44. Temporal variations in major-ion concentrations for water samples collected from WW-5C, Nevada National Security Site, Nye County, Nevada. Filled symbols represent data from appendix B used to calculate trend analyses and quantitative statistics (see results in appendix $\mathrm{D}$ and appendix $\mathrm{F}$, respectively). Open symbols represent outliers and were not included in numerical evaluations. Solid horizontal lines represent median concentration values shown along with estimated measurement error (dashed horizontal lines) using the same values given for error bars on individual analyses. Thick sloping lines represent statistically significant trends. Shaded histogram represents annual groundwater withdrawals from WW-5C, and the unshaded histogram represents cumulative withdrawals from WW-5A, WW-5B, and WW-5C (see appendix E, fig. E-44 for withdrawal values). 

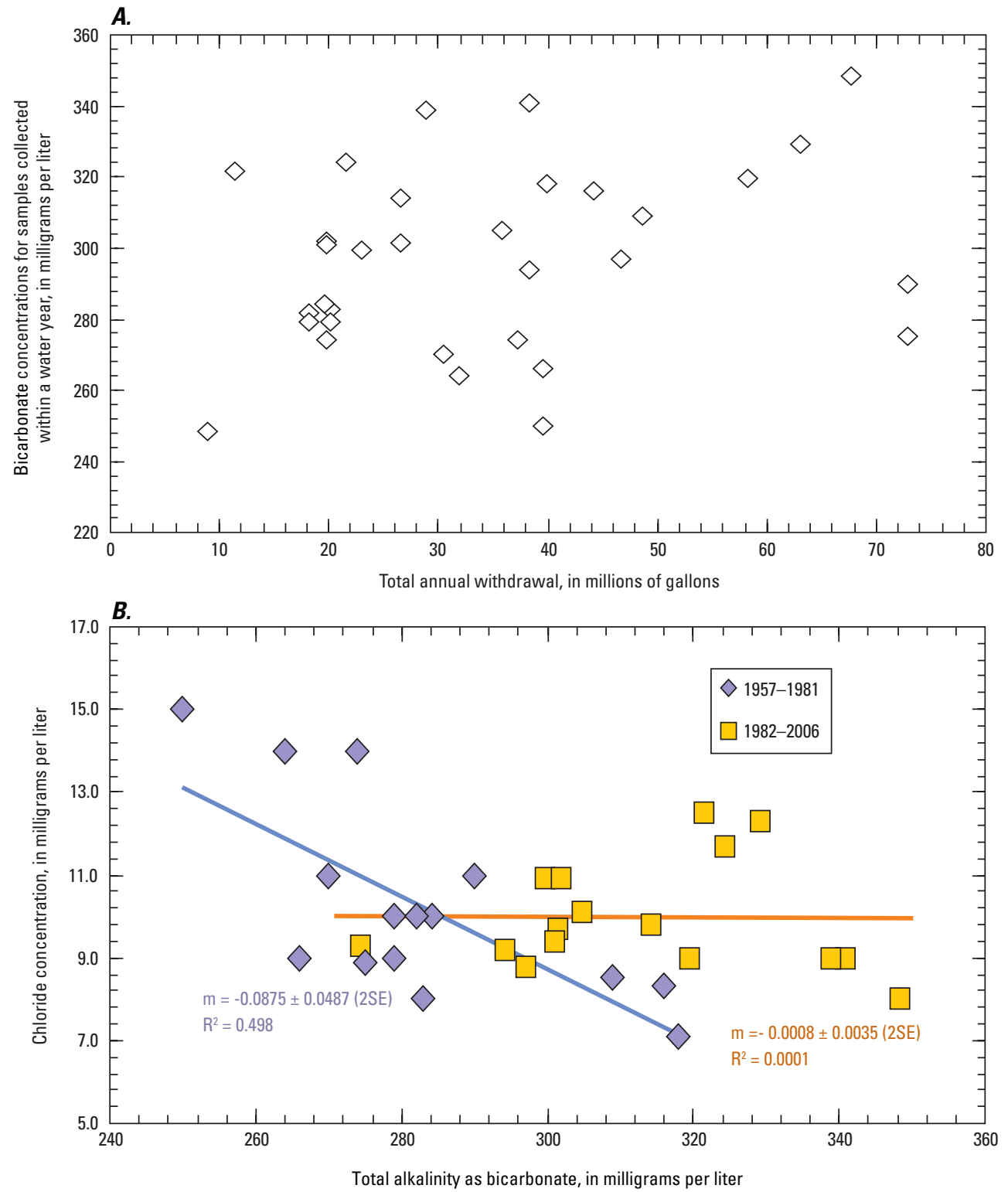

Figure 45. Relations between $(A)$ total annual water withdrawn from WW-5C and bicarbonate $\left(\mathrm{HCO}_{3}\right)$ concentrations for samples collected within a given water year, and $(B)$ chloride and total alkalinity as $\mathrm{HCO}_{3}$ for water samples collected from WW-5C, Nevada National Security Site, Nye County, Nevada. Slope ( $m$; with two-times standard error, 2SE) and coefficient of determination $\left(R^{2}\right)$ values are given for linear regression results in $(B)$. 

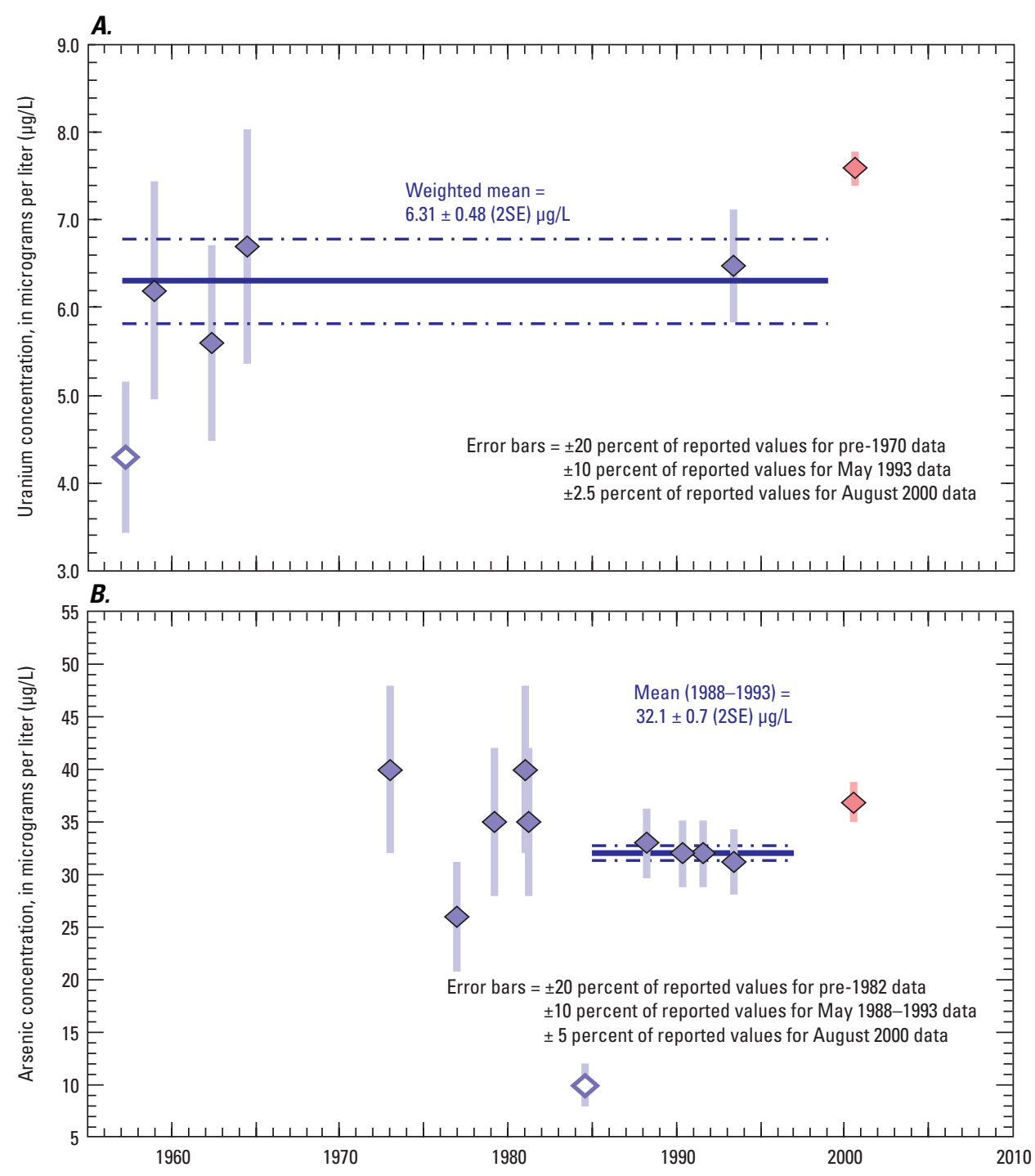

Figure 46. Temporal variations in $(A)$ uranium and $(B)$ arsenic concentrations for water samples collected from WW-5C, Nevada National Security Site, Nye County, Nevada. 
Table 16. Comparison of chemical and isotopic data from water samples collected in August 2000 from WW-5A, WW-5C, and WW-5B, Nevada National Security Site, Nye County, Nevada.

[A bbreviations: AR, activity ratio; $\mu \mathrm{S} / \mathrm{cm}$, microsiemens per centimeter; $\mathrm{mg} / \mathrm{L}$, milligram per liter; $\mu \mathrm{g} / \mathrm{L}$ microgram per liter; \%o, per mil; pmc, percent modern carbon; USGS, U.S. Geological Survey; <, less than; -, no data]

\begin{tabular}{|c|c|c|c|}
\hline USGS borehole name & WW-5A & WW-5C & WW-5B \\
\hline $\begin{array}{l}\text { Spatial location } \\
\text { within linear well array }\end{array}$ & $\begin{array}{c}\text { Southeastern- } \\
\text { most }\end{array}$ & Intermediate & $\begin{array}{l}\text { Northwestern- } \\
\text { most }\end{array}$ \\
\hline Sample collection date & 08-14-2000 & 08-07-2000 & 08-07-2000 \\
\hline Specific conductivity, $\mu \mathrm{S} / \mathrm{cm}$ & 585 & 589 & 500 \\
\hline Sodium, (Na), mg/L & 141.5 & 137 & 94.1 \\
\hline Potassium (K), mg/L & 5.50 & 6.80 & 12.00 \\
\hline Calcium (Ca), mg/L & 2.1 & 2.1 & 7.6 \\
\hline Magnesium (Mg), mg/L & .9 & .7 & 2.5 \\
\hline Silica $\left(\mathrm{SiO}_{2}\right), \mathrm{mg} / \mathrm{L}$ & 45.7 & 59.8 & 63.9 \\
\hline Bicarbonate $\left(\mathrm{HCO}_{3}\right), \mathrm{mg} / \mathrm{L}$ & 309 & - & 192 \\
\hline Chloride (Cl), mg/L & 10.6 & 10.4 & 22.8 \\
\hline Sulfate $\left(\mathrm{SO}_{4}\right), \mathrm{mg} / \mathrm{L}$ & 28.4 & 29.7 & 58.5 \\
\hline Fluoride $(\mathrm{F}), \mathrm{mg} / \mathrm{L}$ & 1.14 & 1.13 & .80 \\
\hline Arsenic (As), $\mu \mathrm{g} / \mathrm{L}$ & 26.4 & 36.9 & 9.81 \\
\hline Barium (Ba), $\mu \mathrm{g} / \mathrm{L}$ & 1.36 & 1.49 & - \\
\hline Beryllium (Be), $\mu \mathrm{g} / \mathrm{L}$ & $<.018$ & $<.018$ & $<.018$ \\
\hline Cadmium (Cd), $\mu \mathrm{g} / \mathrm{L}$ & .008 & .010 & $<.008$ \\
\hline Colbalt (Co), $\mu \mathrm{g} / \mathrm{L}$ & .018 & 6 & .009 \\
\hline Chromium (Cr), $\mu \mathrm{g} / \mathrm{L}$ & 1.32 & 2.63 & 4.59 \\
\hline $\operatorname{Iron}(\mathrm{Fe}), \mu \mathrm{g} / \mathrm{L}$ & 7.9 & 10.2 & 24.2 \\
\hline Mercury (Hg), $\mu \mathrm{g} / \mathrm{L}$ & 21.9 & - & - \\
\hline Lithium (Li), $\mu \mathrm{g} / \mathrm{L}$ & - & 8.49 & 46.9 \\
\hline Manganese (Mn), $\mu \mathrm{g} / \mathrm{L}$ & 1.54 & .27 & 1.06 \\
\hline Molybdenum (Mo), $\mu \mathrm{g} / \mathrm{L}$ & 7.75 & 6.68 & 3.46 \\
\hline Nickel (Ni), $\mu \mathrm{g} / \mathrm{L}$ & .21 & 35 & .18 \\
\hline Lead $(\mathrm{Pb}), \mu \mathrm{g} / \mathrm{L}$ & .05 & .55 & .73 \\
\hline Rubidium (Rb), $\mu \mathrm{g} / \mathrm{L}$ & 4.13 & 5.72 & 9.45 \\
\hline Antimony (Sb), $\mu \mathrm{g} / \mathrm{L}$ & .69 & .90 & .25 \\
\hline Selenium (Se), $\mu \mathrm{g} / \mathrm{L}$ & 1.34 & .90 & 1.76 \\
\hline Strontium (Sr), $\mu \mathrm{g} / \mathrm{L}$ & 24.4 & 21.7 & 27.55 \\
\hline Uranium (U), $\mu \mathrm{g} / \mathrm{L}$ & 7.06 & 7.59 & 5.90 \\
\hline Vanadium $(\mathrm{V}), \mu \mathrm{g} / \mathrm{L}$ & 18.6 & 23.2 & 9.69 \\
\hline Zinc (Zn), $\mu g / L$ & 1.36 & 2.21 & 2.82 \\
\hline$\delta^{2} \mathrm{H}, \%$ & -107.5 & -109 & -105.5 \\
\hline$\delta^{18} \mathrm{O}, \%$ & -13.6 & -14.1 & -13.2 \\
\hline$\delta^{13} \mathrm{C}, \%$ & -4.55 & -6.05 & -9.75 \\
\hline${ }^{14} \mathrm{C}, \mathrm{pmc}$ & 2.6 & 3.4 & 13.1 \\
\hline${ }^{36} \mathrm{Cl} / \mathrm{Cl} \times 10^{-13}$ & 8.43 & - & 7.83 \\
\hline${ }^{87} \mathrm{Sr} /{ }^{86} \mathrm{Sr}$ & .71037 & .71067 & .71042 \\
\hline${ }^{234} \mathrm{U} /{ }^{238} \mathrm{U}$ AR & 2.16 & 1.945 & 1.451 \\
\hline
\end{tabular}




\section{WW-8}

Borehole Description and Water Withdrawals: WW-8 is southeast of Pahute Mesa in Area 18 of the NNSS (fig. 1; table 1). The borehole was drilled to a depth of 5,490 ft in December 1962 and completed as a supply well in January 1963. Borehole WW-8 has had two completion intervals during its withdrawal history (Elliott and Moreo, 2011). Well WW-8 (2031-5490 ft) consisted of casing to a depth of 2,936 ft and an open borehole below the casing. The annular space between the casing and borehole was open from 2,031 to $2,936 \mathrm{ft}$. The casing was slotted from 2,038 to $2,070 \mathrm{ft}$ and 2,137 to 2,170 ft. Subsequently, well $W W-8(30-2031 \mathrm{ft})$ was completed on January 7, 1963, after a bridge plug was installed at a depth of 1,862 ft, sealing off the lower part of the hole. The casing is perforated above the bridge plug from 1,250 to $1,300 \mathrm{ft}, 1,450$ to $1,500 \mathrm{ft}$, and 1,630 to $1,780 \mathrm{ft}$ with an open annular space from 30 to 2,031 ft (appendix E, fig. E-46). The mean water level in the final completion, well $W W-8$ (30-2031 ft), is at a depth of 1,076 ft below land surface.

The borehole penetrates alluvium from 0 to $15 \mathrm{ft}$, and alternating layers of welded and nonwelded tuffs from 15 to $5,490 \mathrm{ft}$; the tuffs are interbedded with lava flows from 792 to $1,128 \mathrm{ft}, 1,276$ to $1,642 \mathrm{ft}$, and 1,689 to $2,010 \mathrm{ft}$ (appendix E, fig. E-46; Warren and others, 2003; Wood, 2007). Water production is primarily from rhyolitic lava flows and interbedded welded tuffs present from 1,290 to 2,010 ft (L.R. West and William Thordarson, U.S. Geological Survey, written commun., 1963, p. 3-4; Gillespie and others, 1996, p. 37). These units are included in the Belted Range aquifer (National Security Technologies, LLC, 2007; Fenelon and others, 2010, appendix 3). Nearly all the water produced from this well and all of the chemical analyses reported here are from the final completion, hereafter referred to as WW-8.

WW-8 was drilled as an exploratory hole, and was later used to supply water for activities in Area 12 of the NNSS (Thordarson and others, 1967, p. 18; Russell, 1989, p. 31; Elliott and Moreo, 2011). About 1,800 Mgal of water have been pumped from the well since 1963 (appendix E, fig. E-47). Approximately 90 percent of the water was produced prior to 1996; however, pumping has continued through the present.

Water Quality: Water pumped from WW-8 is dominated by $\mathrm{Na}$ and $\mathrm{HCO}_{3}$, typical of water derived from volcanic aquifers (appendix B). Most analyses plot in a tight cluster on a trilinear diagram of major ions, indicating a limited range of compositional variation over the 43-year period of record (appendix E, fig. E-48). Calcium constitutes more than 20 percent of the cation load, indicating that the volcanic rocks constituting the aquifer are not dominated by zeolitized tuffs. Both $\mathrm{SO}_{4}$ and $\mathrm{Cl}$ are present in small, subequal proportions.

Specific conductance measured during the period of pumping shows limited variations about a median value of $197 \mu \mathrm{S} / \mathrm{cm}$ (fig. 47). This value is lower than values for groundwater from most NNSS wells, and implies relatively short flow paths from recharge areas and only limited opportunity for water-rock interaction. Data are scattered evenly about the median with no visual or statistical evidence of systematic changes in composition with time (table 17; appendix D-15). These results indicate that the dissolved ion load in water produced from WW-8 likely has remained constant despite the large change (more than a factor of 2) from higher pumping rates before 1995 to lower rates after 1995 (figs. 47 and appendix E, fig. E-47).

Table 17. Results of trend analyses for major constituents in water pumped from WW-8, Nevada National Security Site, Nye County, Nevada, between January 11, 1963, and July 25, 2006.

[Abbreviations: MK, Mann-Kendall test; SES, Sen's estimator of slope test; LR, linear regression; -, not applicable]

\begin{tabular}{lclcccc}
\hline \multicolumn{1}{c}{ Constituent } & $\begin{array}{c}\text { Total } \\
\text { samples }\end{array}$ & $\begin{array}{c}\text { Normality } \\
\text { tests }\end{array}$ & $\begin{array}{c}\text { MK } \\
\text { result }\end{array}$ & $\begin{array}{c}\text { SES } \\
\text { result }\end{array}$ & $\begin{array}{c}\text { Residual } \\
\text { normality } \\
\text { test }\end{array}$ & $\begin{array}{c}\text { LR } \\
\text { result }\end{array}$ \\
\hline Conductivity & 29 & passed & no trend & no trend & passed & no trend \\
Calcium $(\mathrm{Ca})$ & 27 & failed & no trend & no trend & - & - \\
Magnesium $(\mathrm{Mg})$ & 26 & failed & no trend & no trend & - & - \\
Sodium $(\mathrm{Na})$ & 23 & passed & no trend & no trend & passed & no trend \\
Potassium $(\mathrm{K})$ & 24 & inconclusive & no trend & no trend & passed & no trend \\
Chloride $(\mathrm{Cl})$ & 26 & passed & no trend & no trend & passed & no trend \\
Bicarbonate $\left(\mathrm{HCO}_{3}\right)$ & 26 & failed & no trend & no trend & - & - \\
Sulfate $\left(\mathrm{SO}_{4}\right)$ & 25 & failed & no trend & no trend & - & - \\
Silicon dioxide $\left(\mathrm{SiO}_{2}\right)$ & 23 & passed & no trend & no trend & passed & no trend \\
Fluoride $(\mathrm{F})$ & 20 & passed & no trend & no trend & passed & no trend \\
\hline
\end{tabular}




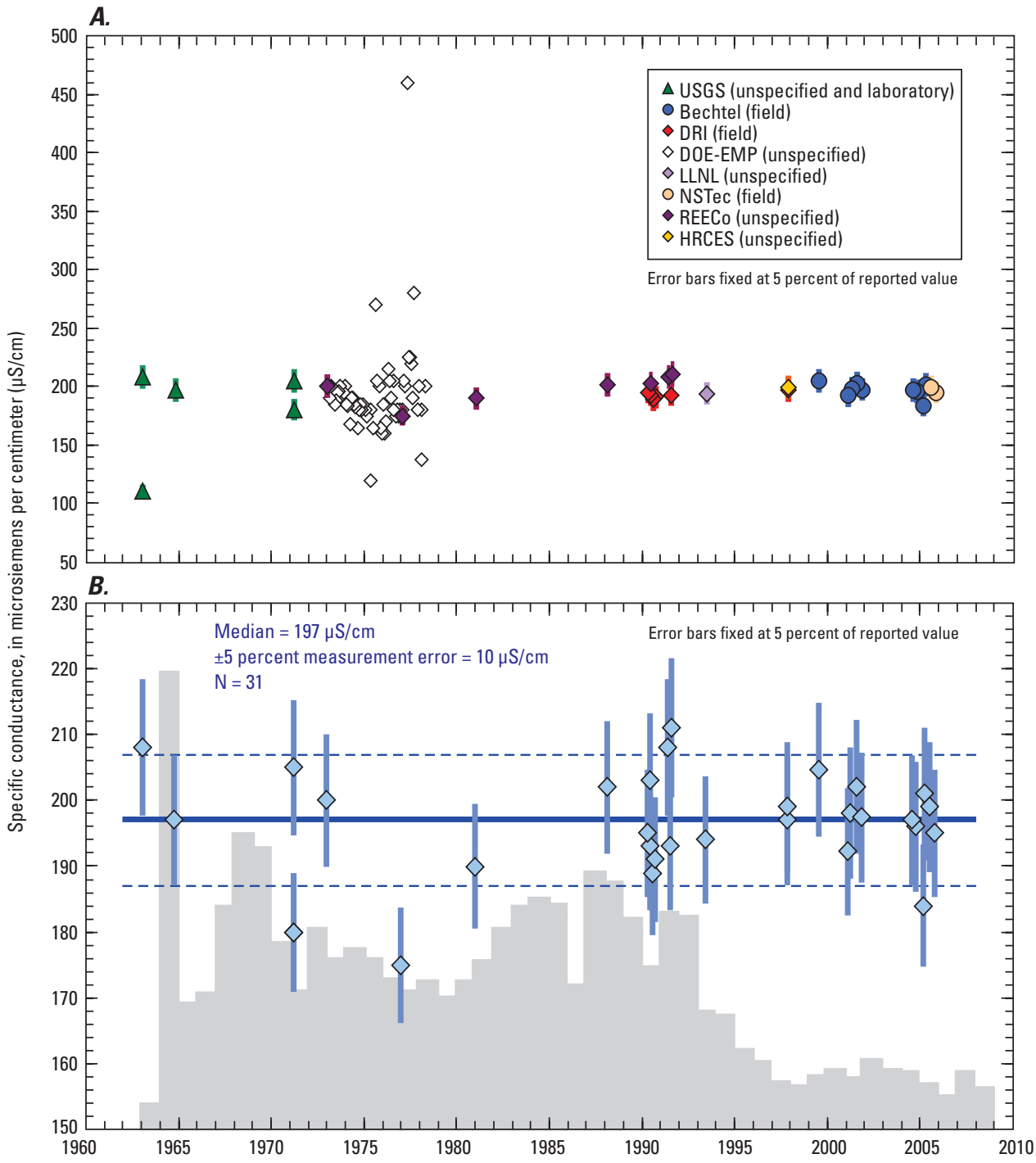

Figure 47. Temporal variations in specific conductance for water samples collected from WW-8, Nevada National Security Site, Nye County, Nevada. (A) All available specific conductance data from appendix A, identified by source including Bechtel, Bechtel Nevada; DOE-EMP, Department of Energy Environmental Monitoring Program; DRI, Desert Research Institute; HRCES, Harry Reid Center for Environmental Studies; LLNL, Lawrence Livermore National Laboratory; NSTec, National Security Technologies, LLC; REECo, Reynolds Electrical \& Engineering Co., Inc, and USGS, U.S. Geological Survey. Reported measurements were either made in the field, the laboratory, or were unspecified in the database. $(B)$ Specific conductance data used to calculate the median value and trend analysis. Thick, horizontal blue line represents the median value shown along with estimates for 5 percent measurement error (dashed blue lines). Shaded histogram represents annual groundwater withdrawals from WW-8 (see appendix E, fig. E-47 for withdrawal values). 
Major ion concentrations in water sampled from WW-8 (appendix B) commonly scatter beyond the range expected for analytical errors about the median values (fig. 48). However, parametric and nonparametric tests of trend show no evidence for significant systematic changes in concentration with time (table 17; appendix D-15). As a further test for the possible presence of chemical shifts related to the distinct change in withdrawal history, statistical comparisons of the data were made using two-sample t-tests and Mann-Whitney tests on pre- and post-1995 groupings of the data. Results indicate that there is no evidence to support a difference in composition between these two groups except for F. Although several constituents scatter beyond expected analytical uncertainties from median values (for example, $\mathrm{Cl}$ ), there is no visual indication that fluctuations are correlated with variations in pumping rates (fig. 48). Collectively, these data are interpreted as an indication that WW-8 water compositions have remained uniform during the more than 40 years of pumping.

$\mathrm{Li}$ and $\mathrm{U}$ are the only reliable trace elements reported since pumping began in WW-8 (appendix C). Concentrations of Li range from 10 to $40 \mu \mathrm{g} / \mathrm{L}$ for analyses reported from the 1960s and 1970s, and from 20 to $28 \mu \mathrm{g} / \mathrm{L}$ for analyses reported from the 1990s to present (excluding one spurious value of less than $10 \mu \mathrm{g} / \mathrm{L}$ ). Mean values for earlier and later analyses are statistically distinct (fig. 49); however, interpreting this result as significant is problematic, considering the uncertainties in data quality from different laboratories at different times. Concentrations of $\mathrm{U}$ range from 0.4 to $0.8 \mu \mathrm{g} / \mathrm{L}$ for three analyses reported for samples collected in the $1960 \mathrm{~s}$ and from 0.37 to $0.6 \mu \mathrm{g} / \mathrm{L}$ for two analyses reported for samples collected in the 1990s (fig. 49). Given the low concentrations, the relatively large uncertainties likely for older analyses, and the small number of analyses, these results are interpreted as an indication that $\mathrm{U}$ concentrations did not change significantly between earlier and later samples.

Isotopic compositions of $\mathrm{H}$ and $\mathrm{O}$ have been determined for only one water sample collected in 1997 from WW-8 (appendix C). Results are plotted with samples from Pahute Mesa (fig. 14). The isotopic composition of WW-8 water is isotopically "heavier" than samples from U-20 WW and UE-19c WW, indicating that WW-8 water contains greater amounts of younger, or more locally derived recharge than water from Pahute Mesa, which has more-negative compositions. Higher concentrations of radiocarbon in WW-8 (24.9 and 25 percent modern carbon for samples collected in 1993 and 1997, respectively) are consistent with a greater component of local recharge in WW-8 water, as compared to lower radiocarbon concentrations in groundwater from U-20 WW and UE-19c WW (8.6 and 9.2 percent modern carbon, respectively). 

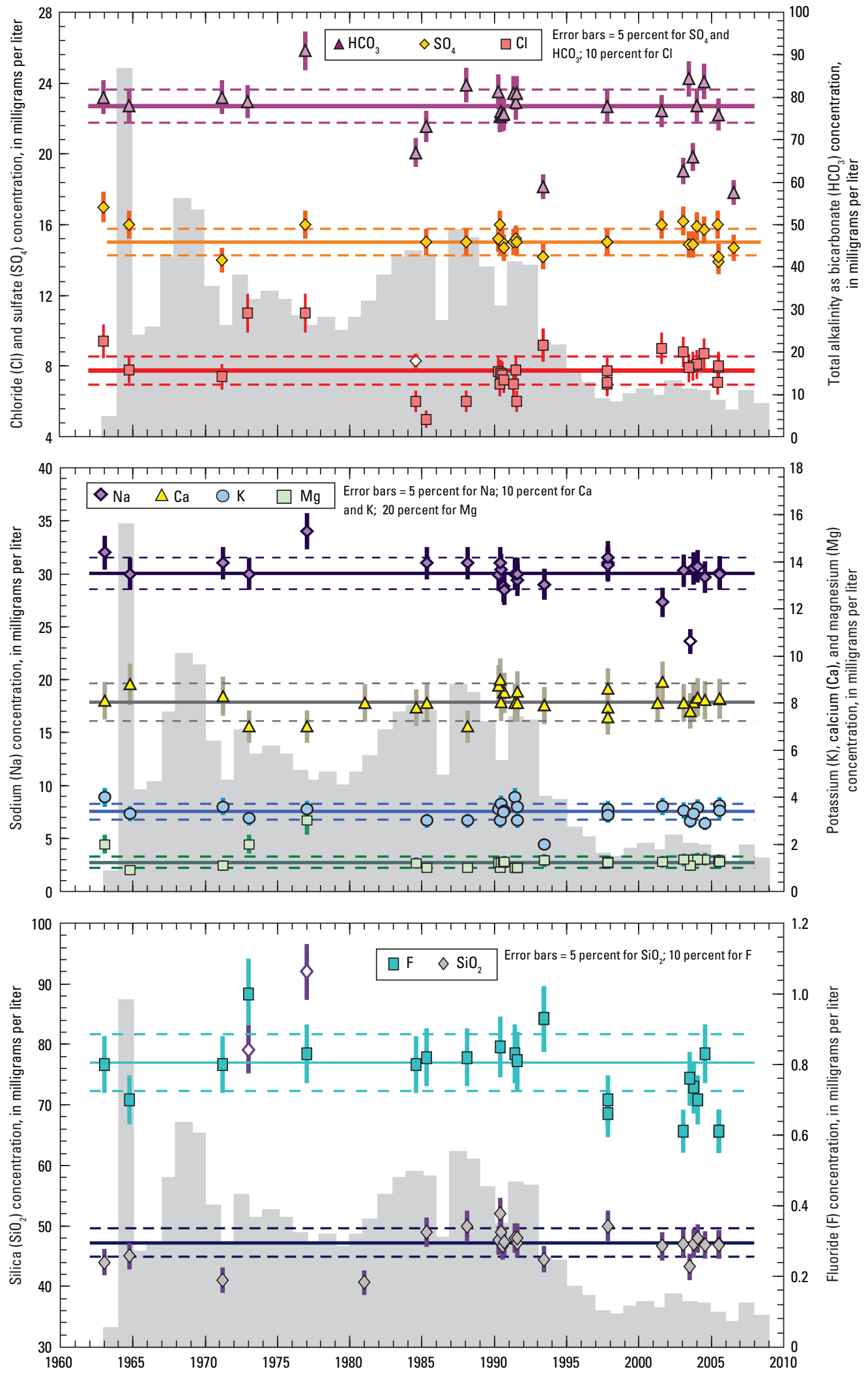

Figure 48. Temporal variations in major-ion concentrations for water samples collected from WW-8, Nevada National Security Site, Nye County, Nevada. Filled symbols represent data from appendix B used to calculate trend analyses and quantitative statistics (see results in appendix $\mathrm{D}$ and appendix $\mathrm{F}$, respectively). Open symbols represent outliers and were not included in numerical evaluations. Solid horizontal lines represent median concentration values shown along with estimated measurement error (dashed horizontal lines) using the same values given for error bars on individual analyses. Shaded histogram represents annual groundwater withdrawals from WW-8 (see appendix E, fig. E-47 for withdrawal values). 

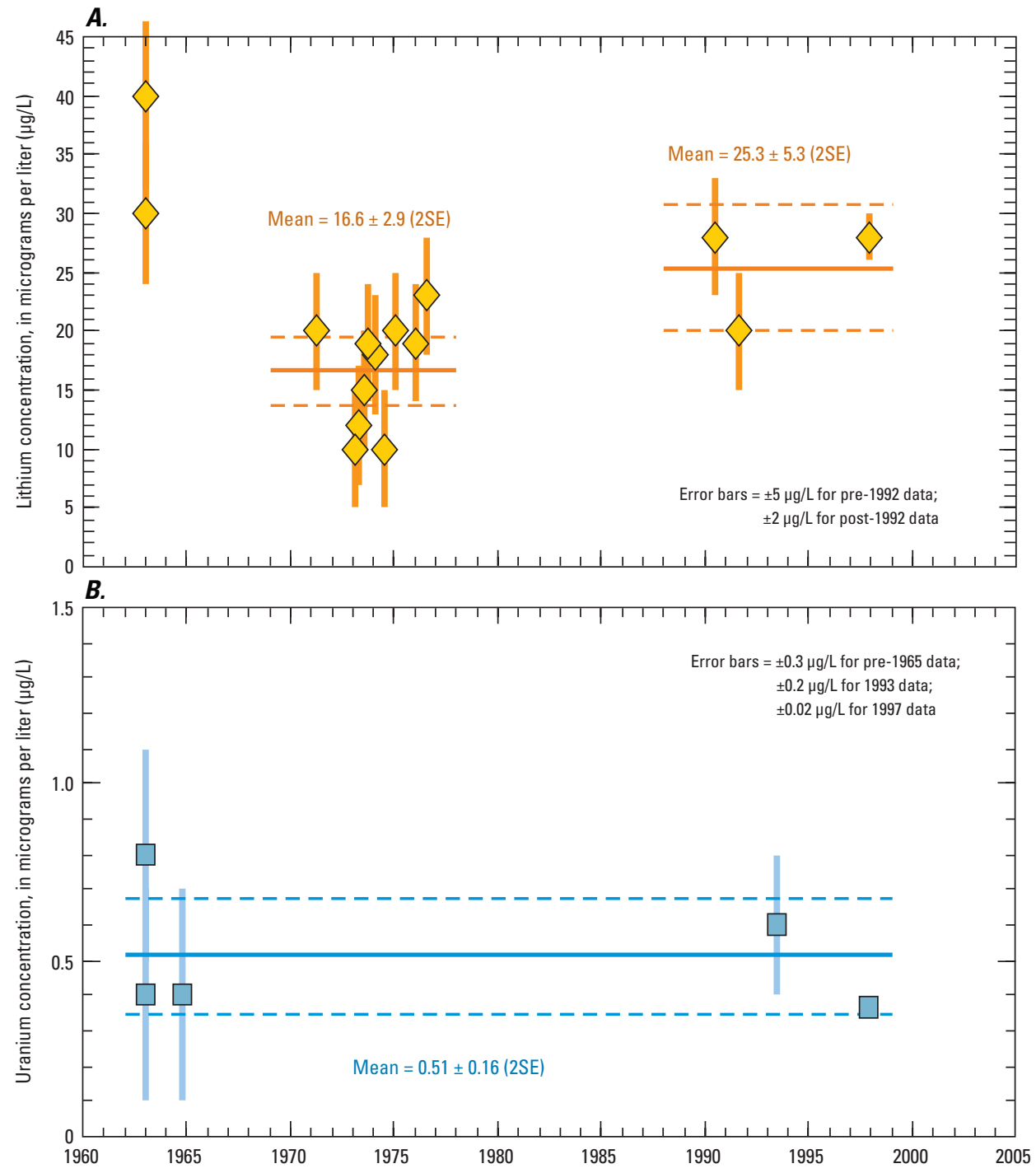

Figure 49. Temporal variations in $(A)$ lithium and $(B)$ uranium concentrations for water samples collected from WW-8, Nevada National Security Site, Nye County, Nevada. Mean and two-times standard error uncertainties (2SE) are shown by solid and dashed horizontal lines, respectively. 


\section{WW-A}

Borehole Description and Water Withdrawals: WW-A is in Yucca Flat in Area 3 of the NNSS (fig. 1; table 1). The borehole was drilled to a depth of 1,870 ft in September 1960. The single completion in the borehole, well $W W-A(1870 \mathrm{ft})$, is cased to its total depth with a slotted interval from 1,608 to $1,870 \mathrm{ft}$. The annular space between the casing and borehole is open from $1,555 \mathrm{ft}$ to the bottom of the hole (appendix E, fig. E-49). The mean water level in the well is at a depth of $1,603 \mathrm{ft}$ below land surface.

The borehole penetrates alluvium from land surface to the bottom of the hole, which consists of poorly sorted silts, sands and gravels, with some clayey deposits possibly of lacustrine origin (appendix E, fig. E-49; Wood, 2007). The percentage of tuffaceous sediment in the alluvium generally increases with depth. Water from the well is produced from permeable units within the alluvial aquifer (Bechtel Nevada, 2006; Fenelon and others, 2010, appendix 3).

WW-A was constructed to study groundwater movement beneath central Yucca Flat and later was used to supply water for activities in Yucca Flat between 1961 and 1988. About $882 \mathrm{Mgal}$ of water were withdrawn from the well (appendix E, fig. E-50). Water production ceased in 1988 (Gonzalez, 1989, p. 29; Lyles, 1993, p. 5); however, the well continues to be used for water-level monitoring. After 1988, a bailer was used to collect water samples from discrete depths in the well.
Water Quality: Water pumped from WW-A is dominated by $\mathrm{Na}, \mathrm{Ca}$, and $\mathrm{HCO}_{3}$ ions (appendix B), resulting in compositions consistent with a mixture of volcanic and carbonate components constituting the alluvial aquifer. Cations plot in a tight cluster on a trilinear diagram of major ions (appendix E, fig. E-51), implying a narrow range of compositions from different samples. However, anions distinguish two types of water depending on when samples were taken. Samples collected while the well was pumping from 1961 to 1988 form a tight cluster near the $\mathrm{HCO}_{3}$ apex on the anion plot. Subsequent bailed samples collected from 1999 to 2005 show a range of anion compositions generally having lower $\mathrm{HCO}_{3}$ and higher $\mathrm{SO}_{4}$ and $\mathrm{Cl}$ concentrations.

Measurements of specific conductance made between 1960 and 1988 show limited variations about a median value of $393 \mu \mathrm{S} / \mathrm{cm}$ and a mean value of $388 \pm 8.5$ (2SE) $\mu \mathrm{S} / \mathrm{cm}$ (fig. 50). Differences in annual water withdrawals for this period do not appear to have affected the conductance of pumped water. Parametric and nonparametric tests of trend confirm the absence of systematic changes over the period of pumping (table 18; appendix D-16). In contrast, conductance measured from bailed samples collected in the 2000s are slightly more dilute (mean value of $362 \pm 6.3$ [2SE] $\mu \mathrm{S} / \mathrm{cm}$ ) than pumpled samples. The difference between the two means is statistically significant at high degrees of significance (greater than 99.9 percent confidence limit for parametric and nonparametric tests), reflecting a distinct change in water compositions sampled from the well after pumping ceased.

Table 18. Results of trend analyses for major constituents in water pumped from WW-A, Nevada National Security Site, Nye County, Nevada, between September 21, 1960, and February 16, 1988.

[A bbreviations: MK, Mann-Kendall test; SES = Sen's estimator of slope test; LR, linear regression; -, not applicable]

\begin{tabular}{lclcccc}
\hline \multicolumn{1}{c}{ Constituent } & $\begin{array}{c}\text { Total } \\
\text { samples }\end{array}$ & $\begin{array}{c}\text { Normality } \\
\text { tests }\end{array}$ & $\begin{array}{c}\text { MK } \\
\text { result }\end{array}$ & $\begin{array}{c}\text { SES } \\
\text { result }\end{array}$ & $\begin{array}{c}\text { Residual } \\
\text { normality } \\
\text { test }\end{array}$ & $\begin{array}{c}\text { LR } \\
\text { result }\end{array}$ \\
\hline Conductivity & 12 & inconclusive & no trend & no trend & passed & no trend \\
Calcium $(\mathrm{Ca})$ & 14 & failed & no trend & no trend & - & - \\
Magnesium $(\mathrm{Mg})$ & 14 & failed & no trend & no trend & - & - \\
Sodium $(\mathrm{Na})$ & 14 & passed & no trend & no trend & failed & - \\
Potassium $(\mathrm{K})$ & 14 & passed & no trend & no trend & passed & no trend \\
Chloride $(\mathrm{Cl})$ & 15 & failed & no trend & no trend & - & - \\
Bicarbonate $\left(\mathrm{HCO}_{3}\right)$ & 15 & failed & no trend & no trend & - & - \\
Sulfate $\left(\mathrm{SO}_{4}\right)$ & 13 & inconclusive & no trend & no trend & inconclusive & no trend \\
Silicon dioxide $\left(\mathrm{SiO}_{2}\right)$ & 12 & failed & no trend & no trend & - & - \\
Fluoride $(\mathrm{F})$ & 14 & passed & no trend & no trend & passed & no trend \\
\hline
\end{tabular}


A.

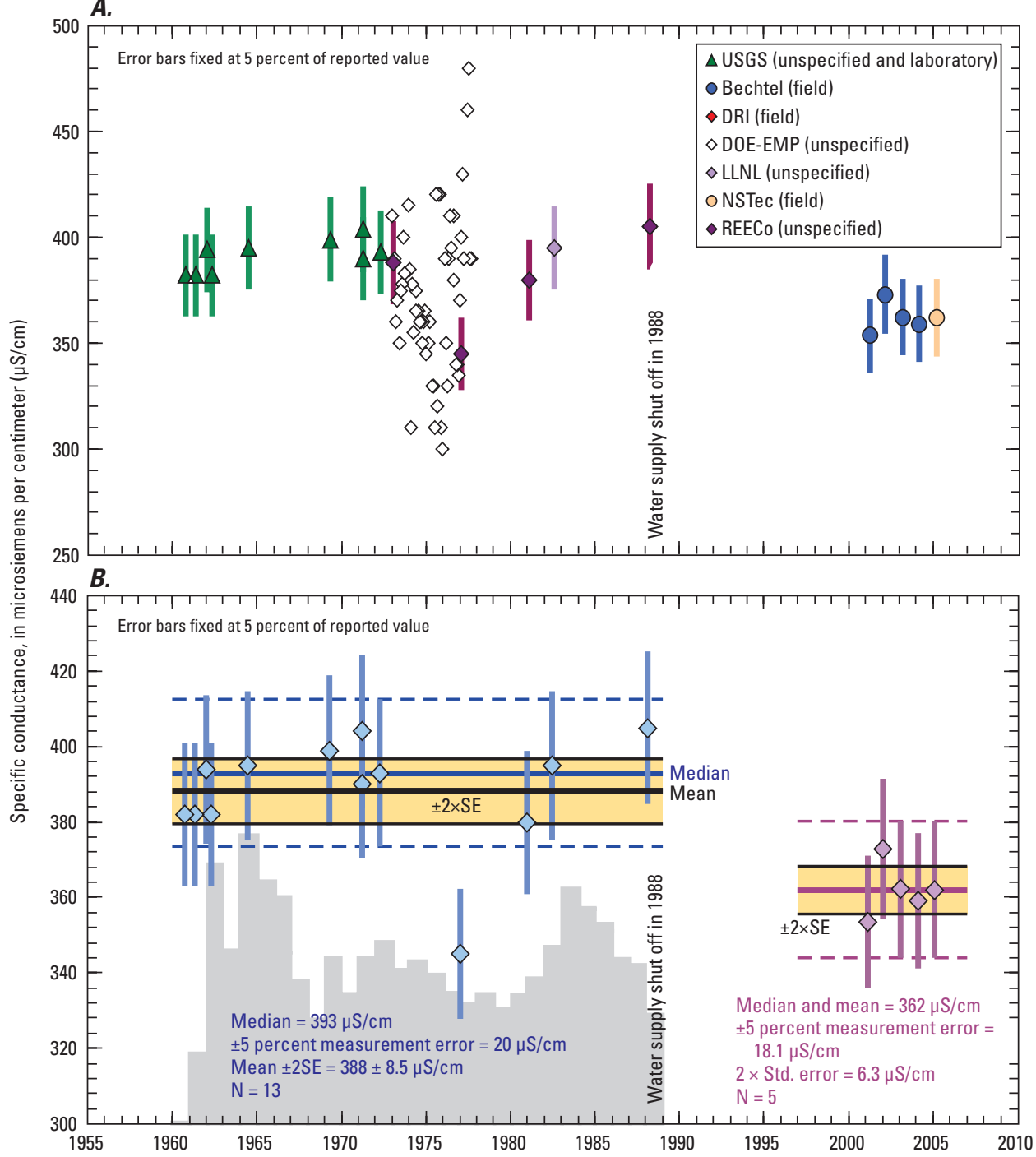

Figure 50. Temporal variations in specific conductance for water samples collected from WW-A, Nevada National Security Site, Nye County, Nevada. (A) All available specific conductance data from appendix $A$, identified by source including Bechtel, Bechtel Nevada; DOE-EMP, Department of Energy Environmental Monitoring Program; DRI, Desert Research Institute; LLNL, Lawrence Livermore National Laboratory; NSTec, National Security Technologies, LLC; REECo, Reynolds Electrical \& Engineering Co., Inc.; and USGS, U.S. Geological Survey. Reported measurements were either made in the field, the laboratory, or were unspecified in the database. (B) Specific conductance data used to calculate the median value and trend analysis. Thick, horizontal blue line represents the median value for samples collected from 1960 to 1988 during the period of active pumping shown along with estimates for 5 percent measurement error (dashed blue lines). The thick, horizontal and dashed magenta lines represent the median value and measurement errors, respectively, for bailed samples collected from 2001 to 2005. Mean and two-times standard error (2SE) values for these two data sets are shown as orange bands. Shaded histogram represents annual groundwater withdrawals from WW-A (see appendix E, fig. E-50 for withdrawal values). 
Major ion concentrations in water sampled from WW-A (appendix B) also indicate large differences between earlier pumped and later bailed samples. Major ion concentrations remained relatively constant during the period of pumping (fig. 51), although several constituents show scatter well beyond expected analytical uncertainties about median values (especially $\mathrm{Cl}, \mathrm{SO}_{4}, \mathrm{~K}$, and $\mathrm{F}$ ). Despite these fluctuations, there is no obvious compositional response to variations in pump rate. Results of statistical tests of trend confirm the absence of statistically significant monotonic shifts in composition during the period of pumping (table 18; appendix D-16). Despite the relatively uniform compositions obtained from pumped samples, all major ions show large shifts in concentration in bailed samples collected in 1999, almost 10 years after pumping ceased, and in the 2000s. Variations in concentration commonly show systematic trends that are not explained by simple progressive mixing of more concentrated and dilute end members. For example, $\mathrm{SO}_{4}$ concentrations almost doubled from 1988 (21 mg/L) to 1999 (34.5 mg/L) but progressively decreased over the next 6 years to a value of $3.2 \mathrm{mg} / \mathrm{L}$ in 2005, which is 10 -times lower than the average value for pumped samples. Concentrations of $\mathrm{HCO}_{3}$ show a similar pattern, but in the opposite sense. Chloride concentrations increased by more than a factor of three from a mean value of $7.3 \mathrm{mg} / \mathrm{L}$ for pumped samples to values between 22 and $25 \mathrm{mg} / \mathrm{L}$ for samples collected in the 2000s. Concentration shifts for cations are not as pronounced as anions; however, there is a high degree of inter-element coherence, which is why the recent bailed samples remain tightly clustered with the earlier samples on the trilinear plot (appendix E, fig. E-51). Concentrations of $\mathrm{SiO}_{2}$ show a large shift to progressively lower values with time, resulting in a 3 -fold decrease from the mean value of $74 \mathrm{mg} / \mathrm{L}$ for pumped samples to a value of $20.3 \mathrm{mg} / \mathrm{L}$ in the 2005 sample.

Trace element concentrations are reported only for pumped samples (appendix C). Most results are semiquantitative and cannot be used to evaluate temporal changes. Isotopic compositions of $\mathrm{H}$ and $\mathrm{O}$ have been determined for only one sample from WW-A collected in 1982 (fig. 52; appendix C). Isotopic compositions are intermediate within the range for NNSS groundwater; however, the veracity of this single analysis may be suspect because the resulting point plots farther away from the global meteoric water line than almost all other NNSS samples. 

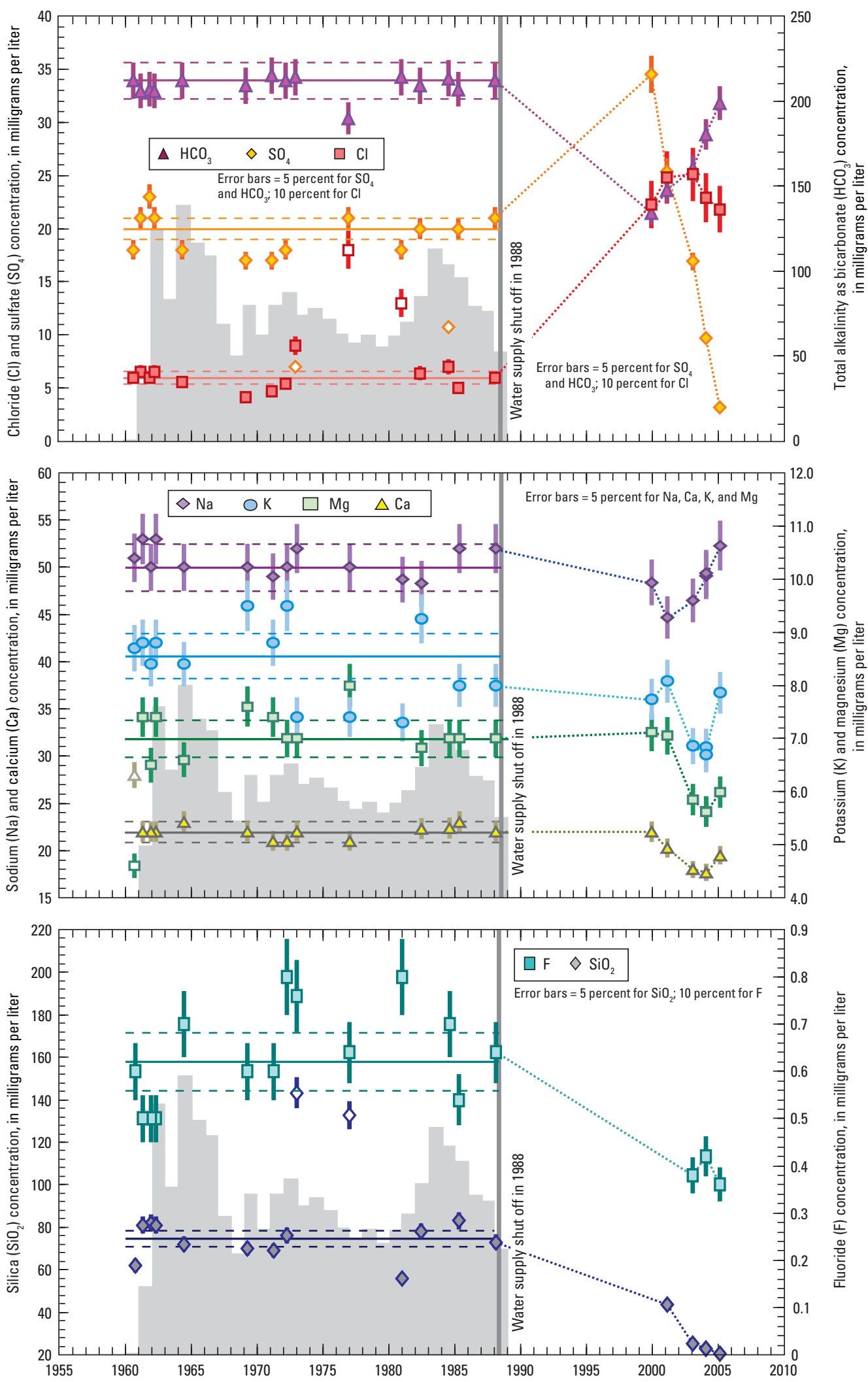

Figure 51. Temporal variations in major-ion concentrations for water samples collected from WW-A, Nevada National Security Site, Nye County, Nevada. Filled symbols represent data from appendix B used to calculate trend analyses and quantitative statistics for samples collected from September 1960 to February 1988 during the period of active pumping (see results in appendix D and appendix $F$, respectively). Open symbols represent outliers and were not included in numerical evaluations. Solid horizontal lines represent median concentration values shown along with estimated measurement error (dashed horizontal lines) using the same values given for error bars on individual analyses. Shaded histogram represents annual groundwater withdrawals from WW-A (see appendix E, fig. E-50 for withdrawal values). 


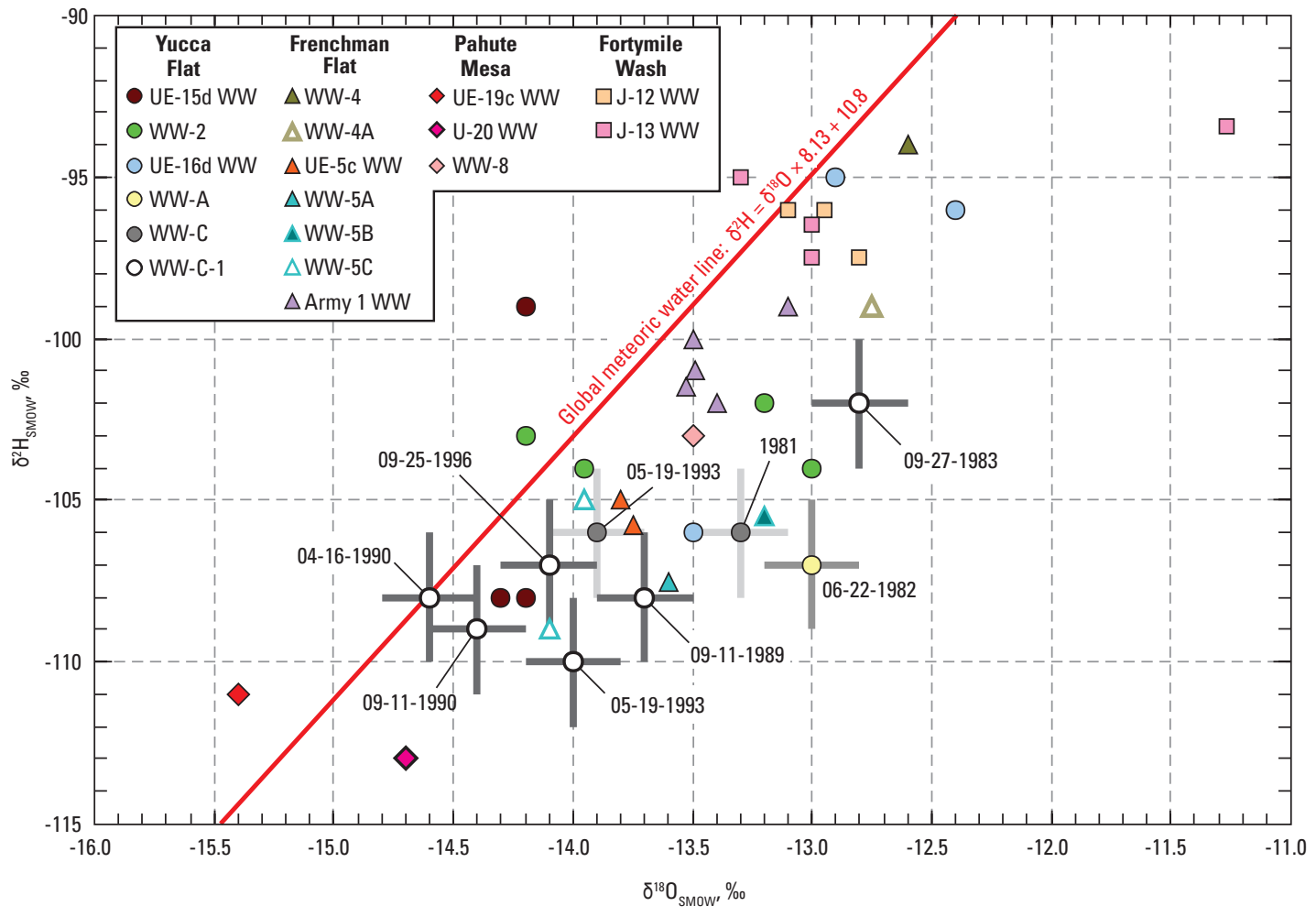

Figure 52. Isotopic compositions of hydrogen and oxygen for water samples from WW-A, WW-C, and WW-C-1 in southern Yucca Flat, and data from other water-supply wells from the Nevada National Security Site, Nye County, Nevada. 
WW-C

Borehole Description and Water Withdrawals: WW-C is at the southern end of Yucca Flat in Area 6 of the NNSS (fig. 1; table 1). The borehole was drilled to a depth of 1,701 ft in March 1961, and was later recompleted in April 1967. Borehole WW-C has had two well-completion intervals during its withdrawal history (Elliott and Moreo, 2011). Well WW-C (1373-1701 ft) was completed in March 1961. This completion was cased to the bottom of the hole and had a slotted interval from 1,571 to 1,679 ft. The annular space between the casing and borehole was open from 1,373 to $1,701 \mathrm{ft}$. This completion was used until the well was recompleted in April 1967, when the existing borehole was reamed from 1,500 to $1,622 \mathrm{ft}$. Well $W W-C$ (recompleted) is cased to a depth of $1,624 \mathrm{ft}$ and has a slotted interval from 1,560 to $1,624 \mathrm{ft}$ and an open annular space from 1,373 to $1,701 \mathrm{ft}$ (appendix E, fig. E-52). The mean water level in the final completion, well $W W-C$ (recompleted), is at a depth of $1,543 \mathrm{ft}$ below land surface.

The borehole penetrates argillic siltstone and alluvium from 0 to $215 \mathrm{ft}$, welded and nonwelded tuffs from 215 to $1,355 \mathrm{ft}$, and Paleozoic limestone and dolomitic limestone from 1,355 $\mathrm{ft}$ to the bottom of the hole (appendix E, fig. E-52; Warren and others, 2003). Water produced from the well is derived from fractures in the limestone (Garber and Thordarson, 1962, p. 27) that compose the lower caronate aquifer (Bechtel Nevada, 2006; Fenelon and others, 2010, appendix 3).
WW-C originally was drilled to investigate groundwater flow beneath Yucca Flat and later was used as a supply well from 1961 to 1995 . Of the 1,280 Mgal of water pumped from WW-C, about 84 percent was produced after the well was recompleted in April 1967 (appendix E, fig. E-53). Water has not been sampled for water-quality analysis since May 1993.

Water Quality: Water pumped from WW-C is dominated by $\mathrm{Na}$ and $\mathrm{HCO}_{3}$ components with substantial amounts of $\mathrm{Ca}$ and $\mathrm{Mg}$ (appendix B). Analyses plot in a small cluster on a trilinear diagram of major ions (appendix E, fig. E-54), which indicates a restricted range of compositions throughout the sampling history. Cation concentrations in water from WW-C are not as enriched in $\mathrm{Ca}$ and $\mathrm{Mg}$ as water from other supply wells that also pump water from the lower carbonate aquifer (for example, well completions in boreholes Army 1 WW, WW-2, and UE-16d WW, fig. 2). However, anion concentrations are comparable to other wells open to the lower carbonate aquifer consisting mostly of $\mathrm{HCO}_{3}$ (approximately 80 percent of all anions) with small, subequal proportions of $\mathrm{SO}_{4}$ and $\mathrm{Cl}$.

Measurements of specific conductance made during pumping from both completions in WW-C show limited variations about a median value of $1,040 \mu \mathrm{S} / \mathrm{cm}$ (fig. 53). Systematic changes in conductance with time are not obvious, but both nonparametric tests of trend indicate a systematic increase in conductance with time (table 19; $\underline{\text { appendix D-17). }}$

Table 19. Results of trend analyses for major constituents in water pumped from WW-C, Nevada National Security Site, Nye County, Nevada, between April 25, 1962, and May 19, 1993.

[A bbreviations: MK, Mann-Kendall test; SES, Sen's estimator of slope test; LR, linear regression; -, not applicable]

\begin{tabular}{lcllccc}
\hline \multicolumn{1}{c}{ Constituent } & $\begin{array}{c}\text { Total } \\
\text { samples }\end{array}$ & $\begin{array}{c}\text { Normality } \\
\text { tests }\end{array}$ & $\begin{array}{c}\text { MK } \\
\text { result }\end{array}$ & $\begin{array}{c}\text { SES } \\
\text { result }\end{array}$ & $\begin{array}{c}\text { Residual } \\
\text { normality } \\
\text { test }\end{array}$ & $\begin{array}{c}\text { LR } \\
\text { result }\end{array}$ \\
\hline Conductivity & 16 & passed & increasing & increasing & passed & no trend \\
Calcium $(\mathrm{Ca})$ & 17 & inconclusive & no trend & no trend & passed & no trend \\
Magnesium $(\mathrm{Mg})$ & 19 & passed & no trend & no trend & passed & inconclusive \\
Sodium $(\mathrm{Na})$ & 17 & passed & no trend & no trend & passed & no trend \\
Potassium $(\mathrm{K})$ & 17 & passed & no trend & no trend & passed & no trend \\
Chloride $(\mathrm{Cl})$ & 19 & failed & no trend & no trend & - & - \\
Bicarbonate $\left(\mathrm{HCO}_{3}\right)$ & 17 & passed & no trend & no trend & failed & - \\
Sulfate $\left(\mathrm{SO}_{4}\right)$ & 17 & inconclusive & no trend & no trend & passed & no trend \\
Silicon dioxide $\left(\mathrm{SiO}_{2}\right)$ & 15 & passed & no trend & no trend & failed & - \\
Fluoride $(\mathrm{F})$ & 13 & failed & no trend & no trend & - & - \\
\hline
\end{tabular}




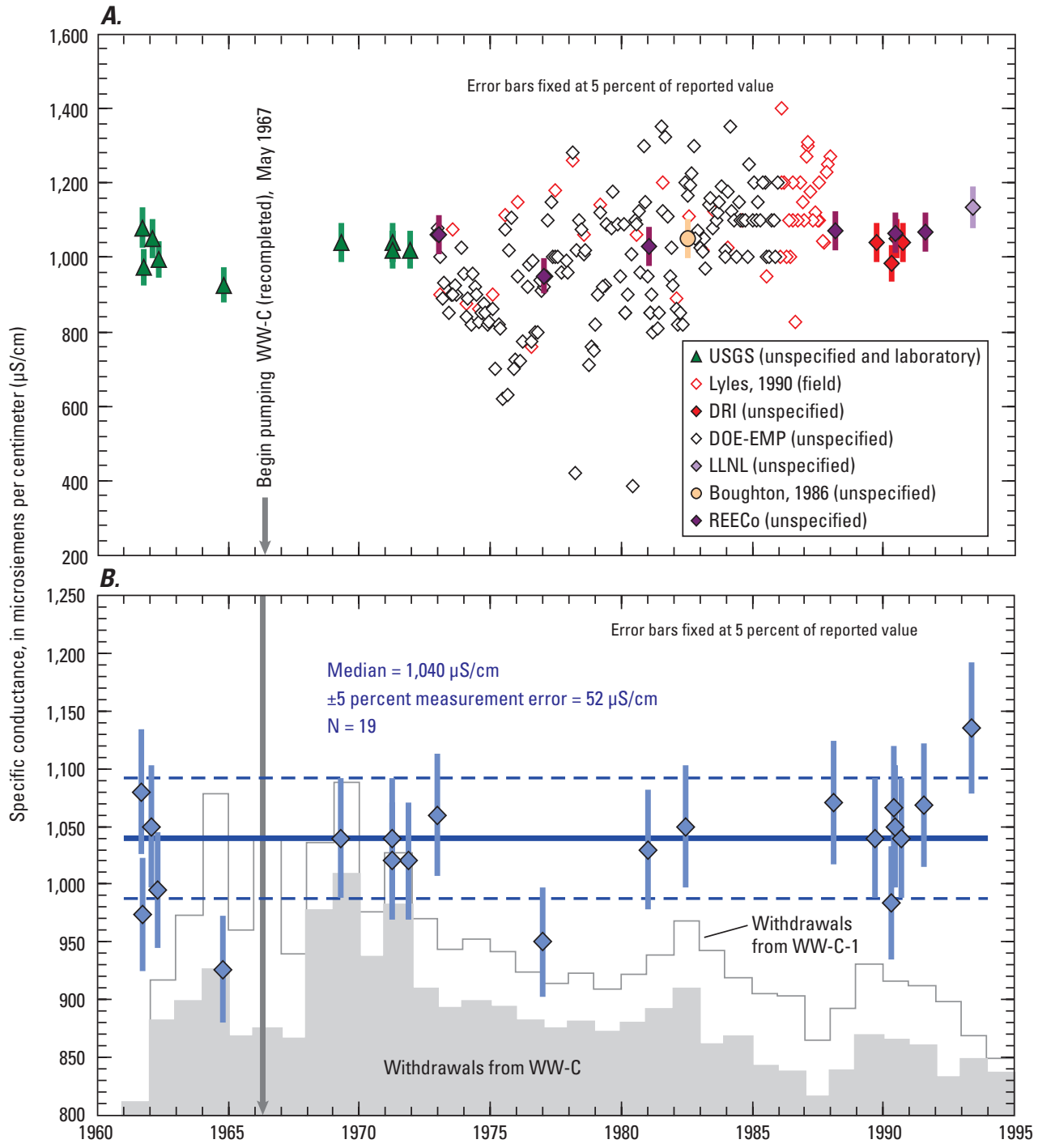

Figure 53. Temporal variations in specific conductance for water samples collected from WW-C, Nevada National Security Site, Nye County, Nevada. (A) All available specific conductance data from appendix A, identified by source including Boughton, 1986; DOE-EMP, Department of Energy Environmental Monitoring Program; DRI, Desert Research Institute; LLNL, Lawrence Livermore National Laboratory; Lyles, 1990; REECo, Reynolds Electrical \& Engineering Co., Inc.; and USGS, U.S. Geological Survey. Reported measurements were either made in the field, the laboratory, or were unspecified in the database. (B) Specific conductance data used to calculate the median value and trend analysis. Thick, horizontal blue line represents the median value shown along with estimates for 5 percent measurement error (dashed blue lines). Shaded histogram represents annual groundwater withdrawals from WW-C, and the unshaded histogram represents withdrawals from nearby WW-C-1 (see appendix E, fig. E-53 for withdrawal values). 
However, linear regression results of conductance compared with time do not indicate a trend at the 95-percent confidence level. The linear regression is considered a more robust statistical indicator because conductance data pass criteria for assuming a normal distribution of data and regression residuals. Statistical tests of early and late samples, grouped on the basis of differences in pumping rates using either 1980 or 1985 as a break (fig. 53B), indicate the difference in conductance is significant at levels between 90 and 95 percent. However, these results are strongly influenced by two low values measured in 1964 and 1977. No statistical difference is present if these two values are excluded. These data are interpreted as evidence that, if a shift in dissolved ion content in water from WW-C does exist as a result of more than 34 years of pumping from two different completions, only a slight change in conductance is likely.

As with conductance, major ion concentrations of water from WW-C show only small amounts of scatter that are largely within expected analytical uncertainty of the median concentrations (fig. 54; appendix B). The first two samples collected in September 1961 and January 1962 were collected prior to and one week after the start of continuous pumping in the well, and are not considered representative of groundwater in the aquifer. The third sample was collected four months after pumping began. Parametric and nonparametric tests of trend in ion concentrations for the remaining samples show no indications that concentrations shifted systematically with time (appendix D-17), except for a possible increase in $\mathrm{Mg}$ concentration. Results from Mann-Whitney and two-sample t-tests on data separated into early and late groups, as described previously in this section for specific conductance, show no statistical difference at the 95-percent confidence level for all elements. These results are consistent with specific-conductance data and indicate that major ion concentrations remained constant in water pumped from WW-C regardless of the completion and differences in early and late pumping rates in the well.

Trace element concentrations are available for water samples from both completions in WW-C (appendix C). Although variations in data quality over the years of sample analysis complicate evaluation of temporal trends, data for As, B, Ba, Li, Sr, and U are considered to be reasonably reliable and have remained relatively constant through the period of groundwater withdrawal. Individual concentrations commonly deviate less than 20 percent from mean values and no progressive shifts in concentration are apparent with time (fig. 55).

Isotopic compositions of $\mathrm{H}$ and $\mathrm{O}$ reported for two water samples collected from WW-C in 1981 and 1993 (fig. 52; appendix C) are similar to water from WW-A in southern Yucca Flat, and UE-5c WW, WW-5A, WW-5B, and WW-5C in Frenchman Flat. The two $\delta^{2} \mathrm{H}$ values in WW-C are identical ( $-106 \%$ for both samples) but the $\delta^{18} \mathrm{O}$ values differ beyond expected analytical uncertainties $(-13.3$ and $-13.9 \%$ with an expected analytical uncertainty of $0.2 \%$ ). Given the strong evidence for compositional uniformity in WW-C samples through time (including identical $\delta^{2} \mathrm{H}$ values), it is likely that the differences in $\delta^{18} \mathrm{O}$ are analytical artifacts rather than differences in groundwater evolution. 

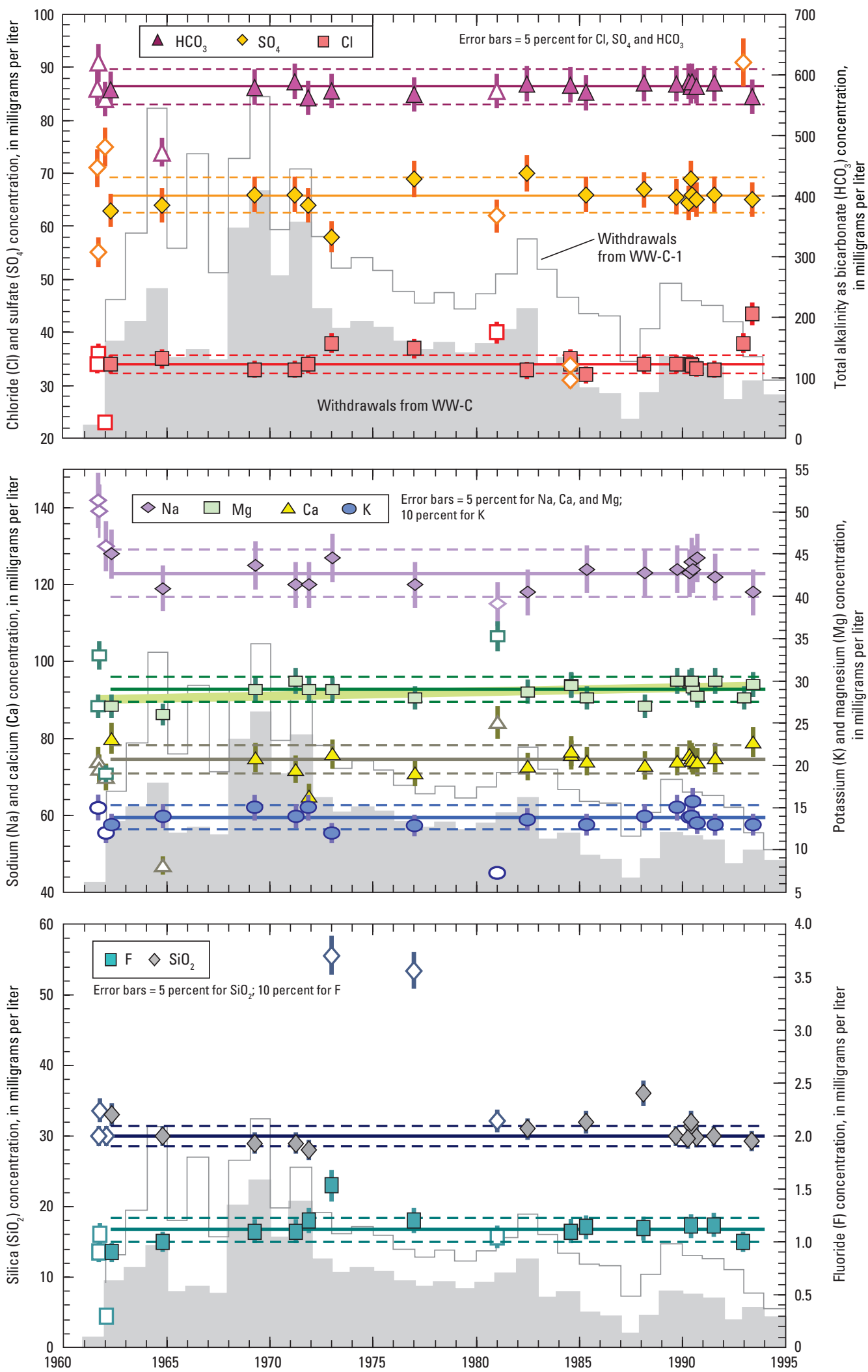

Figure 54. Temporal variations in major-ion concentrations for water samples collected from WW-C, Nevada National Security Site, Nye County, Nevada. Filled symbols represent data from appendix B used to calculate trend analyses and quantitative statistics (see results in appendix D and appendix $F$, respectively). Open symbols represent outliers and were not included in numerical evaluations. Solid horizontal lines represent median concentration values shown along with estimated measurement error (dashed horizontal lines) using the same values given for error bars on individual analyses. Thick sloping line represents a statistically significant trend in $\mathrm{Mg}$. Shaded histogram represents annual groundwater withdrawals from WW-C, and the unshaded histogram represents withdrawals from nearby WW-C-1 (see appendix E, fig. E-53 for withdrawal values). 


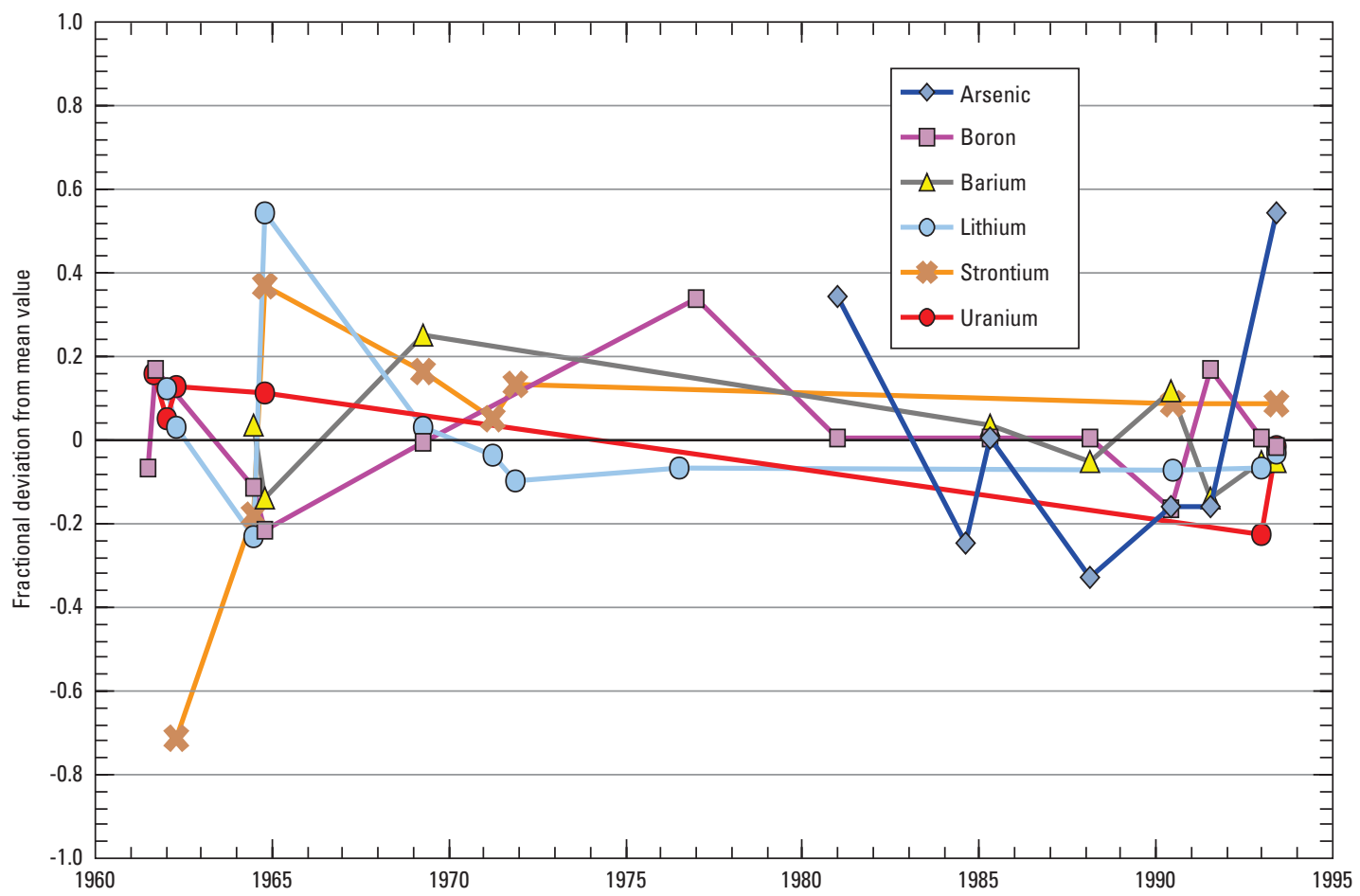

Figure 55. Deviation of selected trace element concentrations from mean values for water samples collected from WW-C, Nevada National Security Site, Nye County, Nevada. 


\section{WW-C-1}

Borehole Description and Water Withdrawals: WW-C-1 is at the southern end of Yucca Flat in Area 6 of the NNSS, approximately $100 \mathrm{ft}$ southeast of WW-C (fig. 1; table 1). The borehole originally was drilled to a depth of $1,707 \mathrm{ft}$ in April 1962. The hole was subsequently sidetracked at 1,389 $\mathrm{ft}$ and the sidetrack hole was drilled and cased to a depth of 1,650 ft in June 1962. This single completion in the borehole, well $W W-C-1$, contains perforated casing from 1,536 to $1,650 \mathrm{ft}$, and the annular space between the casing and borehole is open from 914 to 1,650 ft (appendix E, fig. E-55). The mean water level in the well is at a depth of $1,539 \mathrm{ft}$ below land surface.

The borehole penetrated alluvium from 0 to $215 \mathrm{ft}$, welded and nonwelded tuff from 215 to 1,305 ft, and limestone from 1,305 to 1,650 ft (appendix E, fig. E-55; Wood, 2007). Water pumped from the well is produced from fractures in the limestone, specifically the interval from 1,607 to 1,623 ft (Winograd and Thordarson, 1975, table 3). The limestone is part of the lower carbonate aquifer (Bechtel Nevada, 2006; Fenelon and others, 2010, appendix 3).
WW-C-1 was constructed to supply water for work activities in southern Yucca Flat. About 1,140 Mgal of water have been withdrawn from the well since June 1962 (appendix E, fig. E-56). The well was deactivated for general use in 2005 because of elevated total dissolved solids and hardness (Wills, 2006, p. 4-24), but the well continues to provide water for construction activities in Area 6 (U.S. Department of Energy, 2008, table 2-1).

Water Quality: Water pumped from WW-C-1 has compositions that are nearly identical to water pumped from the same aquifer in nearby WW-C. Data from multiple analyses plot in a tight cluster on a trilinear diagram (appendix E, fig. E-57), indicating a restricted range of compositions similar to WW-C. Median values for major elements as well as the most reliably determined trace elements and environmental isotopes in samples from WW-C-1 typically are within several percentage points of median values from WW-C (fig. 56). These data reflect the close proximity of the two wells and the fact that both wells produce water from the same hydraulically connected aquifer.

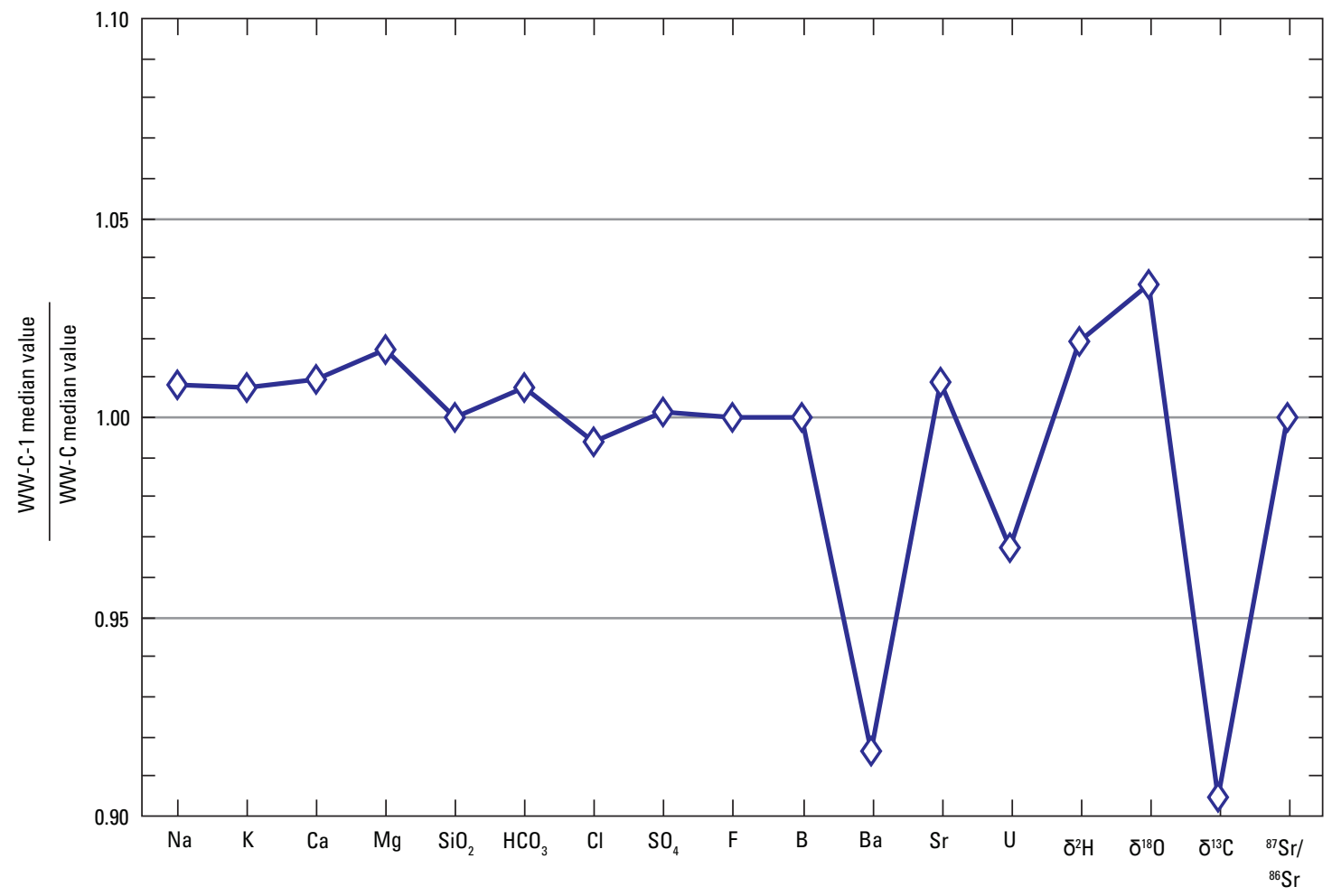

Figure 56. Median values for major ion concentrations, most reliably determined trace element concentrations, and environmental isotopes reported for water samples collected from WW-C-1 normalized to median values for the same constituents from WW-C, Nevada National Security Site, Nye County, Nevada. 
Specific-conductance measurements of water from WW-C-1 show limited variations about a median value of $1,070 \mu \mathrm{S} / \mathrm{cm}$ (fig. 57). Although most values are within expected analytical error of the mean, there is a systematic shift in values from water sampled early during the history of pumping relative to values obtained from more recent samples. Nonparametric tests of trends confirm the statistical significance of a change with time (table 20; appendix D-18). The shift may be related to a gradual change in WW-C-1 pumping from an average annual withdrawal of 28.6 Mgal/yr between 1962 and 1992, to $15.7 \mathrm{Mgal} / \mathrm{yr}$ between 1993 and 2008 (appendix E, fig. E-56). The change in water withdrawal is even more striking if withdrawals from nearby WW-C are included (unshaded histogram in fig. 57). Median values of specific conductance for samples from WW-C-1 (1,045 $\mu \mathrm{S} / \mathrm{cm}, \mathrm{N}=16)$ and WW-C $(1,040 \mu \mathrm{S} / \mathrm{cm}$, $\mathrm{N}=17$ ) are statistically indistinguishable for groundwater sampled prior to 1993 ( $\mathrm{p}$ value for Mann-Whitney test $=0.62$ ).

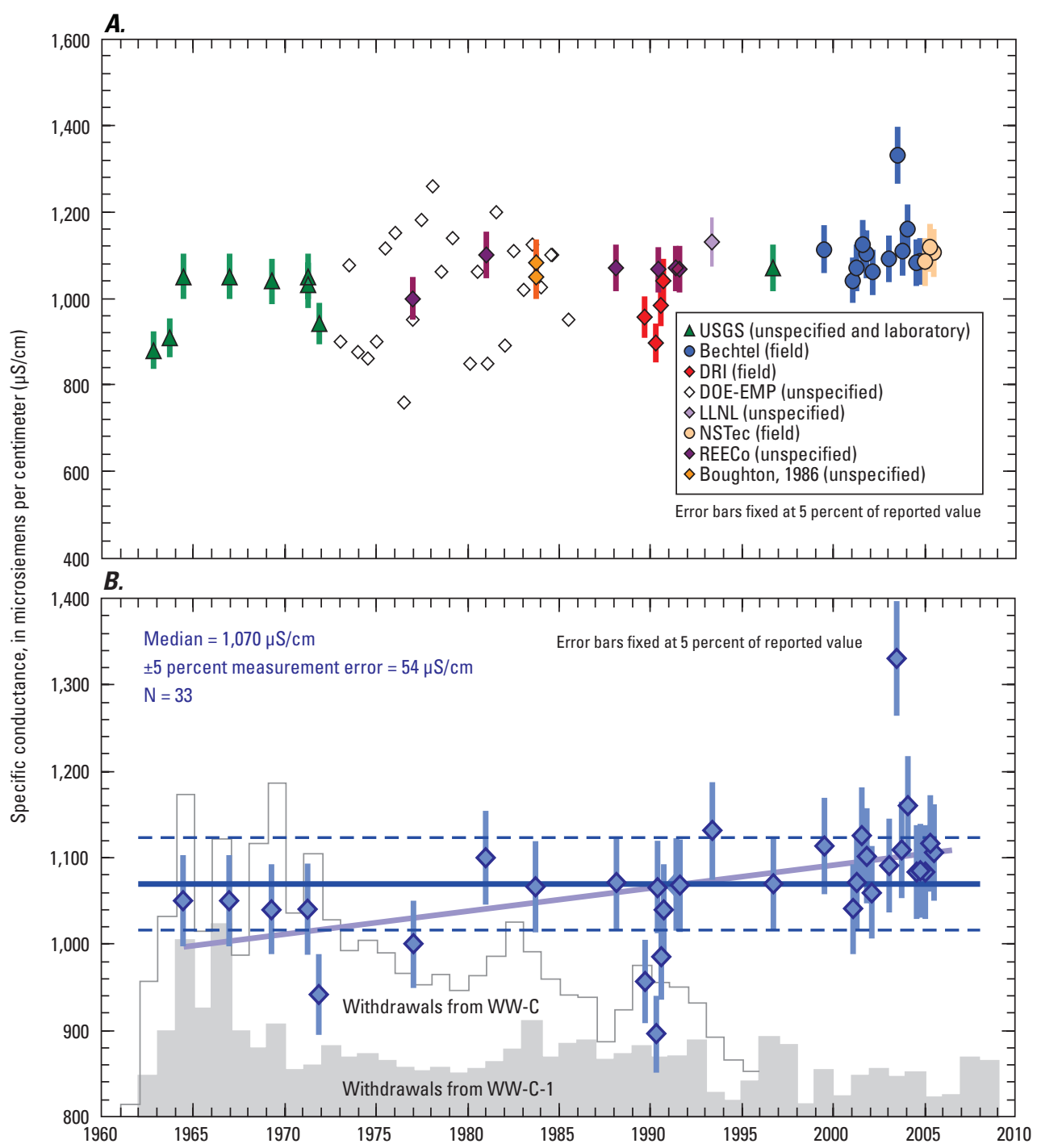

Figure 57. Temporal variations in specific conductance for water samples collected from WW-C-1, Nevada National Security Site, Nye County, Nevada. (A) All available specific conductance data from appendix A, identified by source including Bechtel, Bechtel Nevada; Boughton, 1986; DOEEMP, Department of Energy Environmental Monitoring Program; DRI, Desert Research Institute; LLNL, Lawrence Livermore National Laboratory; NSTec, National Security Technologies, LLC; REECo, Reynolds Electrical \& Engineering Co., Inc.; and USGS, U.S. Geological Survey. Reported measurements were either made in the field, the laboratory, or were unspecified in the database. $(B)$ Specific conductance data used to calculate the median value and trend analysis. Thick, horizontal blue line represents the median value shown along with estimates for 5 percent measurement error (dashed blue lines). Thick sloping line represents a statistically significant trend (see results in appendix D). Shaded histogram represents annual groundwater withdrawals from WW-C-1, and the unshaded histogram represents withdrawals from nearby WW-C (see appendix $E$, fig. E-56 for withdrawal values). 
Table 20. Results of trend analyses for major constituents in groundwater pumped from WW-C-1, Nevada National Security Site, Nye County, Nevada, between June 14, 1964, and July 12, 2005.

[A bbreviations: MK, Mann-Kendall test; SES, Sen's estimator of slope test; LR, linear regression; -, not applicable]

\begin{tabular}{lcllccc}
\hline \multicolumn{1}{c}{ Constituent } & $\begin{array}{c}\text { Total } \\
\text { samples }\end{array}$ & $\begin{array}{c}\text { Normality } \\
\text { tests }\end{array}$ & $\begin{array}{c}\text { MK } \\
\text { result }\end{array}$ & $\begin{array}{c}\text { SES } \\
\text { result }\end{array}$ & $\begin{array}{c}\text { Residual } \\
\text { normality } \\
\text { test }\end{array}$ & $\begin{array}{c}\text { LR } \\
\text { result }\end{array}$ \\
\hline Conductivity & 33 & failed & increasing & increasing & - & - \\
Calcium $(\mathrm{Ca})$ & 23 & failed & no trend & no trend & - & - \\
Magnesium $(\mathrm{Mg})$ & 26 & passed & no trend & no trend & passed & no trend \\
Sodium $(\mathrm{Na})$ & 24 & inconclusive & no trend & no trend & passed & no trend \\
Potassium $(\mathrm{K})$ & 25 & failed & no trend & no trend & - & - \\
Chloride $(\mathrm{Cl})$ & 23 & failed & no trend & no trend & - & - \\
Bicarbonate $\left(\mathrm{HCO}_{3}\right)$ & 27 & failed & no trend & no trend & - & - \\
Sulfate $\left(\mathrm{SO}_{4}\right)$ & 26 & passed & no trend & no trend & passed & no trend \\
Silicon dioxide $\left(\mathrm{SiO}_{2}\right)$ & 26 & inconclusive & no trend & no trend & failed & - \\
Fluoride $(\mathrm{F})$ & 23 & inconclusive & decreasing & no trend & passed & decreasing \\
\hline
\end{tabular}

However, separation of WW-C-1 data into early (1964-1991) and late (1993-2005) groups representing periods of greater and lesser pumping, respectively, results in conductance values that are distinct at levels of significance greater than 99 percent using the two-sample t-test (mean values of $1,027.5 \mu \mathrm{S} / \mathrm{cm}$ for early samples and $1,110.5 \mu \mathrm{S} / \mathrm{cm}$ for late samples) and nonparametric Mann-Whitney test (median values of $1,045 \mu \mathrm{S} / \mathrm{cm}$ for early samples and $1,102 \mu \mathrm{S} / \mathrm{cm}$ for late samples). Several analyses may be analytically spurious (samples collected in November 1971, September 1989, April 1990, and July 2003); however, even with these analyses removed, regression slopes remain resolvable from zero and mean values for early and late groupings remain statistically distinct. These data indicate that the subtle increases in dissolved ion content may correlate with the pumping history of WW-C-1 and WW-C.

Unlike specific-conductance data, changes in individual major ion concentrations with time for WW-C-1 (appendix B) are not apparent (fig. 58). Initial samples collected from WW-C-1 in October 1962 and September 1963 show excessive amounts of scatter attributed to transient effects related to drilling and well construction and are not included in trend analysis. Remaining data show concentrations that plot within or close to expected analytical uncertainties of calculated median values for most constituents regardless of date, and show no obvious temporal trends related to pumping history. Parametric and nonparametric tests of trend show no evidence of statistically significant monotonic shifts in concentration with time, with the exception of a decreasing trend obtained for F (table 20; appendix D-18). Data separated into early and late groups as described for specific conductance yield mean values that are statistically indistinguishable at the 95-percent confidence level for all elements except $\mathrm{F}$. It is unclear whether the deviations observed for $\mathrm{HCO}_{3}$ concentration in the three samples collected in 2003 are the result of analytical artifacts or reflect a real, short term deviation in groundwater chemistry. Because no other constituents display similar changes, analytical artifacts are considered likely. The contrasting behavior between specific conductance and major element concentrations may be caused by (1) analytical biases between different agencies responsible for early versus late conductance measurements (fig. 57A); (2) small differences in major ion species that do not result in statistically significant increases by themselves, but cumulatively contribute to increased conductivity in later samples; or (3) other unreported constituents that may contribute to conductivity (for example, nitrogen compounds or organics). 

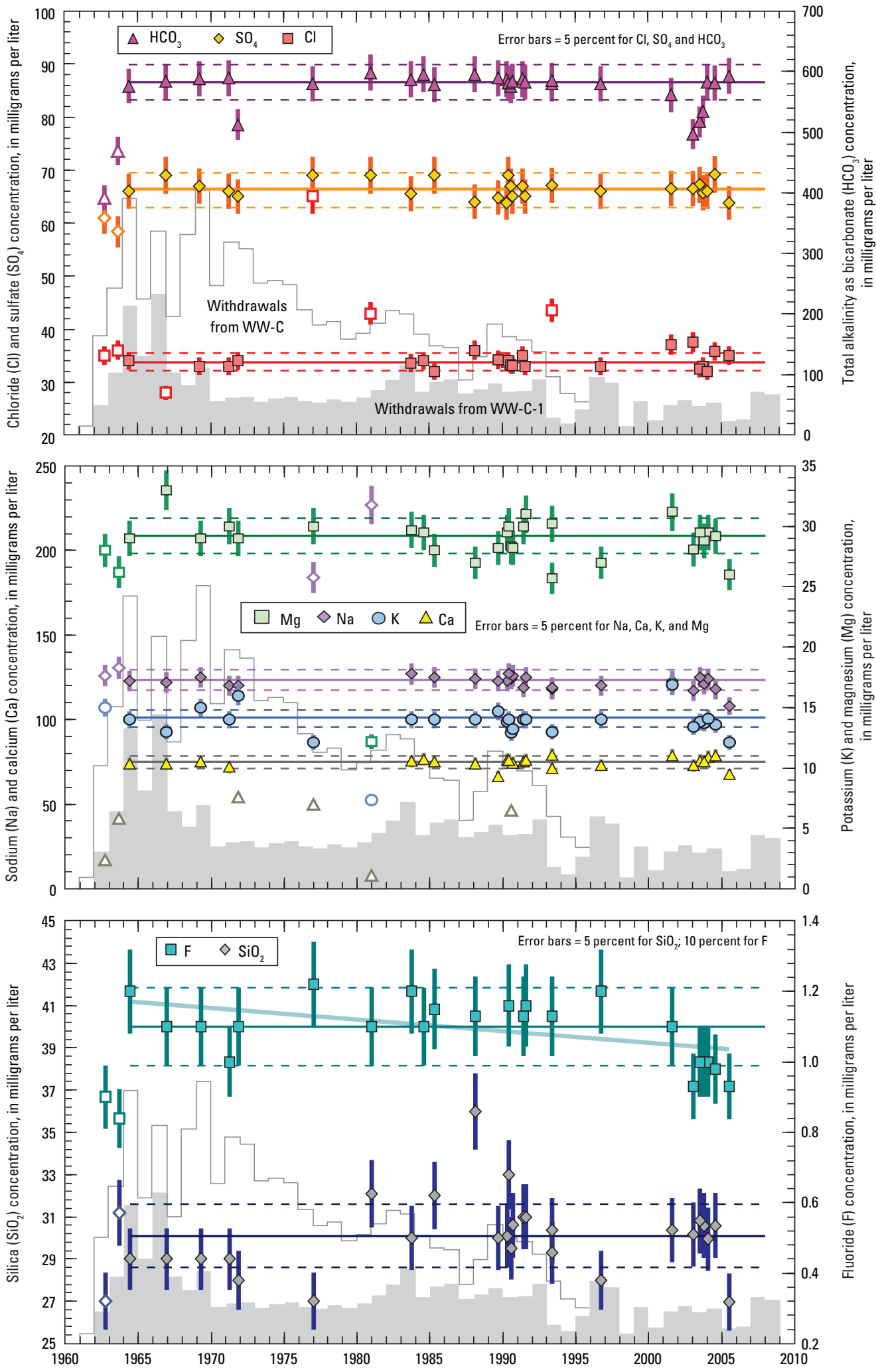

Figure 58. Temporal variations in major-ion concentrations for water samples collected from WW-C-1, Nevada National Security Site, Nye County, Nevada. Filled symbols represent data from appendix B used to calculate trend analyses and quantitative statistics (see results in appendix $\mathrm{D}$ and appendix $\mathrm{F}$, respectively). Open symbols represent outliers and were not included in numerical evaluations. Solid horizontal lines represent median concentration values shown along with estimated measurement error (dashed horizontal lines)

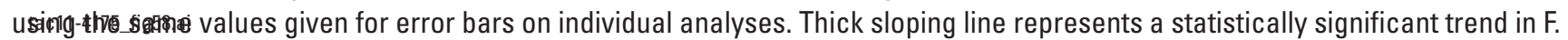
Shaded histogram represents annual groundwater withdrawals from WW-C-1, and the unshaded histogram represents withdrawals from nearby WW-C (see appendix E, fig. E-56 for withdrawal values). 
Like major ions, trace element concentrations reported for WW-C-1 show no evidence of systematic changes with time (fig. 59). Reliably determined elements analyzed since the 1960s include B, Ba, Li, Sr, and U. Variations of Ba, $\mathrm{Sr}$, and $\mathrm{U}$ concentrations typically deviate on either side of their associated mean values by less than 20 percent. Concentrations of Li and B show larger deviations from mean concentrations; however, these upward and downward deviations in concentration cannot be correlated to withdrawal history. Arsenic concentrations were reported for samples beginning in the early 1980s. Unlike results from UE-5c WW, which showed substantial increases in As concentration over several decades (fig. 18), As concentrations in WW-C-1 remained constant at 5 to $8 \mu \mathrm{g} / \mathrm{L}$ through the early 1990s.
Isotopic compositions of $\mathrm{H}$ and $\mathrm{O}$ were determined for six samples of water collected from WW-C-1 between 1983 and 1996 (fig. 52; appendix C). The sample collected in 1983 has the isotopically heaviest compositions $\left(-102 \% \delta^{2} \mathrm{H}\right.$ and $-12.8 \%$ o $\delta^{18} \mathrm{O}$ ). The other samples have analytically identical $\delta^{2} \mathrm{H}$ compositions of -110 to $-107 \%$ and a wider range of $\delta^{18} \mathrm{O}$ compositions from -14.6 to $-13.7 \%$. Systematic changes with time are not apparent. The $\delta^{2} \mathrm{H}$ compositions from WW-C-1 have analytical errors that overlap values reported from nearby WW-C; however, the five samples analyzed from 1989 to 1996 have systematically lighter (more negative) values, with a mean of $-108.4 \pm 1.0 \%$ o (2SE), compared to two measurements from WW-C that had values of 106\%. Other isotope data, including $\delta^{13} \mathrm{C}$, radiocarbon, ${ }^{36} \mathrm{Cl} / \mathrm{Cl}$, and ${ }^{87} \mathrm{Sr} /{ }^{86} \mathrm{Sr}$ compositions, reported for both wells are nearly identical within analytical uncertainties, indicating strong similarities in groundwater sources.

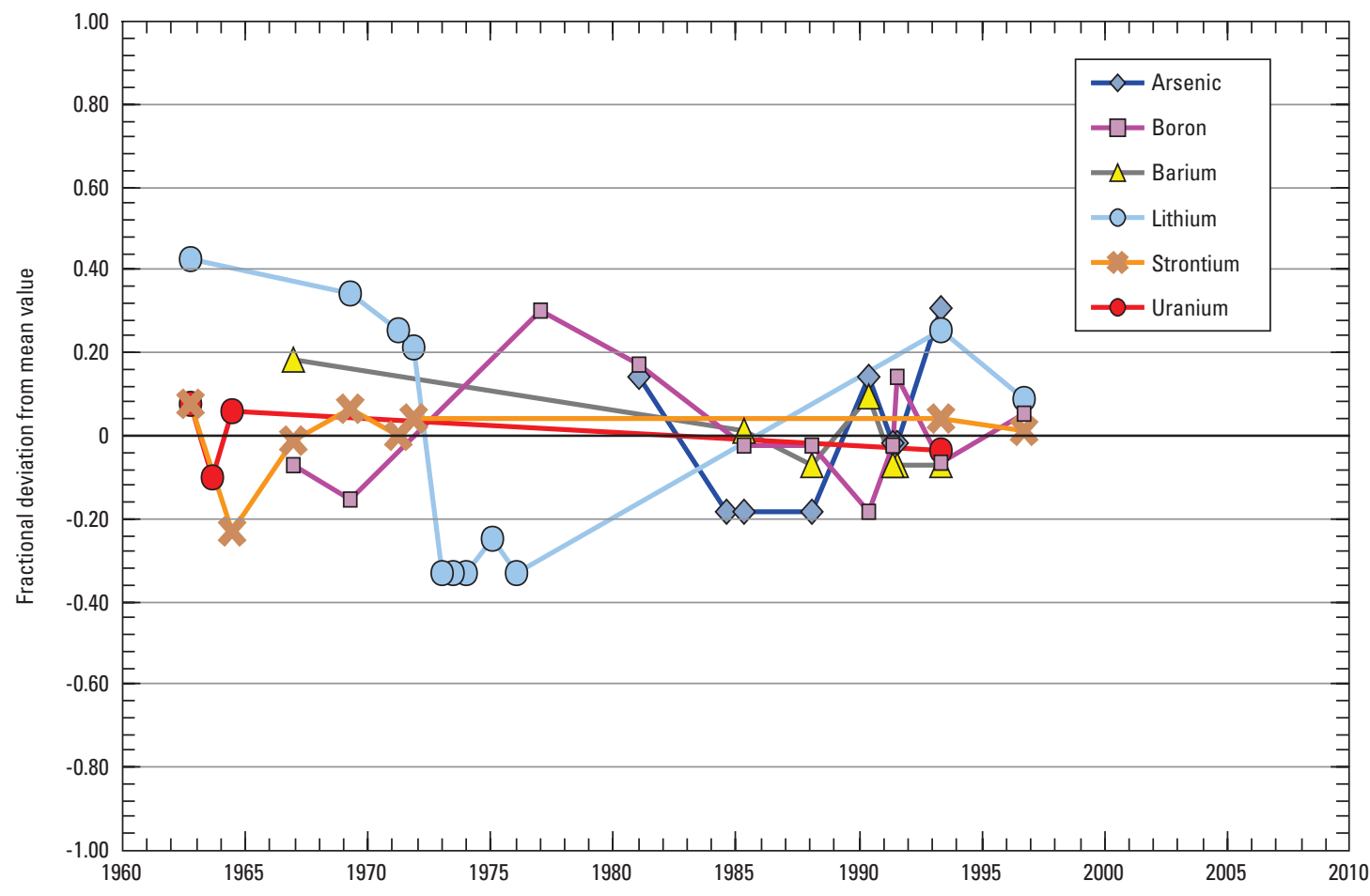

Figure 59. Deviation of selected trace element concentrations from mean values for water samples collected from WW-C-1, Nevada National Security Site, Nye County, Nevada. 


\section{Transient Effects of Pumping}

Evaluations of temporal changes in the chemical compositions of water pumped from NNSS supply wells indicate a range of responses for individual wells that may reflect a combination of aquifer dynamics and borehole construction or conditions. A number of the wells show remarkable temporal uniformity of compositions despite large volumes of water produced. Others show distinct shifts in composition with time. These shifts can be manifested as either progressive changes or more discrete steps.

Observed compositional shifts can be related to changes in pumping history of some, but not all, wells. Several mechanisms may explain the observed shifts. The most likely is that multiple water-bearing zones may be penetrated in a single well. If the different zones have distinct compositions, their relative contributions to the mixed water withdrawn from the well may change through time depending on aquifer hydraulics, pumping stresses, or borehole dynamics. Unfortunately, multiple producing intervals in water-supply wells have not been isolated and sampled separately. Consequently, end-member compositions for groundwater from any given zone are not known and estimates of mixing proportions cannot be made.

Several wells show distinct compositional differences between samples obtained during periods of continuous pumping and samples obtained by bailing from discrete depths years after pumping ceased. In these cases, bailed water typically has a lower specific conductance, indicating that water bailed from the well is more dilute relative to samples collected during periods of continuous pumping. Wells that produced water from the LCA in Yucca Flat commonly show this pattern indicating that groundwater containing higher dissolved solids and greater $\mathrm{HCO}_{3}$, $\mathrm{Ca}$, and $\mathrm{Mg}$ constituents was withdrawn from deeper, carbonate aquifers during periods of pumping. After pumping ceased, more dilute groundwater entered the well either from flow through shallower rock units or by leakage of surface water into the borehole through the annular space behind the casing. The presence of more dilute groundwater with volcanic-aquifer-like compositions has been identified at other boreholes that penetrated the LCA in Yucca Flat and has been attributed to semi-perching of water in shallower alluvial and volcanic units that drains downward into the underlying LCA (Farnham and others, 2005, p. 2-24).

Supply wells that showed no statistically significant changes in composition with time include well completions in boreholes on or near Pahute Mesa (U-20 WW, UE-19c WW, and WW-8) and Fortymile Wash (J-12 WW and J-13 WW) that are open to volcanic aquifers. Geochemical records for groundwater withdrawal from these wells range from 10 to 49 years and cumulative volumes of water withdrawal commonly are large (617-1,800 Mgal). These wells are open to a number of volcanic HSUs including the Paintbrush volcanic aquifer, Calico Hills zeolitized composite unit, Belted Range aquifer, and Pre-Belted Range composite unit. Most of these wells have simple constructions with water-producing zones restricted to a single HSU. The exception is J-13 WW, which has an upper and lower zone completed in two different HSUs with very different hydraulic properties. Nevertheless, most production is from the more transmissive Paintbrush volcanic-rock aquifer present in the upper zone, and only minor decreases in $\mathrm{HCO}_{3}, \mathrm{Ca}$, and $\mathrm{Mg}$ were identified over time (fig. 10).

Other supply wells that show little or no compositional variations with time are in southern Yucca Flat and Frenchman Flat. These include well completions in boreholes WW-3, WW-4, WW-4A, WW-5B, WW-C, and WW-C-1. Geochemical records for these wells range from 5 to 49 years, and cumulative volumes of water withdrawal range from 203 to 1,720 Mgal. WW-3 and WW-5B produce water from single completion intervals in the alluvial aquifer. Although groundwater pumped from WW-5B shows a small, but statistically significant difference in specific conductance between early and late samples, this difference is not reflected in variations of individual major ion constituents. WW-4 and WW-4A produce water from the Timber Mountain welded-tuff aquifer and Topopah Spring aquifer. Water samples from these two wells have not shown systematic shifts in chemical compositions despite a decrease in withdrawals from WW-4 by a factor of nearly 10 times after WW-4A was completed and began pumping continuously in 1994. However, concentrations of several individual constituents $\left(\mathrm{HCO}_{3}, \mathrm{Na}\right.$, $\mathrm{K}, \mathrm{Ca}$, and $\mathrm{F}$ ) show greater variability about mean values for samples collected after about 2001. The cause for the observed increase in variability is not known; however, it is interpreted as a real effect within the aquifer because concentrations of individual constituents analyzed for paired samples collected at similar times from both wells yielded similar results. Finally, water pumped from the lower carbonate aquifer in WW-C and WW-C-1 during a 41-year period show little or no significant systematic shifts in composition, despite pumping a total of approximately 2,420 Mgal from the two wells. Water from both wells have nearly identical compositions, which indicates that the LCA in this area can produce large quantities of chemically uniform water over sustained periods. 
Several wells may show the effects of gradual or sudden degradation of various well components (pumps, casing, grout) or changes in downhole well conditions. Notably, Army $1 \mathrm{WW}$ produced a large volume of compositionally uniform groundwater during 38 years of pumping through 2000; however, starting about this time, compositions became progressively more enriched in dissolved solids until pumping ceased in 2005. Besides a large increase in specific conductance, increases in the concentrations of $\mathrm{Cl}$ and most of the major cations were observed along with small decreases in $\mathrm{HCO}_{3}$. The onset of this shift in chemical behavior appears to be influenced by renewed pumping activity after a 5-year period of minimal production from 1995 to 2000. However, a similar chemical shift was not present in the early 1990s during a similarly large increase in withdrawal volumes, although pumping in the late 1980s did not approach zero as it did in the late 1990s (figs. 3 and 4). The shift in groundwater compositions throughout the 2000s may be related to physical and chemical degradation of downhole components during the period of inactivity; however, trace element concentrations reported for the May 29, 2003, sample from Army 1 WW do not show any substantial deviations from values obtained throughout the 1980s and 1990s (appendix C), including elements likely to be present in introduced materials (Ba, $\mathrm{Cr}, \mathrm{Mn}, \mathrm{Ni}, \mathrm{Pb}, \mathrm{Sr}, \mathrm{Zn}$ ). Alternatively, the distinct shift in $\mathrm{Cl}, \mathrm{Na}, \mathrm{Ca}, \mathrm{Mg}$, and $\mathrm{SiO}_{2}$ concentrations may be related to a progressive change in contributions from a stratified aquifer or aquifers tapped to different extents because of changing well dynamics or near-field hydraulic conditions related to pumping.

Supply wells showing small to moderate shifts in chemical composition with time are restricted to well completions in boreholes producing groundwater from alluvial and carbonate aquifers in Frenchmen Flat (UE-5c WW, WW-5A and WW-5C), and Yucca Flat (WW-A, UE-15d WW, UE-16d WW, and WW-2).

UE-5C WW produces water from the alluvial aquifer and shows a small but statistically distinct increase in specific conductance from 1971 to the 2000s that is associated with steady, low volume withdrawals. Statistically significant increases in $\mathrm{SO}_{4}$ and $\mathrm{SiO}_{2}$ and decreases in $\mathrm{Mg}$ are present over this same period, but other major ion concentrations did not show any systematic shifts. Notably, arsenic shows a 300 percent progressive increase in concentration from 1984 to 2003. Similar trends for other trace elements are not obvious, but only sporadic samples are available. Although most water is produced from the alluvial aquifer, the well is also open to the lower tuff confining unit. Small and progressively changing amounts of water from this zone may have contributed to the overall evolution of water withdrawn from this well.
WW-5A and WW-5C are separated by about $0.9 \mathrm{mi}$ and pump groundwater from single intervals completed in the alluvial aquifer. Groundwater compositions remained uniform in WW-5A from 1957 to 1964, which represents the central period of pumping from the well. However, significantly lower specific conductance and lower $\mathrm{Na}$ and $\mathrm{HCO}_{3}$ concentrations relative to values obtained from earlier samples when the well was pumping were measured in one sample collected in August 2000 (about 29 years after pumping ceased and 9 years after the well was reconditioned). Together, $\mathrm{Na}$ and $\mathrm{HCO}_{3}$ form the primary dissolved ion load and are consistent with the specific-conductance data, suggesting that groundwater in the well became more dilute after routine pumping ceased. The geochemical record for WW-5C is longer (1957-2005) and shows a statistically significant steplike change to higher specific conductance values between 1981 and 1985. Monotonic increases in $\mathrm{Na}, \mathrm{SO}_{4}$, and $\mathrm{F}$ concentrations are present and support the shift observed for specific conductance. Although other constituents do not show significant monotonic shifts in concentrations, $\mathrm{HCO}_{3}$, and to a lesser extent $\mathrm{Cl}$, fluctuate systematically about mean values in a manner that could be related to variations in the cumulative withdrawals from WW-5A, WW-5B, and WW-5C. Strong similarities between major ion concentrations, radiocarbon content, stable isotope compositions and most trace elements in groundwater pumped from adjacent wells WW-5A and WW-5C indicate the wells tap a similar water source within the alluvial aquifer. Pumping from WW-5B, about $1.8 \mathrm{mi}$ northwest of WW-5A, has produced compositionally uniform water during a long history of pumping; however, this water has distinct compositional differences relative to WW-5A and WW-5C. In some, but not all cases, concentrations from the spatially intermediate well, WW-5C, are intermediate between end member compositions in WW-5A and WW-5B. Although all three wells are in close proximity and produce water from the alluvial aquifer, compositional differences indicate that multiple heterogeneous sources are present over short lateral or vertical distances.

Groundwater pumped from the alluvial aquifer at WW-A from 1960 to 1988 shows no evidence of systematic shifts in composition; however, several major ion concentrations $\left(\mathrm{Cl}, \mathrm{SO}_{4}, \mathrm{~K}\right.$, and $\left.\mathrm{F}\right)$ show large amounts of scatter during this period. Bailed samples collected at discrete depths in the 2000s, more than 10 years after pumping ceased, are generally more dilute (lower mean specific conductance) and show a complex range of chemical responses for individual major-ion constituents. Systematic temporal variations in bailed samples collected from 1999 to 2005 indicate that water introduced into the shallow saturated zone in the alluvial aquifer was not quickly homogenized under nonpumping conditions. 
Chemical results for water samples pumped from the deep carbonate aquifer in UE-15d WW do not offer compelling evidence for systematic temporal changes throughout the period of pumping from the early 1960s through the early 1980s. However, specific conductance values may show a decreasing trend, especially if two of the most recent samples collected by bailing are included. Majorion concentrations for samples collected during periods of pumping show more scatter than results from other supply wells. Larger shifts in composition are observed in samples collected from UE-15d WW after pumping ceased in 1981. Most of these chemical changes are reflected as overall decreases in the two most abundant dissolved ions, $\mathrm{HCO}_{3}$ and $\mathrm{Na}$, especially if bailed samples collected in the early 1990s are considered. Pumping from UE-15d WW was greatest from about 1967 through 1972, which corresponds to samples having the highest specific conductance, $\mathrm{HCO}_{3}$, and $\mathrm{Na}$ concentrations, and lowest $\mathrm{SiO}_{2}$ concentrations. Like many other supply wells, water present in the well nearly a decade after pumping ceased is more dilute than groundwater sampled during periods of active pumping. The UE-15d WW borehole is very deep (6,001 feet below land surface) with a large open interval between 2,800 and 6,001 feet. Although units above about 5,300 ft are generally considered to be confining units, several permeable zones may provide access to groundwater above the carbonate aquifer present at the bottom of the well. It is likely that active pumping produced abundant water from the deep carbonate aquifer whereas more dilute water may have entered the well after pumping stopped in 1981.

Water pumped from the upper carbonate aquifer at UE-16d WW shows a slight decrease in specific conductance values for samples collected from 1981 to 2005. Concentrations of $\mathrm{HCO}_{3}, \mathrm{Na}, \mathrm{SiO}_{2}$, and $\mathrm{F}$ show slight decreases with time, whereas $\mathrm{Cl}$ appears to have increased slightly. In contrast, $\mathrm{Ca}, \mathrm{Mg}$, and $\mathrm{SO}_{4}$ remained relatively unchanged. Although these results imply that groundwater may have become more dilute with time, the differences are not large or compelling. Although the screened interval in UE-16d WW is limited (165 feet long and near the base of the upper carbonate aquifer), the annulus outside the casing is open and groundwater from other units higher in the well may have contributed more dilute water at different times. Available trace element and isotope data are consistent with, at most, only small changes occurring from 1977 to 1993.

The most compelling example of temporal chemical changes in a water-supply well is from WW-2. Water pumped from the lower carbonate aquifer shows a distinct 20 percent progressive increase in specific conductance from 1962 to 1991. Most major ions also show statistically significant increases in concentration during this period. Subsequent samples bailed from discrete depths 10 or more years after pumping ceased in 1990, deviate significantly from values obtained earlier. Most constituents in bailed samples shift to lower concentrations, except for $\mathrm{Cl}$, which is substantially higher in at least some of the bailed samples. After replacing the pump and purging the well in 2006, conductance and major ion concentrations in groundwater returned to values closer to those obtained during the original period of pumping. The well casing has two perforated zones which tap different dolomite layers within the lower carbonate aquifer (appendix E, fig. E-25). Groundwater within these two dolomites is presumably distinct, and the mixture withdrawn likely changed over time due to inherent hydraulic properties of the units. Once pumping ceased, more dilute, volcanic-like water entered the well either by downward leakage of water into the casing, or by recharge into the shallow carbonate units accessed through the upper perforated zone. As a result, bailed samples collected 10 to 15 years after pumping ceased yielded groundwater with dramatically different, and variable, compositions compared to groundwater obtained by pumping. The quality of bailed samples is reasonable (charge balances are within 10 percent of neutral), and the well had been adequately purged after construction by nearly three decades of pumping. After installation of a new pump in 2006, the well was purged sufficiently to extract most, but not all of the more dilute water recharged during the period of nonpumping. Continued pumping would likely produce groundwater dominated by the carbonate aquifer source with compositions similar to samples collected in the late 1980s and early 1990s.

\section{Conclusion}

A large amount of groundwater geochemical data have been collected from wells used to supply water for various activities at the Nevada National Security Site since the site was established in the 1950s. Data in this report represent groundwater samples from 23 well completions in 19 boreholes that cumulatively supplied nearly 20,000 million gallons of water. Analyses produced by a number of different laboratories had previously been compiled in a comprehensive database; however, no attempt had been made to screen the data set for spurious results or organize the analyses into a consistent set of units. In this report, available data are screened, tabulated, and evaluated for temporal trends that might be related to groundwater withdrawal histories presented in a companion report (Elliott and Moreo, 2011). 
Several different statistical indicators of monotonic trend were applied to data in this report, and include both parametric tests (least-squares linear regression and two-sample t-tests) and nonparametric tests (Mann-Kendall trend analysis, Sen's slope test, and Mann-Whitney rank-sum tests). The quality of the data collected over a substantial period of time by different laboratories without specific reference to quality control criteria presents a challenge for making these evaluations. Frequency of sampling is also less than ideal. Therefore, only the most reliable data were used to make statistical evaluations, including specific conductance and major-ion concentrations. Trace-metal and environmental isotope data were analyzed infrequently and are considered less reliable than major ions, especially for earlier samples. Nevertheless, these data are included and were used, where possible, to support the statistical evaluations based on major constituents. Because of issues related to data quality and sampling frequency, trend analysis is intended to detect significant monotonic shifts rather than short-term or cyclic variations. Correlations between chemical variations and groundwater withdrawal history are considered qualitative and were made by visual comparison rather than quantitative statistical analysis.

Geochemical responses to long-term pumping from water-supply wells show a variety of patterns. In most cases, concentrations are scattered within the range expected for analytical uncertainty and do not show evidence for unambiguous temporal trends during the history of active pumping. This includes wells where groundwater withdrawal rates may have changed dramatically over time. However, cessation of pumping in a number of wells commonly resulted in a distinct shift in chemistry in subsequent water samples, which typically were collected by bailing. This pattern commonly involved an overall shift toward lower specific conductance and major-ion concentrations, which indicate that more dilute water entered the wells after pumping stopped. It is unclear whether this type of response reflects leakage of surface water into the well casings, or represents more regional recharge of dilute water into the shallow phreatic zone. In one case (WW-2), replacement of a pump and re-initiation of pumping produced water with higher specific conductance and major-ion concentrations that approached values obtained from water samples collected during the main period of active pumping.

Wells that show systematic differences or long-term trends of compositional change during active pumping commonly have multiple intervals that are open to different lithostratigraphic or hydrostratigraphic zones, presumably containing water with different compositions. None of the wells with these types of completions have zones that were isolated and sampled separately. Therefore, end members contributing to mixed water within a single well cannot be characterized. Groundwater from wells having multiple open intervals is dominated by water from the zone with the highest permeability. However, contributions from other water-bearing units may influence the overall mixture differently at different times due to hydraulic conditions within the zones or dynamics in the well.

Data compiled and evaluated in this report indicate that many of the aquifers tapped by water-supply wells at the Nevada National Security Site are capable of producing large amounts of water with uniform compositions despite many years of pumping. In some wells, temporal shifts in compositions can be demonstrated. These changes should be relatable to hydraulic properties of the hydrostratigraphic units intersected and the dynamics of well construction and pumping. Frequent sampling and analysis of a comprehensive suite of chemical and isotopic constituents offer the best chances of understanding aquifer responses to pumping stresses.

\section{Acknowledgments}

This study was funded by the U.S. Department of Energy under Interagency Agreement DE-A152-07NA28100.

\section{References Cited}

Bechtel Nevada, 2002, A hydrostratigraphic model and alternatives for the groundwater flow and contaminant transport model of Corrective Action Units 101 and 102Central and western Pahute Mesa, Nye County, Nevada: U.S. Department of Energy DOE/NV/11718-706, 383 p.

Bechtel Nevada, 2005, A hydrostratigraphic framework model and alternatives for the groundwater flow and contaminant transport model of corrective action unit 98-Frenchman Flat, Clark, Lincoln and Nye Counties, Nevada: U.S. Department of Energy DOE/NV/11718-1064, 240 p.

Bechtel Nevada, 2006, A hydrostratigraphic model and alternatives for the groundwater flow and contaminant transport model of Corrective Action Unit 97-Yucca FlatClimax Mine, Lincoln and Nye Counties, Nevada: U.S. Department of Energy DOE/NV/11718-1119, 288 p.

Blankennagel, R.K., 1968, Geophysical logging and hydraulic testing, Pahute Mesa, Nevada Test Site: Groundwater, v.6, no. 4, p. 24-31.

Bullen, T.D., and Kendall, Carol, 1998, Tracing of weathering reactions and water flowpaths-A multi-isotope approach in Kendall, Carol and McDonnell, J.J., eds., Isotope Tracers in Catchment Hydrology, Elsevier Science, Amsterdam, p. 611-646. 
Claassen, H.C., 1973, Water quality and physical characteristics of Nevada Test Site water-supply wells: U.S. Geological Survey Report USGS-474-158 [NTS-242], 145 p. [Available only from National Technical Information Service, U.S. Department of Commerce, Alexandria, Virginia 22312.]

D’Agnese, F.A., O’Brien, G.M., Faunt, C.C., Belcher, W.R., and San Juan, Carma, 2002, A three-dimensional numerical model of predevelopment conditions in the Death Valley regional ground-water flow system, Nevada and California: U.S. Geological Survey Water-Resources Investigations Report 02-4102, 114 p.

Dinwiddie, G.A., and Weir, J.E., Jr., 1979, Summary of hydraulic tests and hydrologic data for holes UE16d and UE16f, Syncline Ridge area, Nevada Test Site: U.S. Geological Survey Report USGS-1543-3, 25 p.

Elliott, P.E., and Moreo, M.T., 2011, Groundwater withdrawals and associated well descriptions for the Nevada National Security Site, Nye County, Nevada, 1951-2008: U.S. Geological Survey Data Series 567, 126 p., accessed April 10, 2012, at http://pubs.usgs.gov/ds/567/pdf/ds567.pdf.

Farnham, I.M., Rose, T.P., Kwicklis, E.M, Hershey, R.L., Paces, J.B., and Fryer, W.M., 2005, Geochemical and isotopic evaluation of groundwater movement in Corrective Action Unit 97-Yucca Flat/Climax Mine, Nevada Test Site, Nevada: Stoller-Navarro Joint Venture SN $\backslash 99205$ 070 [variously paged], accessed April 10, 2012, at http:// www.osti.gov/energycitations/servlets/purl/877252NKdprN/877252.pdf.

Faunt, C.C., Sweetkind, D.S., and Belcher, W.R., 2004, Threedimensional hydrogeologic framework model, in Belcher, W.R., ed., Chapter E of Death Valley regional ground-water flow system, Nevada and California-Hydrogeologic framework and transient ground-water flow model: U.S. Geological Survey Scientific Investigations Report 20045205, p. 165-256.

Fenelon, J.M., Sweetkind, D.S., and Laczniak, R.J., 2010, Groundwater flow systems at the Nevada Test Site, Nevada-A synthesis of potentiometric contours, hydrostratigraphy, and geologic structures: U.S. Geological Survey Professional Paper 1771, 54 p., 6 pls.

Garber, M.S., and Thordarson, William, 1962, Ground water test well C, Nevada Test Site, Nye County, Nevada: U.S. Geological Survey Open-File Report 62-50, 79 p.

Gibbons, R.D., 1994, Statistical methods for groundwater monitoring: New York, John Wiley \& Sons, Ltd., 289 p.

Gilbert, R.O., 1987, Statistical methods for environmental pollution monitoring: New York, John Wiley \& Sons, Ltd., $321 \mathrm{p}$.
Gillespie, David, Donithan, Dee, and Seaber, Paul, 1996, Nevada Test Site water-supply wells: Desert Research Institute Publication 45138, 68 p.

Gonzalez, D.A., 1989, Onsite environmental report for the Nevada Test Site, January 1988-December 1988: U.S. Department of Energy Report DOE/NV/10630-8, 234 p.

Helsel, D.R., and Hirsch R.M., 2002, Statistical methods in water resources techniques of water resources investigations, Book 4, Chapter A3, U.S. Geological Survey, 522 p., accessed April 10, 2012, at http://pubs.usgs. gov/twri/twri4a3/.

Hershey, R.L., Thomas, J.M., Rose, T.P., Paces, J.B., Farnham, I.M., and Benedict F.C., Jr., 2005, Evaluation of groundwater movement in the Frenchman Flat CAU using geochemical and isotopic analysis: Desert Research Institute Publication 45207, DOE/NV/13609-36, 65 p. plus 2 app.

Hershey, R.L., Paces, J.B., Singleton, M.J., Kwicklis, E.M., Decker, D.L., Fryer, W.M., Earman, Sam, 2008, Geochemical and isotopic evaluation of groundwater movement in Corrective Action Unit 99: Rainier Mesa and Shoshone Mountain, Nevada Test Site, Desert Research Institute Publication 45229, [variously paged].

Hood, J.W., 1961, Water wells in Frenchman and Yucca Valleys, Nevada Test Site, Nye County, Nevada: U.S. Geological Survey Open-File Report 61-68, 60 p.

Johnson, T.M., Roback, R.C., McLing, T.L., Bullen, T.D., DePaolo, D.J., Doughty, Christine, Hunt, R.J., Smith, R.W., Cecil, L.D., and Murrell, M.T., 2000, Groundwater "fast paths" in the Snake River Plain aquifer-Radiogenic isotope ratios as natural groundwater tracers: Geology, v. 28, p. 871-874.

Laczniak, R.J., Cole, J.C., Sawyer, D.A., and Trudeau, D.A., 1996, Summary of hydrogeologic controls on groundwater flow at the Nevada Test Site, Nye County, Nevada: U.S. Geological Survey Water-Resources Investigations Report 96-4109, 59 p., accessed April 10, 2012, at http:// pubs.usgs.gov/wri/wri964109/.

Ludwig, K.R., 2003, User's Manual for IsoPlot/Ex 3.00-A geochronological toolkit for Microsoft Excel: Berkeley Geochronology Center Special Publication, No. 4, 73 p.

Lyles, B.F, 1990, Tritium variations in groundwater on the Nevada Test Site: Desert Research Institute, Water Resources Center Publication 45086, DOE/NV/10384-38, $85 \mathrm{p}$.

Lyles, B.F., 1993, Tritium activities in selected wells on the Nevada Test Site: Desert Research Institute, Water Resources Center Publication 45104, DOE/NV/1084520 UC-703, 16 p., accessed April 10, 2012, at http:// www.osti.gov/bridge/servlets/purl/10105866-gSVO2p/ native/10105866.pdf. 
Minitab Inc., 2007, Minitab ${ }^{\circledR} 15-$ Statistical software, version 15.1: Minitab Inc., State College, Pennsylvania.

Moore, J.E., 1961, Records of wells, test holes, and springs in the Nevada Test Site and surrounding area: U.S. Geological Survey Open-File Report 61-106, 22 p.

Moore, J.E., 1962, Selected logs and drilling records of wells and test holes drilled at the Nevada Test Site prior to 1960: U.S. Geological Survey Open-File Report 62-87, 54 p.

Moore, J.E., Doyle, A.C., Walker, G.E., and Young, R.A., 1963, Ground water Test Well 2, Nevada Test Site, Nye County, Nevada: U.S. Geological Survey Open-File Report 63-101, 73 p.

National Security Technologies, LLC, 2007, A hydrostratigraphic model and alternatives for the groundwater flow and contaminant transport model of Corrective Action Unit 99-Rainier Mesa-Shoshone Mountain, Nye County, Nevada: U.S. Department of Energy DOE/NV/25946-146, 302 p., accessed April 10, 2012, at http://www.osti.gov/bridge/servlets/purl/934454Shw2Uk/934454.pdf.

Osterkamp, W.R., Lane, L.J., and Savard, C.S., 1994, Recharge estimates using a geomorphic/distributedparameter simulation approach, Amargosa River Basin: Water Resources Bulletin, v. 30, p. 493-507.

Paces, J.B., Ludwig, K.R., Peterman, Z.E., and Neymark, L.A., 2002, ${ }^{234} \mathrm{U} /{ }^{238} \mathrm{U}$ evidence for local recharge and patterns of ground-water flow in the vicinity of Yucca Mountain, Nevada, USA: Applied Geochemistry, v. 17, p. 751-779.

Perfect, D.L., Faunt, C.C., Steinkampf, W.C., and Turner, A.K., 1995, Hydrochemical data base for the Death Valley region, California and Nevada: U.S. Geological Survey Open-File Report 94-305, 10 p. and 2 diskettes, accessed April 10, 2012, at http://pubs.usgs.gov/of/1994/0305/report. pdf.

Peterman, Z.E., Stuckless, J.S., Mahan, S.A., Marshall, B.D., Guentag E.D., and Downey, J.S., 1992, Strontium isotope characterization of the Ash Meadows ground-water system, southern Nevada, USA, in Kharaka, Y.K., and Maest, A.S., eds., Water-rock interaction: Proceedings of the Seventh International Symposium on Water-Rock Interaction, A.A. Balkema Publishers, Rotterdam, p. 825-829.

Piper, A.M., 1944, A graphic procedure in the geochemical interpretation of water analyses: American Geophysical Union, Transactions, v. 25, p. 914-923.
Rose, T.P., Benedict, Jr., F.C., Thomas, J.M., Sicke, W.S., Hershey, R.L., Paces, J.B., Farnham, I.M., and Peterman, Z.E., 2006, Geochemical data analysis and interpretation of the Pahute Mesa - Oasis Valley groundwater flow system, Nye County, Nevada, August 2002: Lawrence Livermore National Laboratory Report UCRL-TR-224559 [variously paged].

Russell, C.E., 1989, Assessment of the Nevada Test Site monitoring well system: Desert Research Institute Publication 45072, 46 p.

Savard, C.S., 1998, Estimated ground-water recharge from streamflow in Fortymile Wash near Yucca Mountain, Nevada: U.S. Geological Survey Water-Resources Investigation Report 97-4273, 30 p., accessed April 10, 2012, at http://pubs.usgs.gov/wri/1997/4273/report.pdf.

Schlumberger Water Services, 2010, AquaChem ${ }^{\circledR}$-Statistical software, version 2010.1: Schlumberger Water Services, Waterloo, Ontario.

Sen, P.K., 1968, Estimates of the regression coefficient based on Kendall's tau: Journal of the American Statistical Association, v. 63, p. 1379-1389.

Stoller-Navarro Joint Venture, 2008, Geochem08.mdb and a user's guide to the comprehensive water quality database for groundwater in the vicinity of the Nevada Test Site: Stoller-Navarro Joint Venture S-N/99205-059, Revision 3 [CD-ROM; variously paged].

Sweetkind, D.S., Belcher, W.R., Faunt, C.C., and Potter, C.J., 2004, Geology and hydrogeology, in Belcher, W.R., ed., Chapter B of Death Valley regional ground-water flow system, Nevada and California-Hydrogeologic framework and transient ground-water flow model: U.S. Geological Survey Scientific Investigations Report 2004-5205, p. 21-98, accessed April 10, 2012, at http://pubs.usgs.gov/ sir/2004/5205/pdf/Chapter B.pdf.

Thordarson, William, 1983, Geohydrologic data and test results from well J-13, Nevada Test Site, Nye County, Nevada: U.S. Geological Survey Water-Resources Investigations Report 83-4171, 63 p., accessed April 10, 2012, at http://pubs.usgs.gov/wri/1983/4171/report.pdf.

Thordarson, William, Young, R.A., and Winograd, I.J., 1967, Records of wells and test holes in the Nevada Test Site and vicinity (through December 1966): U.S. Geological OpenFile Report 67-218, 26 p., accessed April 10, 2012, at http:// pubs.usgs.gov/of/1967/0218/report.pdf.

Titterington, D.M., and Halliday, A.N., 1979, On the fitting of parallel isochrons and the method of maximum likelihood: Chemical Geology, v. 26, p. 183-195. 
U.S. Department of Energy, 1996a, Recompletion report and summary of well history for Water Well 2: U.S. Department of Energy Nevada Operations Office Environmental Restoration Division DOE/NV-436 UC-700 [variously paged].

U.S. Department of Energy, 1996b, Recompletion report and summary of well history for Water Well 3: U.S. Department of Energy Nevada Operations Office Environmental Restoration Division DOE/NV-433 UC-700 [variously paged].

U.S. Department of Energy, 2004, EPA Farm: U.S. Department of Energy, National Nuclear Security Administration Nevada Site Office Report DOE/NV-771, 2 p.

U.S. Department of Energy, 2005, Nevada Test Site guide: U.S. Department of Energy, National Nuclear Security Administration Nevada Site Office DOE/NV-715, rev. 1, 81 p.

U.S. Department of Energy, 2008, Groundwater protection program plan for the National Nuclear Security Administration Nevada Site Office: U.S. Department of Energy, National Nuclear Security Administration Nevada Site Office DOE/NV/25946-557 [variously paged].

U.S. Department of Energy, 2009, Understanding groundwater at the Nevada Test Site: U.S. Department of Energy Report DOE/NV-915, rev. 3, 2 p.

Waddell, R.K., Robison, J.H., and Blankennagel, R.K., 1984. Hydrology of Yucca Mountain and vicinity, NevadaCalifornia-Investigative results through mid-1983: U.S. Geological Survey Water Resources Investigations Report 84-4267, 72 p., accessed April 10, 2012, at http://pubs.usgs. gov/wri/1984/4267/report.pdf.

Warren, R.G., Sawyer, D.A., Byers, F.M., Jr., and Cole, G.L., 2003, A petrographic, geochemical, and geophysical database, and stratigraphic framework for the southwestern Nevada volcanic field: Los Alamos National Laboratory Report LA-UR-03-1503, 55 p., accessed April 10, 2012, at http://www.pggdb-swnvf.lanl.gov/.
Wild, C.J. and Seber, G.A., 1999, Chance encounters-A first course in data analysis and inference: New York, John Wiley \& Sons, Ltd., 632 p.

Wills, C.A., 2006, Nevada Test Site environmental report 2005: National Security Technologies, LLC, Report DOE/ NV/11718-1214, prepared for the U.S. Department of Energy, National Nuclear Security Administration, Nevada Site Office, [variously paged].

Winograd, I.J., and Thordarson, William, 1975, Hydrogeologic and hydrochemical framework, south-central Great Basin, Nevada-California; with special reference to the Nevada Test Site: U.S. Geological Survey Professional Paper 712-C, 126 p., accessed April 10, 2012, at http://pubs.usgs.gov/ pp/0712c/report.pdf.

Wood, D.B., 2007, Digitally available interval-specific rocksample data compiled from historical records, Nevada Test Site and vicinity, Nye County, Nevada: U.S. Geological Survey Data Series Report 297, rev. 2.0, 58 p., accessed April 10, 2012, at http://pubs.usgs.gov/ds/2007/297/.

Wood, D.B., and Reiner, S.R., 1996, Ground-water data for 1990-91 and ground-water withdrawals for 1951-91, Nevada Test Site and vicinity, Nye County, Nevada: U.S. Geological Survey Open-File Report 96-475, 78 p., accessed April 10, 2012, at http://pubs.usgs.gov/ of/1996/0475/report.pdf.

York, Derek, 1969, Least-squares fitting of a straight line with correlated errors: Earth and Planetary Science Letters, v. 5, p. 320-324.

Young, R.A., 1972, Water supply for the Nuclear Rocket Development Station at the U.S. Atomic Energy Commission's Nevada Test Site: U.S. Geological Survey Water-Supply Paper 1938, 19 p., accessed April 10, 2012, at http://pubs.usgs.gov/wsp/1938/report.pdf. 


\section{Appendix A. pH and Specific Conductance Data for Water from Supply Wells at the Nevada National Security Site, Nye County, Nevada, 1951-2008}

Concentration of hydrogen ions $(\mathrm{pH})$ and specific conductance measurements for groundwater samples collected from water-supply wells on the Nevada National Security Site (NNSS) are presented in a Microsoft ${ }^{\circledR}$ Excel spreadsheet. This spreadsheet is derived from data extracted from the UGTA water quality database (Geochem08.mdb) maintained in Microsoft ${ }^{\circledR}$ Access and administered by the U.S. Department of Energy's primary contractor (currently Navarro-Intera, LLC). Data are listed sequentially by date for each well (" $\mathrm{pH}$ and SC" sheet in the Excel ${ }^{\circledR}$ spreadsheet), and can be sorted by well name from the pull-down menu at the top of the second column header. Locations of the wells are shown on a map of the NNSS. Data are available for download at http://pubs.usgs/ gov/sir/2012/5023/.

\section{Appendix B. Major Ion Concentration Data for Water from Supply Wells at the Nevada National Security Site, Nye County, Nevada, 1951-2008}

Concentrations of major ions ( $\mathrm{Na}, \mathrm{K}, \mathrm{Ca}, \mathrm{Mg}, \mathrm{SiO}_{2}$, bicarbonate alkalinity as $\mathrm{HCO}_{3}$, carbonate alkalinity as $\mathrm{CO}_{3}$, total alkalinity as $\mathrm{HCO}_{3}, \mathrm{Cl}, \mathrm{SO}_{4}, \mathrm{NO}_{3}, \mathrm{~F}, \mathrm{Br}$, and $\mathrm{PO}_{4}$ ) for groundwater samples collected from water-supply wells on the Nevada National Security Site (NNSS) are presented in a Microsoft ${ }^{\circledR}$ Excel spreadsheet. This spreadsheet is derived from data extracted from the UGTA water-quality database (Geochem08.mdb) maintained in Microsoft ${ }^{\circledR}$ Access and administered by the U.S. Department of Energy's primary contractor (currently Navarro-Intera, LLC). Data are listed sequentially by date for each well ("TableMajors" sheet in the Excel ${ }^{\circledR}$ spreadsheet), and can be sorted by well name from the pull-down menu at the top of the second column header. Locations of the wells are shown on a map of the NNSS as are time-series plots of the most abundant major ions. All concentrations are given as milligrams of solute per liter of water (mg/L; equivalent to parts per million). Total dissolved solids (TDS) is the sum of all individual solutes for that sample.

Ionic charge balances greater than 10 percent caused by one or more missing value are indicated by shaded rows. Comments, indicated by red triangles in the upper right-hand corner of a cell, give the original value reported in Geochem08.mdb that was (1) considered spurious compared to values from other samples, (2) considered a typographical error (for example, decimal misplaced), or (3) a list of the individual values used to calculate an average reported for a single sample date. Data are available for download at http:// pubs.usgs/gov/sir/2012/5023/. 


\section{Appendix C. Trace Element Concentration and Environmental Isotope Data for Water From Supply Wells at the Nevada National Security Site, Nye County, Nevada, 1951-2008}

Concentrations of trace elements (As, B, Ba, Be, Cd, $\mathrm{Co}, \mathrm{Cr}, \mathrm{Fe}, \mathrm{Hg}, \mathrm{Li}, \mathrm{Mn}, \mathrm{Mo}, \mathrm{Ni}, \mathrm{Pb}, \mathrm{Rb}, \mathrm{Sb}, \mathrm{Se}, \mathrm{Sr}, \mathrm{U}, \mathrm{V}$, and $\mathrm{Zn})$ and environmental isotopes $\left(\delta^{2} \mathrm{H}, \delta^{18} \mathrm{O}, \delta^{13} \mathrm{C},{ }^{14} \mathrm{C},{ }^{36} \mathrm{Cl} /\right.$ $\mathrm{Cl},{ }^{87} \mathrm{Sr} /{ }^{86} \mathrm{Sr}$, and ${ }^{234} \mathrm{U} / 238 \mathrm{U} \mathrm{AR}$ ) for groundwater samples from water-supply wells on the Nevada National Security Site (NNSS) are presented in a Microsoft ${ }^{\circledR}$ Excel spreadsheet. This spreadsheet is derived from data extracted from the UGTA water quality database (Geochem08.mdb) maintained in Microsoft ${ }^{\circledR}$ Access and administered by the U.S. Department of Energy's primary contractor (currently Navarro-Intera, LLC). Data are listed sequentially by date for each well ("TraceElements_Isotopes" sheet in the Excel ${ }^{\circledR}$ spreadsheet), and can be sorted by well name from the pull-down menu at the top of the second column header. All concentrations are given as micrograms of solute per liter of water $(\mu \mathrm{g} / \mathrm{L}$; equivalent to parts per billion). Values for $\delta^{2} \mathrm{H}, \delta^{18} \mathrm{O}$, and $\delta^{13} \mathrm{C}$ are given as per mil (\%) deviation from a standard value as defined in the Conversion Factors, Datums, Isotope Notation Conventions, Units of Concentration, and Abbreviations and Acronyms section in this report. Radiocarbon analyses $\left({ }^{14} \mathrm{C}\right)$ are given as concentrations relative to the amount present in the modern (pre-bomb) atmosphere (percent modern carbon, or pmc). Values for ${ }^{36} \mathrm{Cl} / \mathrm{Cl}$ and ${ }^{87} \mathrm{Sr} /{ }^{86} \mathrm{Sr}$ are given as atomic ratios where ${ }^{36} \mathrm{Cl} / \mathrm{Cl}$ is equivalent to ${ }^{36} \mathrm{Cl} /\left({ }^{35} \mathrm{Cl}+{ }^{37} \mathrm{Cl}\right)$. Values for ${ }^{234} \mathrm{U} / 238 \mathrm{U}$ are given as activity ratios (AR), which are equal to the atomic ${ }^{234} \mathrm{U} /{ }^{238} \mathrm{U}$ ratio multiplied by the ratio of the decay constants for ${ }^{234} \mathrm{U}\left(\lambda_{234}=2.8262 \times 10^{-6}\right.$ year $\left.^{-1}\right)$ and ${ }^{238} \mathrm{U}\left(\lambda_{238}=1.55125 \times 10^{-10}\right.$ year $\left.^{-1}\right)$.

Concentrations analyzed, but determined to be less than detection limits are designated by a " $<$ " symbol along with the numerical value for the detection limits where known, or as "ND" for not detected where detection limits are not known. Comments, indicated by red triangles in the upper right-hand corner of a cell, give the original value reported in Geochem08.mdb that was (1) considered spurious compared to values from other samples, (2) considered to be a typographical error (for example, decimal misplaced), or (3) a list of the individual values used to calculate an average reported for a single sample date.

Data are available for download at http://pubs.usgs/gov/ sir/2012/5023/. 


\section{Appendix D. Results of Normality Tests and Trend Analyses}

Results of statistical tests of normality and trend based on available conductance and major ion concentrations from water-supply wells on the Nevada National Security Site (NNSS) are presented in a series of worksheets in a Microsoft ${ }^{\circledR}$ Excel workbook. Tests were performed using commercial software (Minitab ${ }^{\circledR}$ v.15.1.30 and AquaChem ${ }^{\circledR}$ v.2010.1.83). Results given for different normality tests are shown as either "passed" or "failed" depending on whether resulting p-values were greater than or less than, respectively, the critical value of 0.05 corresponding to the 95 -percent confidence limit. Different tests for normality emphasize different statistical aspects of a sample set and do not always return the same results.

The Mann-Kendall test is a nonparametric estimator of trend (Gilbert, 1987; Gibbons, 1994; Helsel and Hirsch, 2002). Two values, $S$ and $Z$, are computed by the procedure and are listed in appendix $\mathrm{D}$. The $\mathrm{S}$ value represents the number of times that the differences in a time-ranked sequence of values are greater than (1), less than ( -1$)$, or equal to (0) zero. Positive $\mathrm{S}$ values indicate possible increasing trends and negative $S$ values indicate possible decreasing trends with time. The $\mathrm{Z}$ statistic represents an estimate of the variance of $\mathrm{S}$, which is used to compute the standard normal cumulative distribution probability (Prob \%) for each constituent. A probability less than 5.00 percent allows the null hypothesis (there is no trend with time) to be rejected, and the sign of the $\mathrm{S}$ statistic determines if the trend is increasing or decreasing.

Sen's nonparametric estimator of slope computes the median of all concentration-compared-to-time data pairs (Gilbert, 1987). This value is given as the Slope in the tables of appendix D. Variances for these multiple slopes are used to establish upper and lower limits of confidence for the specified probability level (95 percent). Trend results are reported as significant if the confidence intervals are both positive or both negative numbers, and an increasing or decreasing trend, respectively, is reported.

Linear regression results are calculated using two parametric methods. The first test uses simple linear regression and calculates (1) the coefficient of variation $\left(R^{2}\right)$, which is an estimate of the degree of covariation between concentration and time ( 1 = perfect correlation, $0=$ zero correlation) and (2) the p-value representing the appropriateness of rejecting the null hypothesis of no trend with time. If p-values are less than 0.05 , then there is a 95 percent probability that data indicate an increasing or decreasing trend, depending on the sign of the slope. The validity of linear regression results depends on whether or not the regression residuals are normally distributed. This result is given in appendix D as either "passed" or "failed" and uses the Anderson-Darling test for normality.

The second linear regression test uses 2-error regression models (Ludwig, 2003) that consider uncertainty in the $X$ and $\mathrm{Y}$ values using the limits specified for analytical error. These models produce a best-fit slope and 95 percent uncertainty value. If the \pm 95 percent value exceeds the slope value, the null hypothesis is accepted (no trend). If the slope value exceeds the 95 percent value, an increasing or decreasing trend is indicated depending on the sign of the slope. The "Result" column is an overall evaluation of trend considering the criteria given by the p-value, residual normality, and \pm 95 percent slope estimator, and is unqueried if all outcomes are definitive and queried if one of the criteria does not yield a definitive outcome.

Data are available for download at http://pubs.usgs/gov/ $\underline{\operatorname{sir} / 2012 / 5023 / .}$. 


\section{Appendix E. Supporting Information}

Supporting information provided for each supply well includes three graphics with the following information:

1. A vertical profile for each borehole depicting hydrostratigraphic units, lithostratigraphic descriptions, and well construction details,

2. A plot of annual groundwater withdrawals for the period that water was produced,

3. A trilinear plot of major ion constituents (Piper diagram), and

Data are available for download at http://pubs.usgs/gov/sir/2012/5023/.

\section{Appendix F. Median and Mean Concentrations for Major lons in Water from Supply Wells at the Nevada National Security Site, Nye County, Nevada}

Median and mean concentrations for major ions ( $\mathrm{Na}, \mathrm{K}$, Ca, $\mathrm{Mg}, \mathrm{SiO}_{2}$, total alkalinity as $\mathrm{HCO}_{3}, \mathrm{Cl}, \mathrm{SO}_{4}, \mathrm{NO}_{3}$, and $\mathrm{F})$ calculated from data listed in appendix $\mathrm{B}$ are presented in a Microsoft ${ }^{\circledR}$ Excel spreadsheet along with standard deviation (Std Dev), standard error (Std Error) and number of samples included in the calculation ("Median_Mean" sheet in the Excel ${ }^{\circledR}$ spreadsheet). Mean values are shown as solid horizontal lines on plots of major ion concentration included for each well in the Well Descriptions section along with data used to calculate the statistics (filled symbols). Spurious analyses (open symbols) or data outside of the period of record were not included in calculations.

Data are available for download at http://pubs.usgs/gov/ sir/2012/5023/. 
Publishing support provided by the U.S. Geological Survey

Publishing Network, Tacoma Publishing Service Center

For more information concerning the research in this report, contact the Director, Nevada Water Science Center

U.S. Geological Survey

2730 N. Deer Run Road

Carson City, Nevada 89701

http://nevada.usgs.gov/ 
